C. 2

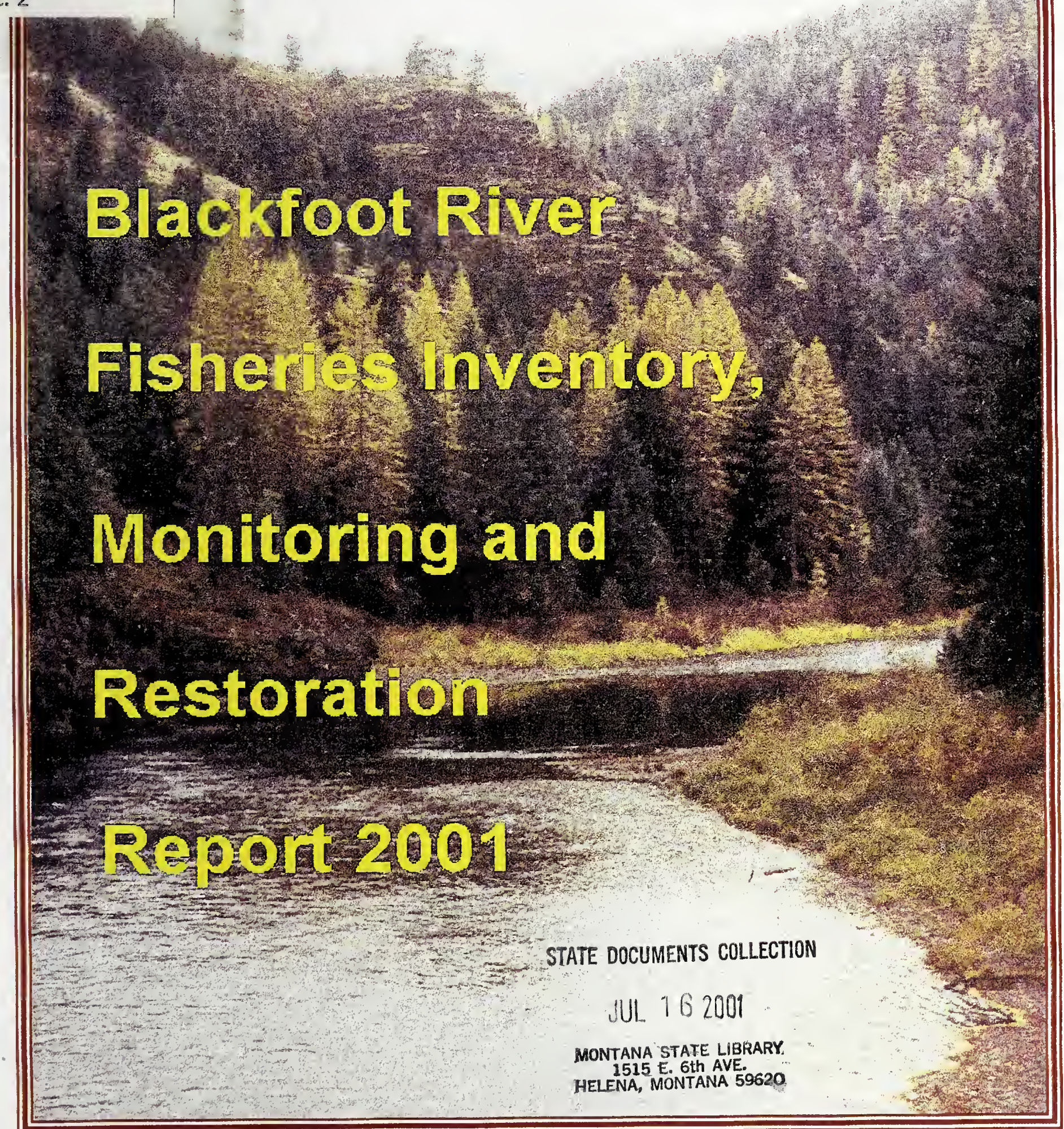

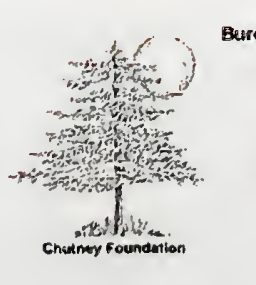
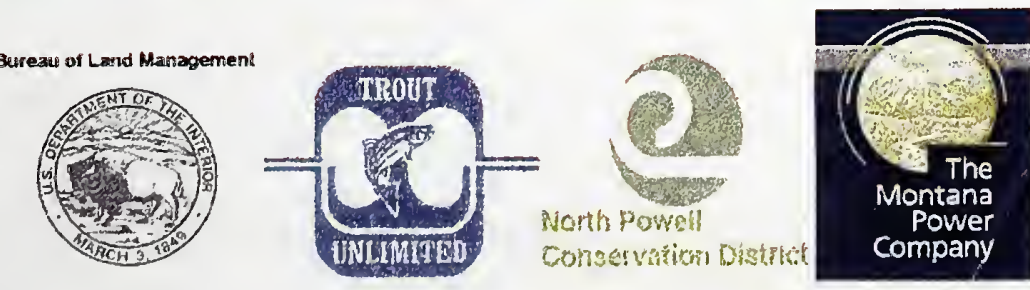

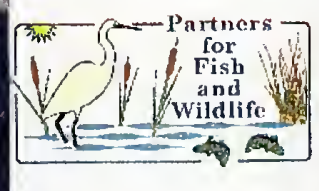


601 252002

APR 192004

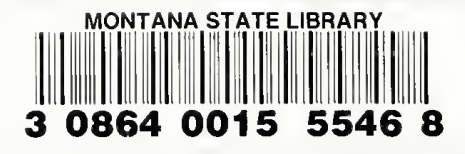




\title{
Blackfoot River Fisheries Inventory, Monitoring and Restoration Report 2001
}

\author{
by \\ Ron Pierce, Craig Podner and Jim McFee
}

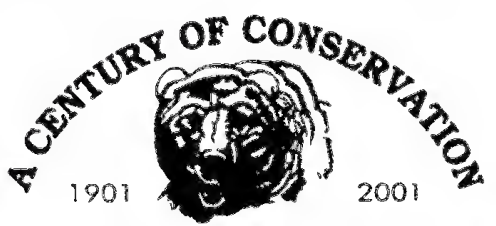

Montana Fish, Wildlife and Parks

3201 Spurgin Road

Missoula, Montana 59804

February 2001 


\section{Abstract}

We completed a two-year assessment for streams outside of the restoration focus area. These assessments began in 1999 with fish population inventories for 13 Blackfoot River tributaries upstream of Nevada Creek. In 2000, we expanded fish population inventories and problem identification to 22 Blackfoot River tributaries originating in the Garnet Mountain Range, with emphasis on the Union Creek and Nevada Creek watersheds. We found westslope cutthroat trout (Onchorynchus clarki lewisi) widely distributed in headwater reaches, but absent or in much lower densities in lower reaches of most tributaries. Lower densities in downstream reaches reflect habitat modifications and relate primarily to agricultural activities along the foothills of the Garnet Mountains. Bull trout (Salvelinus confluentus) were sampled in only two Garnet Mountain streams. We found non-native species in low numbers, except in lower stream reaches of some Garnet Mountain streams. We identified restoration opportunities throughout the foothills of the Garnet Mountains on all sampled streams.

In addition to these investigations, we completed restoration projects on 10 streams, fish population monitoring on 16 project streams and spring population estimates on the Blackfoot River. Trout densities continued to increase in Blackfoot River. Juvenile densities declined in many streams following the summer drought period. However, we also found density increases in several recently restored streams from 1999 through 2000 despite the summer drought. We completed special studies on the effectiveness of fish ladders and fish screens and found these structures capable of meeting project objectives. We completed riparian health inventories on the North Fork, assessed stream habitat in the upper Blackfoot River watershed, and identified restoration opportunities in both areas. In 2000, recreational conflict/native species recovery areas were identified in order to address growing recreational impact concerns in important bull trout areas. Early results for the 2000 whirling disease investigations showed infections expanding in tributaries to the lower and middle Blackfoot River. 


\section{Table of Contents}

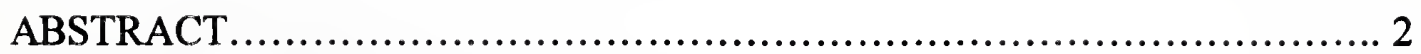

TABLE OF CONTENTS........................................................... 3

EXECUTIVE SUMMARY........................................................ 5

Bull Trout Recovery ............................................... 7

Westslope Cutthroat Trout Recovery..................................... 10

INTRODUCTION......................................................... 13

Study Area......................................................... 14

PROCEDURES

Working with Private Landowners: the key to successful restoration ........18

Fish Population Investigations............................................... 19

Bull Trout Redd Surveys..............................................19

Whirling Disease Sentinel Cage Studies Investigations................... 20

Westslope cutthroat trout Genetic Investigations........................ 20

Stream Temperatures.............................................. 20

North Fork Blackfoot River Riparian Inventories.........................21

Habitat Surveys in the Upper Blackfoot River and Landers Fork............21

RESULTS/DISCUSSION

PART I: Blackfoot River environment...........................................23

Blackfoot River Discharge.............................................23

Blackfoot River Temperatures ..........................................23

Blackfoot River Trout Populations

Johnsrud Section............................................... 24

Scotty Brown Bridge Section......................................25

PART II: Fisheries Population Inventories in Garnet Mountain Tributaries.........27

Union Creek ..........................................................28

Game Creek.....................................................29

Camas Creek....................................................30

Ashby Creek..............................................31

Arkansas Creek...................................... 32

Washoe Creek..........................................................33

Nevada Creek..........................................................34

Douglas Creek....................................................35

Cottonwood Creek........................................... 37

Chimney Creek................................................. 38

Murray Creek.................................................39

Sturgeon Creek.............................................. 40

Sheep Creek.......................................... 41

Black Bear Creek......................................42

Wasson Creek.................................................... 42

Wilson Creek..................................................... 44

Chimney Creek................................................. 45

Chicken Creek....................................................46

Yourname Creek..................................................... 47

Wales Creek.......................................................48 


\section{Table of Contents (cont.)}

PART III: Fish Population and Habitat Assessments for Restoration Streams.......50

Bear Creek...........................................................50

Blanchard Creek......................................................51

Chamberlain Creek..................................................... 52

Cottonwood Creek............................................................. 53

Elk Creek.........................................................5 54

Gold Creek........................................................56

Kleinschmidt Creek................................................57

McCabe Creek........................................................ 59

Monture Creek.........................................................59

Nevada Spring Creek...............................................6 60

Pearson Creek....................................................... 61

Rock Creek........................................................62

Spring Creek (trib. to the North For.................................... 62

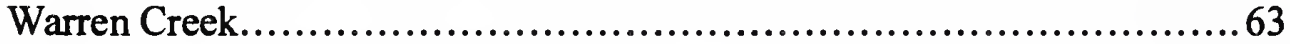

PART IV: Additional Aquatic Investigations

Tributary Temperature Summary...................................... 66

Blackfoot River Drought Management Strategies...........................67

Recreational Impacts to Blackfoot Fish Populations........................ 69

Species of Concern.............................................. 69

Angling Pressure Increases.................................... 70

Angler Inability to Identify Bull Trout and Other Salmonids.........71

Public Access Sites in Critical Native Fish Recovery Areas..........72

Illegal Introductions of Fish Species.............................. 73

Summary and Recommendations.............................. 74

Efficacy of Three Denil Fish Ladders for Low Flow Passage ................75

Evaluation of a Turbulent Fountain Fish Screen on McCabe Creek..........76

Habitat Evalulations in the Upper Blackfoot River and Landers Fork....... 78

North Fork Riparian Health Inventories............................... 83

CONCLUSIONS................................................................. 88

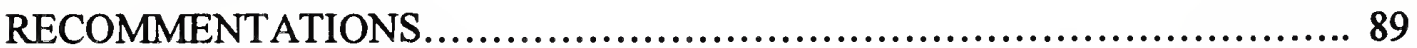

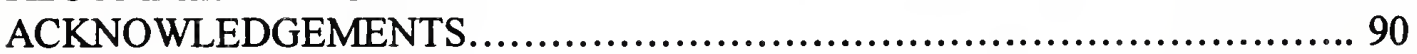

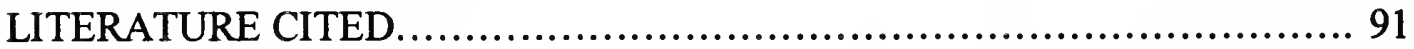

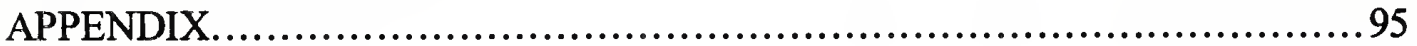




\section{Executive Summary}

The Blackfoot River watershed is the site of a comprehensive wild trout restoration initiative, with emphasis on native fish recovery. Through the 1990 s, priority for restoration has been directed to lower Blackfoot River tributaries from the North Fork downriver. Many of these tributaries are now approaching final restoration phases. As an initial effort to expand the restoration program, in 2000 we completed the second year of a Blackfoot River tributary assessment for streams outside of the current restoration focus area. Assessments began in 1999 with fish population inventories for 13 upper Blackfoot River tributaries upstream of Nevada Creek. In 2000, we completed fish population investigations in 22 Garnet Mountain tributaries located in the southern region of the Blackfoot Watershed. Investigations included fish population surveys, westslope cutthroat trout genetic samples, measurements of stream discharge and temperature, and problem identification such as riparian degradation. We found widespread problems affecting fish population on agricultural bottomlands and in the foothills of Garnet Mountain Range, and identified restoration opportunities on all 22 sampled tributaries. From this two-year inventory, we identified restoration potential on 34 of 35 inventoried streams. We aiso resurveyed fish populations on five restoration tributaries originating from the Garnet Mountains (Pearson, Chamberlain, Elk, Bear and Nevada Spring creeks).

We found westslope cutthroat trout (Onchorynchus clarki lewisi) distributed throughout upper tributary reaches of Garnet Mountains streams. However several streams supported low population densities, particularly in lower stream reaches. Of 20 sampled fish-bearing streams, 18 streams had westslope cutthroat trout, of which 16 showed declining densities in lower stream reaches.

Streams in the Garnet Mountains support very few bull trout (Salvelinus confluentus) with reproduction limited to two known streams (Poorman Creek and Upper Nevada Creek). In 2000, we captured only two individual bull trout in 22 streams (one in Chamberlain Creek and one in Bear Creek); both are past restoration project streams. We found brook trout (S. fontinalis) in six of 22 sampled streams. Brown trout (Salmo trutta) inhabit the lower reaches of several tributaries but were absent from all headwater areas. Likewise, rainbow trout $(O$. mykis) were also absent from all headwater samples, but present in a few lower river tributaries, except for two locations (Nevada Creek and Chicken Creek) below Nevada Reservoir where fish stocking contribute to rainbow trout presence.

In addition to tributary baseline inventories, in 2000 the Blackfoot River Restoration Initiative continued on several other fronts. We completed fish population restoration projects on 10 tributaries, and fish population monitoring on 16 project tributaries. Four streams (two spring creeks and two basin-fed) that received restoration prior to summer drought, recorded increased trout densities during the drought period. These increases demonstrate the importance of riparian health and habitat complexity in reducing drought impacts. In 2000 , we completed special studies on three Denil fish ladders and one experimental turbulent fountain fish screen. Study results show fish ladder and fish screens as capable of meeting fisheries objectives; however, maintenance of fish ladders and design/construction considerations on screens need to improve. A riparian inventory for the North Fork of the Blackfoot River ranked 70\% of surveyed reaches as healthy. 
In order to identify limiting factors to the upper Blackfoot River bull trout population, we surveyed habitats on the lower Landers Fork and upper Blackfoot River between Lincoln and the Landers Fork. These surveys identified habitat limitations in important bull trout rearing and wintering areas, and may help explain static population densities for the upper river bull trout. Habitat impacts partially relate to past government-sponsored channel "cleansing" (wood removal), riparian timber harvest, channel scouring during high flow events and the subsequent loss of instream wood.

We continued Blackfoot River fish population surveys at two long-term monitoring sections (Johnsrud and Scotty Brown Bridge) in May 2000. Fish densities increased for all trout species compared to 1998. Densities of westslope cutthroat trout, bull trout, and brown trout at both sections continued an upward trend that began in the early 1990s. Rainbow trout densities improved in 2000 compared to 1998.

During the summer of 2000, the Blackfoot River was subjected to drought conditions. By late July, record high temperatures prompted the Fish, Wildlife and Parks to call for voluntary angling restrictions for the Blackfoot River and bull trout "core" area tributaries. In early August, Governor Racicot closed all public lands and all recreational activity on public waters due to extreme fire danger. Dry summer conditions resulted not only in low flow conditions, but also the warmest river temperatures recorded since monitoring began in 1988. In anticipation of these drought conditions, a watershed-wide drought management plan under the guidance of the Blackfoot Challenge, was developed in spring and implemented by mid-summer. This plan, based on a concept of "shared sacrifice," included 1) the development of a "water bank", 2) called for voluntary reductions in irrigation and angling, and 3) developed a set of flow and temperature "triggers" for various phases of the drought plan. The drought plan helped maintain minimal flows and fish population in several critically dewatered tributaries as well as the Blackfoot River.

Recreational impact/native fish recovery conflict areas were identified in 2000. These delineations should assist in native species protection, restoration policies, and planning efforts to better manage recreation in critical bull trout recovery areas.

Whirling disease studies continued in several areas. Studies included two MS graduate student research projects and continued sentinel cage studies in the Blackfoot Watershed. Early results from a whirling disease sentinel cage study identified two more streams, Gold Creek and Rock Creek (tributary to the North Fork), as whirling disease positive in 2000. The restoration of Kleinschmidt and Warren Creeks will test if whirling disease can be reduced in degraded streams by improving stream health and reducing water temperatures.

\section{NATIVE FISH RESTORATION SUMMARY}

Four previous Blackfoot River reports detail bull trout and westslope cutthroat trout status, life history and restoration efforts on the Blackfoot Drainage (Peters 1990, Pierce et al. 1997, and Pierce and Schmetterling 1999, Pierce and Podner 2000). The following section summarizes past general findings, synthesizes new information and is presented to help guide future native fish recovery efforts. 


\section{Bull Trout Recovery}

Bull trout, "Threatened" under the Endangered Species Act (ESA), has been the focus of an extensive recovery program during the 1990s. The primary goals of Blackfoot bull trout recovery are to restore metapopulations, conserve genetic diversity, and restore and maintain connectivity within and between all restoration and seven conservation "core" areas (Montana Bull Trout Team 2000).

The Blackfoot River currently supports one of the better populations of riverdwelling (fluvial) bull trout within the range of the species. Still, fisheries investigations in the mid-to late 1980s found declining populations with local populations extirpated in several watersheds (Peters 1985, Peters 1990, Pierce et al. 1997).

Fluvial bull trout inhabit $100-110$ miles of the Blackfoot River mainstem, with densities very low in the upper Blackfoot River but increasing downstream of the North Fork at river mile 54. Outside of the Clearwater drainage, bull trout occupy $30 \%$ (22 of 74) of inventoried Blackfoot River tributaries $\sim 340$ miles of stream; eleven streams support extremely low population densities, two of which (Bear Creek and Dry Creek) were identified in 2000.

Beginning in 1994, bull trout radio-telemetry studies identified an upper and lower component to the Blackfoot River bull trout population. For lower river bull trout, Swanberg (1997) reported the mean upstream spawning migration of $\sim 39$ river miles for 30 bull trout captured in over-wintering areas in the lower Blackfoot River. This study confirmed a majority of Blackfoot fluvial bull trout reproduction and rearing occurs in Monture Creek and the North Fork Blackfoot River. Most of the spawning for a smaller upper Blackfoot River population occurs in Copper Creek; upper river bull trout appear to occupy a much smaller home range of $\sim 19$ stream miles (Swanberg and Burns 1997). Radio-telemetry also identified bull trout movement to specific areas of thermal refugia during periods of Blackfoot River warming (Swanberg, 1997). Fluvial bull trout from juvenile to adult life-stages exhibit migratory behavior and include movements young-ofthe-year (YOY) to small, cold, non-spawning streams.

Bull trout recovery began in 1990 with the adoption of catch-and-release fishing regulations. Since then, bull trout restoration projects were undertaken in five of seven "core" area (spawning and rearing areas) drainages, and several streams historically supporting bull trout (Pierce et al. 1997, Pierce and Schmetterling, 1999, Pierce and Podner 2000). Beginning in the early 1990s, we directed the majority of bull trout restoration to the Monture Creek and North Fork Blackfoot River watershed, which include eight headwater streams. Restoration included: 1) fish screening on nine irrigation ditches; 2) riparian livestock management

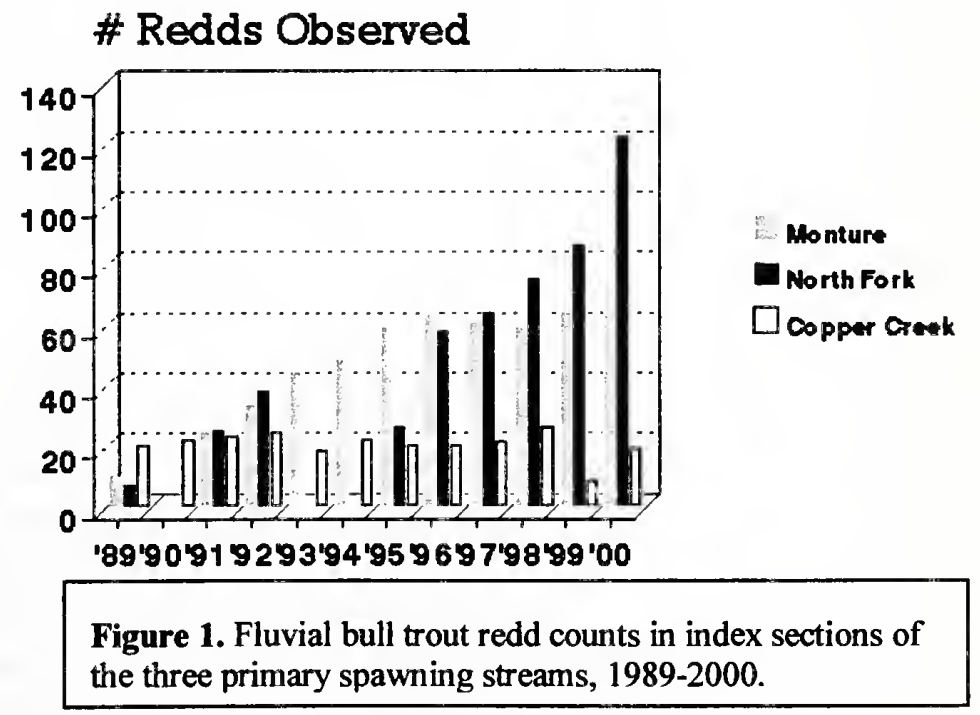


changes on 32 miles of riparian corridor; 3) removing seasonal migration barriers in three rearing tributaries; 4) instream habitat restoration and erosion control efforts on 15-miles of degraded stream; 5) increasing stream flows on five streams; 6) protection of spawning areas from livestock; and 7) enlisting landowners in perpetual conservation easements programs along 16-miles of riparian corridor. We completed similar but less extensive restoration directed to bull trout in three other core areas including the Gold, Belmont and Cottonwood Creek drainages. Many of these bull trout restoration projects are beginning to contribute to improved bull trout status in the lower Blackfoot River.

Bull trout densities at both lowerBlackfoot River sampling locations (Johnsrud and Scotty Brown Sections) are upward trending (Results Part I). Redd surveys in index reaches of both Monture Creek and the North Fork show increased bull trout reproduction (Figure 1). Likewise, densities of juvenile bull trout increased in both Monture Creek and the North Fork from 1990 to 1998 (Pierce and Schmetterling 1999). Between 1998 and 2000 juvenile densities remain static in Monture Creek, but declined in both Dunham Creek and North Fork-probably due to low flows and record warm temperatures. Juvenile bull trout appear to be incrementally expanding into several restored smaller "nonspawning" tributaries including Bear, Chamberlain, East Twin, Rock, Kleinschmidt and Spring Creeks (Pierce et al. 1997, Pierce and Schmetterling 1999).

Although densities and size of bull trout are now increasing in the lower river (Figure 2), fluvial bull trout status remains precarious in other areas including the upper Blackfoot River watershed. This area has received very limited restoration. Redd surveys for the upper river population, located in a long-term index reach of Copper Creek, show a static 10-year trend (Figure 1). Likewise, juvenile densities in Copper Creek show no signs of improvement (Pierce and Podner 2000). Bull

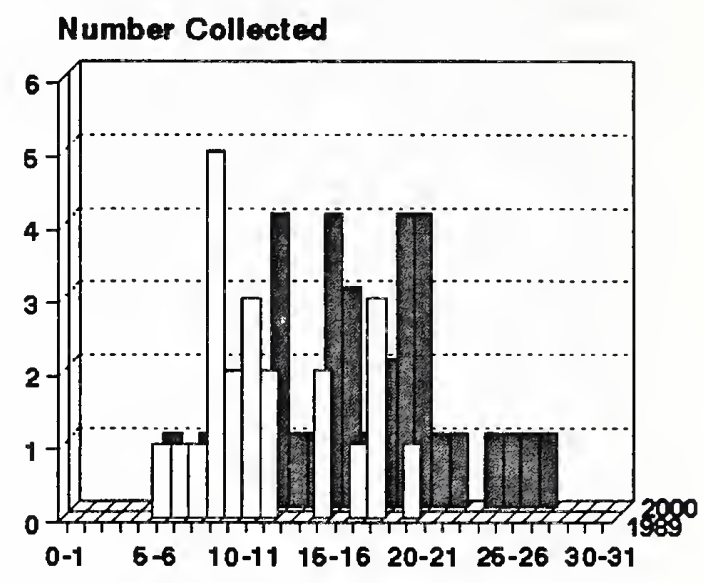

Number Collected

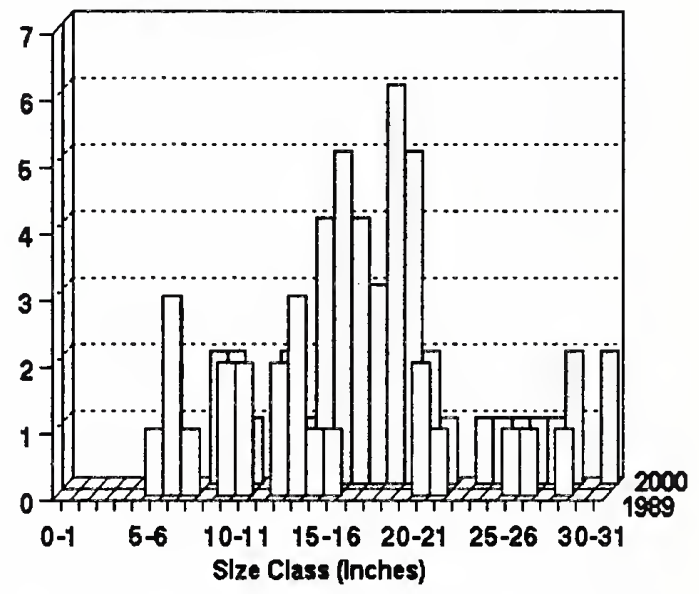

Figure 2. Length frequency histogram for bull trout sampled at the Johnsrud (upper) and Scotty Brown Bridge (lower) sections, 1989 and 2000. trout densities in the upper Blackfoot River remain very low (Pierce and Podner 2000).

Current densities (fish $>6.0^{\prime \prime}$ ) for the Blackfoot River range from 4.3 fish $/ 1000$ ' (2.5\% of the total trout population) in the lower river (Johnsrud Section) to $7.7 \mathrm{fish} / 1000$ ' ( $8 \%$ of the total trout population) in the middle Blackfoot River (Scotty Brown Bridge section). Bull trout densities in the upper Blackfoot River (upstream of Nevada Creek) are too low to estimate; however, 1999 catch statistics indicate densities (fish >6.0") range from one to two fish/1000'. We have not documented bull trout presence in the 
Blackfoot River between the North Fork and Nevada Creek. Poor water quality and elevated water temperatures are likely factors for bull trout absence in this 15 -mile river reach.

In order to help identify factors limiting bull trout in the upper Blackfoot River population, we conducted two habitat surveys upstream of Lincoln: 1) an evaluation of the Blackfoot River between Lincoln and the Landers Fork (6.3 miles); and 2) a second upstream survey extending from the mouth of the Landers Fork upstream 7.2 miles to Silver King Falls. These surveys found "simplified" habitat in channels used for migration corridors, rearing and over-wintering areas. Habitat simplification resulted partially from past riparian timber harvest, woody debris removal programs, channel scouring during major floods. These surveys identified two stream sections with restoration potential.

Since 1907, Milltown Dam, located at the mouth of the Blackfoot River, has blocked upstream bull trout migrations. A recent telemetry study recorded an $8 \%$ (3 of 37) direct loss of radioed Blackfoot River bull trout over Milltown Dam (Swanberg 1997). Milltown Reservoir also provides habitat for northern pike (Exos lucius); northern pike has shown a seasonal dietary preference for juvenile bull trout (Schmetterling 2001). In 2000 , six of seven adult bull trout, captured below Milltown dam, implanted with transmitters and released above the reservoir, migrated upstream an average of 53.7 river miles (range 49.6-79.0) to Blackfoot River tributaries (Schmetterling and Leirmann 2000). These studies clearly demonstrate the adverse impacts to bull trout from Milltown Dam, the large spatial extent of impacts to bull trout, and the need for fish passage at Milltown Dam

Additional concern for bull trout began to increase in the mid-1990s due to increases in angling pressure in important bull trout recovery areas. The middle Blackfoot River from Clearwater River to the junction of the North Fork provides critical life history requirements for the majority of the Blackfoot River bull trout population. In conjunction with spawning and rearing in Monture Creek and the North Fork Blackfoot River, fluvial bull trout use this river reach for rearing, migrations and over-wintering. This reach also supports seasonal concentrations of bull trout near the confluences of major tributaries during periods of river warming. From 1989 through 1999, total Blackfoot River angler pressure increased 186\%; resident angler use increased $144 \%$ compared to $408 \%$ for nonresident anglers. Meanwhile, total angler pressure in the middle reach of the Blackfoot River increased $540 \%$ with resident angler use up $406 \%$ compared to $1,135 \%$ for nonresident anglers (Statewide angler pressure estimates 1990, 2000). Unfortunately, these increases in the middle Blackfoot River are not evenly distributed, but rather concentrated from the North Fork to the Clearwater River, and overlap with a critical bull trout recovery area.

Recreational impacts to bull trout relate not only to upward trends in angling pressure in critical recovery areas, but also the inability of a large percentage of anglers, particularly non-resident anglers, to properly identify fish species. A survey conducted in 1995-1996 of anglers fishing the rivers and streams of western Montana found $43 \%$ of resident anglers correctly identified bull trout compared to only $22 \%$ of non-resident anglers (Schmetterling and Long 1999). The 1999 Blackfoot River creel survey found only $33 \%$ of surveyed anglers correctly answered bull trout identification questions, whereas $64 \%$ of surveyed anglers correctly answered the questions regarding bull trout 
fishing regulations (Schmetterling and Bohnemann 2000). The inability of anglers to identify bull trout and other species, combined with a general poor understanding of fishing regulations, result in non-compliance with angling regulations and the unintentional illegal harvest of bull trout. The Blackfoot River Management Plan combined with delineations of Native Species Management Areas and bull trout recovery/recreational conflicts areas should assist in developing policies to better manage river crowding and related resource conflicts in critical recovery areas.

\section{Westslope cutthroat trout Recovery}

Westslope cutthroat trout (WSCT hereafter) is classified a "species of special concern" in Montana by the American Fisheries Society and Montana Fish, Wildlife and Parks. Within the last 100 years, WSCT have declined throughout much of their historic range, particularly east of the Continental Divide. Liknes (1984) and Shepard et al. (1997) estimated that WSCT currently inhabit only about $20 \%$ of their former range in Montana, and genetically pure populations are found in less than $10 \%$ of their current range (Liknes and Graham 1988, Shepard et al. 1997). Reasons for the decline of WSCT include habitat loss and degradation, genetic introgression with introduced rainbow trout and Yellowstone cutthroat trout overharvest as well as competition with exotic species such as brook trout and brown trout (Liknes 1983, Allendorf and Leary 1988, Liknes and Graham 1988, McIntyre and Rieman 1995).

For the Blackfoot River watershed, WSCT are distributed basin-wide and is the most abundant fish species in the upper reaches of tributary streams. Ninety-two percent $(68$ of 74) of inventoried fish-bearing streams, outside of the Clearwater Drainage, contain WSCT. WSCT rely on high quality tributary habitats for spawning, rearing and overwintering. Access to the tributaries from the Blackfoot River is also necessary for the fluvial life-history form. Blackfoot River fluvial WSCT have shown complex and extensive spawning movements from the lower river system to headwater tributaries (Schmetterling 2000). Juvenile fluvial WSCT rear two to four years in small tributaries before migrating downstream to the Blackfoot River. Most of the known migration corridors occur on private lands in lower stream reaches. Spawning and rearing habitat is largely located on middle and upper stream reaches located on both private and public land. Although restoration has improved WSCT habitat on many streams, degradation on private land remains widespread. In 2000, 18 of 20 fish-bearing streams in the Garnet Mountains supported WSCT, and densities decreased in the downstream direction in 16 streams. Streams without WSCT were either degraded headwater streams or degraded spring creeks.

In conjunction with fluvial bull trout recovery efforts, the focus of fluvial WSCT restoration is reestablishing the fluvial life-history form by: 1) reducing or eliminating "controllable" sources of mortality; 2) maintaining or restoring existing spawning and rearing habitats; 3) restoring damaged habitats; and 4) reestablishing connectivity for the Blackfoot River to spawning areas. Restoration projects targeting these features were completed throughout the tributaries of lower Blackfoot River drainage during the decade of the 1990s. 
WSCT are now increasing in abundance in the lower elevations, including 108 miles of the mainstem Blackfoot River downstream of Poorman Creek. Like bull trout, the largest density increases for the Blackfoot River WSCT are occurring in the restoration focus area downstream of the North Fork Blackfoot River (Pierce and Podner 2000). Between 1989 and 2000, fluvial WSCT (fish $>6.0$ ") in the lower Blackfoot River increased $923 \%$ in the Johnsrud Section from 1.7 to 17.4 fish 1,000 ' and $758 \%$ in the Scotty Brown Bridge section from 2.9 to 24.9 fish $/ 1,000$, (Figure 3). WSCT densities increased in

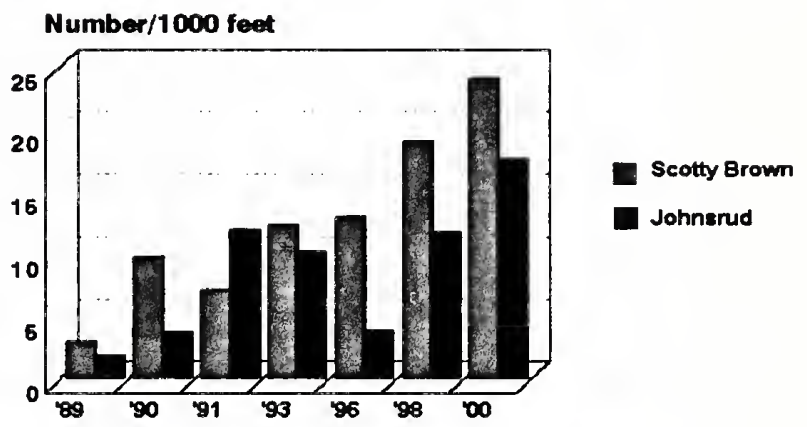
restored sections of the North Fork Blackfoot River, Monture, Chamberlain, McCabe, Pearson, Dunham, Spring, Warren and Cottonwood Creeks (Pierce and Schmetterling, 1999, Pierce and Podner, 2000). Radio-telemetry and related spawning surveys confirm several of these restored tributaries (Gold, Chamberlain, Pearson Dunham and Monture creeks) support populations of fluvial WSCT (Schmetterling 2000).

Milltown Dam exerts a negative influence on fluvial Blackfoot River WSCT. In 2000, eleven of 43 mature WSCT captured below Milltown Dam were implanted with radio transmitters and released upstream of the reservoir (Schmetterling and Leirmann 2000). Of these 11 WSCT, nine made spawning migrations, seven of which occurred in the Blackfoot Watershed. Upstream spawning migrations averaged 51.1 river miles (range 19.5-70.7). One radioed WSCT transported over Milltown Dam, swam up-river 54 miles before entering the North Fork; this fish then ascended Rock Creek and finally Dry Creek where it spawned following a 71-mile migration (Schmetterling, 2000). During the out-migration, this fish entered an irrigation ditch before its was recaptured and returned to Rock Creek to continued a downstream migration to the Blackfoot River. This long, complex and precarious migration demonstrates the spatial extent of Milltown Dam impacts to fluvial WSCT, the importance of an integrated basin-wide approach to restoration, which includes fish passage at Milltown Dam.

Catch-and-release regulations initiated in 1990 contribute to fluvial WSCT increases over the length of the Blackfoot River, including reaches upstream of the North Fork. These upper river reaches have received limited restoration activities. A 15 -mile section of the middle Blackfoot River between the North Fork and Nevada Creek support particularly low WSCT densities (Pierce and Podner, 2000).

Habitat degradation and low fish densities in this middle reach were initially identified in 1988 (Peters and Spoon 1989). Since then, low fish densities were traced to water quality problems, reduced riparian health and the lack of functional tributaries entering this reach (Ingman et al. 1990, Pierce et al. 1997, Marler 1998). In 1999, we found comparable low densities to 1988, continued weak recruitment, and the among the lowest WSCT densities found in the Blackfoot River below Poorman Creek (Peters and Spoon 1989, Pierce and Podner 2000).

The 2000 Garnet Mountain fish population inventories confirmed low trout densities, and degraded and dewatered tributaries entering this river reach. Several Garnet 
Mountain streams, of which Nevada Creek is the largest, enter this reach; all support much higher westslope WSCT densities in headwaters areas than in downstream reaches. Low densities relate to chronic dewatering, degraded riparian areas, non-point water quality problems and fish losses to irrigation ditches (Results Part II). If fish densities in the middle reach of the Blackfoot River are to improve, Nevada Creek and the lower reaches of adjacent Garnet Mountain tributaries will require expanded commitment to riparian land management changes, including irrigation upgrades, water conservation and other restoration methods similar to those undertaken in the downstream restoration focus area. 


\section{Introduction}

Fish population studies in the late 1980s and early 1990s identified that 1) mining impacts in the headwaters, 2) over-exploitation of the fishery, and 3) extensive degradation of tributary habitats contributed to declining Blackfoot River fish populations. Beginning in the mid-1990s, additional fisheries concern emerged with the introduction of several exotic organisms, as well as uncontrolled recreational increases in critical native species recovery areas.

Early studies documented low densities of native westslope cutthroat trout (Onchorynchus clarki lewisi) at the mid- to low elevations of the Blackfoot Watershed (Peters and Spoon 1989, Peters 1990). Bull trout (Salvelinus confluentus) densities were low basin-wide, with local populations extirpated in several streams. Fish population investigations found that early life-stages of salmonids in the lower Blackfoot River rely on tributaries. Tributary assessments reported extensive problems, spanning multiple land ownerships that resulted in fish population declines at a watershed scale (Peters and Spoon 1989, Peters 1990, Pierce et al. 1997, Pierce and Schmetterling 1999, Pierce and Podner 2000).

Low numbers of adult rainbow (O. mykis) and brown trout (Salmo trutta) at the low to mid elevations of the watershed, combined with high winter mortality of youngof-the-year (YOY) trout and poor tributary habitats resulted in weak recruitment to river populations for these species (Peters and Spoon 1989, Peters 1990, Pierce et al. 1997). Reliance of native fish on upper tributary reaches at early life stages indicates adaptation to the severe environment of the Blackfoot River. However, due to 1) poor tributary conditions, 2) long migrations, 3) high fidelity to natal streams, 4) barriers to movement, and 5) more extensive use of the tributaries at early life stages, fluvial native fish are also more subject to human impacts in the tributary system than introduced fish species. By contrast non-native rainbow and brown trout spawn in lower stream reaches or the upper mainstem Blackfoot River, migrate shorter distances, have less fidelity to their natal streams and use lower tributary environments.

Throughout the 1990s, the Blackfoot River watershed was the site of cooperative private and public lands fisheries restoration initiative. During this effort, 37 tributaries to the Blackfoot River received special riparian and upland restoration activities that provide for riparian-dependant species including a diversity of self-sustaining wild trout populations. We prioritized restoration to streams supporting populations of WSCT and bull trout, especially tributaries of the lower to middle Blackfoot River (Figure 4). Restoration tools include reconstructing stream channels and restoring habitat features to damaged streams, developing low impact grazing systems and removing streamside feedlots, planting native riparian vegetation, improving stream flows, restoring fish migration corridors and enrolling landowners in perpetual conservation easement programs. Cooperators included private landowners, private companies, non-profit groups, and state and federal agencies.

Restoration has contributed to improved native fish populations at the low to mid elevations of the watershed. WSCT densities have increased $750-920 \%$ in the lower to middle reaches of the Blackfoot River downstream of the North Fork confluence. Several tributaries support increased WSCT densities. Bull trout densities are increasing in the lower river system including both Monture Creek and the North Fork Blackfoot 
River, but remain static upstream of Nevada Creek.

Although fish populations are improving in the lower watershed, correcting major habitat problems (timber, mining and agricultural impacts) is far from complete. Most of the Blackfoot Watershed (upper Blackfoot River drainage upstream of Nevada Creek, Nevada Creek drainage, Clearwater River drainage and Garnet Mountains) has received limited restoration. In addition, several issues beyond the original scope of identified problems have emerged in the last several years. These additional challenges to the conservation of wild trout include: 1) the recent introduction of four exotic fishes including northern pike (Exos lucius) to the Blackfoot River drainage; 2) the remediation of Milltown Dam impacts; 3) the introduction of Myxobolus cerebralis and expansion of whirling disease; and 4) upward trends in recreational river use in critical bull trout recovery areas, combined with the inability of a growing number of anglers to identify bull trout (Schmetterling and Long 1999, Bohnemann and Schmetterling 2000). The long-term conservation of native fishes requires expanded effort to address these emerging issues, some of which present formidable challenges.

In 2000, we continued to correct habitat problems in the lower watershed. We also completed a two-year investigation of fish populations outside of the current restoration focus area. The 2000 effort included baseline fish population and riparian assessments for 22 Garnet Mountain streams, bringing the total number of inventoried tributaries during this two-year period to 35 . We also completed several other fisheries-related investigations in 2000 , including restoration project monitoring, fish screen and fish ladder evaluations, riparian health inventories on the North Fork, stream habitat assessments in the upper Blackfoot River, whirling disease studies, drought planning triggers and delineation of recreational impact/native fish recovery conflict
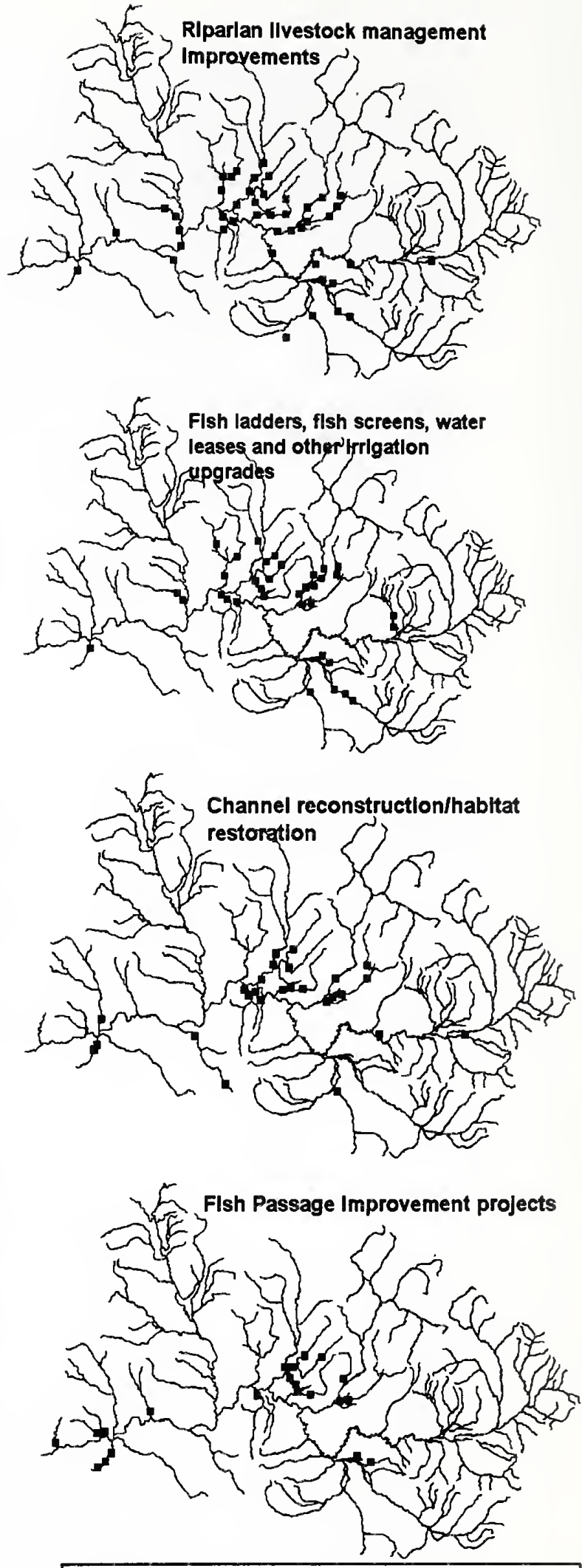

Figure 4. Location map of principal restoration activities 
areas.

Primary objectives of the report are to: 1) document fish population changes in the lower Blackfoot River; 2) report fish population inventory results for the Garnet Mountains and identify restoration potential; 3) report changes in the species composition and densities of fish and changes in their habitats resulting from restoration efforts; 4) present results of other aquatic studies which relate to the health and recovery of Blackfoot River fish populations; and 5) help guide future restoration activities.

\section{Study Area}

The Blackfoot River, located in west-central Montana, begins at junction of Beartrap and Anaconda Creeks, and flows west 132 miles from its headwaters near the Continental Divide to its confluence with the Clark Fork River at Bonner, Montana (Figure 5). Mean annual discharge is 1,597 cubic-feet-per-second (cfs).

This river system drains a 2,320 square mile watershed through a 3,700-mile stream network of which 1,900 miles are perennial streams capable of supporting fishes. The physical geography of the watershed ranges from high elevation glaciated alpine meadows to prairie pothole topography on the valley floor. Glacial landforms, moraine and outwash, glacial lake sediments and erratic boulders cover the floor of the entire Blackfoot River valley and exert a controlling influence on the habitat features of the Blackfoot River and the lower reaches of most tributaries. The Blackfoot River is a free flowing river to its confluence with the Clark Fork River where Milltown dam, a run-ofthe-river hydroelectric facility, has blocked upstream fish passage since 1907.

Land ownership in the Blackfoot watershed is $44 \%$ National Forest, $5 \%$ Bureau of Land Management, 7\% State of Montana, 20\% Plum Creek Timber Company and 24\% other private ownership. In general, public lands and large tracts of Plum Creek Timber Company properties comprise the forested mountainous areas while private lands occupy the foothills and lower valley areas (Figure 5). Traditional land-use in the basin includes mining, timber harvest, agriculture and recreation activities, all of which have contributed to habitat degradation or fish population declines. Of 77 inventoried streams, 73 have been altered, degrade or otherwise identified as fisheries-impaired since the inventory efforts began in 1989. The majority of habitat degradation occurs on valley floor and foothills of the Blackfoot watershed and largely on private agricultural ranchlands. However, problems also extend to timbered areas and mining districts located on state and federal public lands.

The Blackfoot River is one of twelve renowned "blue-ribbon" rivers in Montana with an appropriated "Murphy" in-stream flow water right. The Montana Fish, Wildlife and Parks manages the Blackfoot River and tributaries for a diversity of self-sustaining "wild trout" populations. Distribution patterns of most salmonids generally conform to the physical geography of the landscape, with species richness increasing longitudinally in the downstream direction (Figure 6). Species assemblages and densities of fish can also vary greatly at the lower elevations of the watershed.

Most salmonids (WSCT, bull trout, rainbow trout and brown trout) in the river system exhibit migratory life-history characteristics. WSCT has a basin-wide distribution and is the most abundant species in the upper reaches of the tributary system. Bull trout distribution extends from the mainstem Blackfoot River to headwaters of larger 
tributaries north of the Blackfoot River; however, juvenile bull trout will rear in smaller "non-spawning" tributaries, some of which are located in the Garnet Mountains. Rainbow trout distribution is limited to the Blackfoot River below Nevada Creek and lower reaches of the lower river tributaries; this species occupies approximately $8-10 \%$ of the perennial streams in the Blackfoot Watershed and reproduces primarily in the lower portions of larger south flowing tributaries. Brown trout inhabit about $15 \%$ of the perennial stream system with a distribution that extends from the Landers Fork down the length of the Blackfoot River and into the lower foothills of the tributary system. Brook trout are widely distributed in tributaries but rare in the mainstem Blackfoot River below the Landers Fork.
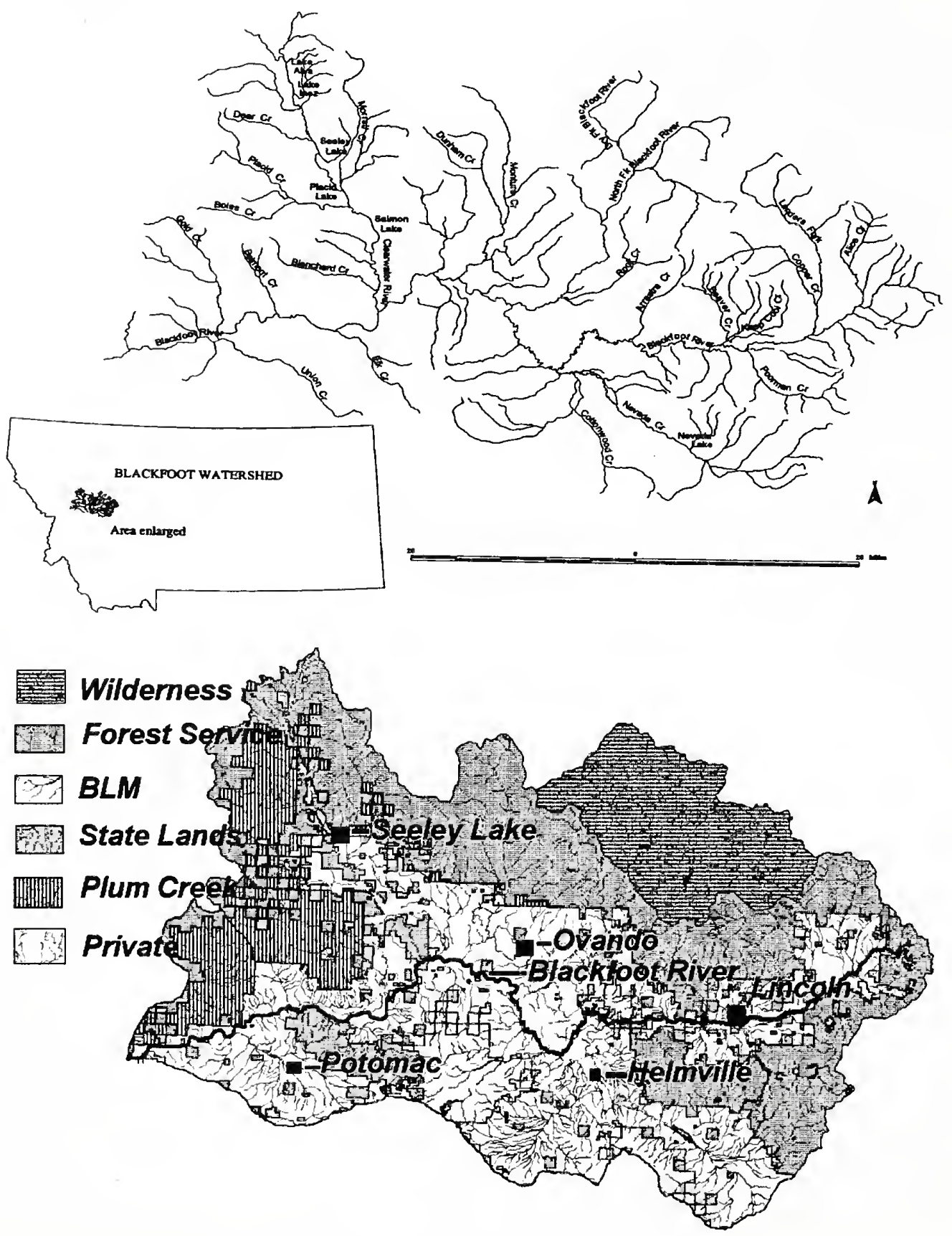

Figure 5. Study area: The Blackfoot River watershed with generalized landownership. 
Figure 6. Trout distribution for the Blackfoot River watershed.
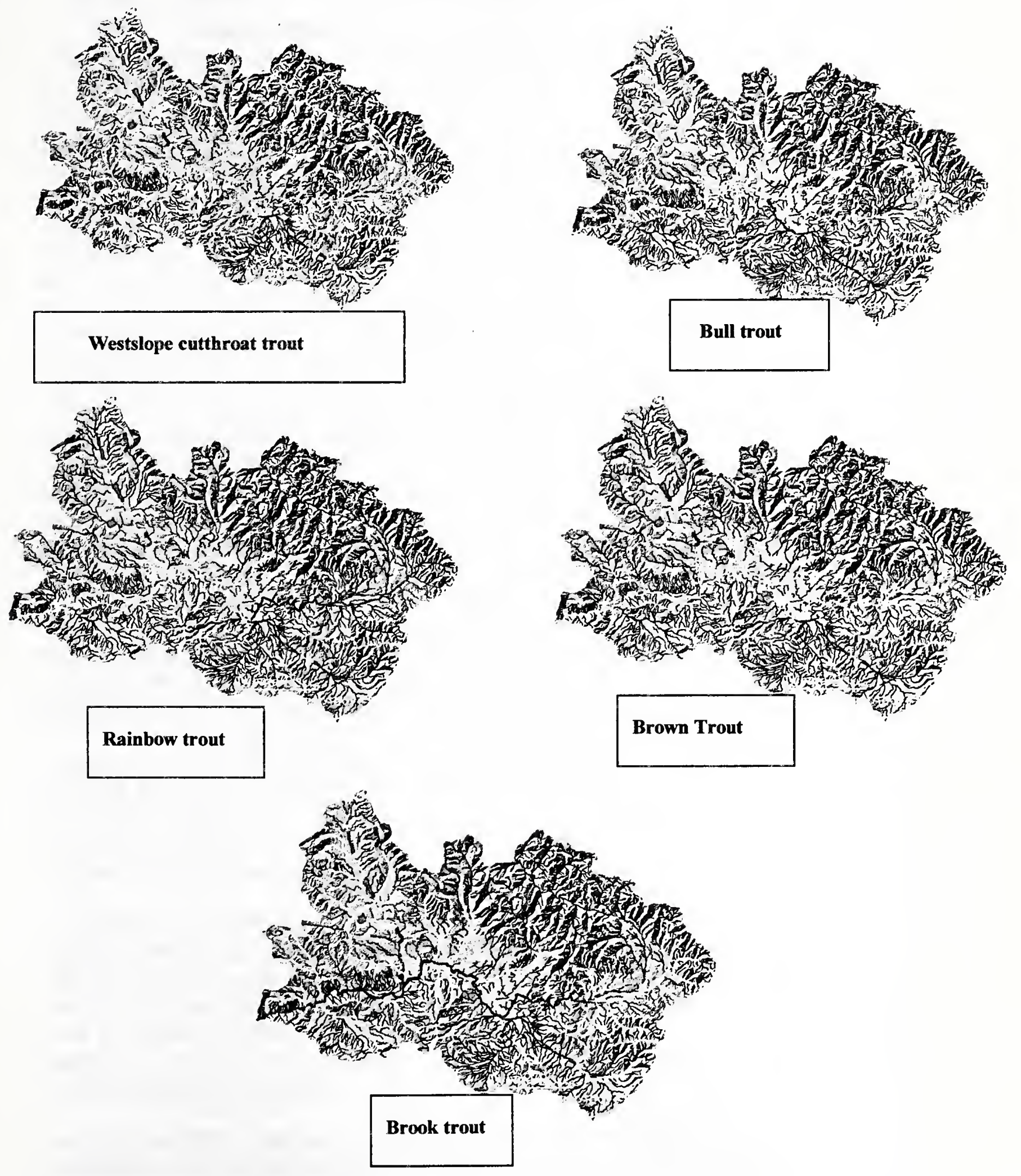


\section{Procedures}

\section{Working with Private Landowners: the Key to Successful Restoration}

The focus of the Blackfoot River restoration initiative is to restore degraded tributaries by improving riparian health and fish habitat. Typically, each tributary project involves multiple landowners, multiple professional disciplines, more than one funding source and the involvement of a watershed group. Restoration has focused on addressing obvious impacts to fish populations such as migration barriers, stream de-watering, fish losses to irrigation canals and degraded riparian areas. All projects are cooperative efforts between private landowners and the restoration team, and occur throughout the drainage with emphasis on tributaries from the North Fork down river. All projects are voluntary, incorporate landowner needs (such as irrigation and grazing objectives), and are administered at the local level by a core group of agency resource specialists in cooperation with local watershed groups, including both the Big Blackfoot Chapter of Trout Unlimited and the Blackfoot Challenge, or local government groups such as the North Powell Conservation District. Tax incentives of the watershed groups with nonprofit 501(c)(3) status is key to generating private dollars for restoration.

Two full-time restoration biologists help coordinate restoration efforts (wildlife biologist from the U. S. Fish and Wildlife Service-Partners for Fish and Wildlife Program, and a fisheries biologist from the Montana Fish, Wildlife and Parks). A lead biologist generally enlists help from interagency personnel including range conservationists, hydrologists, engineers and water rights specialists as necessary. In turn, the watershed groups help prioritize projects, administer budgets, solicit bids and assist with landowner contacts, resolve conflicts and help address other social issues.

Cost-sharing of projects is arranged by project personnel and comes from many sources including landowner contributions, private donations, foundation grants, and state and federal agency programs. Project biologists and/or the watershed group undertakes grant writing and fund-raising. The lead biologist usually writes environmental assessments and obtains project permits on behalf of the cooperating landowner.

Project bids (consulting and construction) conform to State and Federal procurement policies. These policies included the development of Blackfoot Watershed qualified vendors lists $(\mathrm{QVL})$ derived through a competitive process. A minimal project cost triggers use of the QVL. The watershed groups solicit bids from the QVL for both consulting and contractor services. Bid-contracts are signed between the watershed group and the selected vendor upon bid acceptance.

Depending on the specific project, landowners are responsible for much of the cost, construction and maintenance of projects. Addressing the source of stream degradation usually requires developing riparian/upland management options sensitive to the requirements of fish and other riparian-dependent species. Written agreements (15-30 year period) with landowners to maintain projects are arranged with cooperators on each project. These agreements vary by funding source and may include agencies, the North Powell Conservation District and/or the Fish and Habitat Committee of the Big Blackfoot Chapter of Trout Unlimited.

Landowner awareness of the habitat requirements of fish and wildlife and their full participation in projects are considered crucial to the long-term success of the restoration initiative. Landowners are encouraged to participate in all project phases from fish 
population data collection, to problem identification, restoration and monitoring of completed projects. Although many restoration projects have been completed in the Blackfoot River watershed, this effort is considered educational at a broad level and is far from complete. Five major steps to our restoration process are further described in Appendix E.

\section{Fish Population Investigations}

Fish population densities were calculated using single-pass, mark-recapture, or multiple pass-depletion methods. We used mark-recapture in the Blackfoot River and depletion estimates in small streams. Population densities using the mark-recapture method were estimated using Chapman's modification of the Petersen formula (Ricker 1975); confidence intervals were calculated using the Seber Formula.

For small streams, fish population surveys rely on two general methods. The first is a single pass catch-per-unit effort (CPUE); this provides an index of relative abundance. The second is a population density estimate generated from a two-pass depletion survey. We used simple linear regression to analyze the degree of association between the two methods. The result indicated a close relationship between the two methods, Rsquare $=0.902, \mathrm{P}<0.0001$ (Pierce et al. 1997). Small stream size and highly efficient electrofishing conditions in our study streams contributed to this outcome. Although the model demonstrates CPUE to be an index to population density, CPUE does not include a confidence interval like the actual population density estimate. For this report, CPUE refers to the number of fish collected in a single electrofishing pass and is adjusted per 100 feet of stream (I.e. CPUE of 8 means 8 fish captured per 100' of sampled stream). Actual population estimates are referred to as density $/ 100$ '. The $95 \%$ confidence intervals for these estimates are found in Appendix B.

Fish were captured using a boat or backpack mounted electrofishing unit. In small streams, we used either a gas-powered (Coffelt Mark 10) or battery powered (Smith/Root) backpack mounted DC electrofishing unit. The anode (positive electrode) was a hand-held wand equipped with a 1-foot-diameter hoop; the cathode (negative electrode), a braided steel wire. On the Blackfoot River (Johnsrud and Scotty Brown Bridge sections), we used an aluminum drift boat mounted with a Coffelt Model VVP-15 rectifier and 5,000 watt generator. The hull of the boat was used as a cathode and two fiberglass booms, each with four steel cable droppers, served as anodes. We used direct DC current forms with output less than 1000 watts, which is an established method to significantly reduce spinal injuries in fish associated with electrofishing. Juvenile trout were sampled in the tributaries from August to November. Extra effort was used to sample stream edges and around cover to enable comparisons of densities between sampling sections. Captured fish were anesthetized with either methansulfonate (MS222 ) or clove oil, weighed $(\mathrm{g})$ and measured $(\mathrm{mm})$ for total length (TL). For this report, we converted all weights and lengths to standard units.

\section{Bull Trout Redd Surveys}

Bull Trout redds were surveyed in Copper Creek, Monture Creek and North Fork Blackfoot River. Redd counts were not complete counts and serve as an index of spawning adult abundance in selected reaches. Counts were made by walking the spawning areas in late September. Redd areas were identified by a cleaned, oval shape 
(pit), and a mound of unconsolidated gravel (tailspill) left by the females digging activities. Only redds where a definite pit and tailspill were discernable were counted.

\section{Whirling Disease Sentinel Cage Studies}

Whirling disease surveys including live fish cage studies were undertaken in the Blackfoot Watershed in 2000. The live cage study is a controlled experiment used to detect levels of whirling disease. Detection of whirling disease relied on histological examination of hatchery rainbow trout placed in sentinel cages. The live cages used consisted of an $18 \times 24$ " cylindrical screened container placed into a stream site allowing stream water to flow through the cage. Each cage contained 50 uninfected 35-60 mm rainbow trout or WSCT supplied by a state fish hatchery. Timing of field exposure was based on anticipated mean daily temperatures in the 50 's $(\mathrm{F})$, which correlates with peak triactinomyxon (TAM) production, and correspond to peak infection rates in fish. The exposure period for each live cage was standardized at 10 days. At the end of the 10-day exposure period, the trout were removed and taken to Pony, MT, where they were held for an additional 80 days at a constant $50^{\circ} \mathrm{F}$ temperature to insure the WD infection would reach its maximum intensity. At the end of the 90 day period all the surviving fish were sacrificed and sent to the Washing State University Animal Disease Diagnostic Laboratory at Pullman, WA. At the lab, the heads were histologically examined and infection intensity 0 (absent) to 5 (severe) was assigned each fish. The results of this histological rating were presented as percent of fish infection intensity. Every live cage site also had an accompanying thermograph to establish mean daily water temperatures during this exposure period.

\section{WSCT Genetic Investigations}

In 2000, WSCT genetic samples were taken from 19 Garnet Mountain tributaries. Samples consisted of non-lethal tissue samples (fin-clip) taken from 25 individual fish when possible. Samples collected were immediately preserved in $95 \%$ ethyl alcohol and taken to the University of Montana, Salmon and Wild Trout Genetics Lab for electrophoretic analysis.

The Paired Interspersed Nuclear DNA Element-PCR (PINE-PCR) method was used to determine each fish's genetic characteristics at 21 regions of nuclear DNA. This method produces DNA fragments (PINE markers hereafter) that distinguish WSCT, from rainbow trout and Yellowstone cutthroat trout $(O$. clarki. bouveri). These species, specific PINE markers, therefore, can be used to determine whether a sample came from a genetically pure population of one of these fishes or one in which hybridization between two or all three of them has occurred. With a sample size of 25 fish, this testing method has a $95 \%$ chance of identifying as little as $1 \%$ introgression ( $R$. Leary, personal communication).

\section{Stream Temperature}

Warming during summer period, in the mid-to-lower reaches of the Blackfoot River, periodically increases to levels considered stressful for salmonids ( $>70$ degrees $F$ ). During the summer of 2000 , we completed a stream temperature study directed primarily to lower reaches of Garnet Mountain tributaries. The study included seven Blackfoot River sampling locations, including four long-term sampling locations, plus 25 sampling 
sites on 17 tributaries. Of these 17 tributaries, 8 are direct tributaries to the Blackfoot River originating in the Garnet Mountains. For these 8 tributaries, temperature sensors were placed near their confluences with the Blackfoot River.

Objectives of the temperature study were to: 1) profile temperatures over the length of the river; 2) identify thermal properties of Garnet Mountain tributaries which enter the river; 3 ) identify thermal regimes favorable and unfavorable for trout throughout the system; 4) develop temperature stress triggers for the drought management plan; 5) monitor stream restoration projects; and 5) establish additional baseline for future study and support current graduate student whirling disease studies.

In 2000 , water temperatures $\left({ }^{\circ} \mathrm{F}\right)$ were recorded at 48 to 72 minute intervals using Hobo temperature data loggers. Data for each station is summarized with monthly mean, maximum, minimum and standard deviation in Appendix I.

\section{North Fork Blackfoot River Riparian Health Inventories}

In 2000, a riparian health inventory was completed on 9.6 miles of the North Fork Blackfoot River (Marler 2001). The inventory relied on high-resolution aerial (ADAR) imagery as a base layer in Arc View and as field maps. The aerial imagery was collected by Positive Systems, Inc. of Whitefish, Montana, and was georectified by Geodata of Missoula, Montana. The study section was accessed by a raft in July 1998. The results were computer mapped and summarized in winter 2000-01 after the aerial images were georectified. Features mapped include noxious weeds, eroded banks, and riparian health. Noxious weeds were mapped according to the Montana State weed mapping guidelines (Cooksey and Sheley 1998). Health ratings are based on the University of Montana Riparian and Wetland Research Program system previously used for Blackfoot River inventories (Marler 1998, 1999). The system assigns a health category of either healthy, at risk, unhealthy based on amount of erosion and channel incisement, as well as the condition of riparian vegetation, including presence of noxious weeds. Dominant plant communities along the study area were noted but not mapped. Plant communities are described according to Hansen et al. (1995).

\section{Habitat Surveys in the Upper Blackfoot River and Landers Fork}

In October 2000, we conducted two habitat surveys: one on the upper Blackfoot River between Stemple Pass Road; and a second survey from the mouth of the Landers Fork 7.2 mile upstream to Silver King Falls. Because of the their importance of providing bull trout habitat, the primary objective was to determine the frequency and size of pools along with the amount, size, and function of the large woody debris associated with the pools. We also collected geomorphic information including bankfull measurements and Wohlman pebble counts (Rosgen 1996).

Our methods for both surveys included measuring the distance and location of pools using a global positioning satellite receiver (GPS). We measured total pool length, bankfull width and depth of pools, wetted-width and wetted-depth of pools, width of the flood prone area and channel slope. We also recorded the substrate and channel type (Rosgen 1996). Methods for measuring the woody debris associated with each pool included, counting the number of pieces $\left(\geq 4^{\prime \prime} \times 6^{\prime}\right)$, and measuring the length and diameter of randomly-selected woody stems pieces to estimate a range and average size in channel wood. We also recorded the function of the wood (e.g. vertical scour). 
For the Blackfoot River, we counted and measured all the wood within bankfull width for the entire 6.3-mile survey section. For the upper 2.4 miles of perennial stream, we counted all pools and measured parameters of every fourth pool. We also counted all functional instream wood, as well as wood within bankfull width. We surveyed habitat for a section for a 7.25-mile stream reach extending from Silver King Falls downstream to the mouth (mile 116.1). We counted 37 pools in the survey section and measured 16 intensively. 


\section{RESULTS IDISCUSSION}

PART I: BLACKFOOT RIVER ENVIRONMENT

\section{Blackfoot River Discharge}

With the onset of the summer drought season, the Blackfoot River ended five years of favorable summer base-flow conditions. In August 2000, summer flow fell to a low of $466 \mathrm{cfs}$ or $56 \%$ of mean August flow of $851 \mathrm{cfs}$. This low flow was $18 \mathrm{cfs}$ below the one-in-ten year low-flow event of 484 cfs (USGS 2000). The relative drought index for the calendar year 2000 show daily river discharge at $<75 \%$ of mean monthly flows on 144 days and 25 days for flows at $<50 \%$ (Figure 7). These flow declines occurred primarily from June through September; winter base flows approached normal. For 2000, mean flow was $1,222 \mathrm{cfs}$, or $76 \%$ of mean annual discharge $(1,597 \mathrm{cfs})$ for the period of record between 1940 and 2000 (Figure 8). These values show the year 2000 was the $3^{\text {rd }}$ lowest lowflow year since 1989. Both 1992 and 1994 produced less total annual flow than 2000.

\section{Blackfoot River Temperatures}

We collected summer water temperatures at seven Blackfoot River monitoring sites, including three longterm monitoring locations (Scotty Brown Bridge, Raymond Bridge, and Cutoff Bridge).

In 2000, Blackfoot River summer temperatures were the highest recorded since monitoring began in the drought year of 1988, with six of seven Blackfoot River monitoring stations $>70^{\circ} \mathrm{F}$. Only the Blackfoot River station near Lincoln did not exceed $70^{\circ} \mathrm{F}$ due to large inflows of groundwater.

From Lincoln down stream to Bonner, mean August temperatures for the Blackfoot River increased $\sim 8^{\circ} \mathrm{F}$. Mean August temperature in a 38-mile section of the Blackfoot River from Lincoln (mile 107) to the Cutoff Bridge (mile 69) increased $5.4^{\circ} \mathrm{F}$ $\left(53.9-59.3^{\circ} \mathrm{F}\right.$ ). Mean temperatures then increased an additional 5.1 degrees in a 9-mile river section between the Cutoff Bridge and Raymond Bridge at river mile 60 (Figure 9). 
From Raymond bridge 15-miles down river to Scotty Brown Bridge (mile 45), mean temperatures decreased $4.0^{\circ} \mathrm{F}$ from 63.4 to $59.6^{\circ} \mathrm{F}$ due to the cooling influence of the North Fork Blackfoot River. From Scotty Brown Bridge down stream to the weigh station near Bonner (mile 1.0) mean ambient river temperature gradually increased $3.4^{\circ} \mathrm{F}$ over a distance of 44 river miles.

$$
\text { Maximum }
$$

river temperatures for August ranged from a low of $65.0^{\circ} \mathrm{F}$ near

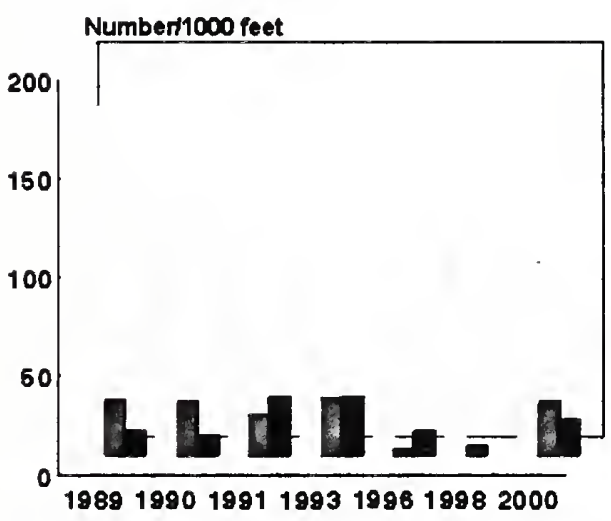

Figure 10. Estimated rainbow trout densities in the Johnsrud Section, 1989-2000.

\section{Blackfoot River Trout Populations}

\section{Johnsrud Section}

In May 2000, trout species composition ( $\%$ of total catch) in the Johnsrud section was $73.7 \%$ rainbow trout $(\mathrm{n}=937), \quad 12.5 \%$ brown trout $(\mathrm{n}=159), 11.6 \%$ WSCT $(\mathrm{n}=148)$ and 2.2 $\%$ bull trout $(\mathrm{n}=28)$. This represents almost no change in the species composition compared to 1998 . Densities however increased for all trout species. Density increases began in 1996

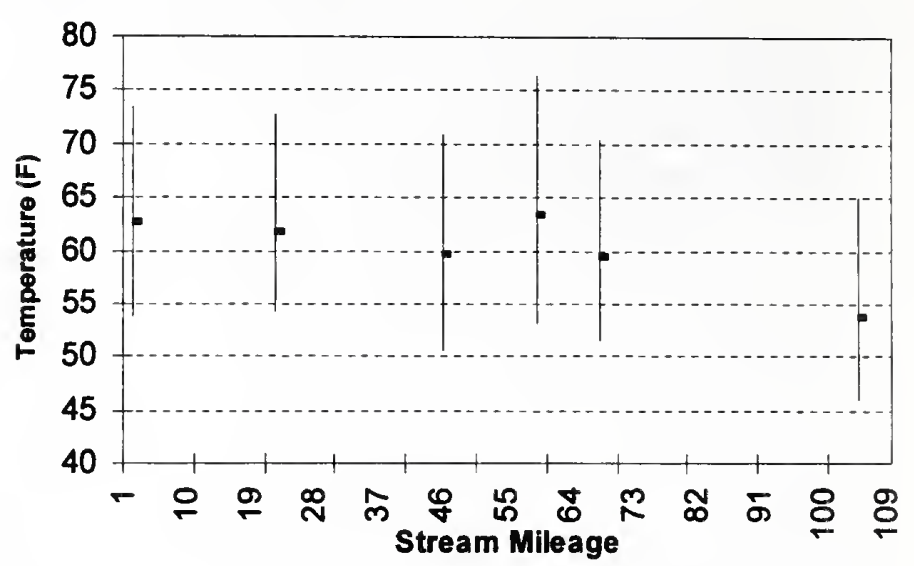

Figure 9. Maximum, minimum and mean Blackfoot River temperatures at six locations for summer 2000.

Lincoln to a high of $76.6^{\circ} \mathrm{F}$ at Raymond Bridge. As in past years, summer water temperatures at Raymond Bridge were consistently higher than all other Blackfoot River monitoring stations. Nevada Creek with water temperatures in high 70 s contribute to warming trends. All five additional Blackfoot River stations recorded maximum August temperatures in the low 70s (range 70.3$73.5^{\circ} \mathrm{F}$ ) (Figure 9). Maximum river temperatures in 2000 were $3-6^{\circ} \mathrm{F}$ warmer than 1999 river temperatures.

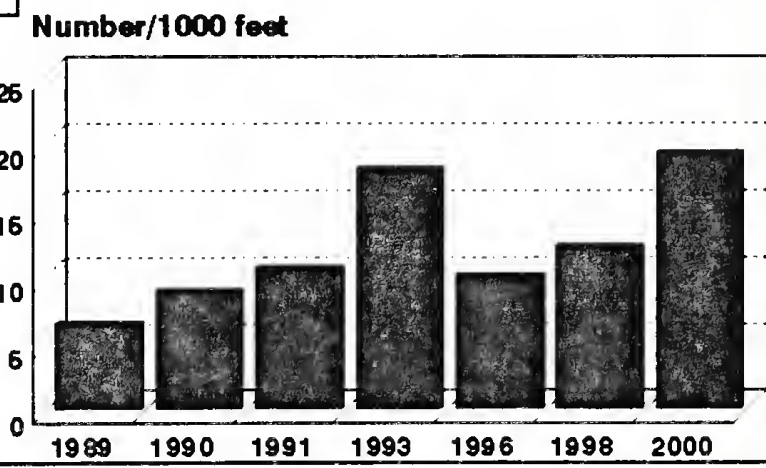

Figure 11. Estimate brown trout densities (fish $>6.0$ ") for the Johnsrud section 1989-2000. 
following large population declines-the result of a very large ice-flow in February 1996 (Pierce et al. 1997). In 2000, total trout (fish $>5.0$ ") densities increased $38 \%$ from 137 fish/1000' in 1998 to 189 fish/1000' in 2000 .

In 2000, rainbow trout (including rainbow $x$ cutthroat hybrids) increased in the intermediate (10.0-11.9") and larger (>12.0") size classes and returned to more stable densities (Figure 10). However, the point estimate for smaller rainbow trout class (5.09.9") decreased slightly from 104 to 99 fish/1000' compared to 1998 . Rainbow trout in the intermediate class (10.0-11.9") recorded a significant increase from an estimated 4.6 fish $/ 1000^{\prime}$ in 1998 to $27 \mathrm{fish} / 1000^{\prime}$ in 2000 . We estimated densities of larger rainbow trout (fish $>12.0$ ") at 17.9 fish $/ 1000$ ' in 2000. We did not attain an estimate of rainbow trout (fish >12.0") in 1998 due to low population densities and/or low-sampling efficiencies.

From 1998 to 2000, combined densities of WSCT, bull trout and brown trout (fish $>6.0$ ") increased $53 \%$ from 26.7 to 40.8 fish/1000'. These three species continued an upward trend that began in the early 1990s. Densities of WSCT and bull trout (fish $>6.0$ ") increased from 12.2 to 17.4 for WSCT, and 2.4 to 4.3 fish $/ 1000$ ' for bull trout between 1998 and 2000. The point estimate for brown trout (fish $>6.0$ ") increased from 12.1 to 19.1 fish/1000' between 1998 and 2000 (Figure 11).

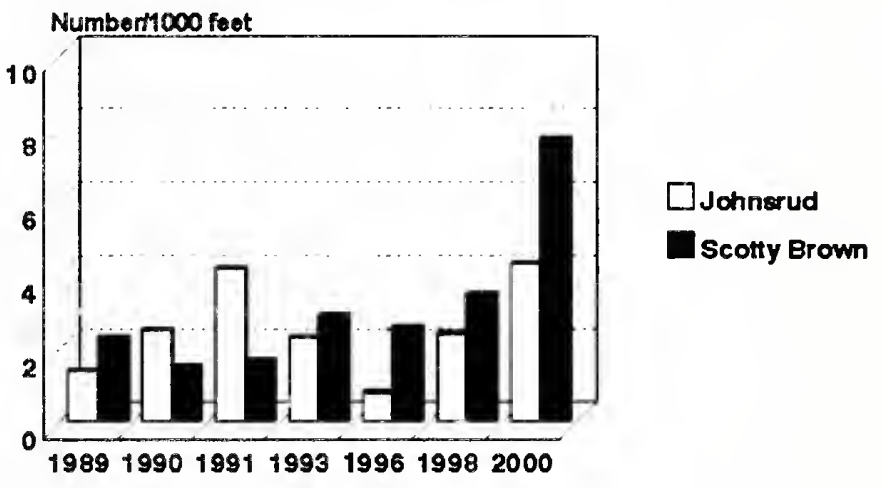

Figure 12. Estimated bull trout densities (fish $>6.0$ ") for two sections of the Blackfoot River, 1989-2000.

In 2000, we observed six northern pike in the Johnsrud section, compared to two in 1998 and one in 1996. In 1999, the lower Blackfoot River and Gold Creek-which enters the Johnsrud section, both tested positive for whirling disease for the first time. In 2000 , we observed clinical signs (cranial deformities) of whirling disease in $<5 \%$ of sampled rainbow trout.

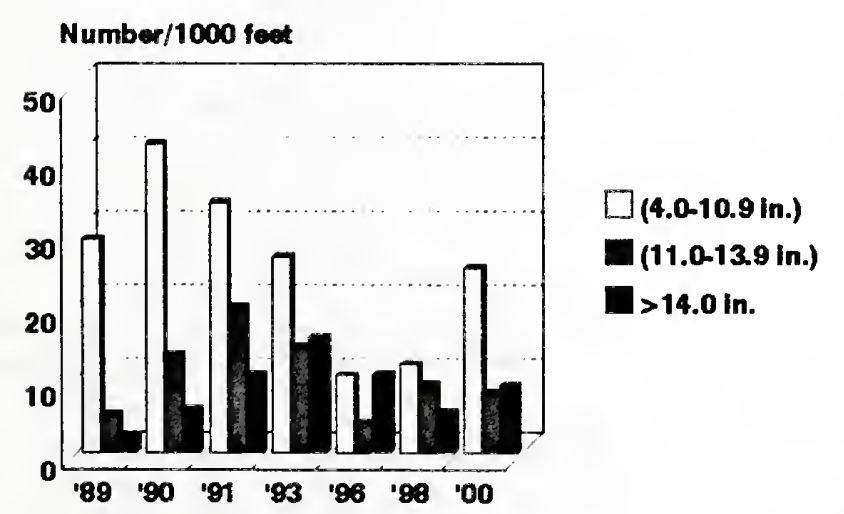

Figure 13. Estimated rainbow trout densities for the Scotty Brown Bridge section, 1989-2000.
Scotty Brown Bridge section

In May 2000, the percent trout composition for the total catch was $40.9 \%$ rainbow trout $(\mathrm{n}=349), 26.6 \%$ brown trout $(\mathrm{n}=227), 26.8 \%$ WSCT $(\mathrm{n}=228), 5.4 \%$ bull trout $(\mathrm{n}=46)$ and $0.2 \%$ brook trout $(n=2)$.

Estimated densities of bull trout (fish $>6.0$ ") increased from 3.5 to $7.7 \mathrm{fish} / 1000$ ' from 1998 to 2000 . Although still low, bull trout numbers in 2000 continued an upward trend in this river section (Figure 12). Likewise, WSCT densities (fish 
$>6.0^{\prime \prime}$ ) increased from 21.9 to 23.9 fish/1000' between 1998 and 2000 (Figure 3).

From 1998 to 2000 , densities of smaller rainbow trout $\left(4.0-10.9^{\prime \prime}\right)$ doubled from 12.0 to $25.1 \mathrm{fish} / 1000$ '. Rainbow trout in the intermediate $\left(11.0-13.9^{\prime \prime}\right)$ class decreased slightly from 9.3 to 8.2 fish/1000'. Densities of large rainbow trout (fish $>14.0$ ") increase from 5.6 to 9.2 fish/1000' (Figure 13).

The point estimate for smaller brown trout (6.0 - 12.0") increased from 6.7 in 1998 to 12.5 fish/1000' in 2000 . During this period, numbers of larger brown trout (fish $>12.0$ ") also increased from 6.7 to 11.5 fish/1000' (Figure 14).

The Scotty Brown Bridge section supports the highest recorded infection levels of whirling disease for the Blackfoot River (Pierce and Podner 2000). Cottonwood and Chamberlain Creeks, both whirling disease infected, enter the sampling section. At least three more

Number $/ 1000$ feet

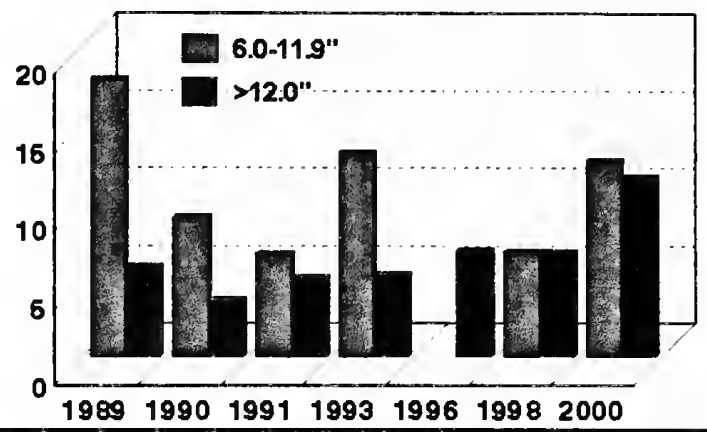

Figure 14. Estimated brown trout densities for the Scotty Brown Bridge section, 1989-2000. upstream tributaries (Warren, Kleinschmidt and Rock Creeks) are whirling disease positive. Between 5-10\% of rainbow trout captured in the Scotty Brown Bridge section showed clinical signs of the disease. Unlike the Johnsrud section, we have not observed northern pike in the Scotty Brown Bridge section. 


\section{PART II: FISH POPULATION INVESTIGATIONS IN GARNET MOUNTAIN TRIBUTARIES}

Results Part II outlines fish population inventory results for 22 Garnet Mountain streams (Figure 15). Tributaries in the Union Creek and Nevada Creek watersheds are organized beginning with the lower-most tributary and proceeding upstream. Tributaries outside of these two watersheds are organized alphabetically. Five additional Garnet Mountain streams (Bear Creek, Chamberlain Creek, Elk Creek, Pearson Creek and Nevada Spring Creek), all restoration project streams, are summarized in Results Part III.

In Part II, population summaries generally rely on a catch-per-unit-effort (CPUE) statistic. This refers to the number of fish collected in a single (or first) electrofishing pass and is adjusted per 100' of stream (i.e. CPUE of 8 means 8 fish captured per 100'). Additional catch statistics are in Appendix A and C.

For some charts in Results Part II and III, abbreviations delineate fish species; they are CT for westslope cutthroat trout (WSCT), DV for bull trout, LL for brown trout, EB for brook trout and RB for rainbow trout.

Figure 15. Location map of Garnet Mountain fish population survey sites.

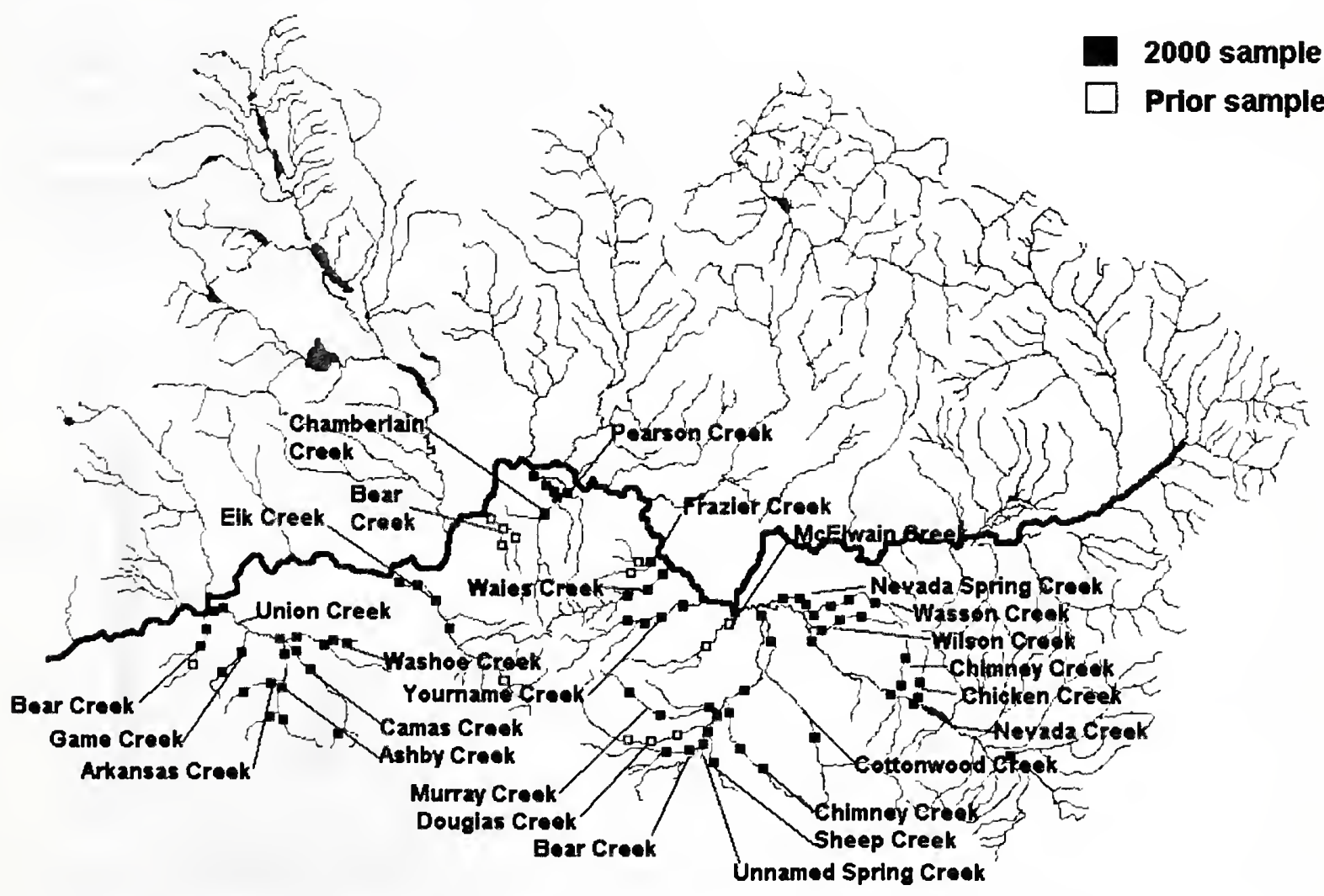




\section{Union Creek}

Union Creek, a primary $3^{\text {rd }}$ order tributary to the lower Blackfoot River entering at river mile 12.9 , originates from several headwater streams. In the upstream direction, principle tributaries are Game Creek (mile 4.0), Camas Creek (mile 7.6) and Washoe Creek (mile 13.5). Union Creek's mainstem flows in a northwestern direction, primarily though private ranch land with extreme headwater reaches on both Plum Creek and BLM land. Stream gradient in the headwater areas (upstream mile 10) average $196 \%$ mile compared to $24 \% / \mathrm{mile}$ downstream of mile 10 . We completed fish population surveys at five locations on Union Creek (miles 0.1, 0.2, 7.2, 9.1, and 16.5). A temperature sensor at mile 0.1 failed. We measured discharge at $0.3 \mathrm{cfs}$ at mile 0.8 on $8-24-00$ (Figure 16).

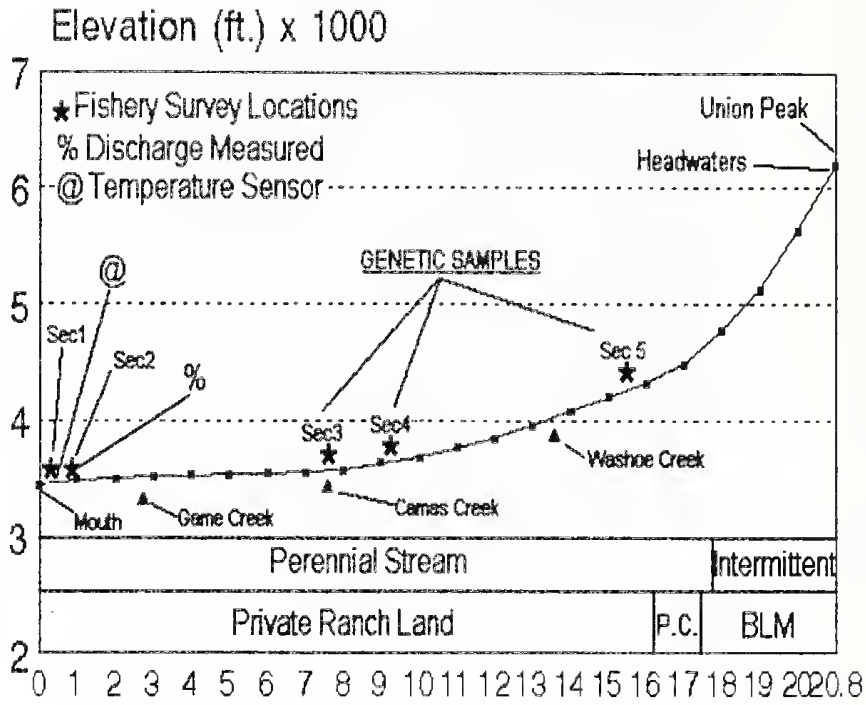

Stream Mileage

The uppermost survey section (mile 16.5) supports a generally healthy riparian area with an overstory of Douglas fir and larch above alder shrub layer. We found stable stream banks and sufficient instream wood. However, we also observed localized areas of excessive livestock use resulting in over-widened areas of the channel in the upper reach. We also identified an unscreened irrigation ditch (mile 15.2) which entrains WSCT according to the ranch manager on the property.

Survey sections at mile 9.1, the stream lacks complexity and appear to support elevated levels of fine sediment. At mile 7.2, the landowner is managing the stream for riparian health. At this location, Union Creek is vegetated with willow, alder and grasses. Fish habitat in this section consists of undercut banks and woody debris from alder and willow. This section of stream also appears to support elevated levels of fine sediment from upstream sources. The major substrate is sand and gravel.

Survey sections near the mouth recorded relatively healthy riparian vegetation despite channel alteration from Highway 200. Riparian vegetation consists of Douglas fir, ponderosa pine, alder, willow and grasses. Woody debris recruitment to the stream channel is minimal in

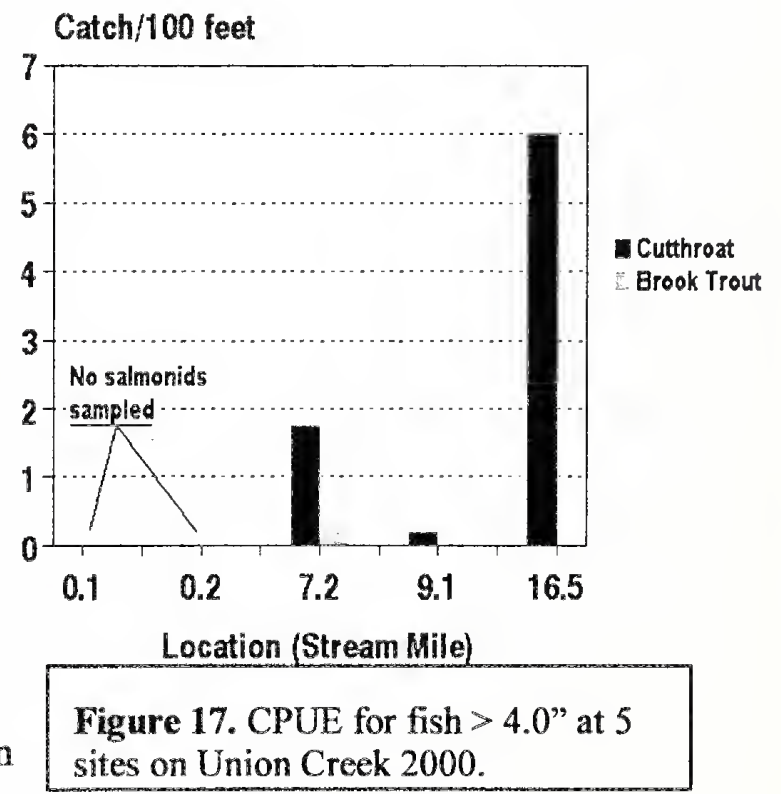


these two sections.

Problems on the mainstem of Union Creek relate to irrigation diversions with no fish passage consideration, chronic dewatering in low-to middle reaches. Portions of the lower channel have also lost shrub cover and bank stability, and appear to be in the process of becoming entrenched. Although several landowners have expressed a willingness to cooperate in riparian and fish population improvement projects, at this time, no organized efforts have developed in this watershed.

\section{Fish Populations}

We completed fish population surveys at five different locations on Union Creek (miles $0.1,0.2,7.2,9.1$, and 16.5) in 2000, two of which were duplicate sample sites established in 1989. WSCT and brook trout were salmonids present; both species were restricted to the mid- to upper reaches of Union Creek.

The highest numbers of WSCT were found at the upper survey site (mile 16.5) where the CPUE (fish >4") was 13.4 and 7.4 for YOY (Figure 17)

Sampling at mile 9.1 recorded much lower densities of WSCT compared to upand downstream samples. Similar to the 1989 survey conducted at this site, only one WSCT > 4" (CPUE of 0.2) was collected; we found no WSCT YOY at this location. Like the 1989 survey, we recorded the presence of other fish species that include sculpins, longnose suckers and red-side shiners. Furthermore, we also recorded the presence of tailed frogs in 2000.

At mile 7.2, we found much higher densities of WSCT (fish >4.0") compared to the upstream (mile 9.1) section. Sampling produced a CPUE (fish >4.0") for WSCT of 1.7 , a $40 \%$ increase compared to the 1989 survey. The riparian area at this location is well managed and healthy. Increased WSCT densities may be a function of improved habitat conditions, and/or WSCT recruitment sources possibly from Ashby Creek-a tributary stream to Camas Creek, which enters approximately 0.5 miles upstream of this sampling location. We also found very low densities of brook trout and the presence of longnose suckers.

At the two lower Union Creek samples (mile 0.1, 0.2) we found no salmonids but rather a species assemblage of longnose dace, longnose sucker, and redside shiner. We collected 25 WSCT genetic samples at the upper sample locations, the results of which are pending.

\section{Game Creek}

Game Creek, a $1^{\text {st }}$ order tributary, flows 5.6 miles to its junction with Union Creek at stream mile 4.0. Stream gradient ranges from $640 \%$ mile to $110^{\prime} /$ mile near the mouth. The upper 3.4 miles of stream flows through Plum Creek Timber Co. and State land before entering private ranch land near mile 2.0

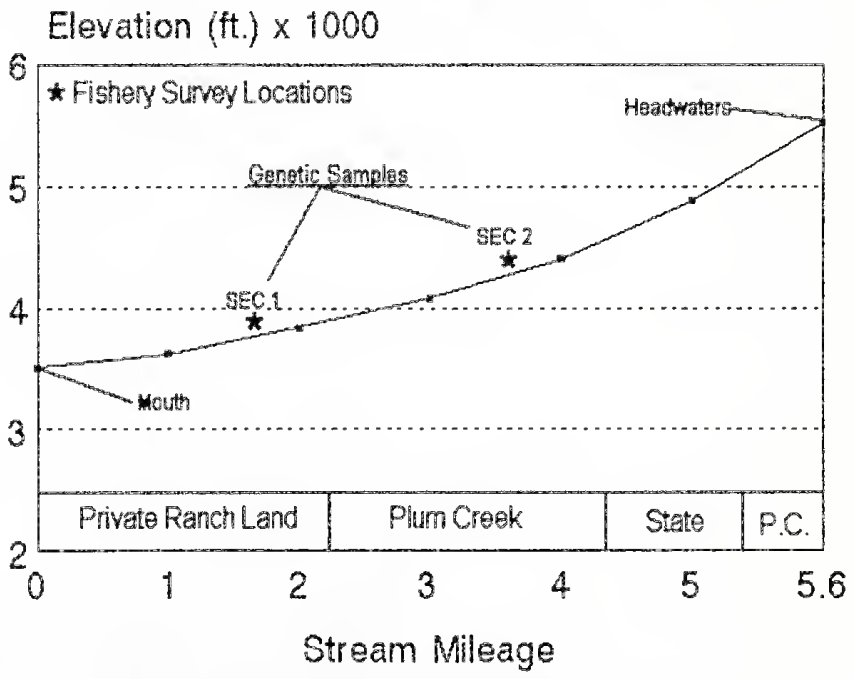

Figure 18. Longitudinal profile for Game Creek. 
(Figure 18).

Because we were denied access to lower reaches, we only conducted two surveys on Game Creek (mile 1.9 and 3.8).

At mile 3.8, the riparian community appears healthy, with a dense over-story of Douglas fir and ponderosa pine above an under-story of alder and hawthorn. We recorded stable stream banks along with adequate instream woody debris providing high quality fish habitat. The only problem observed at this site was a perched culvert.

At mile 1.9, we found a dense community of hawthorn, alder, and grasses stabilizing the streambank and providing a moderate amount of woody debris to the stream. Stream substrate consists of sand, gravel, and cobble with low levels of sediment. We observed a light amount of stream bank damage caused by livestock.

Fish Populations

In 2000, WSCT were the only species present in Game Creek with comparable densities at both sample locations (Figure 19). We found WSCT YOY at both locations with higher densities at the lower sampling site. Spotted frogs were present at both sampling locations. We collected 26 WSCT genetic samples the results of which are pending.

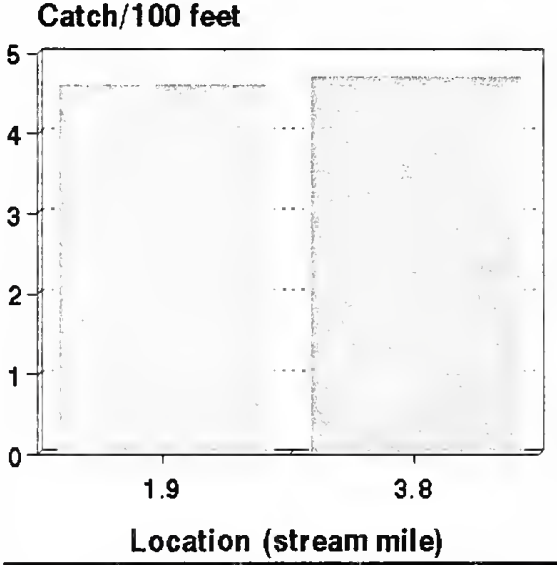

Figure 19. CPUE for WSCT (fish $>4.0$ ") at 2 sites on Game Creek 2000.

\section{Camas Creek}

Elevation (ft.) $\times 1000$

Camas Creek is a $3^{\text {rd }}$ order tributary to Union Creek entering at stream mile 7.6. Camas Creek begins on Plum Creek lands and flows 9.8 miles first through commercial timberlands before entering private ranchlands near mile 6.0. Stream gradient ranges from $480 \% /$ mile in the headwaters to $56 \%$ mile near the mouth. Smith Creek, a small headwater tributary, enters Camas Creek at mile 8.0 and provides the majority of inflows during base-flow

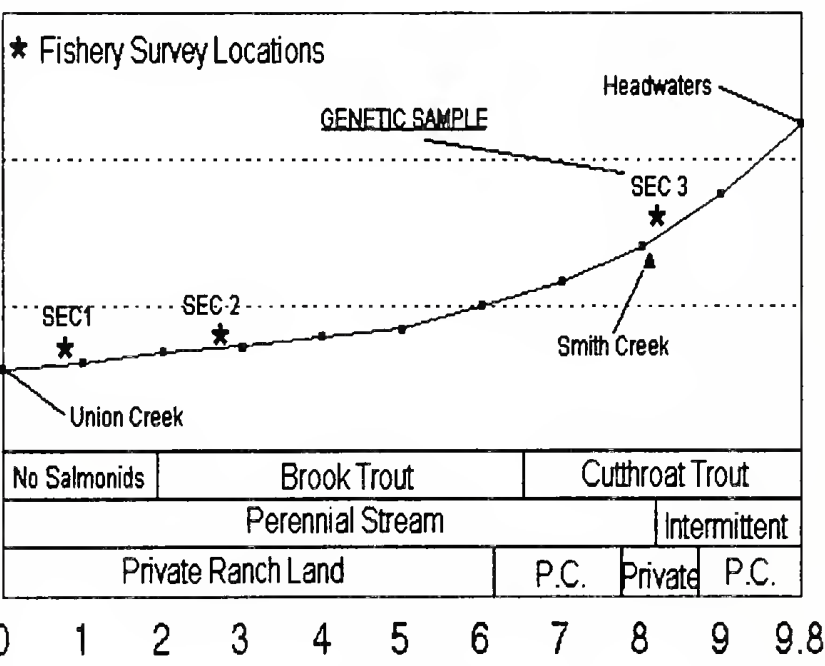
periods. Above the Smith Creek $^{0}$ confluence, Camas Creek is intermittent. We established two fish populations survey sites on Camas Creek (miles 0.9 and 2.9) and one site on lower Smith Creek (mile 0.1) (Figure 20). 
The upper survey site (Smith Creek-mile 0.1) is on a small section of undeveloped private land. Although we observed a few areas of livestock-related stream bank impacts, the overall condition of the riparian area appeared healthy. Both over-story and under-story provide shade, fish habitat, and moderate bank stability.

The two lower survey sections (mile 0.9 and 2.9) on Camas Creek were meandering meadow E-type channels. The riparian community consists of timothy and cut grass mixed with some bulrush and horsetail. At the upper Camas Creek survey site, we found unstable and sloughing banks resulting from excessive cattle use. A suppressed alder overstory provides limited bank stability and instream wood for fish habitat.

At the lower Camas Creek survey section; stream banks are stable where fenced and not subjected to livestock degradation. No riparian over-story exists; as a result, the stream channel lacks woody debris to provide fish habitat. Under-cut banks provide the only fish habitat. The substrate is sand and gravel with very high levels of sediment.

\section{Fish Populations}

The Camas Creek drainage supports WSCT, brook trout and sculpins. WSCT inhabit the headwaters, including Smith Creek (Figure 21). We found no WSCT in lower Camas Creek in 2000. Brook trout were present in very low densities at mile 2.9. We found no salmonids at the lower sample site-only sculpins. We collected 18 cutthroat genetic samples from the upstream sampling location; results are pending.

\section{Ashby Creek}

Ashby Creek is a $2^{\text {nd }}$ order tributary stream to Camas Creek entering at mile 0.5. Upper reaches flow predominately through forested areas including Plum Creek and BLM properties before entering private

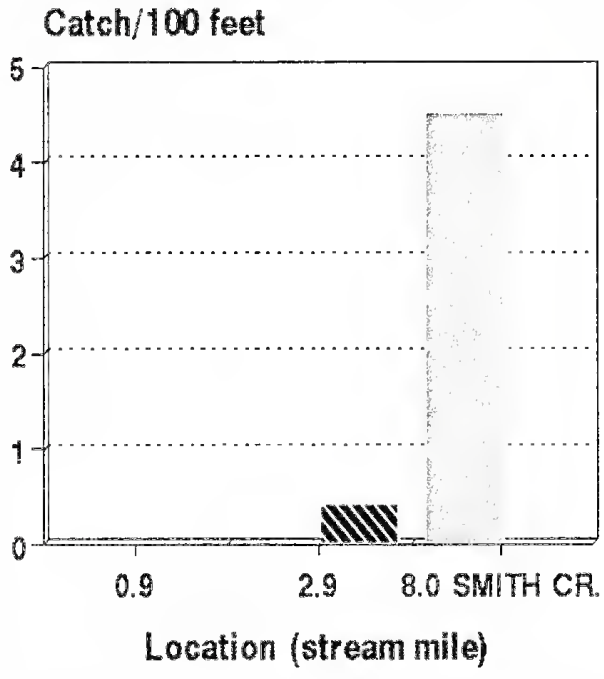

Cutthroal Trout

$N_{\text {Brook Trout }}$

Figure 21. CPUE for fish $>4.0$ "at 3 sites on Camas Creek 2000.

Elevation (ft.) $\times 1000$

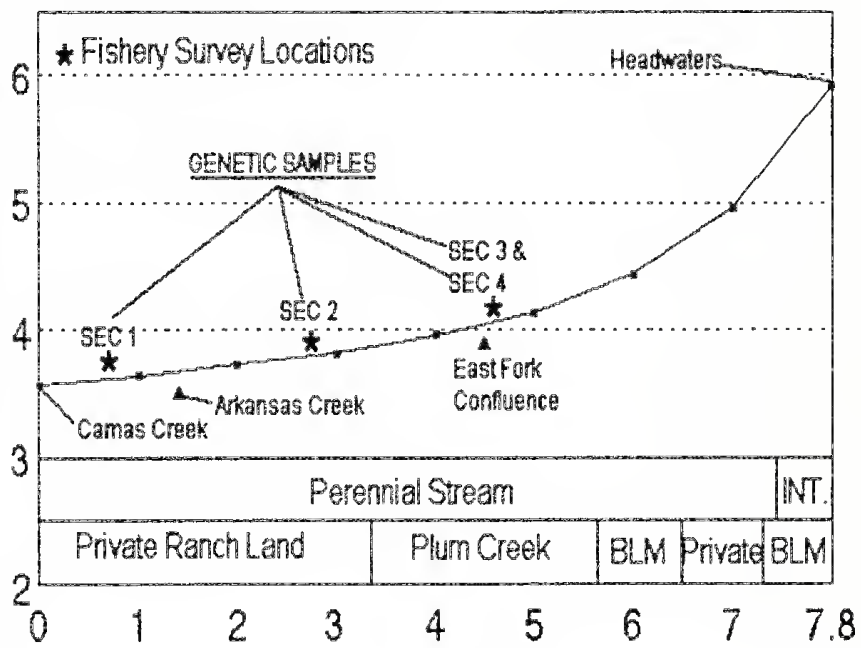

Stream Mileage

Figure 22. Longitudinal profile for Ashby Creek. 
ranchland near mile 3.0 (Figure 22). Stream gradient ranges from $960^{\circ} / \mathrm{mile}$ in the headwaters to $90^{\prime} /$ mile in lower reaches. In 2000 , we established four survey sections-three on the mainstem (miles 1.0, 3.0 and 4.8), and one on the lower East Fork of Ashby Creek (mile 0.1).

At the two upper survey locations, the riparian community consists of conifer woodland with alder and grass/sedge species in the understory. At stream mile 3.0, the stream enters a ponderosa pine, aspen and meadow environment with a well-managed and healthy riparian area. However, stream reaches immediate downstream of this sample section are severely degraded.

Near the lower survey site (mile 1.0), the riparian community consists of sparse grasses with an overstory of suppressed alder.

Identified problems include localized areas of riparian livestock overuse, sediment impacts related to both road problems and riparian livestock overuse.

\section{Fish Populations}

Our surveys show Ashby Creek support populations of WSCT and brook and no other fish species. WSCT is the dominant species with densities increasing in the upstream direction. The East Fork of Ashby Creek seems to

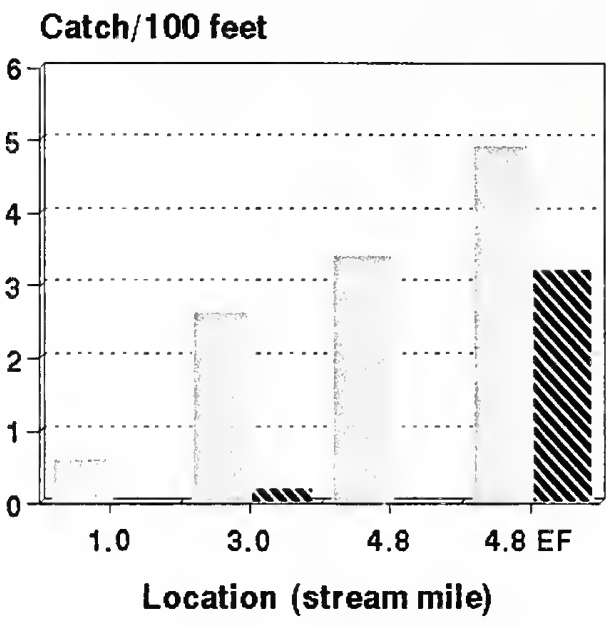

Figure 23. CPUE for fish $>4.0$ " at 4 sites on Ashby Creek and E. F. Ashby Creek 2000. support higher densities of both species compared to the lower mainstem of Ashby Creek (Figure 23). Densities of WSCT (fish $>4.0$ ") decline in the downstream direction with CPUE of 5.0 in the East Fork to 0.6 at the lower-most survey site (mile 1.0). Based on YOY surveys, it appears that the majority of WSCT reproduction occurs in the mid-to-upper reaches of the mainstem. Brook trout YOY were found only in the East Fork. We collected 25 WSCT genetic samples the results of which are pending. Amphibians observed included spotted frogs at the two lower sample sites.

\section{Arkansas Creek}

Arkansas Creek is a small $1^{\text {st }}$ order tributary stream to Ashby Creek entering at stream mile 1.4. Stream gradient ranges from $520 \% / \mathrm{mile}$ in the headwaters to $125^{\prime} / \mathrm{mile}$ in the lower reaches (Figure

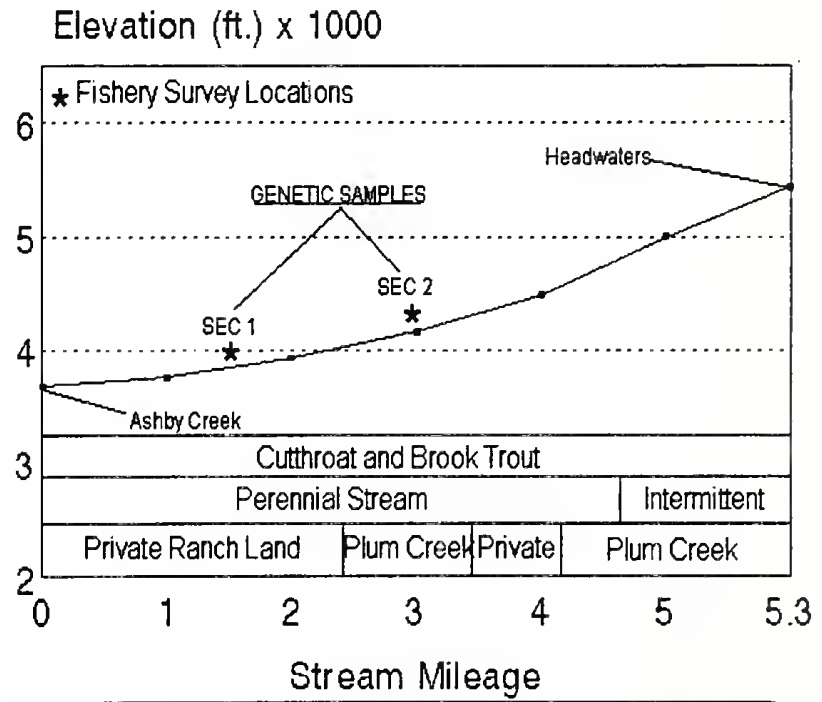

Figure 24. Longitudinal profile for Arkansas Creek. 
24). In 2000, we assessed riparian habitat and sampled fish populations in Arkansas Creek at two locations (miles 1.5 and 3.0).

Riparian habitats at both survey sites were generally in healthy condition although riparian grazing damaged localized areas of the upper riparian area. The upper survey section overstory consists of Douglas fir with a predominately grass and alder understory mixed with red osier dogwood. Ponderosa pine dominated the overstory of the lower survey section along with an alder/hawthorn understory.

The stream channel at both sites contains light to moderate amounts of woody debris, along with areas of undercut banks. Stream substrate consists of gravel and cobble with low levels of sediment at both sections.

Problems observed at the upper survey section include localized areas of livestock induced bank degradation (accelerated erosion and channel widening).

\section{Fish Populations}

Arkansas Creek supports low densities of WSCT and brook trout. We found no other fish species. Brook trout densities were at comparable low densities at both sampling locations. WSCT (fish $\left.>4.0^{\prime \prime}\right)$ densities increased in the upstream direction from a CPUE of 1.2 and 2.7 (Figure 25). In addition, we found YOY of both species present in low numbers. Amphibians present were spotted frogs and western toads at both sites. We collected 6 21 WSCT genetic samples the results of which are pending.

\section{Washoe Creek}

Washoe Creek, a $1^{\text {st }}$ order tributary, 4.5 flows 6.2 miles and enters upper Union Creek at mile 13.5. Washoe Creek is a small perennial stream that drains the north 3.5 slope of Union Mountain. Land ownership in the Washoe watershed varies from BLM and state land in the headwaters to private 2.5 ranchland in the lower basin (Figure 26).

In 2000 , we established two sample locations in Washoe Creek (miles 0.2 and 0.6 ) in lower reaches due to access restrictions to the headwaters. The riparian

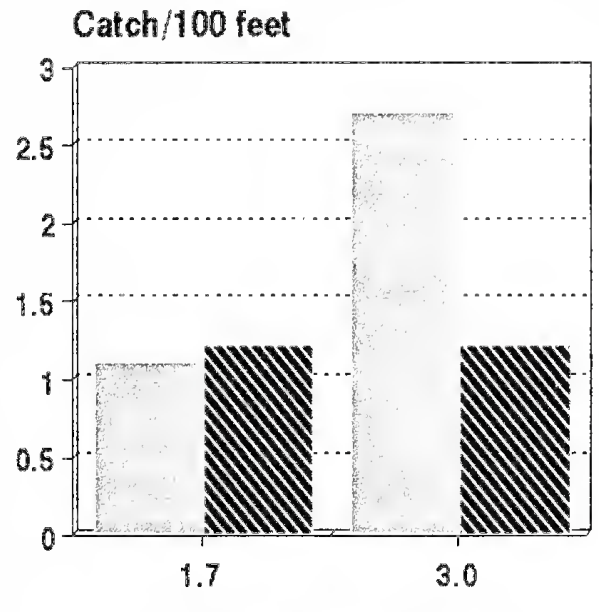

Location (stream mile)

Figure 25. CPUE for fish $>4.0$ " at 2 sites on Arkansas Creek 2000.

Elevation (ft.) $\times 1000$
Cutthroat Trout

N Brook Trout

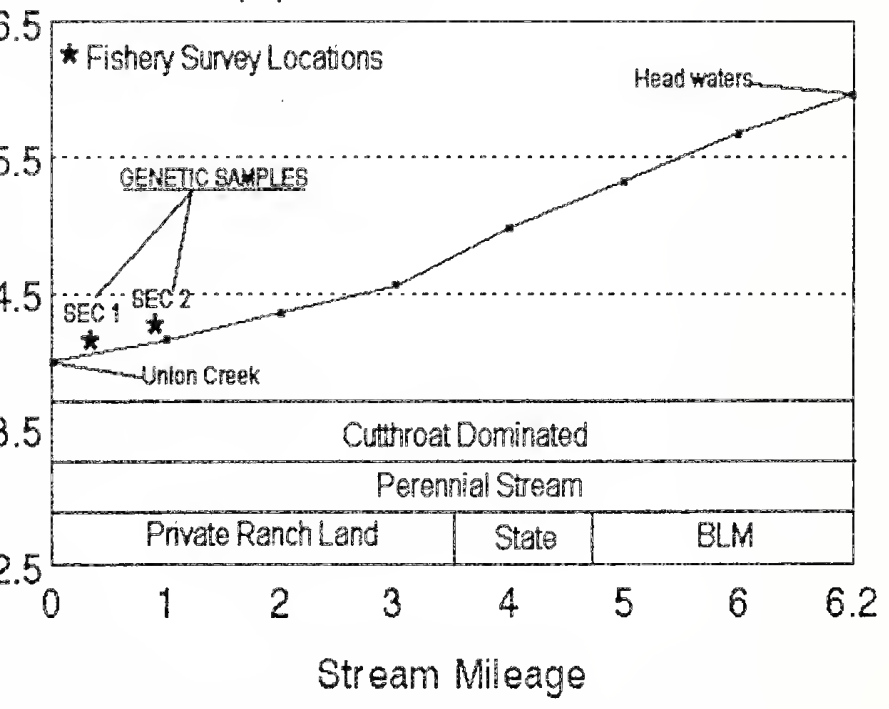

Figure 26. Longitudinal profile for Washoe Creek. 
habitats at both sites are similar-dense under-story of alder, hawthorn, timothy, and sedges with a moderate over-story of quaking aspen. Banks are stable; however, localized areas of degradation caused by cattle are present at the upper site. The stream channel at both sites lack woody debris. Fish habitat consists of overhanging vegetation and undercut banks. Both survey sites appeared to support elevated levels of instream sediment.

\section{Fish Populations}

Washoe Creek supports a native assemblage of WSCT and sculpins. The samples show comparable densities at both locations with a CPUE (Fish $>4.0^{\prime \prime}$ ) ranging from 5.1 and 5.7 fish/100' (Appendix A). We also recorded the presence spotted frogs. We collected genetic samples from 12 WSCT, the results of which are pending.

\section{Nevada Creek}

Nevada Creek, is a major tributary to the middle Blackfoot River entering at mile 67.8. Nevada Creek follows a sinuous course through a wide alluvial valley in its lower reaches. Downstream of Nevada Reservoir direct tributaries in the upstream direction are include McElwain Creek (see Pierce and Schmetterling 1999), Douglas Creek and Nevada Spring Creek, Wilson Creek, Chimney Creek and Chicken Creek (Figure 27). Historically, Nevada Creek was probably a beaver/willow complex, but has been converted to hay/grazing meadows, largely through the active control of beaver.

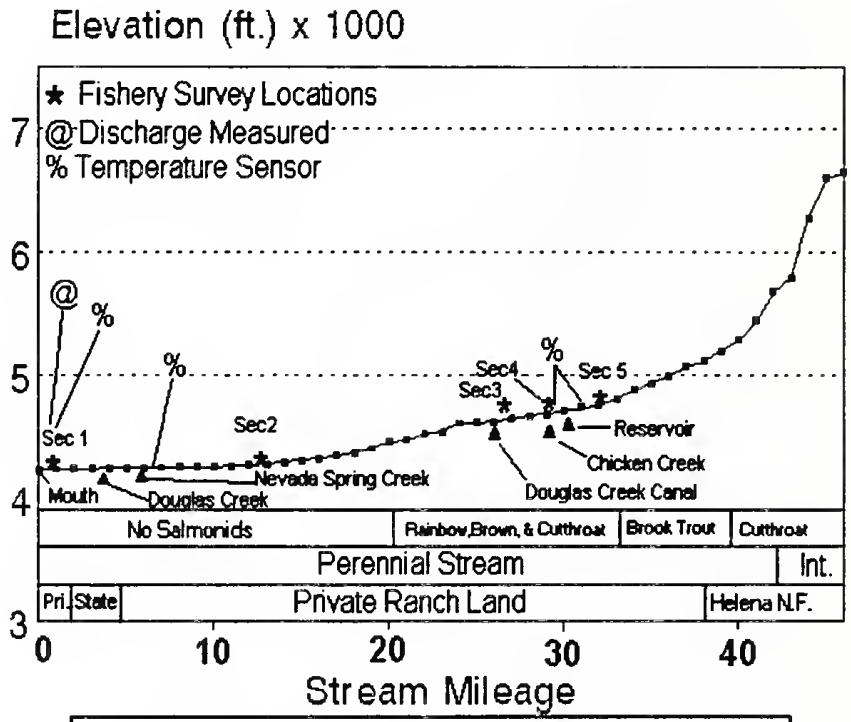
Nevada Creek contributes a significant amount of water to the Blackfoot River during low flow periods. On Aug.24, 2000 we measured the flow discharge at stream mile 0.3, recording $16.2 \mathrm{cfs}$. Unfortunately, Nevada Creek has poor water quality including high temperatures, high nutrient loading and high levels of sediment, all of which decrease water quality in the Blackfoot River below Nevada Creek (Ingman 1990, Pierce et al. 1997). Nevada Creek Watershed is also the site of a water quality improvement project, coordinated by the North Powell Conservation District in cooperation with the DEQ 319 program and the NRCS.

Water releases from Nevada Reservoir and the related management of large canals are managed with few fish population considerations (Pierce et al. 1997). Surveys in the Douglas Creek canal in 1998 and 1999 found up to nine species (WSCT, brown trout, rainbow trout, mountain whitefish, sculpin, largescale sucker, yellow perch, redside shiner and longnose dace) in the canal. Some of these species were several miles below the point of diversion. In addition, channel alterations, and grazing management all 
contribute to poor riparian health and water quality problems below the reservoir (Ingman et al 1990, Fitzgerald 1996).

In 2000, we surveyed fish populations at four historical survey sites. We also established a new fish population sample site upstream of the Douglas Creek canal diversion. Temperature monitoring on Nevada Creek occurred at four locations (mile 0.3-mouth area, mile 7.0-upstream of Nevada Spring Creek, mile 29.0-below Nevada Creek reservoir, and mile 31.0-upstream of Nevada Reservoir) over the summer period. Only the temperature sensor below the reservoir did not exceed $70^{\circ} \mathrm{F}$. Maximum July stream temperatures increased $9^{\circ} \mathrm{F}$ between the reservoir $\left(68.4^{\circ} \mathrm{F}\right)$ and the mouth $\left(77.4^{\circ}\right.$ F). In 2000 , stream temperatures below the reservoir were $2.8^{\circ} \mathrm{F}$ higher than the maximum summer temperature for 1999.

Near the mouth of Nevada Creek, temperatures were consistently $>70^{\circ} \mathrm{F}$ during the summer period. Two major tributaries to Nevada Creek (Nevada Spring Creek and Douglas Creek) both contribute to warming problems in lower Nevada Creek; both consistently exceeded $70^{\circ} \mathrm{F}$ during the summer period (Appendix I).

\section{Fish Populations}

In 2000, we re-sampled three historical survey sections (mile 0.3, 12.5 and 29.0) downstream of the reservoir. We also established a new population survey site adjacent to the Douglas diversion (mile 27.0). For these samples, we collected catch statistics only for trout species, and classified the presence of non-game species by abundance rating (common, uncommon, rare, etc.)

At sample locations (mile 27.0 and 29), we found generally low densities of rainbow trout, brown trout and WSCT (Appendix A). However, at mile 29.0 we recorded an in rainbow trout (fish >4.0") with a CPUE of 3.6 in 2000 compared to 0.7 in 1994. These may be hatchery fish flushed downstream from the reservoir. This section also produced low densities (CPUE of 0.4) of large brown trout, mountain whitefish (abundant), sculpins (common), red-side shiners (uncommon) and large scale suckers (abundant).

At the mile 27.0-survey site, we found lower densities of WSCT, rainbow trout, and brown trout, compared to the upstream site. Red-side shiners are abundant in this section. As in 1994, the mile 12.5 sample recorded no salmonids, and similar results for non-game species. At stream mile 0.7 , we sampled low densities of mountain whitefish and common numbers of large-scale suckers.

\section{Douglas Creek}

Douglas Creek, a $3^{\text {rd }}$ stream, drains the largest sub-watershed in the southern region of the Nevada Creek watershed. The mainstem flows 22 miles in a northwest direction before and entering Nevada Creek at mile 4.4. Direct tributaries in the upstream direction are Cottonwood Creek (mile 1.2) Chimney Creek (mile 9.8) Murray Creek (mile 10.6) and Sturgeon Creek (mile 11.6). Douglas Creek originates on BLM and Plum Creek properties before passing though private ranchlands in mid-to lower reaches. Stream gradient ranges from $600 \% /$ mile in headwaters to a very low $5 \% /$ mile near the mouth. In 2000 , we re-surveyed three previously established fish populations survey 
sections (0.3, 8.0, and 11.2) (Pierce et al 1997, Pierce and Schmetterling 1999). We measured stream discharge of $1.2 \mathrm{cfs}$ at stream mile 0.3 at on 8-2-00 (Figure 28).

Douglas Creek has obvious riparian health problems, some of which extend into the tributaries. Perhaps the most Elevation (ft.) severe problem is vertical incision6,500 of the channel and lateral erosion of unstable vertical banks. Past 6,000 channel alterations, related to $\mathrm{road}_{5,500}$ construction, explains some of these adverse channel adjustments5,000 (Rosgen, communication). From our 20004,500 inventory, we also identified 1) Mouth excessive livestock damage to 4,000 immediate stream banks, 2) 3,500 elevated levels of fine sediment at
all sampling locations, 3) limited 3,000 instream wood and bank cover and 4) a general lack of habitat complexity. We identified suppressed shrub communities but also the presence of willow, alder, dogwood, juniper, wild rose, and

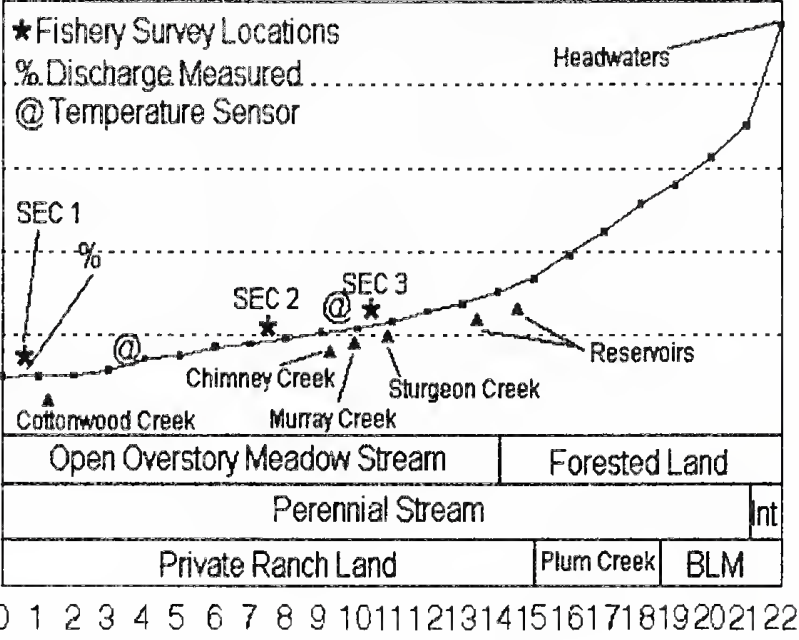

Stream Mileage gooseberry along with timothy, thistle, cut and rye grasses, horsetail, lurid sedge and bulrush as species present in the Douglas Creek riparian area. According to Dave Rosgen (personal communication), sections of incised (F-type) Douglas Creek channel are now evolving to more stable ( $\mathrm{C}$ and $\mathrm{E}$-type) channel types. These channel types are typically stabilized with extensive riparian and wetland vegetation that forms densely rooted sod mates from grasses and grass like plants, as well as woody species (Rosgen 1996).

Temperature monitoring on Douglas Creek occurred over a four-month period at two locations (miles 3.7 and 9.8). Both sites recorded maximum summer temperatures in August in the mid- to upper 70s (Appendix 1). Reservoirs in the upper basin contribute to downstream warming trends (Pierce and Schmetterling 1999).

\section{Fish Populations}

Comparing 1994 and 1997 survey results to those in the 2000, we found similar results, no fish at stream mile 0.3 , and only redside shiners, long-nose dace, and longnose suckers at stream miles 8.0 and 11.2. We found no salmonids at any of the sites, as opposed to, one westslope cutthroat recorded in 1997 at mile 11.2. We observed no amphibians at any of the 2000 Douglas Creek survey locations. 


\section{Cottonwood Creek}

Cottonwood Creek is a $2^{\text {nd }}$ order tributary to Douglas Creek entering a stream mile 1.2. Cottonwood Creek: begins on BLM land and checkerboard ownership before entering private ranchland in the middle reaches. Stream gradient ranges from $173 \%$ mile in the headwaters to $63 \%$ mile near the mouth. In 2000, we re-surveyed an upper fish population survey site at mile 10.1 (Figure 29). Because of dewatering, we were unable to sample the middle reaches of Cottonwood Creek. Discharge measurement collected at stream mile 2.4 recorded a flow of 0.04 cfs on 8-2-00.

We found a healthy riparian area at

Elevation (ft.) $\times 1000$

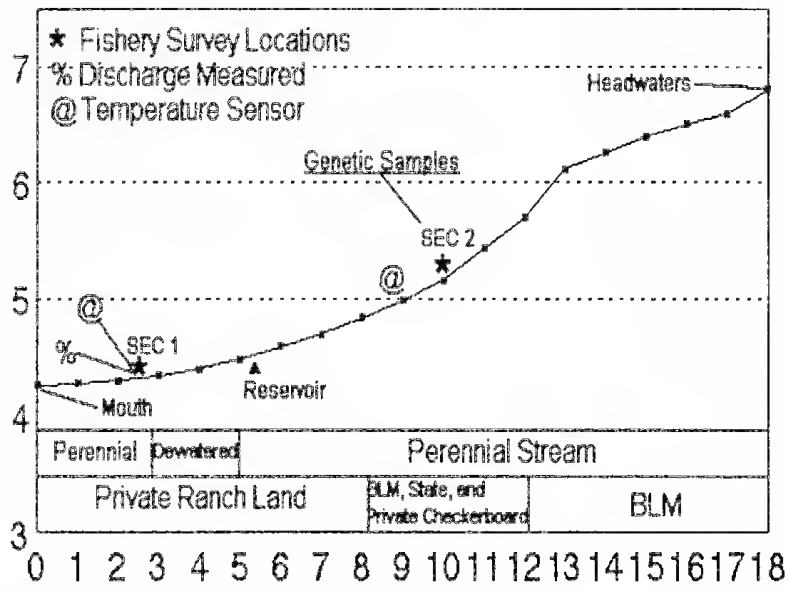

Stream Mileage

Figure 29. Longitudinal profile for Cottonwood Creek.

the upper survey site, which included an overstory dominated by Douglas fir above an understory of Douglas fir regeneration, rocky mountain maple, alder, and a diverse herbaceous flora community. Woody debris is abundant, providing suitable fish habitat. Stream substrate in this section is predominately gravel and cobble, but some boulders are present creating pocket pools for fish. Cattle grazing occur but appear to be well managed with minimal impacts to the stream.

In contrast, the riparian area at the lower survey section lacks complexity. The plant community consists of a sparse willow overstory of willow above an under-story of lurid sedge, bulrush, and timothy. The stream channel lacks woody debris. Problems in the lower survey section relate to dewatering, areas of livestock-related bank degradation including over-widening of the stream channel and resulting heavy sediment load of 3-6" in the channel.

Cottonwood Creek contributes to temperature problems in Nevada Creek. The lower Cottonwood Creek (mile 2.4) temperature sensor recorded maximum July and August temperatures of $74.5^{\circ} \mathrm{F}$. (Appendix I).

\section{Fish Populations}

\section{Cottonwood Creek support} populations of cutthroat and brook trout; both species are restricted to the headwaters (Figure 30).

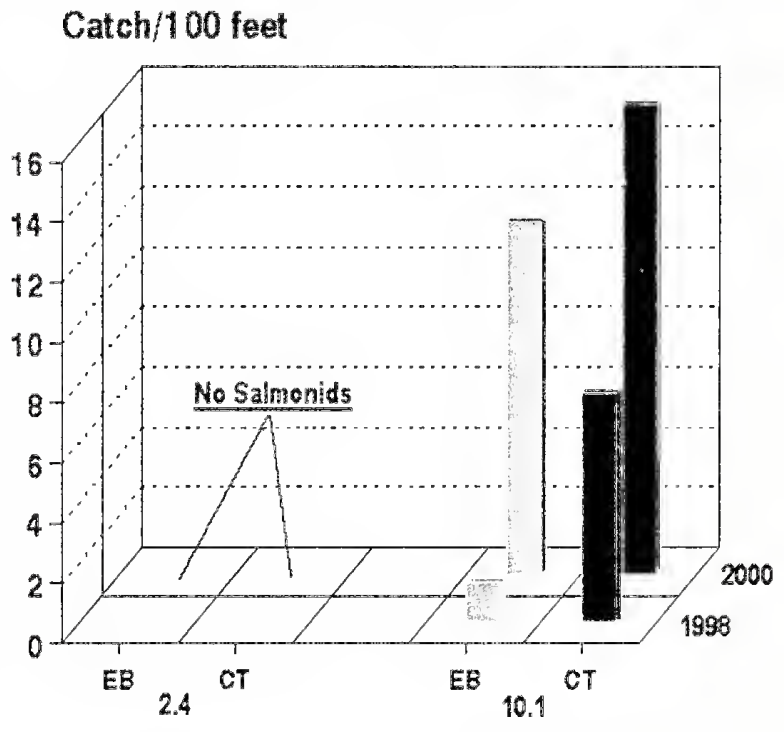

Figure 30. CPUE for fish $>4$ " at 2 sites on Cottonwood Cr. 2000. 
In 2000, we sampled fish populations at two locations (mile 2.4 and 10.1). The upper sample was a duplicate-sampling site established in 1998. At the mile 10.1 fish population survey section, the CPUE for WSCT (fish > 4") increased from 7.6 in 1998 to 15.6 fish in 2000. The CPUE for WSCT YOY also increased from 3.0 to 11.5. Brook trout showed similar increases. At the lower sample location (mile 2.4), fish species observed were long nosed suckers. We also observed spotted frogs at this location. We collected 25 WSCT genetic samples at mile 10.1, the results of which are pending.

Chimney Creek

Elevation (ft.)

Chimney Creek, a $1^{\text {st }}$ order tributary stream to Douglas Creek, drains Chimney Mountain, Chimney Lakes and North and South Chimney peaks. Chimney Creek's entire 7.4mile length flows through private 4,500 ranchlands. Stream gradient ranges from $360 \%$ mile to $60 \%$ mile at its 4,000 confluence with Douglas Creek at mile 9.8. There are two instream irrigation reservoirs on Chimney Creek (mile 0.8 and 3.2). In July 2000 , we established fish population survey sites at three locations: an upstream survey site (mile 3.5 ) above of the upper reservoir; a middle

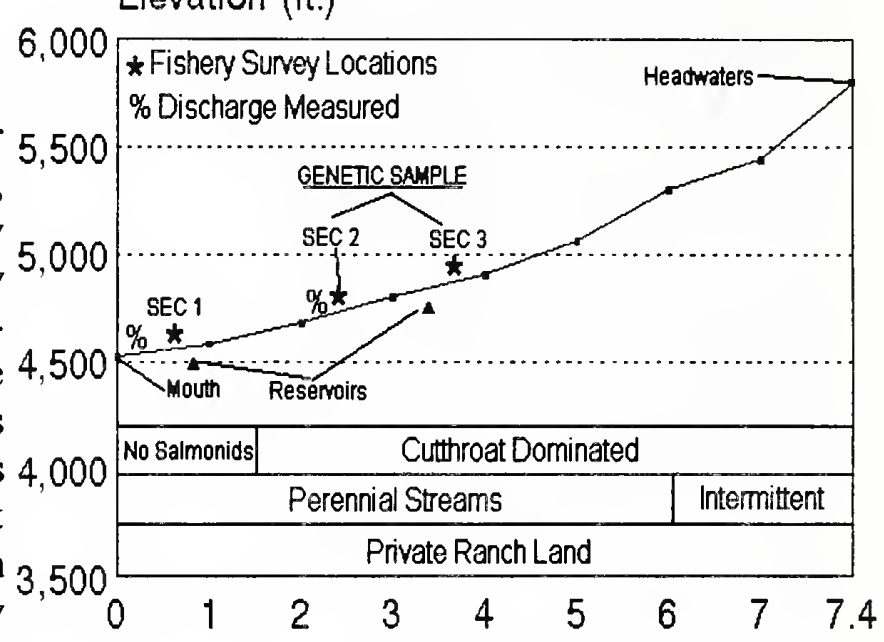

Stream Mileage survey (mile 2.5) between the reservoirs; and a lower survey (mile 0.7 ) downstream of the lower reservoir (Figure 31).

Riparian conditions at both upper survey sites were generally healthy. A healthy understory of rose, alder, willow and red osier dogwood helps maintain bank stability. An overstory of Douglas fir is providing shade and woody debris to the stream. Streambank grasses include a mixture of timothy, rice-cut grass, clover, and horsetail. Sediment levels appear to be light.

Surveying the riparian habitat at the lower site (mile 0.7), we found severe livestock-related impacts including degraded stream banks, over-widened channels, areas of heavy sediment load, and overgrazed riparian vegetation. The release of top water from the reservoir directly upstream contributes to elevated water temperatures at this lower site. We recorded a temperature of $71^{\circ} \mathrm{F}$ at this lower site at the time of the survey compared to the $54^{\circ} \mathrm{F}$ recorded at the second site, upstream 1.8 miles. Overhanging alders and willows along with old fence post in the stream created some fish habitat.

Stream discharge measurements at mile 2.5 was $0.7 \mathrm{cfs}$ and $0.4 \mathrm{cfs}$ at the mouth on 7-11-00. 
Fish Populations

WSCT was the only salmonid found in Chimney Creek with distribution restricted to the mid-to upper reaches.

Sampling at both upper sites (mile 2.5 and 3.5 ) recorded very low WSCT densities with a CPUE (fish $>4.0^{\prime \prime}$ ) ranging from 0.9 at the upper sample (mile 3.5) to 0.7 at mile 2.5 (Figure 32). We found WSCT YOY at both upper-sampling locations. We also observed spotted frogs and western toad at both sites. We collected 11 WSCT genetic samples from the two upper sites, the results of which are pending. We found no WSCT at the lowermost sampling site. At this site, Chimney Creek supports an assemblage of

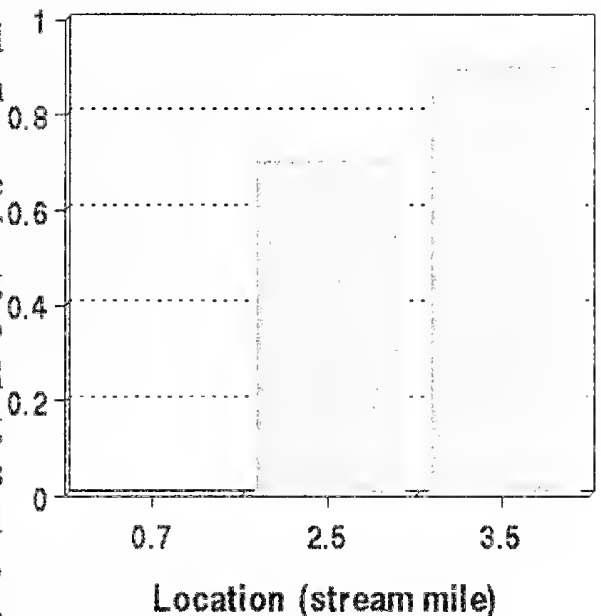

Cutthroat Trout non-game native species including redside shiners, longnose dace and longnose suckers (Appendix A).

\section{Murray Creek}

Murray Creek, a $2^{\text {nd }}$ order tributary, supplied a flow of $0.5 \mathrm{cfs}$ to Douglas Creek on 7/11/00. Murray Creek flows 8.2 miles through the foothills of the Garnet Mountains before entering Douglas Creek at stream mile 9.8. The upper Murray Creek drains land administered by the BLM before entering private ranchland in the lower basin. Stream gradient ranges from $500 \%$ mile in headwaters to $117 \%$ mile near 4 the mouth. In 2000, we established three survey sections (miles $0.1,3.3$, and 5.4) on Murray Creek, in addition to an irrigation ditch located at mile 3.7 (Figure 33). At the upper survey location (mile 5.4), we found a healthy riparian area, consisting of a Douglas fir and lodgepole pine over-story with an under-story of alder, and bank

Elevation (ft) $\times 1000$

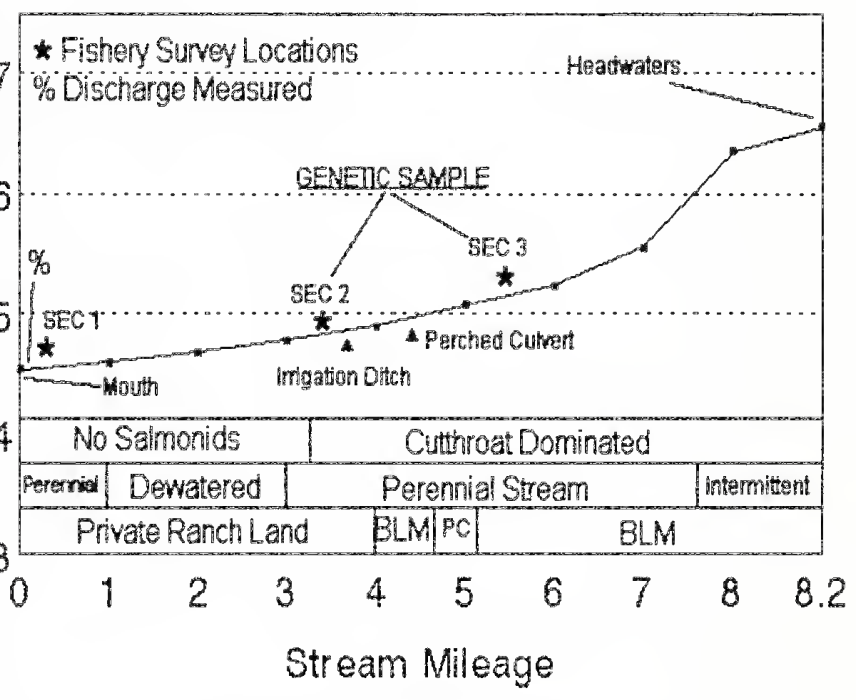

Figure 33. Longitudinal profile for Murray Creek. vegetation of snowberry, gooseberry, clover, and large amounts of horsetail. Murray Creek at this site possesses high amounts of woody debris, creating plunge pools for fish habitat. Substrate in this section consists of gravel and cobble.

At mile 3.3, Murray Creek is a meandering meadow stream with an unhealthy riparian area. Areas of bank erosion from livestock use are severe, creating a shallow 
over-widened stream with a heavy sediment load. This section of the stream has no overstory. Bank vegetation is comprised of timothy, clover, and dead alders. The channel lacks woody debris.

The lower survey site (mile 0.1 ) meanders through a meadow and has a relatively healthy riparian area compared to the upstream survey section. Riparian vegetation in this section is composed of willow and alder, above a mixture of timothy and bulrush. The stream channel contains moderate amounts of small woody debris. Livestock-related impacts were light to moderate in this section.

Other problems we observed include a pair of perched culverts (1'-2') acting as fish barriers at stream miles 3.2 and 4.3. In addition, Murray Creek downstream to the confluence of Fivemile Creek (mile 2.5 and 0.9 ) is dewatered from irrigation.

Fish Populations

WSCT, the only salmonid present in 7 Murray Creek sampling, is restricted to 6 headwater areas. At the upper sample location (mile 5.4), we recorded a $\mathrm{CPUE}^{5}$ (fish $>4.0$ ") of 6.4 and 3.5 for YOY (Figure 4 34). Sculpins were also present in this 3 section.

At mile 3.3, WSCT densities showed a sharp decline with a CPUE (fish $>4.0^{\prime \prime}$ ) of $0.2^{1}$ and 1.5 for YOY.

The fish population sample near the mouth of Murray Creek (mile 0.1) surveyed no salmonids; we recorded a common occurrence of redside shiners, longnose dace and the presence of sculpins.

Catch/100 feet

We netted one cutthroat in a 558' section of the irrigation ditch at stream mile 3.7. We collected 25 genetic samples from the two upper survey sites, the results of which are pending.

\section{Sturgeon Creek}

Sturgeon Creek, a $3^{\text {rd }}$ order tributary flows 4.2 miles though private ranch land to its confluence with Douglas Creek at stream mile 11.6. An irrigation reservoir is located below the junction of Bear Creek (mile 1.9). Mean stream gradient is $43 \% / \mathrm{mile}$. We recorded stream discharge at $0.1 \mathrm{cfs}$ at mile 0.1 on 7-6-00. We established two fish population survey sections on Sturgeon Creek (mile 0.1 and 1.8); both were located below the reservoir. We also surveyed a small, unnamed spring creek tributary to Sturgeon Creek at mile 0.1. This spring creek enters upstream of the reservoir at mile 2.6 (Figure 35) 
At the upper survey site (mile 1.8), Sturgeon Creek slowly meanders through meadows. The riparian area is healthy Elevation (ft.) with a community of willow, dogwood, 5,500 timothy, thistle, and several sedge species that provide for stable stream banks. The channel in this section 5,000 contains no woody debris, for fish habitat. Many areas of the predominantly sand and gravel substrate are covered with a heavy sediment load of 6" or deeper.

Sturgeon Creek, at the lower sampling location (mile 0.1), is a slow, deep meandering meadow stream with a healthy riparian area. Streamside vegetation consists of dogwood, wild rose, bulrush, and timothy. We observed a series of beaver dams beginning in this section. This section of streams lacks woody debris, other than beaver deposits. Signs of *Fishery Survey Locations

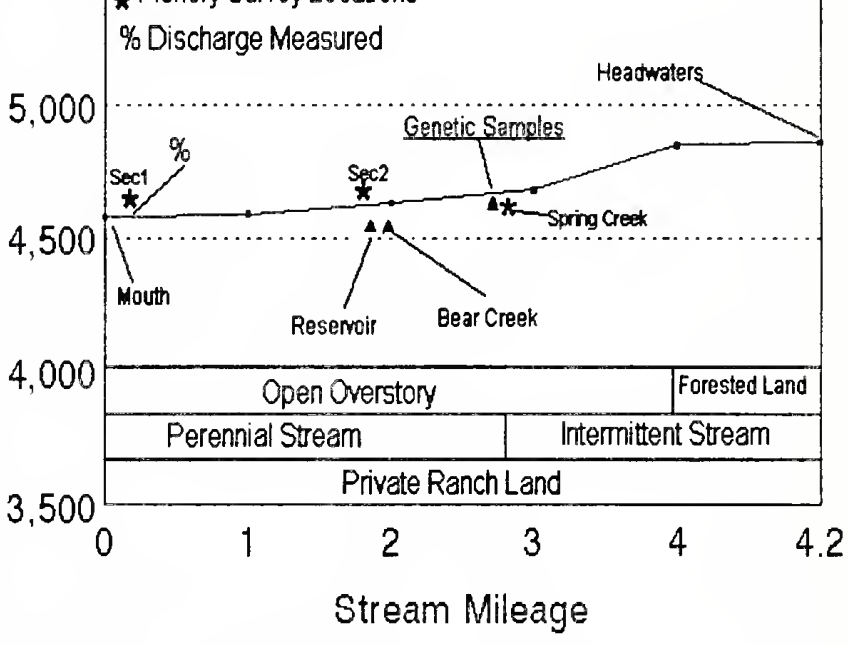
excessive cattle use were not evident.

In addition to Black Bear Creek, the unnamed spring creek was the only source of flow into Sturgeon Creek above the reservoir during our sampling. The spring creek at the sampling location (mile 0.1) is in poor condition from excessive livestock access to the stream; however upstream sections of the spring creek are improving due to grazing management changes.

\section{Fish Populations}

We found no salmonids in our samples of Sturgeon Creek. Redside shiners were the only species identified below the reservoir. However, upstream of reservoir, the spring creek supports a small disjunct population of WSCT. This population extends from the spring creek to the reservoir near mile 2.0 on Sturgeon Creek according to the landowners. The CPUE for WSCT in the unnamed spring creek was 2.7 (fish $>4.0$ ") and 0.8 for YOY. We observed spotted frogs at Sturgeon Creek and at the spring creek. We collected genetic samples from 18 WSCT in the spring creek, the results of which are pending.

\section{Sheep Creek}

Sheep Creek is a $1^{\text {st }}$ order tributary to Sturgeon Creek, located in the Douglas Creek Watershed. Sheep Creek flows its entire 4.2-mile length through private ranch land before entering Sturgeon Creek at mile 1.2. Stream gradients vary from $755^{\prime} / \mathrm{mile}$ and $135^{\prime} /$ mile near the mouth. We found the lower 2.6 miles of Sheep Creek degraded from excessive livestock access and dewatered due to the summer drought conditions. The riparian area contains lodgepole pine, Douglas fir, alder, and grasses grazed too low to identify. Sampling on this stream occurred at only one location (mile 2.8). 
Fish Populations

Sampling in Sheep Creek produced no fish.

\section{Black Bear Creek}

Black Bear Creek is a small $1^{\text {st }}$ order tributary stream to Bear Creek a $2^{\text {nd }}$ order tributary to Sturgeon Creek. It enters Bear Creek at stream mile 0.4. On July 10, 2000, Black Bear Creek was dry above mile 3.0, but we did measure a base-flow of $0.2 \mathrm{cfs}$ near the mouth. Black Bear Creek flows through mixed land ownership. Its headwaters begin on BLM land and flow eastward through Plum Creek Timber Co. land and then through private ranchland to its confluence with Bear Creek. Stream gradient ranges from $350^{\prime} / \mathrm{mile}$ to $50^{\prime} / \mathrm{mile}$ at its mouth. We established two survey sites on Black Bear Creek (mile 0.1 and 2.5).

Many areas of the stream banks on lower Black Bear Creek were unstable from livestock use. The riparian habitat has an overstory of predominately willow above a community of timothy, bull and spike-rush, rice-cut grass, and lurid sedge; however, most of the grasses were too over-grazed to identify. Other problems observed included over-widening of the stream channel, heavy sediment load, and over-grazing and suppressed willows. Furthermore, at approximately stream mile 2.8 , we observed an under-size road culvert perched $1.5^{\prime}$ on the downstream end and crushed on the upstream end. The crushed end of the culvert is forcing the water current to erode the banks and under-cut the road.

\section{Fish Populations}

We found no fish in Black Bear Creek. Spotted frogs are common and we observed one western toad.

\section{Wasson Creek}

Wasson Creek, a $1^{\text {st }}$ order tributary flows 8.4 miles first through Helena National Forest before entering private ranchland near mile 4.1. Wasson Creek enters Nevada Spring Creek immediately below its spring source (mile 3.2). Stream gradients vary from $1,140^{\prime} / \mathrm{mile}$ in headwaters to $10^{\prime} /$ mile near the mouth. In 2000 , we sampled fish populations at 4 locations $(0.9,2.4,3.7$, and 5.7), two of which we established in 1991 (Figure 36). We also sampled an irrigation ditch located at mile 2.4. We measured stream discharge $0.08 \mathrm{cfs}$ at mile 1.2 on 8-17-00.

We placed a temperature sensor at the Highway 141culvert (mile 1.3) crossing.

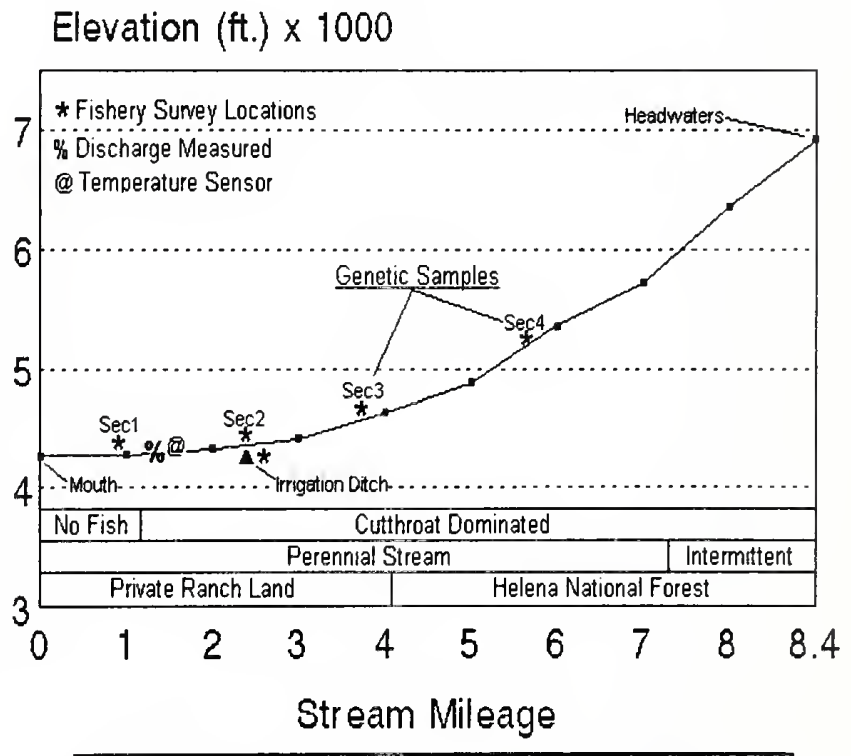

Figure 36. Longitudinal profile for Wasson Creek. 
recorded a summer maximum temperature of $67^{\circ} \mathrm{F}$ in August (Appendix I).

At the upstream sampling location (mile 5.7), Wasson Creek is a high gradient stream with a boulder, cobble, and gravel substrate. The riparian areas consists of Douglas fir, lodgepole pine and cottonwood overstory above a dense layer of snowberry, gooseberry, thimbleberry, clover, horsetail along with high concentrations of various mosses covering the banks. This section contains high quality fish habitat.

The survey section at mile 3.7 is in a transition reach between the high gradient National Forest reach and the low gradient meadow reach. At this site, we found an unhealthy riparian area due to excessive livestock access to the stream. Problems include over-widened and shallow channels, accelerated erosion rates and elevated levels of instream sediment. Riparian vegetation consists of primarily alder and suppressed willow. Understory species were heavily grazed and difficult to identify. We identified up-welling areas here. Stream temperatures were $10^{\circ} \mathrm{F}$ cooler than at the three downstream survey sites.

The mile 2.4 survey section, located below an irrigation diversion, is a meandering meadow stream with relatively stable banks and a healthy riparian area. Livestock related impacts were light. Riparian vegetation is comprised of alder, hawthorn, timothy, cutgrass, lurid sedge, and horsetail. Substrate in this section is mainly gravel with areas of moderate to heavy sediment accumulations.

The lower sampling site (mile 0.9 ) contains a relatively healthy meandering meadow stream with stable banks. The riparian community is a dense mix of dogwood, alder, willow, and Russian olive along with timothy, bulrush, lurid sedge, and mixed grasses. Mild cattle degradation occurs in areas of cattle crossings. The stream channel harbors high amounts of woody debris and a high sediment load from upstream sources.

We also identified an irrigation diversion near the mouth of Wasson Creek, which when in use may form a seasonal barrier to fish movement to and from Nevada Spring Creek.

\section{Fish Populations}

WSCT was the only fish species found in the 2000 Wasson Creek samples; however, brown trout are known to occupy the mouth area (Pierce et al. 1997).

The current WSCT population is restricted to the mid- to upper stream reaches. We found no fish in the two lower sampling locations although both WSCT and brown trout were present at these locations in 1991 (Pierce et al. 1997). In 2000 , the upper sampling location (mile 5.7) produced the highest WSCT densities with a CPUE for WSCT (fish> Catch $/ 100$ feet 4 ") of 4.1 and 1.0 for YOY (Figure 37).

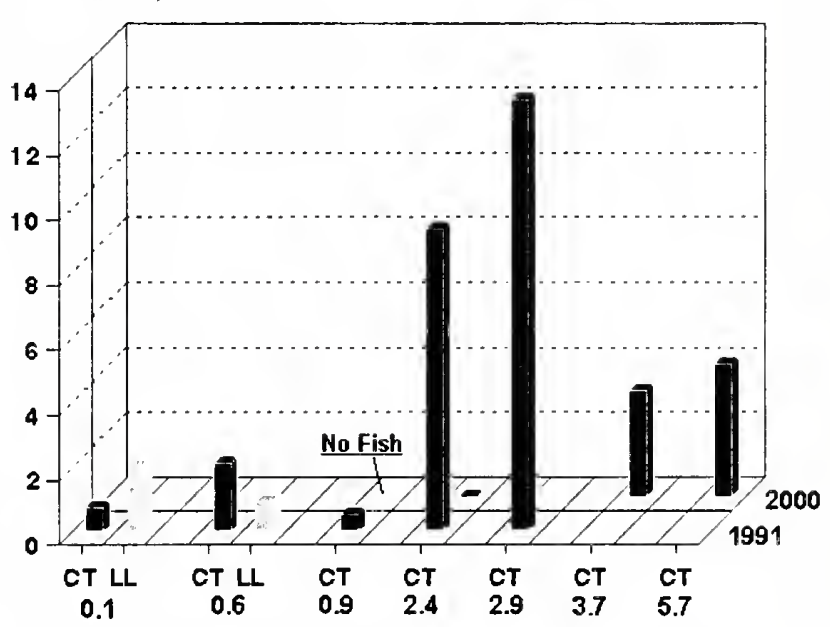

Figure 37. CPUE for fish $>4.0$ " at 7 sites on Wasson Creek 1991 \& 2000. 
At mile 3.7, sampling produced a CPUE for WSCT (fish $>4.0$ ") of 3.3 and 6.8 for YOY. Compared to 1991, the two duplicate samples (mile 0.9 and 2.4) undertaken in 2000 recorded much lower WSCT densities. At mile 2.4, we found no WSCT >4.0", compared to 9.3 in 1991; we recorded a CPUE of 2.6 for YOY in 2000 compared to 10.1 in 1991. In 2000, we also sampled the irrigation ditch at this site and found CPUE of 1.3 for YOY.

At mile 0.9 , we recorded no fish in 2000 compared to low density of 0.5 WSCT in 1991. Twenty-five genetic samples were taken from upper survey sites, the results of which are pending.

\section{Wilson Creek}

Wilson Creek is a 1 st order tributary that enters Lincoln Slough at mile 1.6 contributing a flow of $0.06 \mathrm{cfs}$ on 7-19-00. Lincoln Slough enters Nevada Creek at mile 17.6. Wilson Creek flows 5.8 miles through portion of Helena National Forest and private ranchlands. Stream gradients vary from $504^{\prime} / \mathrm{mile}$ in the headwaters to $60^{\prime} / \mathrm{mile}$ near the valley floor. In 2000, we established two fish population survey locations on Wilson Creek (mile 0.2 and 2.9) (Figure 38). We also surveyed an irrigation ditch at mile 2.2. Stream temperature monitoring (mile 0.4) recorded a maximum summer temperature of $71.4^{\circ} \mathrm{F}$ during August (Appendix I).

\section{Elevation (ft.) $\times 1000$}

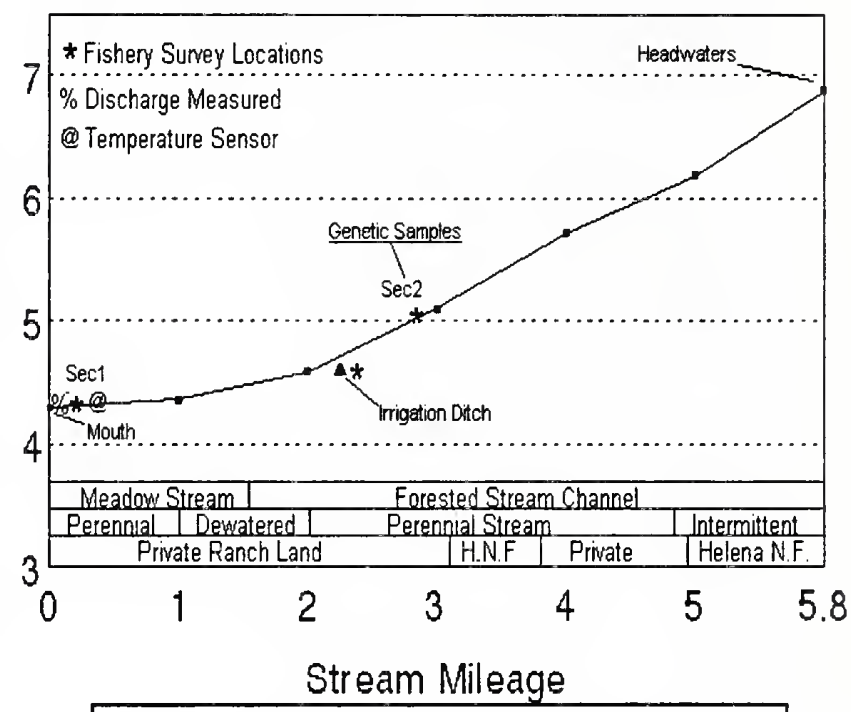

Figure 38. Longitudinal profile for Wilson Creek.

At the upper sampling location Catch/100 feet (mile 2.9) we found a healthy riparian area, 0.7 with a dense overstory of Douglas 0.6 understory above an alder, mountain maple, meadow rue, snowberry, and sumac understory. Within the bankfull width, ${ }^{0}$ mosses are the dominant species. The ${ }^{0.3}$ channel is a high gradient channel witho.2 cascading step pools containing small 0.1 amounts of instream wood. Dominant substrate type of this section is boulder, cobble and gravel. Livestock impacts were minimal.

The riparian area at the lower survey location (mile 0.2 ) has a healthy

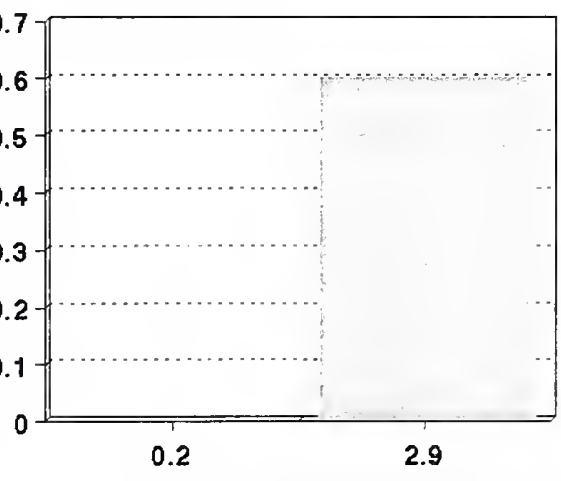

Location (stream mile)

Figure 39. CPUE for fish $>4.0$ " at 2 sites on Wilson Creek 2000. 
riparian area consisting of cottonwood, willow, alder and dogwood along with timothy and bulrush. However, the stream channel lacks sufficient instream wood to serve as fish habitat. The substrate at mile 0.2 is mainly gravel with lesser amounts of cobble.

Problems observed that affect the fish populations include dewatering (miles 1.0 2.2) and an unscreened irrigation ditch (mile 2.2.).

\section{Fish Populations}

WSCT was the only species found in Wilson Creek during the 2000 survey; the population is restricted to the headwaters in very low densities (Figure 39).

At the upper survey site (mile 2.9), sampling produced a WSCT CPUE (fish $>$ 4") of 0.7 and 11.9 for YOY. Sampling the irrigation ditch (mile 2.2) found a CPUE (fish $>4.0$ ") of 0.8 . We found no fish at mile 0.2 . Amphibians observed were western toads at mile 0.2 .

\section{Chimney Creek (tributary to Lincoln Slough)}

Chimney Creek is a small $1^{\text {st }}$ order stream. It upper reaches begin in the Helena National Forest and flows southwest 5.0 miles through private ranch land to its confluence with Lincoln Slough at mile 4.4. Chimney Creek is intermittent at its upper reaches and disjunct from the Lincoln Slough near the mouth due to the Highway 141 and other channel alterations. Stream gradients range from $440^{\prime} /$ mile in the headwaters to $180^{\prime} /$ mile near the mouth (Figure 40 ).

In 2000 , we established two sampling locations on Chimney Creek (mile 2.2 and 4.2). The upper survey site (mile 4.2) located on

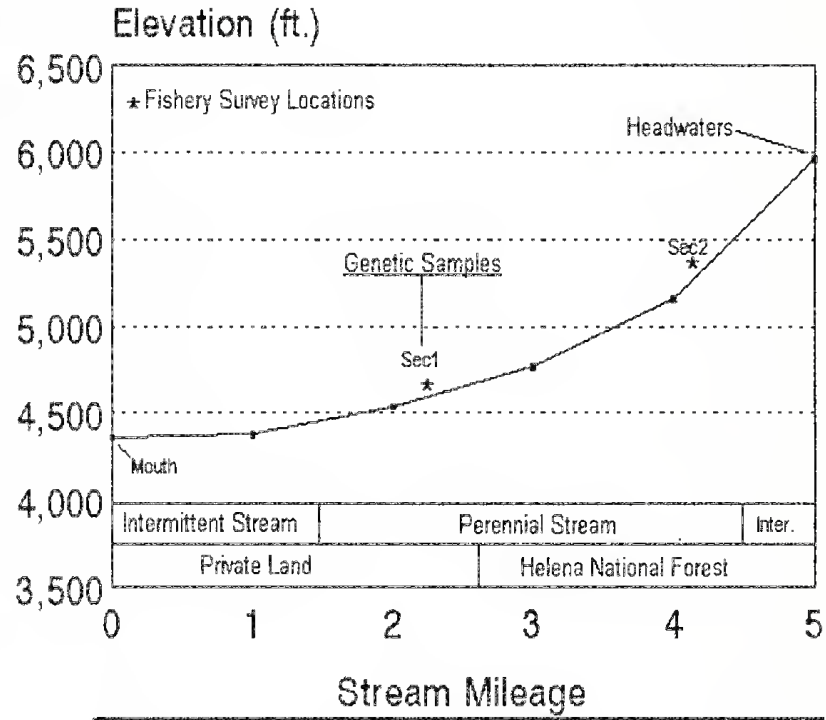

Figure 40. Longitudinal profile for Chimney Creek (trib. to Nevada Creek).

Helena National Forest found a small channel with a gravel/boulder substrate. The riparian habitat consisted of a full over-story of Douglas fir with a sparse under-story of white spruce, alder, mountain maple, mixed with snowberry, gooseberry, and meadow rue underlined with clover and cutgrass. Banks are stable with only natural erosion. We observed no problems at this site.

The downstream survey site (mile 2.2) found a healthy riparian area with a quaking aspen overstory above a dense mixed under-story of juniper, alder, thistle, cutgrass, and multiflora rose. Fish habitat varies between small pools containing high amounts of woody debris and runs with undercut banks.

Downstream of the lower fish population survey site (mile 2.2) and upstream of Highway 141, Chimney Creek provides irrigation. In the area of Highway 141, Chimney Creek channel alterations, culverts and downstream irrigation ditches all form barriers to fish passage. 
Fish Populations

Chimney Creek supports a small disjunct population of WSCT. No other species were found in Chimney Creek. In 2000, we established two fish populations survey stations (miles 2.2.and 4.2); only the lower station recorded the presence of fish. Our sampling produced a CPUE (fish>4.0") of 2.0 and 4.8 for YOY (Figure 41). We collected 17 WSCT genetic samples, the results of which are pending.

\section{Chicken Creek}

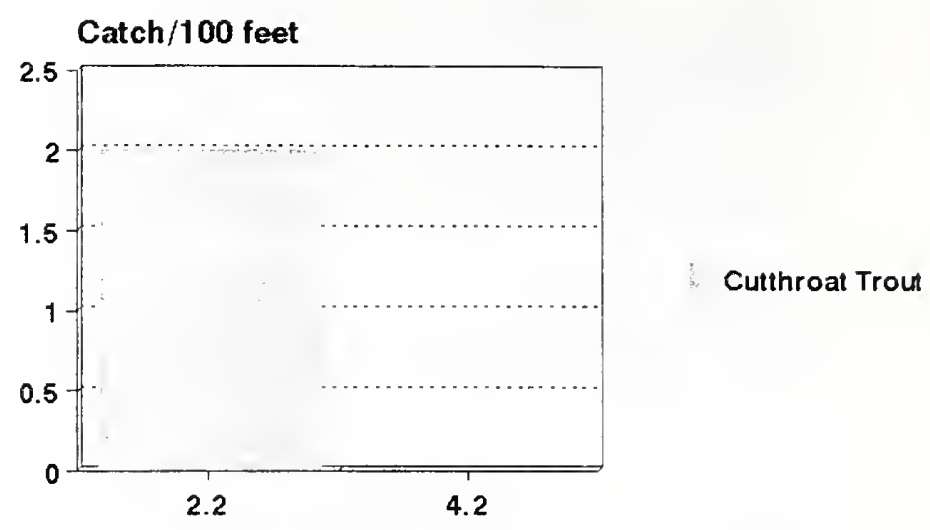

Location (stream mile)

Figure 41. CPUE for fish $>4.0$ " at 2 sites on Chimney Creek tributary to Lincoln Slough 2000.

At stream mile 27.8, Chicken Creek enters Nevada Creek 0.5 miles downstream of the Nevada Creek reservoir. A small $1^{\text {st }}$ order tributary stream, it drains the southern slope of Ogden Mountain with headwaters on the Helena National Forest. Chicken Creek flows southwest through Plum Creek Timber Co. land and private ranchland supplying a base flow of $1.7 \mathrm{cfs}$ to Nevada Creek on July 17, 2000. In 2000, we established two

Elevation (ft.) $\times 1000$

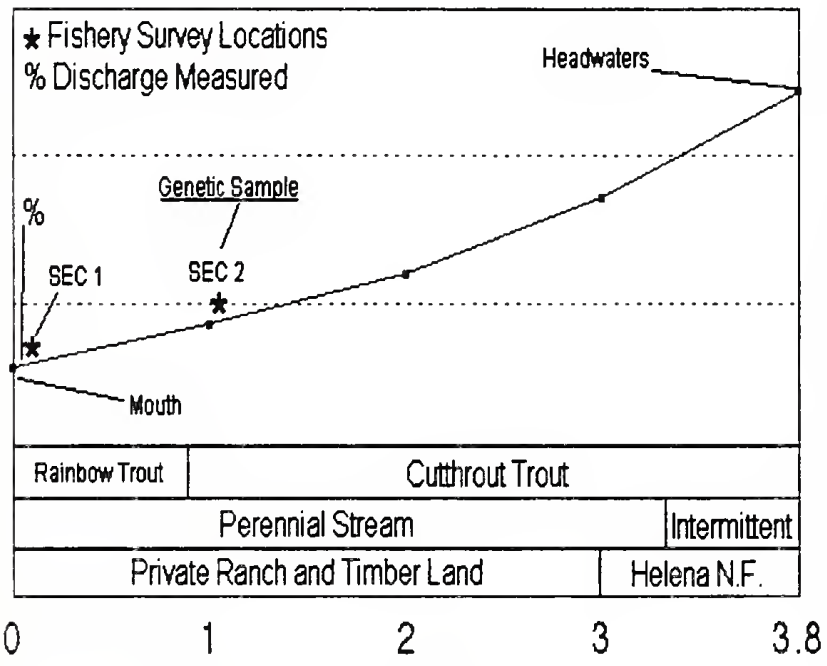

Stream Mileage

Figure 42. Longitudinal profile for Chicken Creek survey sites on Chicken Creek (miles 0.1 and 1.2). Limited access prevented fish population sampling in the upper watershed (Figure 42).

At the upper survey site (mile 1.2), the riparian habitat was in very poor condition. The stream banks were highly degraded from cattle use, causing the stream channel to become overwidened and shallow. Cattle wallowing areas supply high levels of sediment to the stream. Overgrazing of the under vegetation has left only a few plants such as, alder, hawthorn, rocky mountain maple, snowberry, and multiflora rose covered by an over-story of Douglas fir and cottonwood. Fish habitat is scarce, with only a few small pieces of alder debris creating any type of habitat.

At the lower sampling site (mile 0.1 ), we found a stable channel with a riparian habitat of timothy mixed with ricecutgrass, golden rod, bulrush, thistle, horsetail, and knapweed. No over-story exists. Overhanging vegetation and undercut banks serve as habitat for fish. Because of its close 
proximity to Cottonwood Meadows road, a light to moderate level of road sediment is present in the gravel/cobble substrate.

Fish Populations

Catch $/ 100$ feet

Chicken Creek supports very low densities of WSCT and rainbow trout, with WSCT dominating headwaters and ${ }^{0.0}$ rainbow trout limited to the lower stream0.6 reaches (Figure 43). The presents of rainbow trout may be related to rainbow ${ }^{0.4}$ stocking in Nevada Reservoir. Sculpins 0.2 are common at the lower site on Chicken Creek. We collected eight WSCT genetic samples from the upper site, the results of which are pending.

\section{Yourname Creek}

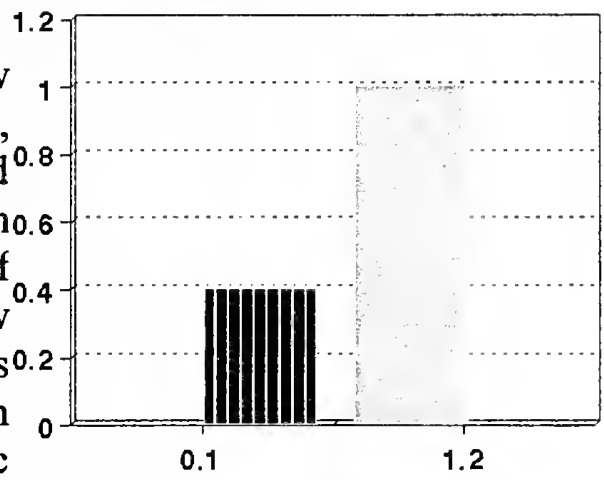

Location (stream mile)

Figure 43. CPUE for fish $>4.0$ " at 2 sites on Chicken Creek 2000.

Yourname Creek is a $2^{\text {nd }}$ order tributary stream to the middle reaches of the Blackfoot River. Yourname Creek begins on BLM land near Elevation Mountain in the Garnet Mountain Range and flows northeast through private ranchland to its confluence with the Blackfoot River (mile 65.3), located 2.5 miles downstream of the Nevada Creek confluence. Stream gradient varies from $570^{\prime} / \mathrm{mile}$ in the headwaters to $60^{\prime} /$ mile near the mouth. In August 2000, we establish three fish population survey sites (miles 1.1, 2.2, and 4.6); we also re-surveyed a 1992 site at mile 1.8. In addition, we sampled the Company ditch, which diverts water at mile 2.2 (Figure 44).

All survey sites contain a riparian under-story of alder, willow, red osier dogwood, wild rose, and snowberry. Woody debris recruitment is moderate at the three upper sites, supplying cover and creating scour pools for fish. Overhanging vegetation and undercut banks provide fish habitat at the lower site. The majority of the Yourname Creek drainage is subject to livestock grazing. Cattle grazing impacts are evident at all four sites. Impacts include bank erosion, shallow and over-widen areas of the stream channel, and Elevation (ft.) $\times 1000$

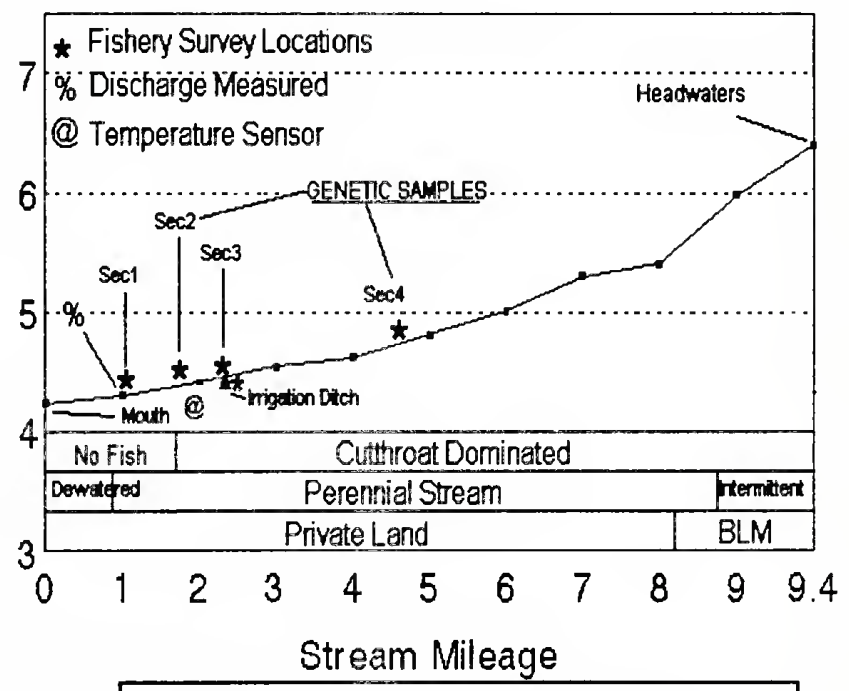
heavy grazing on all desirable under-story vegetation. 
The lower 0.7 miles of Yourname Creek is dewatering from irrigation withdraw, so the measurement of flow discharge occurred at stream mile 1.2 , recording $1.1 \mathrm{cfs}$ on 88-00. Flow was not measured in Yourname Creek above the Company ditch diversion.

Temperature monitoring at Yourname Creek (mile 1.8) recorded a monthly maximum of $68.3^{\circ} \mathrm{F}$ for August 2000. This is 9.1 degrees cooler than Nevada Creek (Appendix I).

Fish Populations

Fish population surveys for Yourname Creek found a native assemblage of WSCT and sculpins. In 8 2000, Yourname Creek supported some of the highest WSCT densities recorded in the Garnet Mountains. However, densities decline sharply in the 2 downstream direction below mile 4.6 (Figure 45)

Below the upstream sample (mile 4.6) WSCT (fish $>4.0$ ") showed declining densities with a CPUE of 10.0, compared to a CPUE of 6.4 at mile 2.2 .

\section{Catch $/ 100$ feet}

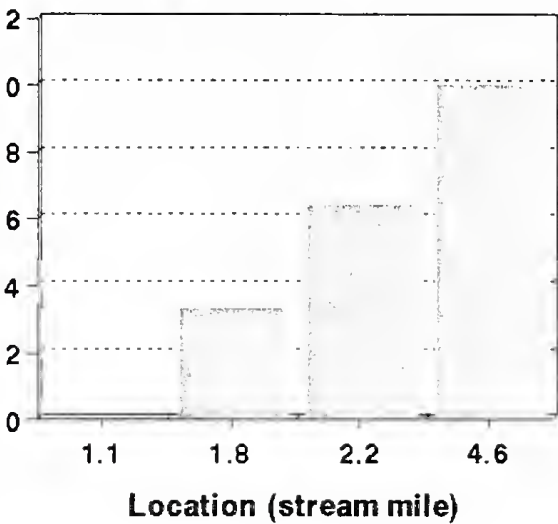

Figure 45. CPUE for fish $>4.0$ " at 4 sites on Yourname Creek 2000.

High densities of WSCT YOY at mile 2.2 indicate proximity to a primary spawning site (Appendix A).

A comparison of WSCT densities at mile 1.8, recorded a large decline (fish $>4.0$ ") in 2000 (CPUE =3.3) compared to 1992 (CPUE= 10.7). We also recorded a large decline for WSCT YOY in 2000 (CPUE=0.6) compared to in 1992 (CPUE=15.3).

Sampling the Company ditch, ( 0.4 mile downstream of the diversion), produced a WSCT (fish >4.0") CPUE of 1.0. We Elevation (ft.) $\times 1000$ collected 25 WSCT genetic samples; 7 results are pending.

\section{Wales Creek}

Wales Creek is a $2^{\text {nd }}$ order tributary to the Blackfoot River entering at river mile 60.2. Wales Creek drains BLM land in the mid-to-upper reaches before entering private ranch land near mile 4.0. Wales Creek enters Wales Creek Reservoir at mile 2.4. Stream $_{3}$ gradients range from an average of 302 ' $/$ mile above the reservoir to a mean of 190 '/mile below the reservoir. In 2000 , we re-sampled two fish population surveys established in 1989 (miles 0.1 and 1.9) (Figure 46). We also established

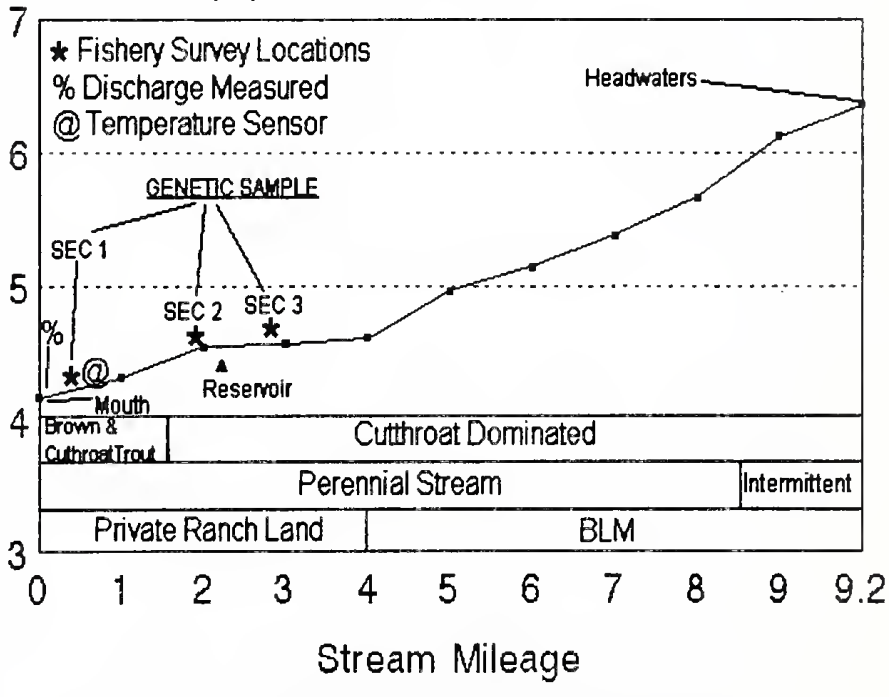

Figure 46. Longitudinal profile for Wales Creek. 
a new survey section above the reservoir (mile 2.6). On 8-8-00, we measured stream discharge at the mouth at $0.6 \mathrm{cfs}$. A temperature sensor at mile 0.3 , recorded a maximum August temperature of $71.1^{\circ} \mathrm{F}$, approximately $5^{\circ} \mathrm{F}$ lower than the maximum temperature recorded on the Blackfoot River 0.2 miles below the Wales Creek junction.

Above Wales Creek reservoir at the upper sampling site (mile 2.7), the riparian area was rated as healthy with an overstory of white spruce, Douglas fir, lodgepole pine, and ponderosa pine, above an alder shrub layer. In addition to a healthy riparian area and stable stream banks, Wales Creek contained moderate amounts of instream wood at the sampling site. However, upstream of the sampling location, portions of stream (mile 3.3 and 4.4) show heavy stream degradation from excessive livestock access, causing overwidened channels, erosion and elevated levels of instream sediment.

Below the reservoir at the middle sampling location (mile 1.9), the riparian area appeared healthy; however, the stream dewatering occurs due to low amount of water volume released from the Wales Creek Reservoir. The dense riparian vegetation of Douglas fir, ponderosa pine, alder, dogwood, gooseberry, raspberry, and horsetail, shades most of this section of the stream. The stream maintains adequate instream wood; however, most of the fish habitat consists of bedrock and large boulder substrate.

The riparian vegetation of the lower survey location (mile 0.1 ) includes ponderosa pine above an under-story community of alder, timothy, bulrush and sedge. The channel has recruited some instream wood. Slumping stream banks from excessive cattle use are creating many over-widened areas in the channel.

\section{Fish Populations}

Above the reservoir, we found a native fish assemblage of WSCT and sculpins. Sampling of WSCT produced a CPUE of 6.7 for fish $>4.0$ " and 13.0 for YOY.

Below the reservoir, both fish population survey sites recorded large declines in WSCT compared to upstream densities above the reservoir. Compared to 1989, we also recorded declining WSCT densities at both lower sample locations (Figure 47).

At mile 1.9, we sampled a WSCT (fish >4.0") CPUE of 2.9 in 2000 compared to 6.0 in 1989. We found no WSCT YOY in 2000, compared to a CPUE of 10.7 in 1989.

Near the mouth of Wales Creek (mile 0.1),

\section{Catch/100 feet}

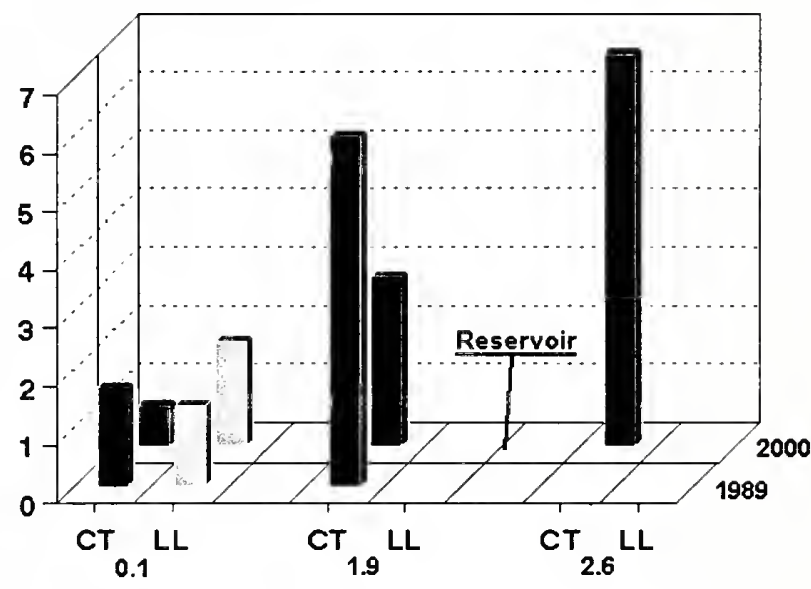

Figure 47. CPUE for fish $>4$ " at 3 sites on Wales Creek 1989 \& 2000.

we sampled WSCT, brown trout, mountain whitefish, sculpins and longnose dace. WSCT (fish >4") numbers again decreased from a CPUE of 1.7 in 1989 to 0.8 fish in 2000. CPUE for YOY cutthroat remained at 0.0 both sampling years. Brown trout (fish $>4$ ") numbers increased slightly in this section, from a CPUE of 1.5 in 1989 to 1.8 in 2000. Brown trout YOY also increased from 3.3 to 8.3. We collected 25 WSCT genetic samples ( 8 below and 17 above reservoir), the results of which are pending. 


\section{PART III: FISH POPULATION AND OTHER ASSESSMENTS FOR RESTORATION STREAMS}

Part III summarizes 2000 tributary restoration projects and fish population monitoring on project streams or streams considered for restoration (Figure 48). For most of these streams, more detailed project and fisheries information can be found in four previous reports (Peters 1990, Pierce, Peters and Swanberg 1997, Pierce and Schmetterling 1999, Pierce and Podner 2000). In Results Part III, both CPUE and density estimates are used. The $95 \%$ confidence intervals for density estimates are found in Appendix C.

\section{Bear Creek}

Restoration Objectives: restore habitat degraded by

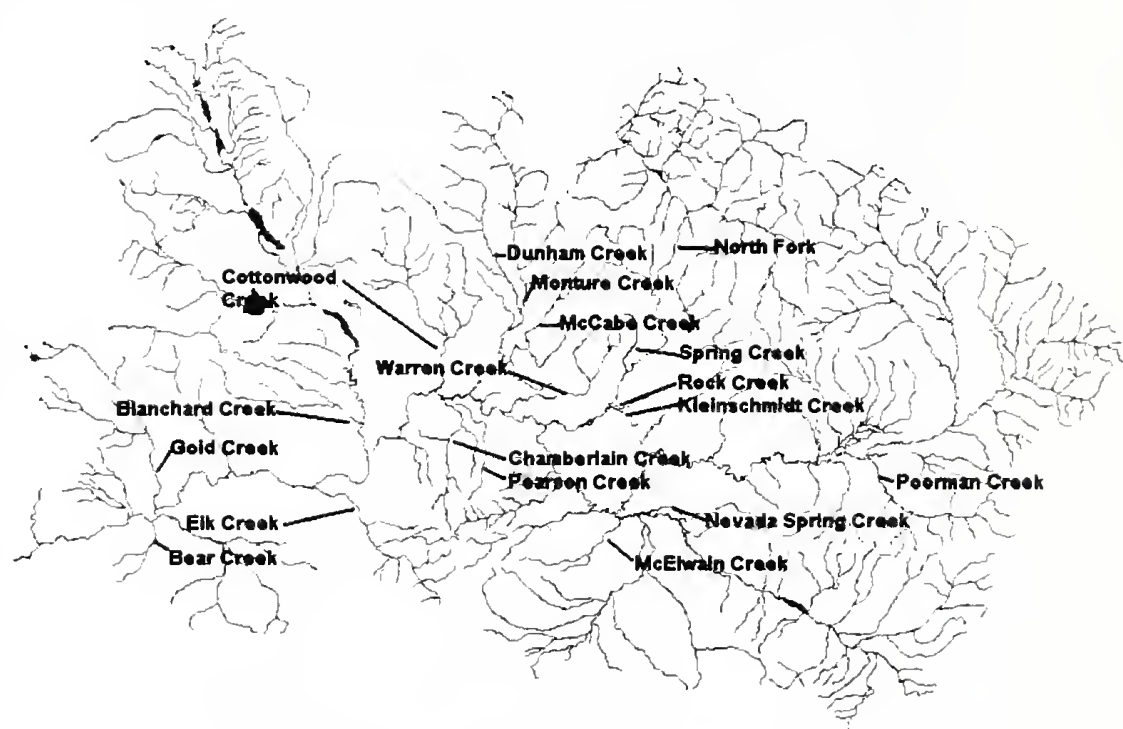

Figure 48. Current tributary restoration streams or streams being considered for restoration.

historical activities in the channel, restore fish passage and thermal refugia, improve recruitment of trout to the Blackfoot River.

\section{Project Summary}

Bear Creek, a small $2^{\text {nd }}$ order tributary of the lower Blackfoot River, flows six miles north to its mouth where it enters the Blackfoot River at river mile 12.2 with a base flow of 3-5 cfs. Bear Creek is one of the colder streams entering the lower Blackfoot River (Pierce and Podner 2000). Bear Creek has a long history of intensive riparian management activities, some of which have led to adverse habitat changes and other impacts to salmonids. Past riparian management activities resulted in undersized culverts, road drainage problems, irrigation impacts, channelization of the stream, riparian grazing and streamside timber harvest activities (Pierce et al. 1997, Pierce and Schmetterling 1999). These activities affect salmonids through the loss of migration corridors, dewatering and simplification of fish habitat.

Restoration of Bear Creek began in 1995 and continued through 2000. Projects included: 1) upgrading culverts and addressing road drainage problems; 2) improving water control structures at irrigation diversions; 3 ) reconstructing $2,000^{\circ}$ of channel and enhancing habitat complexity on an additional 2,000' stream; 4) shrub plantings and the development of riparian grazing systems for one mile of stream and includes offstream water. Activities for 2000 included shrub plantings and placement of additional large instream woody debris for 3000' of channel. 


\section{Fish Populations}

Bear Creek supports populations of rainbow trout, brown trout and brook trout. Prior to restoration, bull trout were absent from the drainage although they were present historically (FWP files). WSCT densities are very low:

In 1998 prior to channel reconstruction, two fish population survey sections were established in Bear Creek: one upstream section (mile 1.5) not affected by projects; and a downstream section (mile 1.1) in the reconstructed reach. In 1999, we established an adjacent downstream survey section (mile 1.1) in the newly constructed channel. In the project area (mile 1.1), total densities (fish >4.0") decreased by approximately $20 \%$ compared to 1999 (Figure 49), although YOY densities appear to have increased compared to 1998 (pre-project) densities (Appendix A). In 2000, we found one juvenile bull trout immediately upstream

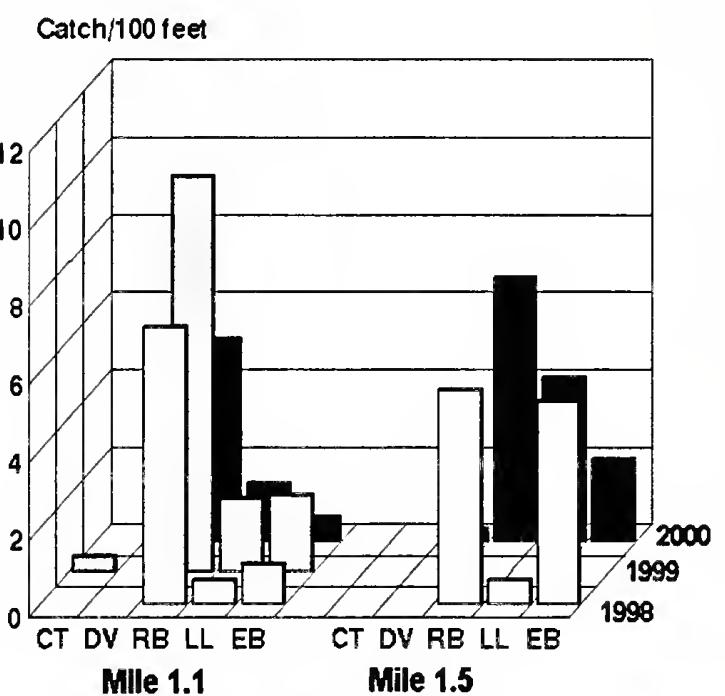

Figure 49. CPUE (fish>4.0") for Bear Creek at two locations, 1998-2000. of the project area-the first recorded in recent years.

\section{Blanchard Creek}

Restoration objectives: improve access, spawning and rearing conditions for trout and improve recruitment of trout to the Blackfoot River.

\section{Project Summary}

Blanchard Creek has a long history of intensive land management activities, some of which have resulted in adverse riparian impacts and loss of fish habitat. These include changes to the hydrograph $(12 \%$ above natural) related to extensive timber harvest (DNRC unpublished data), side casting of road grade material to the channel by county road maintenance activities, excessive riparian livestock access and historical irrigation practices. Two projects were implemented on Blanchard Creek to improve riparian health and fish populations: 1) riparian livestock management changes on State Land; and 2) irrigation upgrades near the mouth.

Blanchard Creek was historically dewatered in its lower one mile from irrigation, resulting in large fish population declines (Pierce et al. 1997). The irrigator began increasing flows in 1991. We implemented a water lease in 1993 in order to maintain a 3-cfs minimum instream flow during the irrigation season. 
Fish Populations

Blanchard Creek is a spawning tributary for rainbow trout that inhabit the Clearwater and Blackfoot Rivers. Lower Blanchard Creek now supports higher rainbow trout densities than historically due to the water leasing effort and related upgrades to irrigation diversions. In 1990, we estimated rainbow trout (fish <4.0") densities at $14.4 \pm 0.7$ trout $/ 100^{\prime}$ and larger rainbow trout (fish $>4.0^{\prime \prime}$ ) at $5.6 \pm 2.2$ in the dewatered reach. In 2000, rainbow trout (fish <4.0") densities we estimated at $48.5 \pm 6.9 \mathrm{fish} / 100^{\prime}$ and $7.5 \pm 1.9$ fish $/ 100^{\prime}$ for rainbow trout $>4.0$ ". We recorded moderate density declines in both size classes compared to 1999 (Appendix A, B). Rainbow trout (fish $>4.0$ ") densities also began

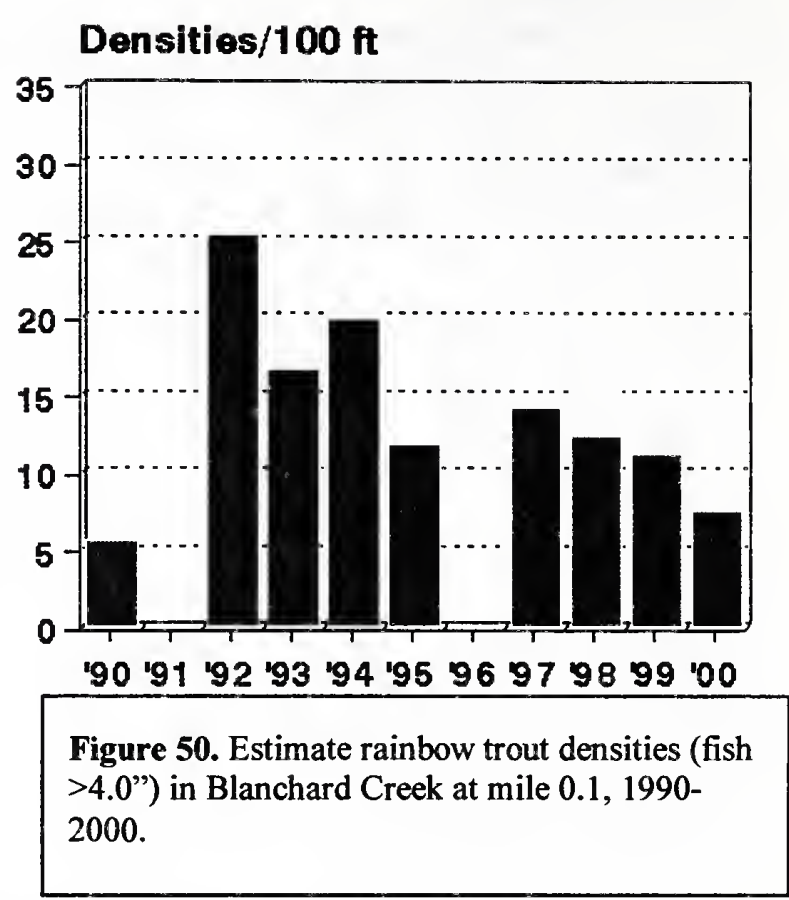

a declining trend beginning in 1992 (Figure 50). This trend probably relates to habitat changes (loss of instream wood) in the sampling section. YOY densities remain high in the sampling section.

\section{Chamberlain Creek}

Restoration objectives: improve access spawning and rearing conditions for westslope WSCT; improve recruitment of WSCT to the river; provide thermal refuge and rearing opportunities for fluvial bull trout.

\section{Project Summary}

The upper reaches of Chamberlain creek support excellent densities of WSCT; however, sections of lower Chamberlain Creek were severely altered, leading to historic declines in WSCT densities downstream of the West Fork (mile 4.0) (Peters 1990). Adverse changes to stream habitat included channelization, loss of instream wood, dewatering, poor riparian livestock management, road encroachment and excessive sediment from road drainage. Other problems included fish losses to irrigation ditches and poor fish passage.

Since 1990, Chamberlain Creek has been the focus of a comprehensive fisheries restoration effort. Projects include road drainage repairs, riparian livestock management upgrades, fish habitat restoration, irrigation upgrades (consolidate ditches, water conservation, eliminate fish losses to ditches, install a fish ladder on a diversion) and improved stream flows through water leasing. Most projects were completed downstream of mile 1.9. We completed similar projects on lower Pearson Creek-the largest tributary to Chamberlain Creek. In 2000, the BLM initiated a small project that will place instream large woody debris in an area of channel alterations. 


\section{Fish Populations}

In 2000, Chamberlain Creek and Pearson Creek supported the highest WSCT densities of all sampled Garnet Mountain streams. Radio-telemetry studies indicate Chamberlain Creek supports a large migration of fluvial WSCT from the Blackfoot River. Fluvial spawning occurs throughout the mainstem and extends into Pearson Creek and the East Fork of Chamberlain Creek (Schmetterling 1998). Beginning in 1997, we found low numbers of bull trout using the stream in areas affected by restoration (Pierce and Schmetterling 1999). Chamberlain Creek was identified as "suspect" for whirling disease in 1997. Subsequent whirling disease samples show the disease has escalated to a 2.8 grade infection in 1999 (Pierce and Podner 2000).

In 2000 , we continued to fish population monitoring, plus supported special study efforts related to whirling disease and fish passage. Studies included: 1) monitoring fish population at four long-term monitoring stations; 2) establishing a new fish population monitoring station (mile 2.2) in the area of proposed habitat work; and 3) an evaluation of Denil fish ladders (See Results Part IV). We also supported graduate research designed to identify risk factors (riparian and aquatic) that influence whirling disease infection levels. In support of this research, we installed a time series of sentinel cages for whirling disease testing at several locations (Appendix J), and collected temperature data at four locations (Appendix I).

WSCT populations at the three long-term monitoring sites (mile $0.1,0.5$, 1.9) show continued stable to improving densities in areas influenced by restoration (downstream of mile 1.9) including near the mouth (Figure 51). However, we also recorded declining densities upstream of the restoration area (mile 3.8), and considerably lower WSCT densities in the area (mile 2.2) proposed for restoration activity (Appendix $\mathrm{A}$ and B). In 2000, WSCT YOY densities increased at long-term monitoring sites, compared to 1998 (Appendix A).

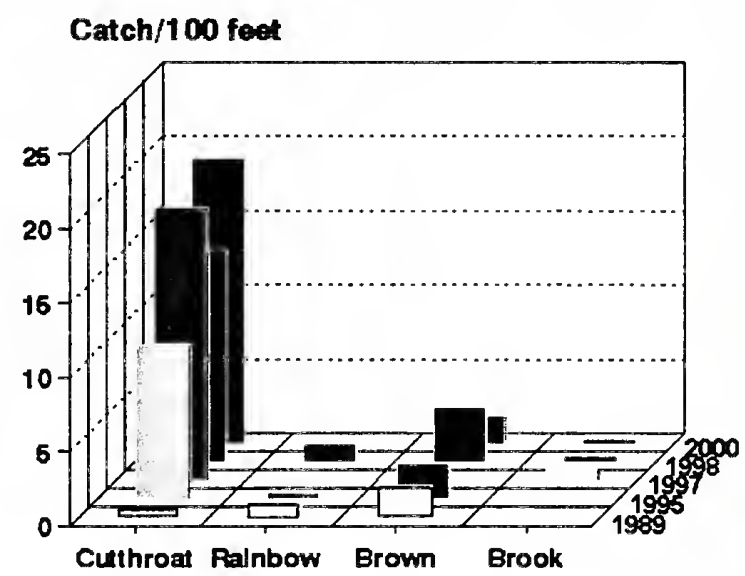

Figure 51. CPUE for salmonids (fish $>4.0$ ") for Chamberlain Creek at mile 0.1, 1989-2000.

\section{Cottonwood Creek}

Restoration objectives: improve degraded habitat, eliminate fish losses to irrigation ditches and restore migration corridors for native fish.

\section{Project Summary}

Cottonwood Creek, a large $3^{\text {rd }}$ order tributary to the middle Blackfoot River, begins near Cottonwood Lakes and flows 16 miles south from a glacial valley through prairie pothole country to its mouth at river mile 43. Cottonwood Creek supports populations of bull trout, WSCT, rainbow trout, brown trout and brook trout. Rainbow trout inhabit the lower mile of stream while brook trout and brown trout dominate middle stream reaches. WSCT and bull trout dominate the upper basin.

Impacts to fish and their habitats have occurred throughout the Cottonwood Creek 
drainage although many of the major problems were addressed in the last several years. Completed restoration measures include water conservation and water leasing, upgrading irrigation diversions with fish ladders and fish screens and implementation of riparian grazing systems along Cottonwood and Shanley Creeks. Problems still limiting fish populations include reduced riparian health and simplified habitat in the middle reaches of Cottonwood Creek, recent loss of spawning and rearing areas in Spring Creek, culvert barriers on the North Fork of Cottonwood Creek, and high whirling disease infection levels in the lower reaches of Cottonwood Creek (Pierce and Podner 2000).

\section{Fish Populations}

Following implementation of the water lease, WSCT densities have increased for both YOY (fish <4.0") and age 1+ (fish $>4.0^{\prime \prime}$ ) and older fish. The CPUE for YOY increased from 0.0 in 1997 to 9.2 in 2000. The CPUE for larger WSCT (fish >4.0") increased from 2.0 in 1997 to 7.2 in 2000. Densities of other species including bull trout remain low (Figure 52).

Whirling disease studies report a high-grade infection in lower Cottonwood Creek although infection levels and $T$. tubifex densities decline in the upstream

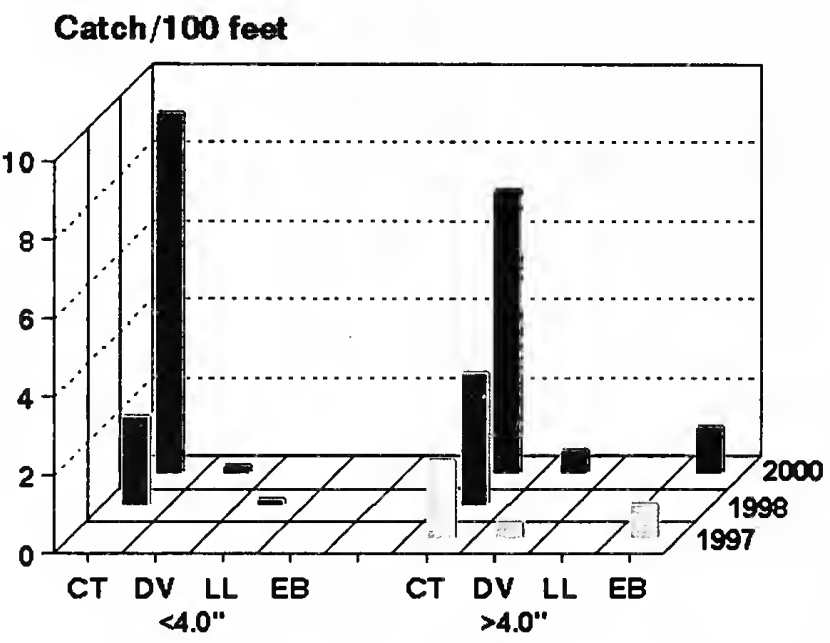

Figure 52. CPUE for salmonids sampled in Cottonwood Creek at Mile 12.0, 1997-2000.

direction (Smith 1998, Pierce and Schmetterling 1999).

\section{Elk Creek}

Restoration objectives: eliminated significant sources of sediment; improve management of livestock; improve reproduction, rearing and recruitment of all species to the Blackfoot River

\section{Project Summary}

Elk Creek, an impaired tributary to the lower Blackfoot River, originates in the Garnet Mountains and enters the Blackfoot River at river mile 28.0. Elk Creek is the only direct Blackfoot River tributary with increased spawning, rearing and recruitment potential to a 21-mile section of the Blackfoot River between Belmont Creek (mile 21.9) and Cottonwood Creek (mile 42.9). Elk Creek has a long history of adverse land management activities that affect fish populations. These include placer mining, channelization, road construction and maintenance activities, road drainage problems and concentrated riparian livestock grazing, all of which contributed to elevated levels of instream sediment and other impacts to fish habitat.

Lower Elk Creek also suffers temperature problems. Past studies have shown a $\sim 6.0^{\circ} \mathrm{F}$ temperature increase in the lower three miles of stream (Pierce and Schmetterling 1999). In 1999, Elk Creek had higher temperatures than 18 other streams (Pierce and 
Podner). In august 2000, Elk Creek recorded the highest stream temperatures of all monitored streams with maximum of $78.5^{\circ} \mathrm{F}$ (Appendix I). Reduced riparian health, loss of shrub overstory and wetland developments all seem to contribute to excessive warming.

In 1994, a major erosion control project was undertaken in a channelized section of lower Elk Creek (mile 1.3-2.9) in order to improve water quality in lower Elk Creek. This cooperative project included the reconstruction of $8,600^{\prime}$ of new channel as well as some livestock management changes (Pierce et al. 1997). Although this necessary project addressed a major water quality problem, monitoring of temperature and fish populations suggest that fish population recovery requires improvement of riparian heath. Riparian revegetation (woody species) and revised grazing management strategies should be considered if fish populations in lower Elk Creek are to recover.

\section{Fish Populations}

In 2000 , we re-sampled five fish population survey sections, four of which (mile 0.1, 1.1, 3.0 and 4.6) were established in 1991. These early surveys were established to evaluate

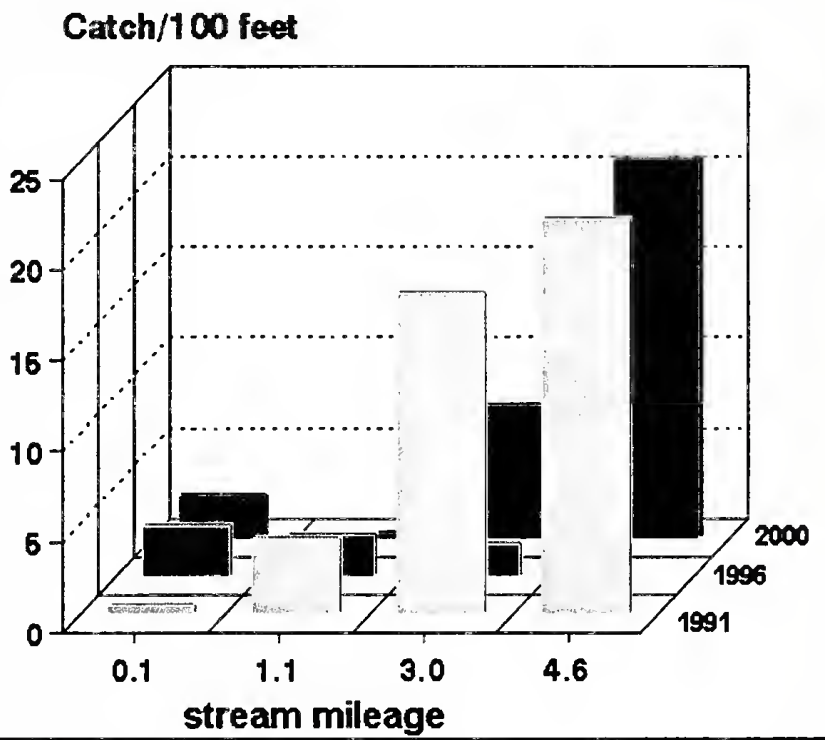

Figure 53. Total CPUE (all salmonids $>4.0$ ") for four sections of lower Elk Creek, 1991, 1996 and 2000. channel reconstruction and proposed land management changes on fish populations in lower Elk Creek (Pierce et al. 1997). We also re-sampled a population monitoring station (mile 2.3) established in 1995 in the newly constructed channel one year postproject. In 2000, we also established a new upstream population survey site (mile 6.2).

At the four long-term monitoring stations established in 1991, fish populations show no improvement with continued large declines in the downstream direction (Figure 53). For individual sampling locations, total trout densities (fish >4") appear to be: 1) at static low densities near the mouth (mile 0.1$) ; 2$ ) in

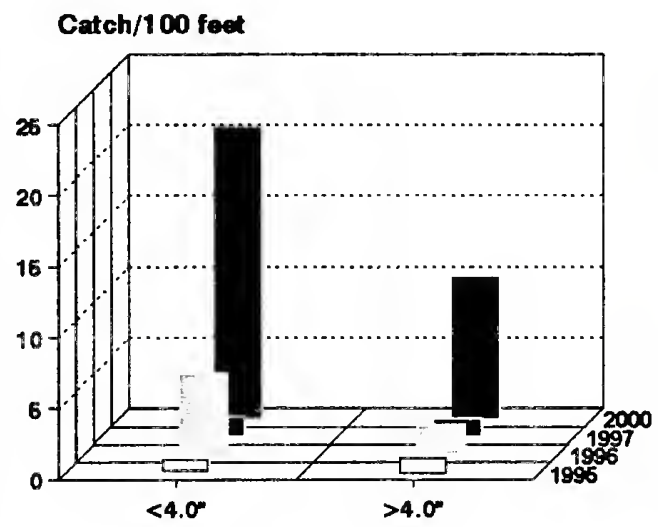

Figure 54. Total CPUE (fish $>4.0^{\prime \prime}$ ) for a reconstructed section (mile 2.3) of Elk Creek, 1995-2000.

decline upstream of Highway 200 (mile 1.1); and 3) at higher at both upper sampling sites, but comparable to previous densities (mile 3.0 and 4.6). WSCT densities also declined at the upper sampling location (mile 4.6) (Appendix A).

Fish population monitoring in the new channel (mile 2.3), recorded increasing 
rainbow trout densities with a CPUE (fish $>4.0$ ") of 1.0 in 1995 (one year post channel construction) increasing to 10.0 in 2000 . In 2000 , this section supported $35 \%$ more salmonids (fish $>4.0$ ") than the upstream section at mile 3.0. Likewise, YOY rainbow trout recorded a CPUE increasing from 0.8 in 1995 to 20.5 in 2000 (Figure 54). Elk Creek has tested negative for whirling disease.

\section{Gold Creek}

Restoration Objectives: restore pool habitat and morphological complexity, restore thermal refugia for Blackfoot River native fish.

\section{Project Summary}

Gold Creek is the largest tributary to the lower Blackfoot River, entering at river mile 13.5. The harvest of riparian conifers combined with the actual removal of large woody debris from the channel reduced habitat complexity in the lower three miles of Gold Creek. Prior to 1996, pools accounted for less than 1\% of the stream area in this section of stream. Low densities of age $1+$ fish, including native fish, resulted from the habitat simplification. In 1996, we installed 66 habitat structures made of native material (rock and wood) that resulted in 61 new pools in the 3-mile section.

\section{Fish Populations}

Gold Creeks is an important spawning tributary to the lower Blackfoot River for bull trout, WSCT, rainbow trout and brown trout. Resident populations of brook trout also inhabit the drainage.

In 1996 (prior to restoration), we established a fish population

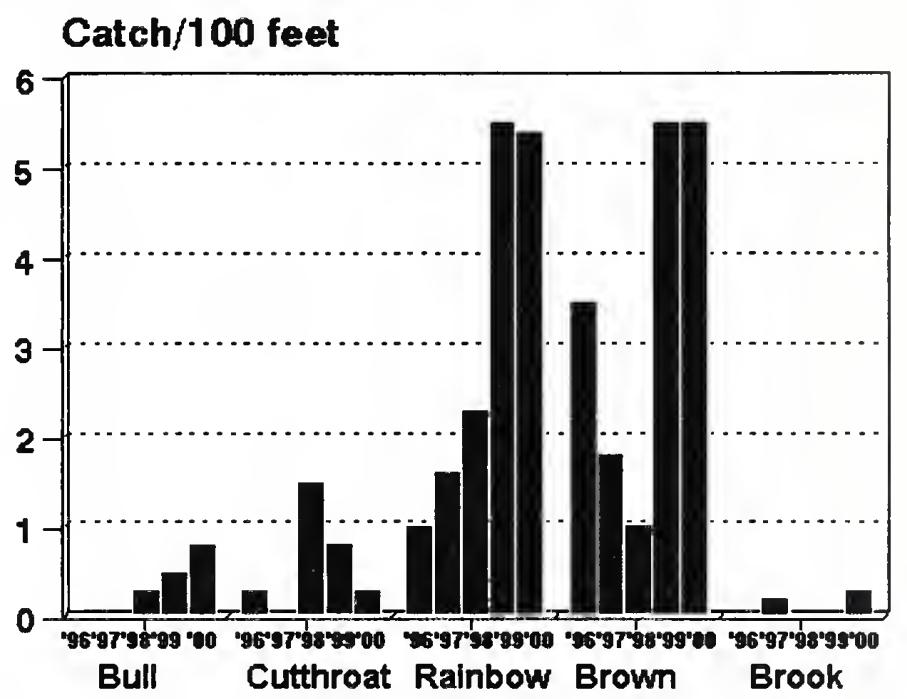

Figure 55. CPUE for Fish $>4.0$ inches at Gold Creek (mile 1.9), 1996-2000.

survey section in the treated area. Annual surveys show increasing densities for bull trout, rainbow trout and brown trout in the section in 2000, but a decline for WSCT compared to 1999 (Figure 55). Telemetry studies have shown the project area receives seasonal use by migratory Blackfoot River bull trout in the fall and fluvial WSCT use in the late spring (Pierce et al 1997, Schmetterling 2000).

In 2000, stream temperature monitoring near the mouth recorded maximum temperatures $6.5^{\circ} \mathrm{F}$ cooler than the Blackfoot River. (Appendix $\mathrm{H}$ ).

In 2000, sentinel cage studies identified Gold Creek as supporting a low-level whirling disease infection.

\section{Kleinschmidt Creek}

Restoration objectives: reduce whirling disease infection levels, restore stream channel morphology for all life stages of trout, increase recruitment of trout to the Blackfoot 
River, and restore thermal refugia and rearing areas for North Fork bull trout.

\section{Project Summary}

Kleinschmidt Creek, a spring-fed tributary of the North Fork of the Blackfoot River entering at mile 6.1, is degraded over most of its 1.3 -mile length due to channelization, over-widened channels and a history of intensive riparian grazing. To date, $3000^{\prime}$ of stream has been reconstructed and restoration is planned on an additional 5,000 ' of in 2001. Kleinschmidt Creek supports a high level of whirling disease infection (Pierce and Podner 2000). A proposed channel reconstruction and riparian restoration project will test the hypothesis that restoring health to a degraded spring creek can moderate whirling disease.

Catch/100 feet

Fish Populations

Kleinschmidt currently supports low numbers of brown trout and brook, along with very low densities of bull trout (Pierce and Podner 2000).

In 2000 , two types of prerestoration project data collection continued in Kleinschmidt creek: 1) fish population surveys at two locations, and 2) a whirling disease sentinel cage study (Appendix J).

In 1998 we established two population surveys sites (mile 0.5 and 0.8 ) in Kleinschmidt Creek. The lower survey site (mile 0.5 ) is located in a degraded, over-widened and untreated reach. The upper survey site (mile 0.8) is located in a channel section reconstructed to an E-type channel in 1997. At the mile 0.5-control section, the 2000 trout density estimates (fish $>4.0$ ") recorded no change from 1997 to 2000. At the 0.8-mile treatment section, densities of both brook trout and brown trout (fish $>4.0$ ") continued to increase (Figure 56). However, brown trout YOY are showing an opposite trend with increasing densities in the lower degraded (mile 0.5) section and decreases in the upper restored (mile 0.8) section (Appendix A and B).

\section{McCabe Creek}

Restoration objective: restore instream flows and habitat conditions for bull trout and WSCT.

\section{Project Summary}

McCabe creek is located in the Monture Creek bull trout recovery area. McCabe Creek a cold basin-fed tributary to lower Dick Creek entering at stream mile 3.8. The 
upper portion of the stream is a steep mountain stream before entering knob-and-kettle topography in the lower basin. McCabe Creek has among the coldest recorded summer time stream temperatures recorded of any tributary in the Blackfoot Watershed, with mean daily temperatures ranging between $43-48^{\circ} \mathrm{F}$ in 1998 (Pierce and Schmetterling 1999). In lower reaches, McCabe Creek enters a series of beaver-influence wetland bogs before entering Dick Creek.

McCabe Creek has a long history of adverse habitat changes related to channel alterations and agricultural activities. These include chronic dewatering, intensive riparian grazing, physical alterations to the channel and poorly designed road crossings.

In 1999-2000, a comprehensive restoration project was undertaken in McCabe Creek. The effort 1) consolidated four irrigation ditches into one pipeline and screened the intake; 2) helped convert from flood to sprinkler irrigation; 3) restored habitat conditions including the placement of instream wood and shrub plantings along $1 / 2$ mile of stream; 4) made necessary riparian livestock management changes; and 5) improved a county road crossing.

Two major fish population benefits of the project relate to increasing stream flows, and reducing WSCT losses to ditch system using a turbulent fountain fish screen at the ditch intake (Results Part IV). These irrigation improvements are expected to double instream flows from 4 to $8 \mathrm{cfs}$ during the irrigation season. This project will help augment downstream flows and help cool lower Dick Creek.

\section{Fish Populations}

McCabe creek is a WSCT dominated stream with low densities of brook trout in lower stream reaches. Due to cold temperatures, we suspect McCabe Creek historically supported bull trout. In 1999 , fish population surveys were established in two restoration project locations. We established the upper survey site (mile 3.2) upstream of an irrigation diversion prior to screening (turbulent fountain, Results Part IV). We established the lower survey site (mile 2.3) immediately downstream of the lower-most diversion in an area of low habitat complexity and reduced stream flows. In 1999 prior to project implementation, WSCT (fish > 4.0") declined from a CPUE of 7.0 at the upstream site to 2.1 at the

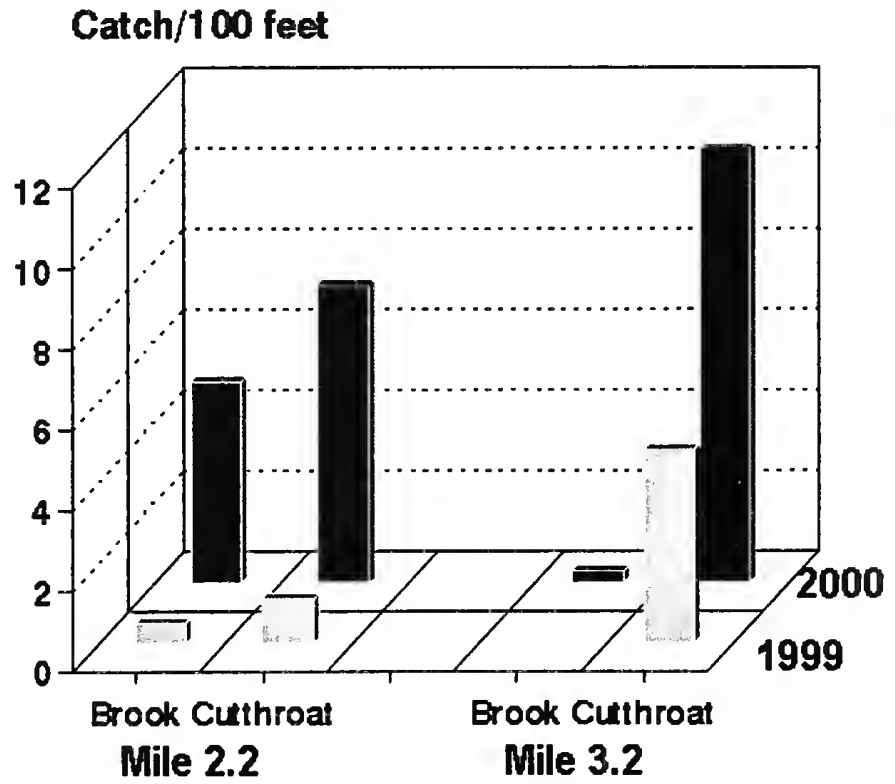

Figure 57. CPUE for WSCT and brook trout (fish.4.0") at two locations on McCabe Creek. 1999-2000. downstream location (Figure 57). In 2000, WSCT (fish >4.0") increased at both sections compared to 1999 (Appendix B). Upstream of the turbulent fountain (mile 3.2), WSCT densities (fish $>4.0^{\prime \prime}$ ) doubled from $7.0 \pm 1.6 \mathrm{fish} / 100^{\prime}$ in 1999 to $13.8 \pm 1.5 \mathrm{fish} / 100^{\prime}$ in 2000 . 


\section{Monture Creek}

Restoration objectives: restore habitat for spawning and rearing bull trout and WSCT, improve staging areas and thermal refugia for fluvial bull trout, improve recruitment of bull trout and WSCT to the Blackfoot River.

\section{Project Summary}

Monture Creek, a large tributary to the middle Blackfoot River, is a primary spawning and rearing tributary for fluvial bull trout and fluvial westslope WSCT. Reproduction for these species occurs primarily in the mid- to upper basin. Rainbow trout and brown trout inhabit the lower portions of the drainage. Brook trout are found throughout the drainage.

The lower to middle portion of the drainage has a long history of adverse impacts to native fish habitat related to past riparian timber harvest and grazing practices. Many of these problems have been corrected through a decade of cooperative restoration activities (Pierce et al. 1997, Pierce and Schmetterling 1999, Pierce and Podner 2000).

Fish Populations and other monitoring

Monitoring completed in 2000 included 1) bull trout redd counts, 2) juvenile fish population survey at five locations, and 3) a whirling disease sentinel cage study in

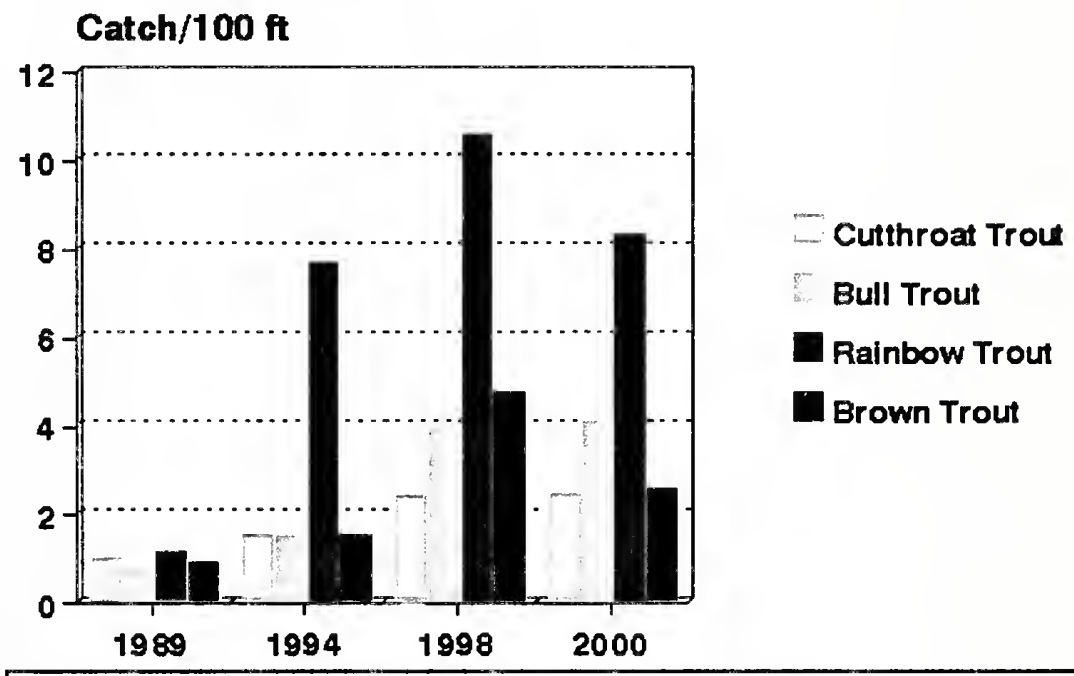

Figure 58. Combined CPUE ( 5 sections) for salmonids in Monture Creek, $1989,1994,1998$ and 2000.

lower Monture Creek near the mouth.

Bull trout redd counts continued an upward trend in 2000 with a total of 80 redds recorded in Monture Creek compared to 74 in 1999 (Figure 1). In 2000, juvenile fish counts continued at five long-term monitoring stations located between mile 0.4 and 12.9 (Appendix A). Combining all survey stations, sampling results from 1989 to 2000 show continued upward trends for all species, although densities for rainbow and brown trout declined in 2000 compared to 1998 (Figure 58).

\section{Nevada Spring Creek}

Restoration objectives: restore habitat suitable for a cold water trout; improve downstream water quality and reduce thermal stress in Nevada Creek and the Blackfoot River.

\section{Project Summary}


Nevada Spring Creek, located in the lower Nevada Creek valley, originates an artesian aquifer and flows 3.2 miles to its junction with Nevada Creek located at mile 6.2. In the past, stream discharge was measured at $10-11 \mathrm{cfs}$ below the spring source (Pierce and Peters 1990). Immediately below the spring source, Wasson Creek enters Nevada Spring Creek with 2-4 cfs during base-flow periods. Nevada Spring Creek also receives flow from small spring seeps in the mid-to lower reaches. Earlier temperature studies recorded a constant summer-time temperature of $44-45^{\circ} \mathrm{F}$ at the spring source (mile 3.2) (Pierce and Peters 1990). In 2000, we recorded maximum stream temperatures at $78^{\circ} \mathrm{F}$ near the mouth (mile 0.1). Maximum stream temperatures increased $14^{\circ} \mathrm{F}$ between mile 0.7 and mile 3.2 (Figure 59).

Nevada Spring Creek is a degraded spring creek and contributes warm water plus elevated levels of nitrate and phosphate to lower Nevada Creek (Pierce and Peters 1990, Pierce et al. 1997). However, Nevada Spring Creek through habitat restoration has potential to provide significant downstream cooling in lower Nevada Creek and possibly the Blackfoot River. From a water quality perspective, restoration of Nevada Spring Creek may be the most costeffective and beneficial project in the lower Nevada Creek watershed.

Limited past restoration efforts

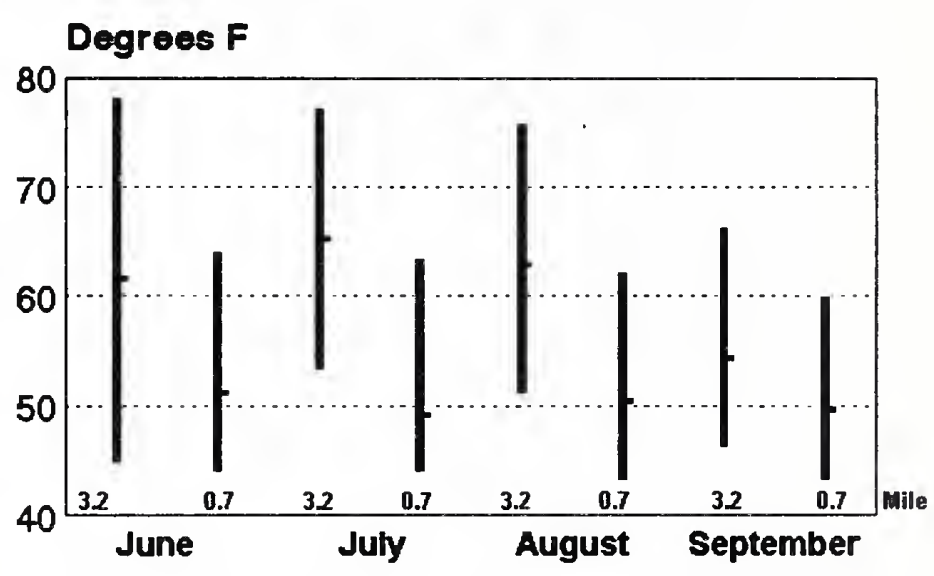

Figure 59. Max., Min. and mean stream temperatures of Nevada Spring Creek at mile 0.7 and 3.2, Summer 2000.

(fencing, shrub plantings and placement of instream wood) were completed on upper Nevada Spring Creek (mile 2.6-3.2) in 1990. A habitat restoration effort is now being developed for the middle reach of Nevada Spring Creek (mile 1.6-2.6). The project entails reconstruction of an over-widened and degraded channel along with necessary livestock management changes.

\section{Fish Populations}

In 2000, we sampled fish populations in Nevada Spring Creek at three locations (mile $0.8,2.8$ and 3.0). The two upper samples compare population densities of a degraded reach (mile 2.8) to a reach where livestock were excluded from immediate streambanks (mile 3.0) in 1990. These samples provide 1) a pre-treatment (mile 2.8) and control (mile 3.0) data set for the upcoming project, and 2) a comparison of fish populations related to two riparian management strategies.

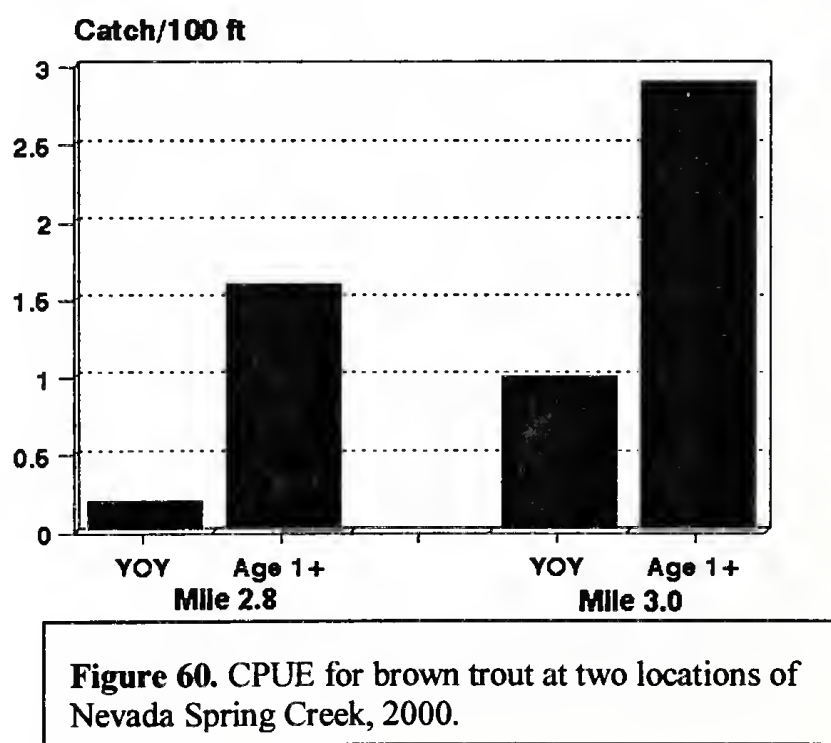


We also sampled fish in la degraded lower reach of Nevada Spring Creek at mile 0.8. The downstream sample (mile 0.8 ) found only non-game species tolerant of impaired stream conditions including redside shiner, longnose sucker and northern pikeminnow. By contrast, both upper samples (mile 2.8 and 3.0) found only salmonids, including low densities of brown trout and mountain whitefish, and very low densities of WSCT. The uppermost sample (mile 3.0), located in an area of restricted livestock access, recorded a CPUE for brown trout (fish $>4.0$ ") of 2.9 compared to 1.6 in the more degraded downstream reach (mile 2.8). Brown trout YOY numbers were also higher in the upstream location $(\mathrm{CPUE}=1.0)$ compared to the downstream location $(\mathrm{CPUE}=0.2)$ (Figure 60). Population estimates and additional catch statistics can be found in Appendix A and B.

\section{Pearson Creek}

Restoration objectives: restore the stream to its original channel, improve stream flows and access to historical spawning sites for fluvial WSCT.

\section{Project Summary}

Pearson Creek is a small $2^{\text {nd }}$ order Garnet Mountain tributary to the Chamberlain Creek with a base-flow of approximately one-cfs. Pearson Creek has a history of channel alterations, irrigation and riparian land management impacts in its lower 2 miles of channel. The Pearson Creek restoration effort includes conservation easements, water leasing, channel reconstruction, riparian habitat restoration and improved riparian grazing management (Pierce et al 1997). In 2000, continued restoration involved 1) placing instream woody debris, 2) riparian livestock management measures and 3) shrub plantings in WSCT spawning and rearing areas.

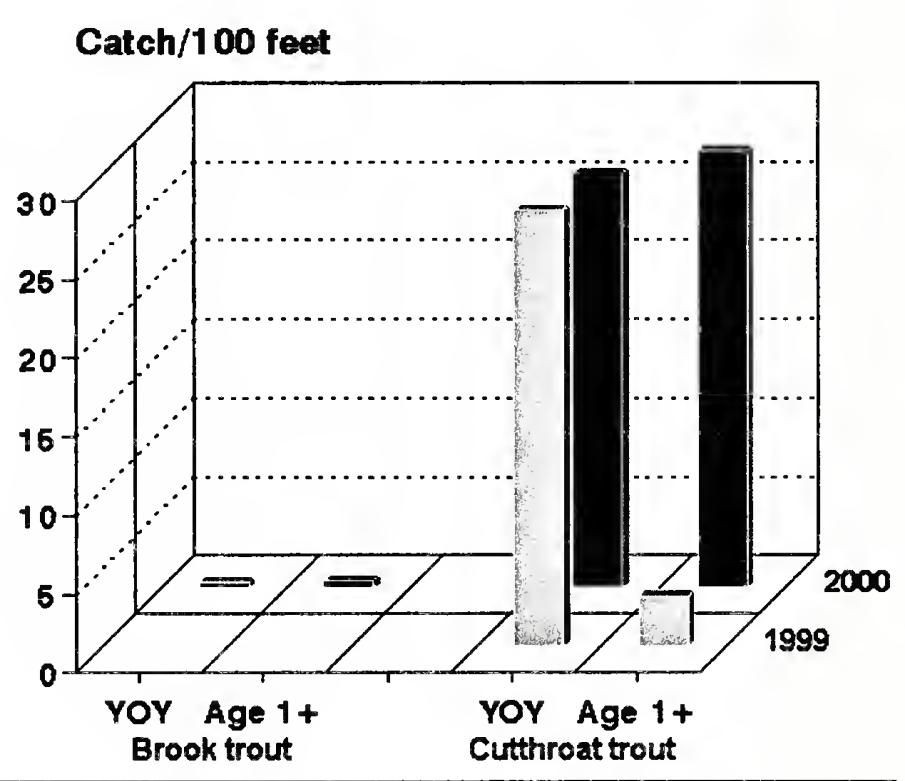

Figure 61. CPUE for brook trout and WSCT (Fish $>4.0$ ") at mile 1.1 , before and after a restoration project.

\section{Fish Populations}

Pearson Creek supports spawning migrations of fluvial WSCT-including increasing densities of juvenile WSCT, along with low densities of brook and brown trout in lower stream reaches. In August 2000, three months post-project, we resurveyed a fish population survey section established in 1999 prior to restoration (Pierce and Podner 2000). A comparison of the densities show no change in YOY densities but a significant increase in the age I+ WSCT following the project with densities increasing from $10.9 \pm 4.2$ in 1999 to $33.6 \pm 2.2$ in 2000. A comparison of CPUE for WSCT shows the response of larger WSCT (Figure 61). 


\section{Rock Creek}

Restoration Objectives: restore migration corridors for native fish and restore natural stream morphology to improve spawning and rearing conditions for all fish using the system.

\section{Project Summary}

Rock Creek, a basin-fed stream over most of its length, also receives significant groundwater inflows between mile 1.2 and 1.6. Rock Creek was degraded over most of its 8.2-mile length due a wide range of historical channel alterations and riparian management activities (Pierce 1990, Pierce et al. 1997). In 1999, we reconstructed $2,500^{\prime}$ of degraded and over-widened stream to Rosgen E4 geometry, bringing the total amount of restored stream to 5.5 miles. The restoration project included placing instream woody debris and shrub plantings throughout the project area. The project was in the transition reach between surface and groundwater inflows. In 2000, additional project developments for Rock Creek included channel design and fund-raising for the remaining 2.7 miles of degraded channel.

\section{Fish Populations}

Rock Creek supports spawning migrations of brown trout and rainbow trout in lower reaches, and provides WSCT and bull trout migration corridors to headwater areas. In 2000 , we continued population monitoring at a site (mile 1.7) established in 1998 one-year prior the 1999 channel reconstruction project (Pierce and Schmetterling 1999). We observed spawning brown trout and brook trout in the newly constructed channel in fall 1999 (Pierce and Podner 2000). The 2000 survey showed CPUE increases for brown trout and brook trout YOY, and age 1+ brown trout (Figure 62, Appendix B). Sentinel cage studies identified Rock Creek as supporting a low level of whirling

\section{Catch $/ 100 \mathrm{ft}$}

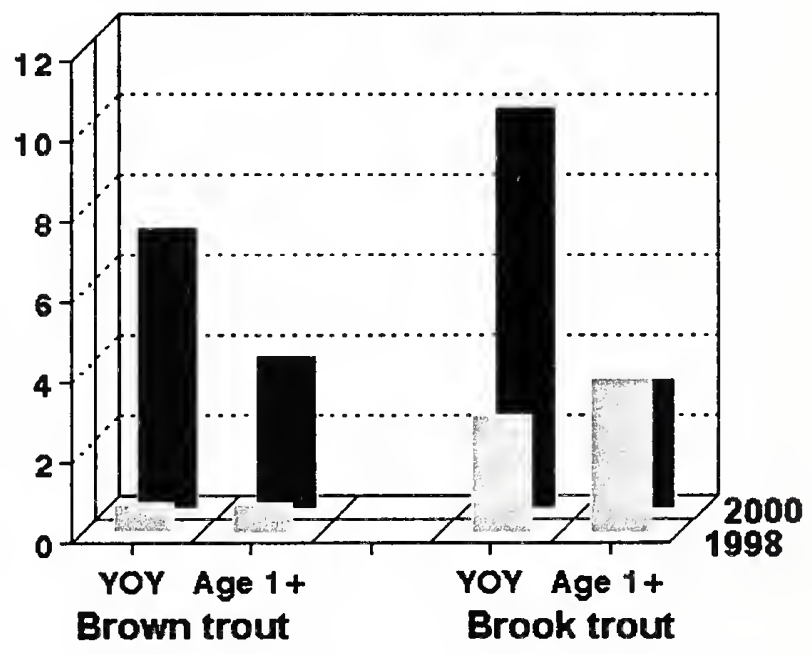

Figure 62. CPUE for brown trout and brook trout at mile 1.7 before (1998) and after (2000) a restoration project

\section{Spring Creek (trib. to North Fork)}

Restoration Objectives: restore migrations of juvenile bull trout, reduce losses of fish to irrigation ditches and maintain minimal instream flows.

\section{Project Summary}

Spring Creek, a small WSCT dominated tributary, originates on the north side of Ovando Mountain and flows 6 miles south where it enters the lower North Fork at stream mile 9.9 with a base flow of less than one cfs. Spring Creek has with a history of irrigation impacts (dewatering and entrainment) to WSCT and fish passage problems 
(undersized culvert) affecting the upstream movement of juvenile bull trout. The recovery of the Spring Creek fish populations began in 1998 with the installation of a new irrigation diversion retrofitted with a fish ladder at mile 1.8. In 2000, we replaced an undersized culvert (mile 0.5) with a baffled culvert that Plum Creek Timber Company donated. The culvert was designed to pass YOY bull trout.

\section{Fish Populations}

Spring Creek is the only direct tributary to the lower North Fork that provides WSCT reproduction. Spring Creek supports WSCT over its length and low densities of brook and bull trout in lower reaches.

In 2000, we sampled fish populations at both project areas in order to evaluate 1) WSCT entrainment in an irrigation ditch (mile 1.8), and 2) culvert affects on juvenile bull trout movements (mile 0.5). The upstream survey at the diversion site recorded a total WSCT CPUE of 15.4 (above) and 16.5 fish 100 ' below the diversion. Total CPUE was 8.9 in the irrigation ditch; most were YOY (Appendix A). The downstream surveys taken above and

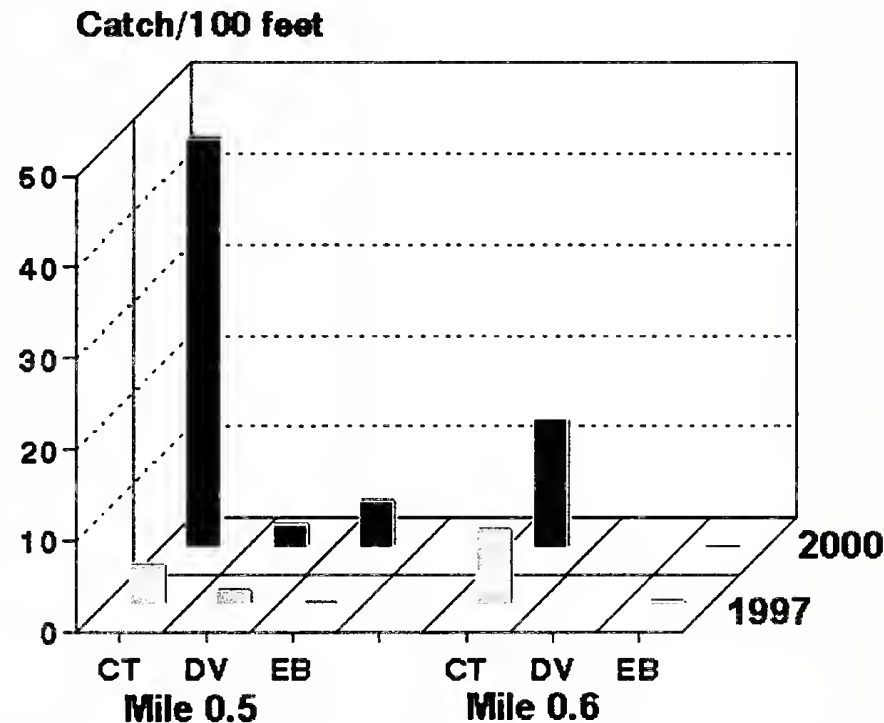

Figure 63. CPUE for all fish captured above (mile 0.6) and below (mile 0.5) a culvert on Spring Creek, 1997 and

below the culvert confirmed low flow passage problems for juvenile bull trout originally identified in 1997 (Figure 63). We also recorded large increases in WSCT below the culvert in 2000 compared to 1997 . Extremely low flow conditions $(\sim 1 / 4 \mathrm{cfs})$ probably triggered upstream movement resulting in concentrated densities in the pool below the culvert. During the drought of 2000 , the water right holder increased instream flows during the peak drought period to help maintain fish populations.

\section{Warren Creek}

Restoration Objectives: Restore riparian vegetation and stream habitat for all life cycle stages of fish; improve spawning and rearing conditions; increase recruitment of trout to the middle Blackfoot River; moderate whirling disease.

\section{Project Summary}

Warren Creek, a small tributary to the middle Blackfoot River, originates on Ovando Mountain, flows 12 miles southwest flows through knob-and-kettle topography, alluvial outwash plains, and ranchlands to its junction with the Blackfoot River at river mile 50. Warren Creek water is used for irrigated hay production and livestock watering. Irrigation withdrawal causes the middle section of Warren Creek to dewater, although the lower section is influenced by springs and maintains a perennial base-flow of 3-5 cfs. 
Some of the riparian areas in the mid-to-lower portion of the stream have been cleared, heavily grazed, dredged and straightened, the results of which have impaired salmonid habitat over most of the stream's length. Over the last decade, however, Warren Creek has also been the focus of a basin-wide water quality and fisheries improvement initiative (Pierce et al. 1997). To date completed projects include implementing riparian grazing systems, developing off-stream livestock watering, removing streamside feedlots and upgrading irrigation systems. Whirling disease has escalated in Warren Creek from mean grade infection of 0.2 in 1998 to 2.3 in 1999.

In 2000, we continued the restoration of lower Warren Creek with comprehensive restoration effort on 3.4 miles (stream mile 0.6 and 4.0) of stream. A major project element was natural channel reconstruction (Rosgen B, C and E-type channels) in an area of historic channel dredging. This project increased stream length $46 \%$ from $6,080^{\prime}$ to $8,870^{\prime}$ in a straightened section. Related projects included 1) building floodplain where high vertical banks accelerated bank erosion, 2) livestock management changes (fences, well, offstream water), 3) replacement of an irrigation diversion, 4) instream woody debris placement and streambank shrub plantings, and 6) restoration of two drained wetlands. Water conservation and instream flow enhancement should be implemented in 2001.

A stream temperature study in the summer of 2000 found maximum summertime stream temperatures approaching $74{ }^{\circ} \mathrm{F}$ (Appendix I).

Catch/100'

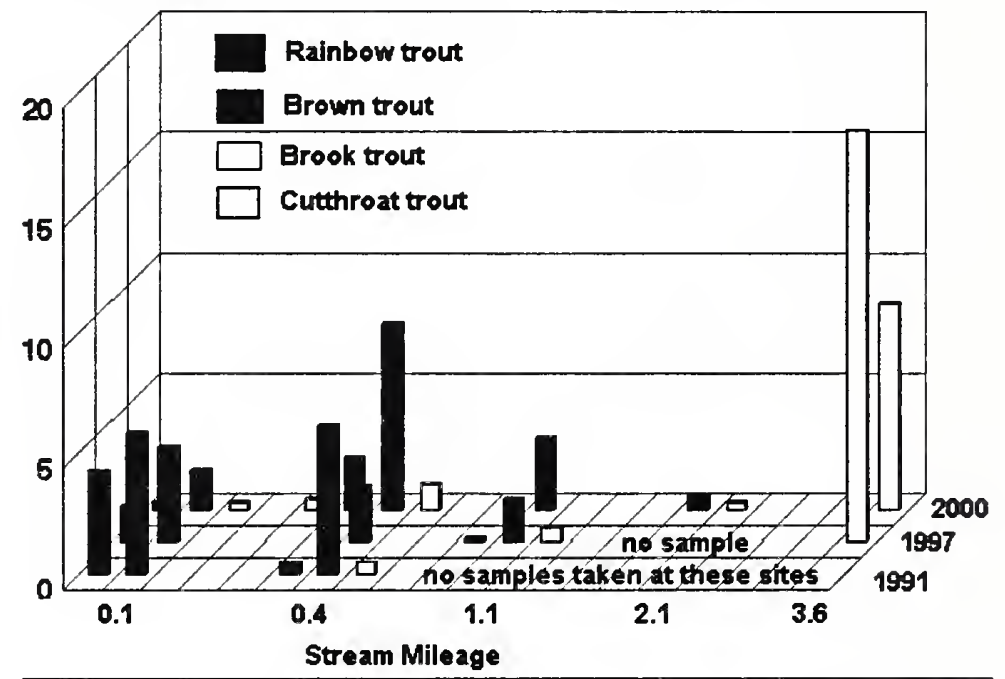

Figure 64. CPUE for fish $>4.0$ " at five sampling locations in lower Warren Creek, 1991, 1997 and 2000.

\section{Fish Populations}

Warren Creek enters the Blackfoot River in a river reach that suffers recruitment problems. Weak recruitment results from high winter mortality of juvenile fish and the lack of quality spawning tributaries entering this river reach. Warren Creek is the only stream within a 14-mile section of the Blackfoot River between Monture Creek to Rock Creek, (trib. to the North Fork) with increased spawning, rearing and recruitment potential for the Blackfoot River.

Low numbers of brown trout, rainbow trout and brook trout inhabit Warren Creek, along with very low numbers of WSCT. Brook trout dominate the headwaters along with low numbers of WSCT. Lower reaches support low densities of rainbow trout, brown trout and brook trout, and very low WSCT densities. 
Fish population investigations in 2000 focused on sampling stations established in $1991(0.1,0.4,1.1$ and 3.6) on lower Warren Creek. In 2000 we also established one additional survey site at mile 2.1 . These four survey sites are all located in reaches influenced by the year 2000 restoration project. All surveys found low juvenile fish densities. Populations continued a trend of declined in the lowermost survey section (Figure 64).

We also re-surveyed an upstream monitoring section (mile 8.2) established in 1995 in a degraded (F-type) channel prior to riparian livestock management changes (Pierce et al. 1997). Under new grazing management, the channel evolved from an $\mathrm{F}$ to a stable E-type channel. In 2000, we recorded increases in WSCT and a large increase in brook trout at this site five years

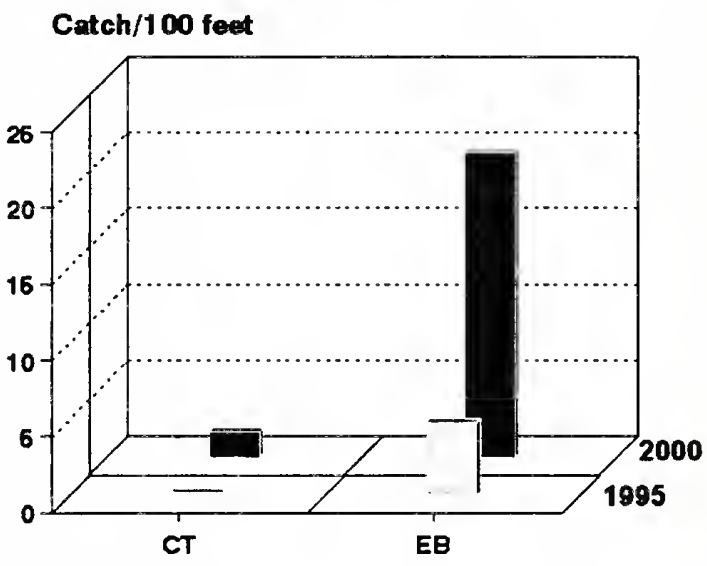

Figure 65. CPUE for salmonids (fish $>4.0$ ") in Warren Creek (mile 8.2), 1995 and 2000. post-project (Figure 65). 


\section{PART IV: ADDITIONAL AQUATIC INVESTIGATIONS}

\section{Tributary temperature Summary}

Tributary temperature monitoring for 2000 included 29 sampling sites on 17 tributaries. Of these 17 tributaries, nine are direct tributaries to the Blackfoot River, five of which originate in the Garnet Mountains. For these nine tributaries, we placed temperature sensors near their confluences with the Blackfoot River. We monitored temperatures on seven streams at duplicate 1999 sites (Pierce and Podner 2000).

Tributaries exhibit a wide range of thermal properties. In general, streams entering the Blackfoot River from the north exert a cooling influence on the river with the exception of the Clearwater River; whereas streams entering from the south approach ambient river temperature or in some cases exert a warming influence on the Blackfoot River. For August 2000, mean maximum water temperature for four south flowing streams (Gold Creek, Belmont Creek, Monture Creek and North Fork) was $67.6^{\circ} \mathrm{F}$ (range 64.4- 70.5 ${ }^{\circ} \mathrm{F}$ ). This represents a $3.5^{\circ} \mathrm{F}$ increase over 1999 temperatures for these stream (Pierce and Podner 2000). For 11 Garnet Mountain streams, mean maximum temperature was $73.3^{\circ} \mathrm{F}$ (range $67.0-78.0^{\circ} \mathrm{F}$ ) with maximum warming occurring in the first week of August.

For August, nine of 11 Garnet Mountain streams exceeded $>70^{\circ} \mathrm{F}$ (Figure 66). Five of these 11 Garnet Mountain streams directly enter the Blackfoot River. In the upstream direction they are Elk Creek (mile 28.7), Chamberlain Creek (mile 43.9), Wales Creek (mile 60.2), Yourname Creek (mile 65.3) and Nevada Creek (mile 67.8). The three upper tributaries enter the Blackfoot River upstream of the North Fork in a river reach with elevated summer water

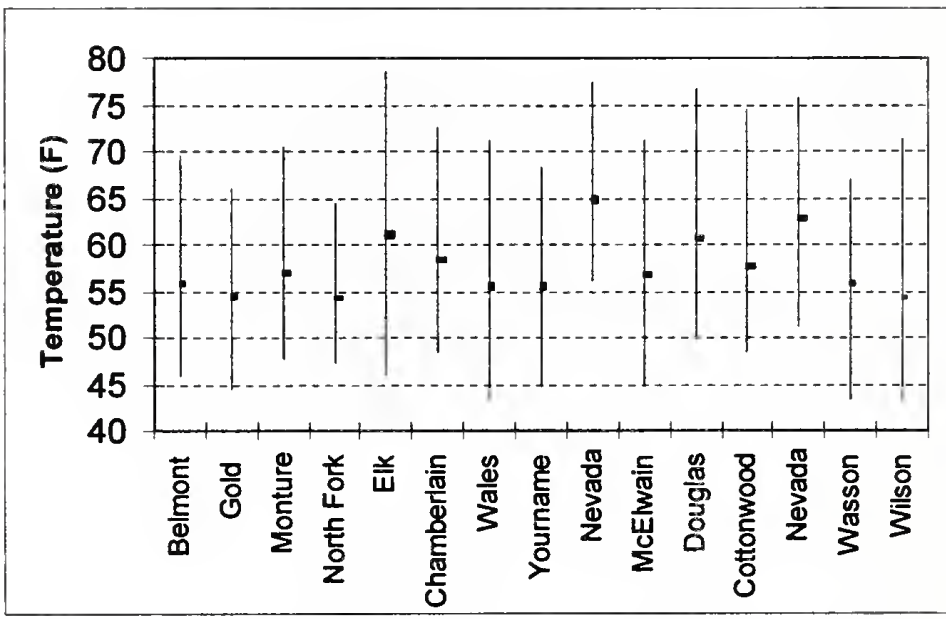

Figure 66. Mean, maximum and minimum stream temperatures for 15 Blackfoot River tributaries, August 2000. temperatures. Nevada Creek (mile 67.8) contributes to this temperature increase with maximum August water temperatures $7.1^{\circ} \mathrm{F}$ warmer than the Blackfoot River at the Cutoff Bridge monitoring site (mile 69.0). Maximum August temperatures for Yourname Creek and Wales Creek were $9.1^{\circ} \mathrm{F}$ and $6.3^{\circ} \mathrm{F}$ lower than Nevada Creek, within one degree $\mathrm{F}$ of maximum River temperatures at the Cutoff Bridge, but $\sim 6-8^{\circ} \mathrm{F}$ lower than the Blackfoot River at Raymond Bridge (mile 60.0).

Between the Raymond Bridge Section and the Scotty Brown Bridge, we monitored water temperatures for two large south flowing tributaries to the Blackfoot River: Monture Creek (mile 44.2) and the North Fork (mile 54.1). Maximum August temperature for the North Fork was 64.4 degrees-2.9 degrees higher than August 1999, 
but $12.2^{\circ} \mathrm{F}$ cooler than the Blackfoot River at Raymond Bridge. Monture Creek in August 2000 was $70.5^{\circ} \mathrm{F}-4.7^{\circ} \mathrm{F}$ warmer than 1999 .

Between the Scotty Brown Bridge (mile 45.0) and Corrick River Bend (mile 20.0) monitoring stations, we collected temperatures for three tributaries: Chamberlain Creek (mile 43.9), the Clearwater River (mile 34.8) and Elk Creek (mile 28.0). We placed four temperature sensors in the Chamberlain Creek drainage (East Fork-mile 0.1, West Forkmile 0.1, mouth-mile 0.1, and upstream of the West Fork-mile 3.9). Between the West Fork and the mouth, the mainstem Chamberlain Creek increased $10.1^{\circ} \mathrm{F}$ from $62.8^{\circ} \mathrm{F}$ (mile 3.9) to $72.5^{\circ} \mathrm{F}$. Water from Chamberlain Creek entered the Blackfoot River at near ambient with at the Scotty Brown Bridge monitoring site. For the Clearwater River, maximum August temperatures were $75.7^{\circ} \mathrm{F}$ or $3.0^{\circ} \mathrm{F}$ higher than the Blackfoot River at Corrick River Bend and $4.9^{\circ} \mathrm{F}$ higher than the Scotty Brown Bridge monitoring station. Elk Creek, the lower-most Garnet Mountain stream, reached a high of $78.5^{\circ} \mathrm{F}$ or $5.8^{\circ} \mathrm{F}$ higher than the Blackfoot River at Corrick River Bend.

We monitored stream temperatures in two additional south flowing streams to the lower Blackfoot River: Gold Creek (mile 13.9) and Belmont Creek (mile 21.9). Both stream recorded cooler temperatures than the lower Blackfoot River. Gold Creek reached a high of 66.0 degrees $-7.5^{\circ} \mathrm{F}$ lower than the Blackfoot River near the mouth. Belmont Creek reached a high of $69.5^{\circ} \mathrm{F}$ or $4.0^{\circ} \mathrm{F}$ cooler the lower Blackfoot River.

\section{Blackfoot River Drought Management Strategies}

The lower Blackfoot River is one of twelve designated "blue-ribbon" streams in Montana with an appropriated "Murphy" in-stream flow water right. FWP holds a Murphy Right for the Blackfoot River with a priority date of 01-06-71 for two river reaches in the lower Blackfoot River. The upper reach extends from the junction of North Fork (mile 54.1) down river 19.4 miles to the mouth of the Clearwater River. The lower reach begins at the Clearwater River and extends 34.7 miles down river to mouth of the Blackfoot River. Although in-stream rights vary by reach and season, the lower reach with a $700 \mathrm{cfs}$ mid-summer instream Murphy right, measured at the Bonner gauging station (USGS \# 12340000), was used for drought planning. This $700 \mathrm{cfs}$ value, determined using standard instream flow methodologies (wetted perimeter), represents minimal summer stream flows necessary to preserve fish and wildlife habitat in the lower Blackfoot River (FWP report 1969). Below $700 \mathrm{cfs}$, FWP can make the "call for water" to water right holders junior to the Murphy right.

The Blackfoot Watershed emergency drought plan was developed to 1) minimize adverse impacts on fisheries, 2) provide an alternative to the traditional FWP call for water, and 3) aid in a more equitable distribution of water during low-flow periods. This voluntary plan, under the guidance of the Blackfoot Challenge, was based on the premise of "shared-sacrifice" in which all parties (agriculture, anglers, outfitters, homeowners, government agencies, and others) agreed to restrict water use when the Blackfoot River drops below $700 \mathrm{cfs}$. This plan relied on a set of three low-flow values used to "trigger" elements of the plan. They are:

1) $700 \mathrm{cfs}$ (Murphy in-stream right);

2) $550 \mathrm{cfs}$ (mid-range value between a one-in-five (602 cfs) and one-in-ten year (484 cfs) low-flow event);

3) $400 \mathrm{cfs}$ (below a one-in-twenty year (419 cfs) low-flow event). 
We also developed a set of supplemental water temperature triggers (maximum $>73^{\circ} \mathrm{F}$ for three days for the Blackfoot River, $>65^{\circ} \mathrm{F}$ for three days in bull trout streams) for used to restrict angler pressure in critical reaches during periods of severe temperature stress as needed. We began intensively monitor river temperatures in July. By early august, warming of the Blackfoot River and tributaries prompted FWP to call for voluntary angling restrictions on the lower 65 miles of the Blackfoot River and all bull trout core areas.

During drought plan implementation, 65 individual water conservation plans were developed and implemented. Individual contributions by water right holders helped maintain flows and fish populations in the Blackfoot River and segments of several tributaries. A critical plan component was a DNRC water resources coordinator, working one-on-one with irrigators to help develop water conservation plans during the peak drought period.

Irrigators and anglers, agencies and a dedicated community-based drought committee all contributed to drought plan success. Under the guidance of the Blackfoot Challenge, agencies (FWP, DNRC, USFWS) contributed by: 1) identifying critical areas of dewatering and resource concern, 2) calling for closures of government diversions, 3) implementing restrictions on angling, 4) initiating media outreach, and 5) modifying the Murphy "call" with participating irrigators. Although the Plan helped offset drought impacts, the emergency sacrifices of water users combined with chronic and pervasive flow problems underscore the need for a comprehensive long-term Blackfoot Watershed drought strategy.

Through the 1990s, voluntary

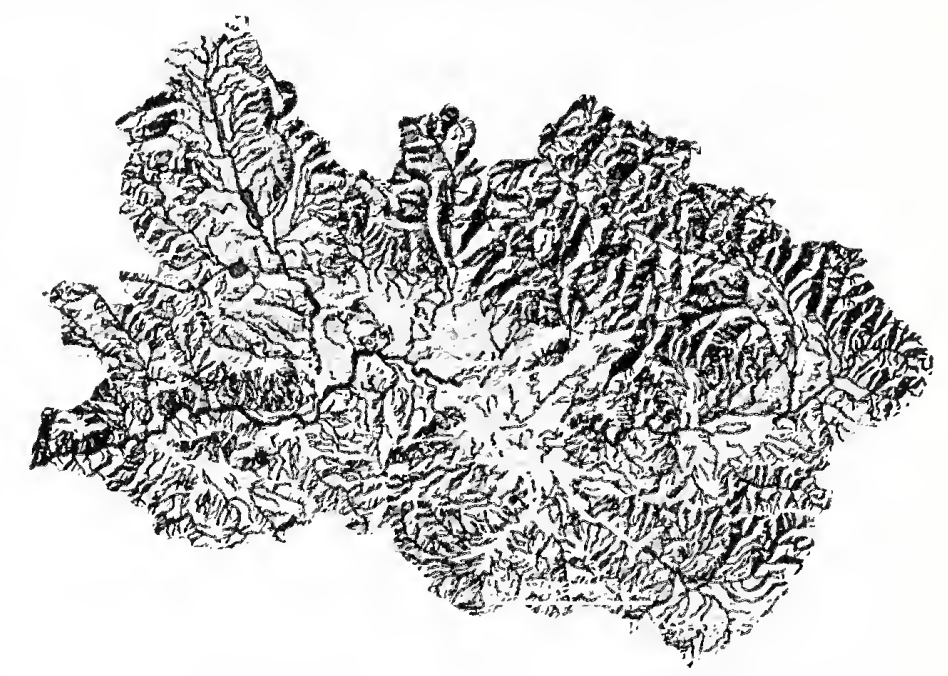

Figure 67. Generalized map of streams with potential for water conservation.

water conservation-a primary element of the Blackfoot River restoration program has augmented flows in 11 tributaries and enhanced Blackfoot River base-flows by $\sim 40-50$ cfs. Still as of 2000 , chronic dewatering remains a wide-spread resource problem with $42 \%$ (31 of 74) of inventoried tributaries now identified with potential for water conservation (Figure 67). In addition to widespread low flow problems, $57 \%$ (42 of 74) of inventoried streams have potential for improved riparian health (Appendix F). In areas where low flow and reduced riparian health and other identified problems overlap, longterm drought plans should consider more than just water conservation alone.

During our 2000 fish population monitoring, several restoration project streams recorded higher trout densities following the drought season-some in basin-fed streams subject to drought-related stressors. These population increases demonstrate the important role riparian health, habitat complexity and other restoration measures could exert in mitigating drought impacts to fish populations. On a broader scale, addressing 
flow problems within a context of limiting factors would not only moderate resident fish population declines, but also result in higher flows, improved water quality and reduced thermal stress in downstream reaches. Drought strategies that effectively address all limiting factors in tributaries would greatly improve resiliency of migratory stocks and increase recovery potential of Blackfoot River fish populations following periods of extreme drought.

\section{Recreational Impacts to Blackfoot fish Populations}

Recreational impacts to fisheries vary spatially, and include illegal introductions of unwanted fish species and upward trends in angling pressure in critical native fish recovery areas. For the mainstem Blackfoot River, recreational impacts generally relate to trends in angling pressure and impacts to fluvial native trout (WSCT and bull trout), both of which are now in the early stages of recovery in some areas of the watershed.

\section{Species of primary concern: bull trout and westslope WSCT}

Bull trout

Bull trout, a "threatened" species under the Endangered Species Act (ESA), occupies a limited distribution within the Blackfoot Watershed, which includes approximately 110 miles of the Blackfoot River mainstem and approximately 340 miles of tributaries. Fluvial bull trout habitat includes the mainstem Blackfoot River as "nodal" habitat (migratory corridors, overwintering areas) and 7 major "core" area (spawning and rearing areas) tributaries to the Blackfoot River. Although seven tributaries support

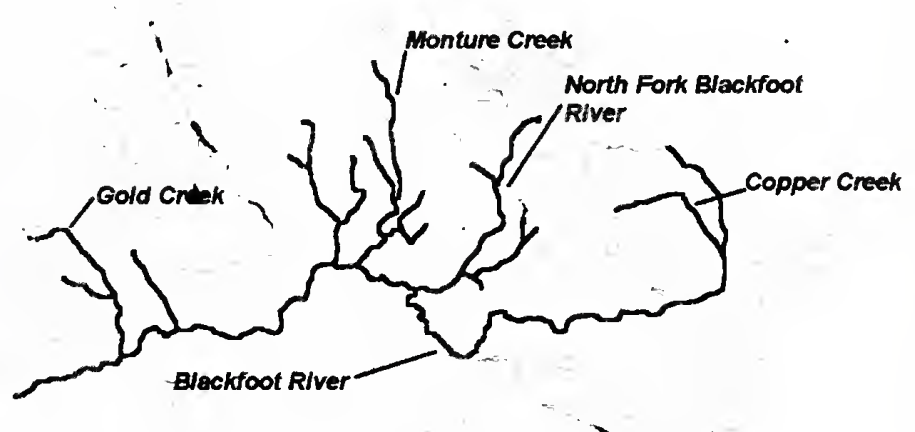
reproducing populations of fluvial bull trout, radio-telemetry studies indicate $>90 \%$ of fluvial bull trout reproduction occurs in localized reaches of three tributaries: Monture Creek, the North Fork of the Blackfoot River and Copper Creek (Figure 68). Monture Creek and the North Fork of the Blackfoot River represent crucial bull trout habitat for the lower Blackfoot River population. These stream are not only important for spawning and rearing, but also for adult staging, thermal refuge and migration corridors for the majority of the Blackfoot Watershed bull trout population. Copper Creek supports the only significant spawning run from the upper Blackfoot River bull trout population.

The Blackfoot River supports recoverable populations of bull trout. Although densities in the lower-river population (North Fork to mouth of Blackfoot River are now improving, the status of Blackfoot River bull trout remains precarious and "at risk" over most of its range within the Blackfoot watershed (Thomas 1992). Populations of lakedwelling (adfluvial) bull trout in the Clearwater drainage have shown major declines due to illegal introduction of northern pike. 
Reaches of the middle Blackfoot River, specifically between the Clearwater River and the North Fork Blackfoot River provide critical life history requirements for most of the Blackfoot River bull trout population. In conjunction with spawning and rearing in Monture Creek and the North Fork Blackfoot River, the majority of Blackfoot River bull trout use this river reach for migration corridors and/or overwintering areas. In addition, this reach supports summer concentrations of bull trout near the confluences of Monture Creek and the North Fork.

The Montana Bull Trout Recovery Plan (FWP 2000) has identified angling pressure as both a risk (factor contributing to past and current declines) and a threat (factor contributing to the future conservation) to bull trout in the Blackfoot Watershed. Bull trout are highly susceptible to certain type of angling methods including the use of bait (night crawlers, fish) and lures (spoons, crankbait, large "flashy" wet flies). Also large fish are susceptible to harvest in small streams and other areas of seasonal concentrations.

Impacts to bull trout, related to recreation are 1) large increases in angling pressure in critical population areas, 2) the inability of anglers (particularly non-residents) to identify bull trout, 3) poor understanding of fishing regulations for a large portion (36\%) of the angling public, and 4) unacceptable levels of illegal bull trout harvest.

\section{Westslope cutthroat trout}

Within the last 100 years, WSCT have declined throughout much of their historic range. This decline lead to their status as a "species of special concern" in Montana. At this time, a federal court is reviewing a petition to list WSCT as Threatened under the ESA. In the Blackfoot Watershed, WSCT are distributed but have been displaced from many tributaries. However, the fluvial life history form is generally at low densities. Fluvial WSCT is now at an early recovery phase in mid-to lower reaches of the Blackfoot River (mouth to the North Fork).

WSCT are very susceptible to all types angling (including flies, bait and hardware), making this fish more vulnerable to angling than other trout species. In a 1999 creel survey of the Blackfoot River, anglers captured more WSCT than any other species (Schmetterling and Bohnemann 2000), despite that they are not the most abundant fish. Incidence of hooking scars appear to be increasing and currently range as high as 60 $70 \%$ for adult WSCT in some reaches of the Blackfoot River. Concern for WSCT relate to the steep upward trend in angling pressure, combined with a perceived increase in physical damage to released fish due to poor handling practices and repeated capture.

\section{Angling pressure increases}


Every two years, Montana Fish, Wildlife and Parks completes a statewide angler pressure estimate survey. For this survey, the Blackfoot River is divided into three reaches: 1) mouth to the Clearwater (mile 0-34.8); 2) Clearwater to Arrastra Creek (mile 34.8-88.8); and 3) up river of Arrastra Creek (mile 88.8 to 132.0). Over the last decade (1989 through 1999), total angler pressure estimates for the Blackfoot River increased $186 \%$ from 16,229 to 46,385 angler days. Although substantial increases have been documented over the length of the Blackfoot River, reach 2 (Clearwater to Arrastra Creek) has experienced the highest rate of increased angler use, up $540 \%$ from 2,514 angler days in 1989 to 16,081 angler days in 1999 (Figure 69).

Although residents still comprise the majority of anglers, nonresident angling pressure increased at approximately double the rate of resident angling pressure. From 1989 through 1999, non-resident pressure increased $440 \%$ compared to a $137 \%$ for residents. The highest rate of increase for non-resident anglers occurred in reach 2 up 1,135\% from 460 angler days in 1989 to 5,682 angler days in 1999 (Figure 70). This angling pressure is not evenly distributed within reach 2 , but rather concentrated in a 19.3-mile reach between the North Fork and Clearwater River. This pressure overlaps with a critical native fish recovery area. Pressure increases in appear to be expanding to the larger tributaries to reach 2 , which include two critical bull trout recovery areas (Monture Creek and the North Fork).

Anglers inability to identify bull trout and other salmonids

Recreational impacts relate not only to upward trends in angling pressure in critical recovery areas but also the inability of a large percentage of anglers to properly identify fish species. A survey conducted in 1995-

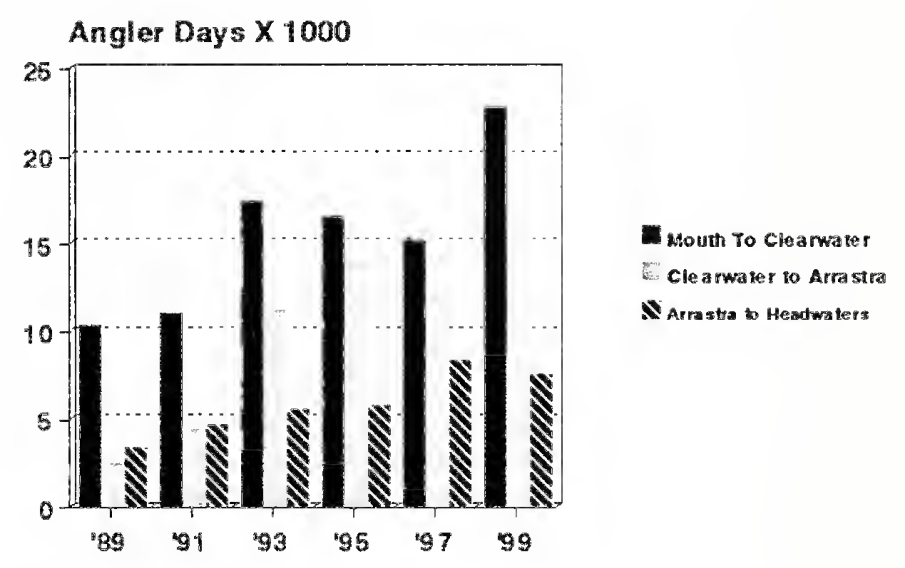

Figure 69. Total Angler pressure for three reaches of the Blackfoot River, 1989-1999.

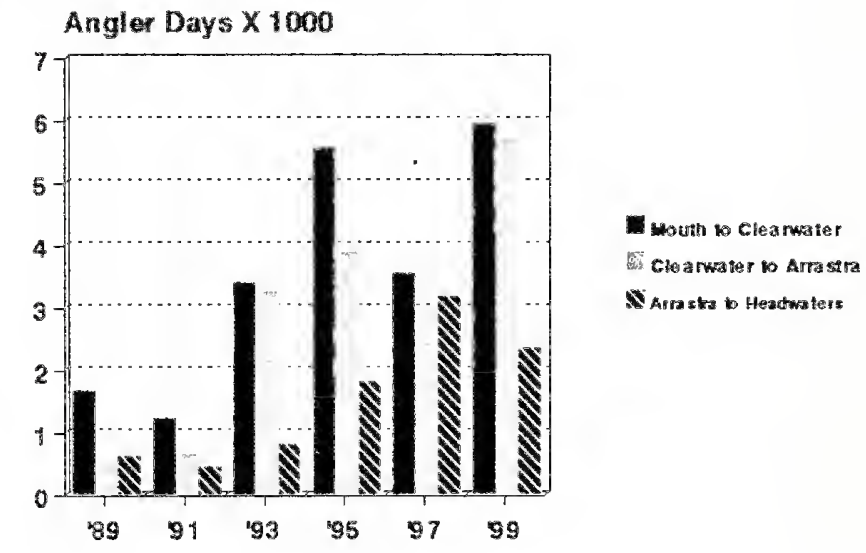

Figure 70. Non-resident angler pressure for three reaches of the Blackfoot River, 1989-1999.

1996 of anglers fishing on the rivers and streams on western Montana found that $43 \%$ of resident anglers correctly identified bull trout compared to only $22 \%$ non-resident anglers (Schmetterling and Long 1999). Anglers correctly identified brook trout $49 \%$ of the time (Schmetterling and Long 1999). The 1999 Blackfoot River creel survey found that only $33 \%$ of surveyed anglers $(\mathrm{N}=312)$ correctly answered bull trout identification questions, 
while $64 \%$ of surveyed anglers $(\mathrm{N}=323)$ correctly answered the questions regarding bull trout fishing regulations (Schmetterling and Bohnemann 2000).

The inability of anglers to identify bull trout and other species, combined with a generally poor understanding of fishing regulations results in non-compliance with angling regulations and the unintentional illegal harvest of bull trout. Two telemetry studies found between 5-14\% of radioed bull trout were illegally harvested (Swanbergpersonal communication, Schmetterling and Liermann 2000). In the 1999 Blackfoot River creel survey, 570 anglers (1.2\% of the 1999 estimated anglers) reported 3 of 39 bull trout captured were kept (Schmetterling and Bohnemann 2000). Although bull trout were caught less frequently, they were harvested at a higher rate (8\%) compared with the overall rate of $5 \%$, which includes mountain whitefish. Brook trout were the only species harvested at a higher rate than bull trout. Although anglers reported capturing more brook trout than bull trout, fish population surveys report brook trout rare to absent over the length of the Blackfoot River. The high percentage of "brook trout" kept combined with the inability of anglers to correctly identify brook and bull trout suggests additional unintentional bull trout harvest than reported in the 1999 creel survey.

Although Blackfoot River westslope WSCT were correctly identified nearly $80 \%$ of the time (Bohnemann and Schmetterling, 2000), this species is more readily caught by anglers, making it potentially more vulnerable to 1) harvest, 2) damage due to repeated capture, and 3) release mortality (Schmetterling and Long 1999).

\section{Public access sites in critical native fish recovery areas}

At this time, recreational impact concerns are species specific (bull trout and WSCT), and specific important native species recovery areas within the watershed.

Large increases in recreational pressure combined with the inability of anglers to identify fish species is causing concern for bull trout in critical habitats and other local recovery areas in the Blackfoot Watershed. Of particular concern is the combination of current and proposed recreational access sites located in important bull trout recovery areas.

Access/recovery conflict areas include recreational access sites in key spawning, rearing and staging areas, as well as thermal refuge areas on reaches of Gold Creek, Belmont Creek, Monture Creek, Copper Creek, the Landers Fork, the North Fork of the Blackfoot River and sections of the middle Blackfoot River (Figure 71). These conflict areas: 1) overlap recreational developments in areas of concentrated bull trout use; 2) support substantial increased angler use in some areas; and 3) have documented illegal bull trout harvest problems.

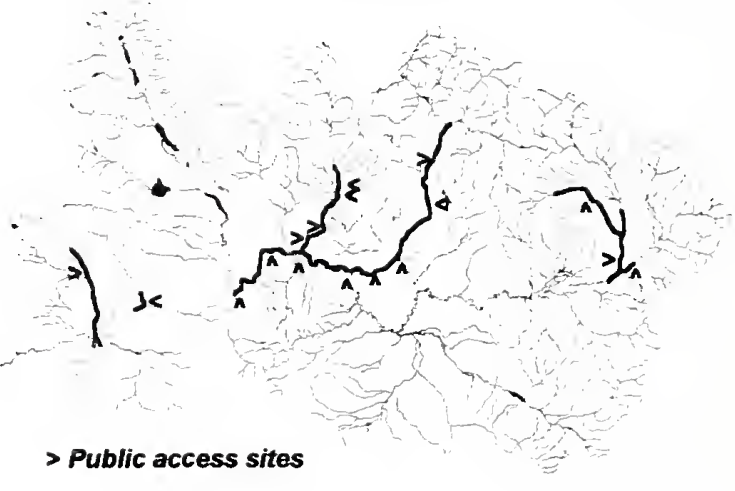

Figure 71. Bull trout recovery/recreational conflict areas.

Public access sites (Fishing Access Sites, trailheads, campgrounds, etc.) are found at all four major bull trout spawning locations in the Blackfoot Basin. In addition, Fishing Access Sites and other public access facilities are located in three (Monture 
Creek, Gold Creek, and North Fork Blackfoot River) principle bull trout thermal refuge sites near the mouths of these tributaries. Fishing Access Sites are located at all major thermal refuge areas on the mainstem Black foot River, including the confluence of Gold Creek, Belmont Creek, Monture Creek, and the North Fork Blackfoot River. To the potential detriment of bull trout, proposed recreational development have surfaced for the confluence areas of Gold Creek, Belmont and Monture Creeks. These and all additional future recreational developments in critical recovery areas need to consider consequences to bull trout recovery at early planning stages.

\section{Illegal introductions of fish species}

The waters of the Blackfoot River drainage are frequently placed at jeopardy by unwanted illegal introductions of fish and other organisms. These introductions are often achieved by well-intended fisherman but can result in disastrous unintended consequences.

Introductions of exotic species represent one of the largest threats to the conservation of native fish species in the Montana. Introduction of whirling disease (Myxobolus cerebralis) in many Montana waters, Mysis shrimp (Mysis relica) in Flathead Lake, and northern pike (Exos lucius) in the Blackfoot Watershed represent only a few recent examples of the threat that exotic species pose to native fishes. In the last 6 years, illegal introductions of four exotic fish species have been documented in the Blackfoot Watershed, resulting in reproducing populations of northern pike, yellow perch, white sucker and fathead minnow.

\section{Northern Pike}

The introduction of northern pike to the Clearwater Chain of Lakes (tributary drainage to the Blackfoot River) provides a profound example of the alarming impact illegal introductions can have on an existing sport fishery. Lakes in the Clearwater River drainage provide a sport fishery for kokanee, rainbow trout and brown trout. The introduction of northern pike has reduced numbers of all trout and sport fish. After the introduction of northern pike, mountain whitefish have been reduced by $32 \%$ in highdensity pike lakes, kokanee by $60 \%$, WSCT by $66 \%$, and bull trout have declined by $82 \%$ (Rod Berg, personal communication). Unfortunately, northern pike select for bull trout, which have experienced the most drastic declines. If bull trout, WSCT, kokanee and other species are to be revived in the Clearwater River drainage, long-term control or eradication of pike is essential. This may require diversion of hundreds of thousands of dollars of Montana Fish, Wildife and Parks revenues which otherwise could be been spent on more appropriate programs such as fish habitat enhancement, fishing access sites acquisition, or hatchery supplementation.

Northern pike from the Clearwater Chain of Lakes have dispersed into the lower Blackfoot River and Milltown Reservoir, located at the mouth of the Blackfoot River. Fish population sampling in the lower Blackfoot River has recorded an upward trend in northern pike numbers over the last six years although densities currently remain low. However, northern pike densities in Milltown Reservoir are very high. Northern pike is now the most abundant fish in the reservoir (biomass and numbers). Impacts include large declines in native non-game fish species. Predation on out-migrant Blackfoot River mountain whitefish, rainbow trout, WSCT and bull trout is also occurring. In May 2000, 
juvenile bull trout were the most abundant species in the stomachs of northern pike (Schmetterling 2001).

\section{Yellow Perch}

Illegal introductions of yellow perch in Nevada Reservoir and Upsata Lake have resulted in a self-sustaining population of "stunted" fish. In Nevada Reservoir as a result of competition, a put, grow-and-take rainbow trout fishery has shown a significant reduction in condition factor and growth rates, making these fish less desirable to the angling public. Recreational impacts related to perch introductions have not only resulted in reduced angling opportunity for large rainbow trout, but have also decreased the quality of the fishery (Wayne Hadley, personal communication). After perch were established, the population generally "stunts" (mean size 5") and offers little recreational value.

\section{White Sucker and Fathead Minnow}

Introductions of white sucker and fathead minnow probably resulted from anglerreleased baitfish. Although poorly understood at this time, illegal introduction of white sucker may result in competition and/or hybridization with native species (largescale and longnose sucker). White suckers are now found throughout the Blackfoot Watershed. Competition between non-native fathead minnow and other species is likely. FWP observed reduced trout growth rates and survival in several northwest Montana lakes due to competition with introduced fathead minnows. The potential for transfer of exotic pathogens and diseases through these illegal introductions is an unknown, but legitimate concern.

\section{Summary}

Recreational impacts are now contributing additional challenges to the recovery and conservation of native fish species in some areas of the Blackfoot River watershed. For the Blackfoot River pervasive bull trout misidentification, large increases in angler pressure in critical recovery areas, and angler non-compliance with bull trout regulations has been well-documented (Schmetterling and Long 1999, Swanberg 1997, Schmetterling and Bohnemann 2000). For fishing regulations to be effective, anglers need to know and understand regulations as well as identify fish correctly. While the legal harvest of both bull trout and WSCT has been restricted and/or eliminated in the Blackfoot Watershed, anglers are harvesting bull trout in part because of their inability to identify them (Schmetterling and Long, 1999). Illegal harvest of large bull trout also continues in areas of seasonal concentrations (personal observation). In 2000, one of seven large radioed bull trout was illegally harvested from lower Monture Creek (Schmetterling and Liermann 2000). To date, bull educational efforts targeting bull trout identification have largely been ineffective for particularly non-resident anglers (Schmetterling et al 2000).

In 1999, Blackfoot River bull trout were harvested at a higher rate than other species. If trends in angler pressure and developments in critical habitats continue, excessive illegal bull trout harvest may not only slow bull trout recovery, but also likely delay bull trout de-listing. 
The Montana Bull Trout Recovery Plan has also identified sport fishing in bull trout habitat as negatively impacting populations in the Blackfoot Watershed. When sport-fishing impacts to bull trout occur, the Montana Bull Trout Recovery Plan states that, "management should be thoroughly reviewed, and modified and implemented where necessary to conserve bull trout. Sport fishing management needs to include additional angler educational component and must be better enforced. In waters where sport fishing management goals are in conflict with bull trout restoration goals, sport fishing goals should be modified to emphasize protection and restoration of bull trout."

In addition to education and enforcement options, both fisheries and recreational management goals need to consider critical recovery areas, including staging and spawning areas during periods when bull trout are vulnerable. Recreation/recovery conflicts areas have been identified. Delineation of "Native Species Management Areas" which emphasized protection and recovery of native salmonids are now being developed by FWP Fisheries staff. These designations should also help identify areas where conflict is occurring between recreational growth and native species recovery and protection. Development of the Blackfoot River Management Plan should also aid in reducing recreational/native fish recovery conflicts. Currently, the U. S. Fish and Wildlife Service has ESA management authority over bull trout and should assist in bull trout-related recreational planning/development efforts, and specifically help address bull trout/recreational conflicts in critical recovery areas.

Angling pressure increases contribute to an upward trend in damage (hooking scars) to WSCT, which has shown a higher susceptibility to angling than other species. Rather than resulting in population declines, current recreational impacts to WSCT relate to trends of exploitation, poor handling, and related damage to an important native fish. Poor fishing practices causing excessive injury potentially have significant future recreational impacts. Excessive damage resulting from poor handing and repeated capture may help legitimize an emerging animal-rights movement, and potentially damage recreational fishing by negatively affecting public sentiment toward sport fishing.

Efficacy of Three Denil Fish Ladders for Low Flow Fish Passage in Two Tributaries to the Blackfoot River, Montana. By D. A. Schmetterling, R. W. Pierce, and B. W. Liermann.

In order to evaluate fish passage at three Denil fish ladders in Chamberlain Creek and Cottonwood Creek, we captured fish upstream of the ladders, marked them and released them downstream. We also repeated this procedure for fish in three nearby stream reaches without a ladder (control group). All salmonids were adipose clipped and marked with a visible implant fluorescent elastomer tag in the adipose tissue behind the eye. Slimy sculpins (Cottus cognatus, mean length 3.0" SD 0.6, range 1.8-4.8) were only marked with a VIE tag on the ventral side of the mandible, an area of low pigmentation (right side for treatments, left side for control). After handling, fish were released downstream of the shocking section. There were no significant differences between lengths of fish captured in treatment and control sites. We re-sampled the sections 5-7 days after marking and recaptured approximately $25 \%$ of marked WSCT and brown trout (Salmo trutta) in both treatment and control sections. Overall fish were recaptured in the same number between treatment and controls for all sites. The fish ladder in 
Chamberlain Creek was 8.0' long and gained 1.3' in elevation. Mean velocities ranged from $0.6-2.7 \mathrm{ft} / \mathrm{s}$ (grand mean $1.7 \mathrm{ft} / \mathrm{s}$ ) measured at each slot. WSCT whose lengths ranged from 3.66.8 " were recaptured after ascending the ladder and were similar to recaptures in the control reach. The ladder on lower Cottonwood creek was $20.0^{\prime}$ long, and gained $2.0^{\prime}$ in elevation. Mean velocities ranged from $0.4-$ $2.4 \mathrm{ft} / \mathrm{s}$ (grand mean $0.7 \mathrm{ft} / \mathrm{s}$ ) but brown trout recaptures in the treatment section were significantly larger (range 8.5-13.9") than in the control reach (range

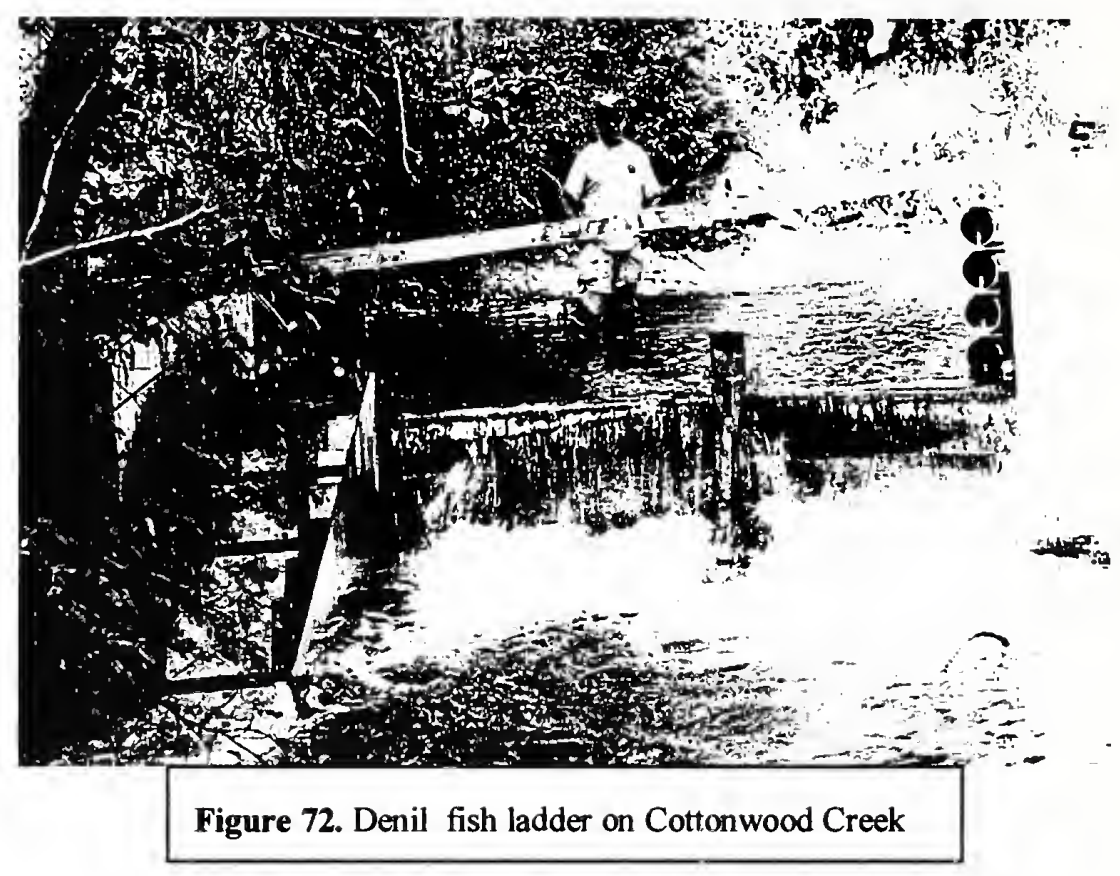
4.6-13.6) and suggest that the ladder impeded smaller fish. The ladder at the upper Cottonwood Creek site was 11.8' long and gained 2.0' in elevation, had the steepest slope and greatest velocities (range 0.9-4.6, grand mean 1.9ft/s). However, WSCT sizes and number of recaptures did not differ between treatment (length range 6.5-12.4") and control reaches. No slimy sculpins were recaptured in either the treatment or the control sections. Although these ladders demonstrate promise for passing fish of various sizes over irrigation diversions, fish ladders on irrigation diversions require maintenance. When evaluating these structures, only one of four Denil fish ladders was maintained and operating correctly. Landowner commitment to periodic maintenance of these structures clearly needs to improve if these structures are to meet fish passage objectives.

An evaluation of WSCT impingement on a turbulent fountain fish screen on McCabe Creek By Ron Piece and Greg Neudecker.

Fish losses to irrigation ditches remain a widespread welldocumented problem in the Blackfoot River watershed. In 2000, we tested the effectiveness of a turbulent fountain diversion for screening WSCT using two independent methods. These

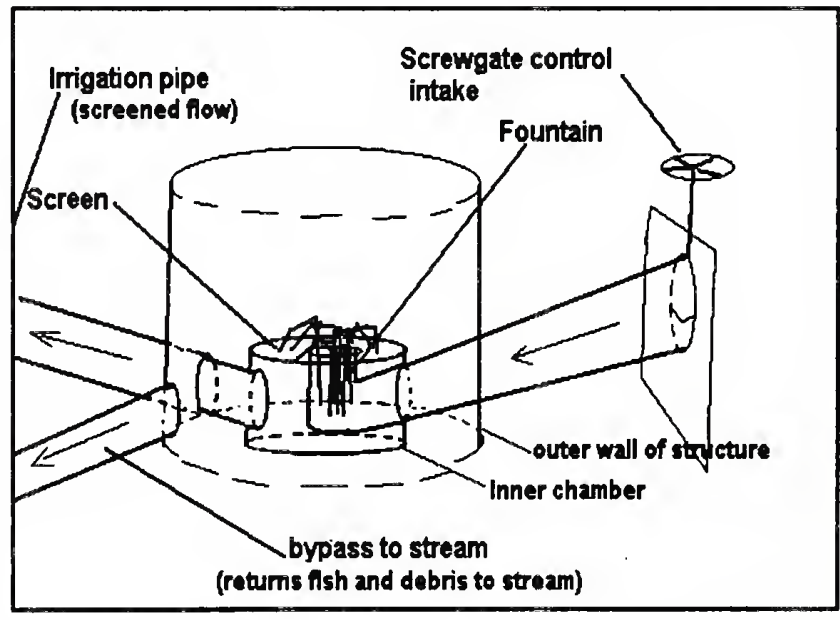

Figure 73. Conceptual design of a turbulent fountain fish screen. 
evaluations relied on 1) fish population density estimates upstream of the diversion before (1999) and after (2000) the installation of the fountain screen (see Results Part III, McCabe Creek), and 2) an evaluation of fish impingement to the screen.

A turbulent fountain fish screen is an integrated diversion structure designed to meet several irrigation objections: 1) volume control (to a center pivot in this case), 2) automatic removal of debris prior to water entering the pipeline, and 3) reducing fish losses to the irrigation system. Unlike other self-cleaning fish screens, the turbulent fountain has no moving parts but instead works entirely from hydraulic pressure. Hydraulic differential between the intake and the fountain is therefore a necessary design consideration. (Figure 73).

In order to evaluate impingement, we captured 48 WSCT immediately upstream of the fountain. Fish were anesthetized (MS-222), measured for total length, and weighed. Following recovery from the anesthetic, fish were individually sent through the fountain intake. We assessed impingement by recording the number and total length (visually estimated to the nearest inch) of fish impinged ( $\geq 2$ seconds) on the screen. We also recorded the amount of time required for impinged fish to free

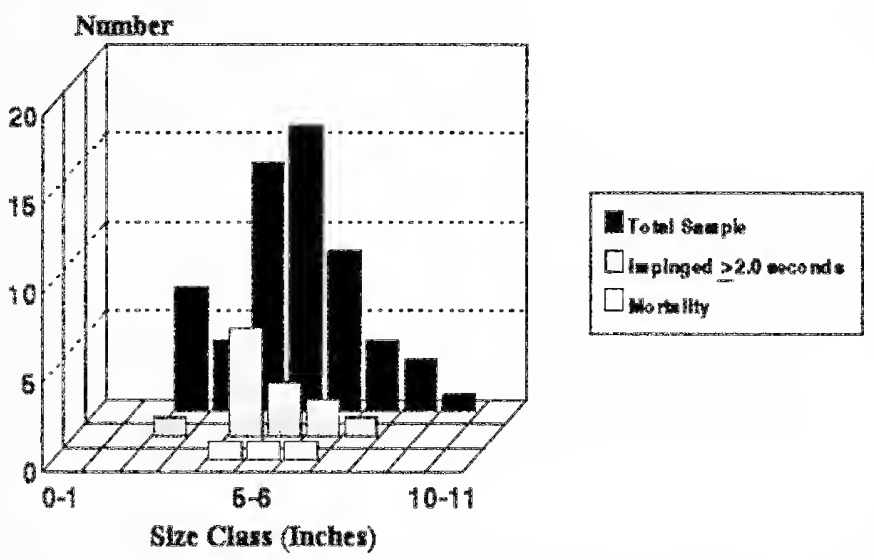

Figure 74. Length frequency of total sample, impinged fish ( -2.0 seconds) and mortality.

themselves from of the screen. During this experiment, the fountain was operating a full capacity.

Of the 48 fish sent through the fountain, thirty one $(65 \%)$ immediately passed through the fountain with no impingement ( $\leq 1$ seconds) on the screen. The remaining $35 \%(n=17)$ of fish were impinged for $\geq 2$ seconds. Of these 17 fish, 14 managed to work free of the screen (mean time $=7.4$ minutes (range 2 seconds to 26 minutes). Fish impinged for extended periods were kept alive by turbulent constant splashing of water over the fish. Only $6 \%(\mathrm{~N}=3)$ of the sampled fish were unable work free from the fish screen after 40 minutes; these fish were considered mortalities for the purposes of this study. We found no clear relationship between fish length and impingement (Figure 74). Upon

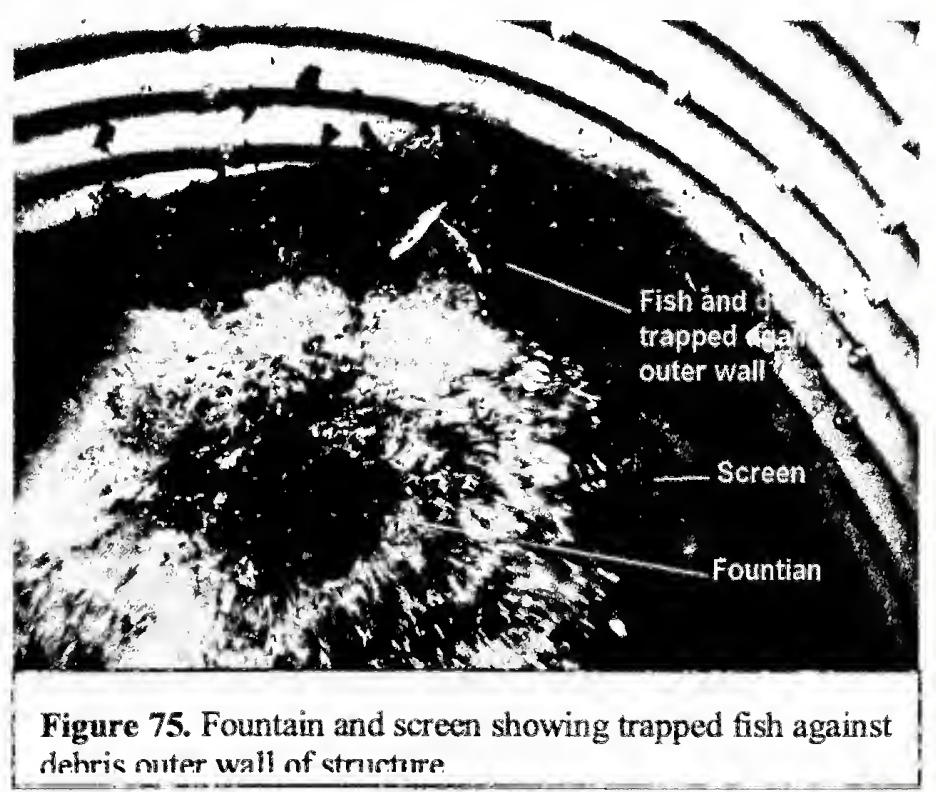


completion of the experiment, we walked the stream up-and downstream of the bypass and found no additional mortality.

Impingement relates to design and construction considerations, several of which could be modified to reduce or even eliminate fish losses. All fish impinged were found on the outer portion of the screen within an approximate 90-degree arc. This area of impingement occurred where the screen and outer wall of the structure came in contact (construction flaw). Because of this contact, the fountain was unable to completely wash debris, and fish trapped against the debris, from the screen (Figure 75). A design consideration for future screening should include a sloped, rather than horizontal, screen angle. Not only does a flat screen lend itself to impingement, several fish once on the screen, attempted to swim towards the flow (center) of the fountain; these fish remained on the screen for a longer time period before escaping. A second design consideration would be a smaller diameter inner chamber requiring less screen surface area; this would allow more efficient cleaning, and reduce impingement on the outer portion of the screen. A larger intake with additional volume would serve the same purpose by washing fish from the outer portion of the screen. Lastly, it may be possible to elevate the bypass pipe and submerge the screen in order to reduce impingement. Incorporating any of these design modifications would reduce or possibly eliminate impingement. With these considerations, the turbulent fountain has potential as a cost-effective, low maintenance and efficient alternative to screening salmonids from small higher gradient irrigation ditches.

\section{Habitat evaluations in the upper Blackfoot River}

\section{Background}

The upper Blackfoot River supports a small population of fluvial bull trout, which appears to complete its life history in a smaller section of river than the lower river population (Swanberg and Burns 1997). Historically, this upper river bull trout was most likely at higher densities and better connected to the lower river population. The upper river population reproduces in Copper Creek (USFS unpublished data), and uses the Landers Fork as a migration corridor (Swanberg and Burns 1997). Rearing occurs primarily in Copper Creek and in adjoining waters to a lesser degree (Chapman and Hillman 1997, Pierce and Podner 2000). Adults over-winter in the restricted areas of the Blackfoot River near the Landers Fork confluence (Swanberg and Burns 1997).

Unlike the lower river bull trout population, this upper population 1) remains at low densities, 2) has not responded to protective angling regulations initiated in 1990, and 3) shows no signs of further recovery. According to long-term residents of the upper Blackfoot Valley, this bull trout population was once abundant.

Instream wood is a crucial and well-documented component to bull trout habitat in alluviated (C-type) channels. A 1996 telemetry study of this population found adult bull trout used woody debris as cover in 67\% of telemetry observations (Swanberg and Burns 1997). Other Blackfoot watershed bull trout studies confirm not only the importance of wood as bull trout cover in C-type channels (Swanberg 1997), but also the ability of bull trout numbers to improve in C-type channels following the addition of large instream wood (Pierce and Podner 2000). In addition to instream wood, Hillman and Chapman (1997), found bull trout in this river reach selected for scour pools and turbulent fast-water habitats. 
The riparian area of the Blackfoot River between the Landers Fork and Lincoln was surveyed and rated healthy in 1999 (Marler and Schmetterling 1999). Nevertheless, recent studies characterize the upper Blackfoot River upstream of Lincoln and Landers Fork as unstable, aggraded with habitat limitations (Chapman and Hillman 1997).

Rather than riparian health, habitat limitations seem related to a combination of historical channel alterations, channel scouring during major floods and the subsequent loss of instream wood. Portions of the Landers Fork were subject to historical riparian timber harvest activities. Both the Landers Fork and Blackfoot River upstream of Lincoln were also manipulated for flood
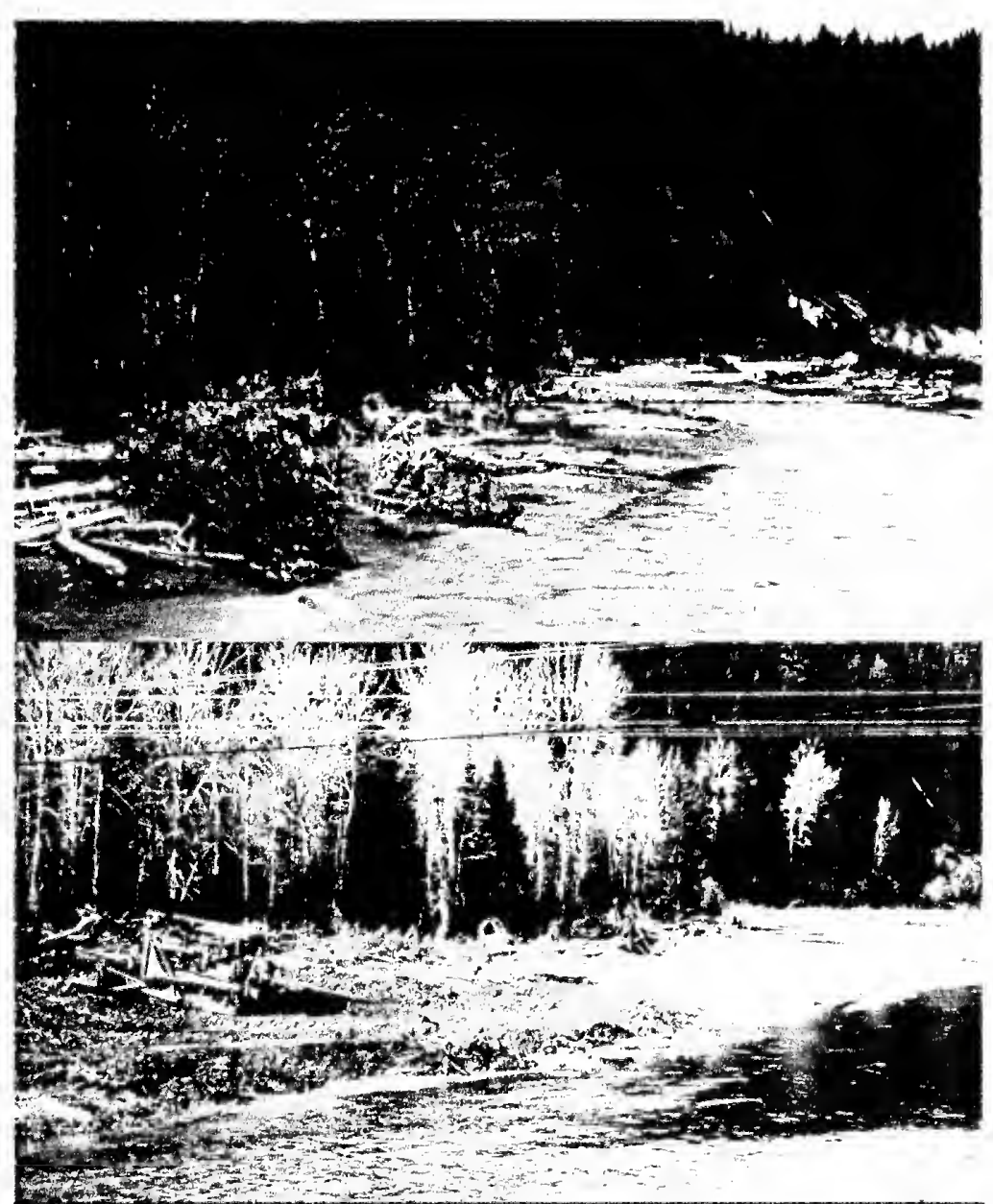

Figure 75. Before (06-02-72) and during (11-12-72) photos of a woody debris removal project on the Landers Fork upstream of highways 200 .

control through government-sponsored instream wood removal programs in $1960 \mathrm{~s}$ and $1970 \mathrm{~s}$. Alterations included instream channel clearing using of heavy machinery from Lincoln to the Landers Fork (Ed Grentier personal communication). In 1972, FWP documented similar channel cleansing activities in the Landers Fork (Figure 75). In 2000 , we observed additional adverse channel alterations in an aggraided channel upstream of an undersized bridge over the Blackfoot River upstream of Lincoln.

Sections of the Landers Fork and upper Blackfoot River annually flow subsurface during base flow periods. These intermittent reaches limit seasonal habitat availability and limit adult out-migrant bull trout to restricted areas of winter habitat (Swanberg and Burns 1997). The quality of these limited habitats has not been well quantified from a restoration perspective. 


\section{Survey Summary}

In fall 2000 , we conducted geomorphic and habitat surveys for: 1) a 6.3 mile section of the upper Blackfoot River (mile 109.8-116.1) downstream of the Landers Fork; and 2) the lower Landers Fork from the mouth upstream 7.2 miles (Figure 76). Surveys focused on measuring and classifying channel type (Rosgen 1996) and measuring pools and functional instream wood. Objectives were to 1) describe general trends in habitat condition, 2) identify broad limiting factors and 3) evaluate possible habitat restoration opportunities. During

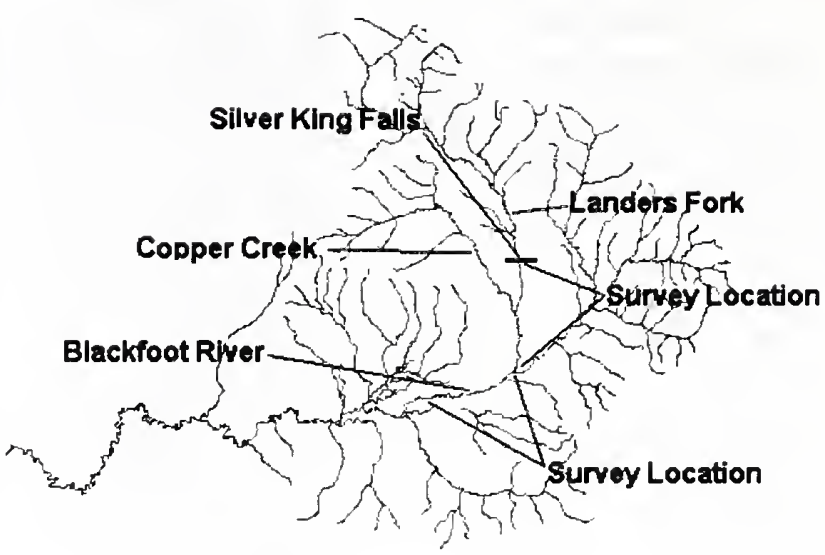

Figure 76. Habitat survey location map for the Landers Fork and upper Blackfoot River. summer 2000, we also electrofished an irrigation ditch from the Blackfoot River below the Landers Fork to evaluate possible ditch losses.

\section{Upper Blackfoot River: Lincoln to the Landers Fork}

We conducted the habitat survey for a 6.3-mile section of the Blackfoot River between Stemple Pass Road Bridge (mile 109.8) and the mouth of the Landers Fork (mile 116.1. We classified the channel as primarily a C4-type channel. Discharge was $27.9 \mathrm{cfs}$ below the Landers Fork on August 23, 2000. We timed our habitat survey (midOctober) corresponds with the known out-migration of bull trout from Copper Creek to wintering areas in the upper Blackfoot River (Swanberg and Burns 1997).

During our survey, the lower 3.9-miles of channel was intermittent, which prevented pool measurements. For the upper 2.4 miles of perennial stream, we counted all pools and measured parameters of every fourth pool. We also counted all functional instream wood, as well as wood within bankfull width.

We identified only 10 pools in the 2.4-mile perennial section; pool frequency was a low 0.79 pools/1000'. In the upper $1 / 3^{\text {rd }}$ of the perennial reach, pool frequency was 0.48 pools $/ 1000^{\prime}$

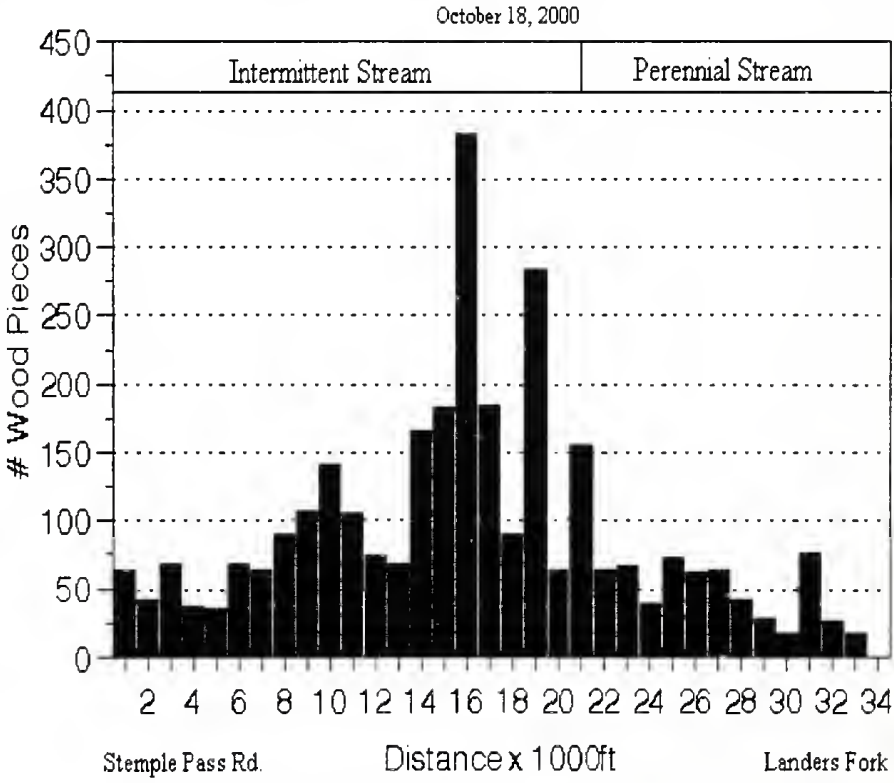

Figure 77. Instream woody debris (within the bankfull width) of Blackfoot River 2000. 
but increased to 0.96 pools $/ 1000^{\prime}$ in the lower $1 / 3^{\text {rd }}$, an increase of $100 \%$. Although pool frequency increased in the downstream direction, wetted pool width and maximum pool depth both decreased in the downstream direction. Mean wetted pool width was 22.7' in the upper half of the perennial section compared to $14.5^{\prime}$ in the lower section. Mean maximum pool depth was 2.5' (range 2.1-4.0') for entire perennial reach and ranged from $3.6^{\prime}$ in the upper half of the section compared to $1.9^{\prime}$ in the lower half. Instream wood providing cover in pools at base flows averaged 1.7 stems/pool with a mean size of 13 " $\mathrm{x}$ 35 '. We calculated pools at $3 \%$ of total wetted channel area.

For the perennial reach beginning at the junction of the Landers Fork, we recorded a trend of increasing instream wood in the downstream direction. For the upper $1 / 3^{\text {rd }}$ of the perennial reach, we counted 30.1 stems $/ 1000^{\prime}$ compared to 81.7 stems $/ 1000$ ' in the lower $1 / 3^{\text {rd }}$, an increase of $171 \%$. We found the highest wood concentrations (maximum $>350 \mathrm{stems} / 1000^{\prime}$ ) in a 1.3-mile section of intermittent channel (Figure 77). From the middle portion of the survey reach, we found a reverse trend of decreasing wood in the downstream direction, with concentrations of wood declining from $>200$ to $\sim 50$ stems $/ 1000$ ' in the gaining reach near Stemple Pass Road.

\section{Landers fork: Mouth to Silver King Falls}

We surveyed habitat for a section for a 7.25-mile stream reach extending from Silver King Falls downstream to the mouth (mile 116.1). We counted 37 pools in the survey section and measured 16 intensively. Although variable, we classified this stream section as primarily a B3c-type channel with a mean gradient of $1.4 \%$ (Rosgen 1996).

The habitat survey identified two reaches: 1) a 3.7-mile upstream reach extending from Silver King Falls (mile 7.25) to the mouth of Copper Creek (mile 3.55), and 2) a 3.6-mile downstream reach beginning at the mouth of Copper Creek extending downstream to the mouth of the Landers Fork. We found the upper channel to be stable, well-armored, and less

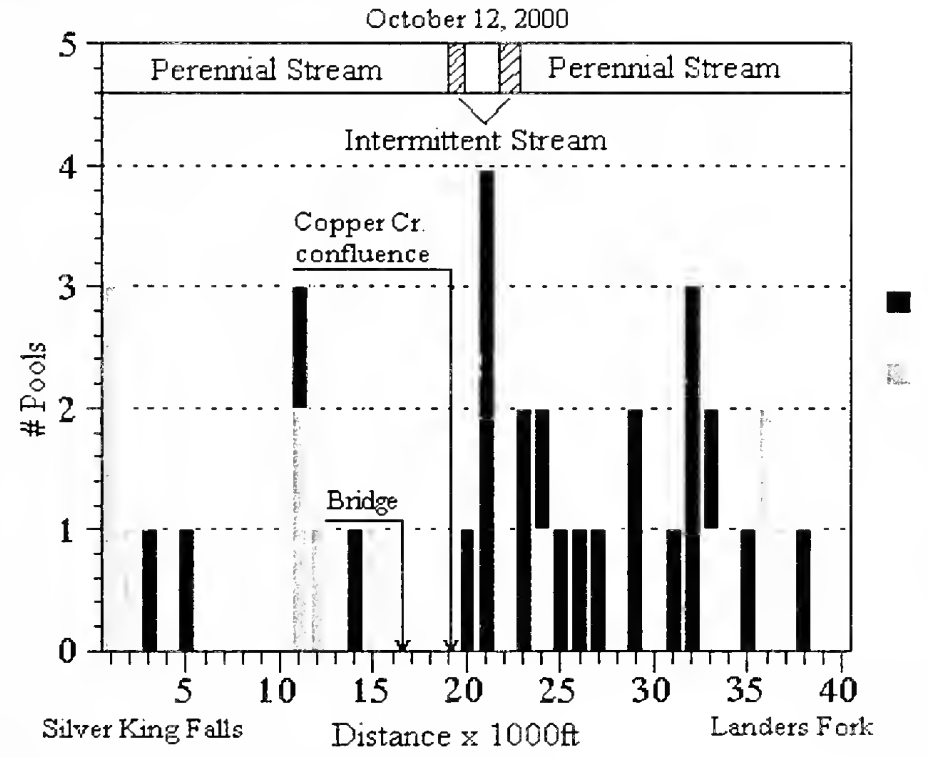

Figure 78. Distribution of pools with functional woody debris.

sinuous with lower habitat complexity than the downstream reach (Figure78). Based on historical aerial photos, riparian timber harvest was more intensive in this upper area than downstream reaches.

For the entire 7.25 -mile reach, we recorded pool frequency at 0.97 pools $/ 1000$ '. For the upper reach, mean pool frequency was 0.61 pools $/ 1000^{\prime}$ compared to 1.33 pools $/ 1000$ ' in lower reach-a $118 \%$ increase. 
Mean riffle length for the entire survey area was 988' (range 194-5,799') but varied between upper and lower reaches. The survey characterized large sections of the upper reach as continuous cobble-dominated channel with riffles averaging 1,568' (range 447-5,779') in length. Between mile 5.15 and 6.75, we counted only one pool in an 8,400 ' section. For the lower reach, riffles averaged 697' (range 194-1,508') in length. Near the mouth of Copper Creek (mile 4.35-3.15), the survey recorded a continuous riffle with only one pool in a 6,315' section.

Pools comprised 5\% of total stream area. Pools upstream of Copper Creek comprised $\sim 1 \%$ of total stream area, compared to $7 \%$ downstream of Copper Creek. Mean pool depth increased in the downstream direction from 2.2' (range 1.5-3.1) upstream of Copper Creek to 3.7' (range 1.7-5.5') downstream of Copper Creek.

Twenty-three of $37(62 \%)$ of pools contained large functional instream wood. Pools averaged 3.7 (range $0-15$ ) woody stems/pool. Only four of 12 pools $(33 \%)$ in the upper reach contained instream wood, compared to 20 of 25 pools $(80 \%)$ in the lower reach. Mean large woody stem size was 9'x 20.8 '.

We also identified two areas of intermittent flow in riffle dominated reaches: one upstream and one downstream of Copper Creek.

\section{Summary}

We assessed habitat features of pools and instream wood in portions of both the Landers Fork and the Blackfoot River. These streams provide rearing, over-wintering areas and migration corridors for a small population of fluvial bull trout. Both pool habitat and instream wood are fundamental habitat features for bull trout in alluviated (C-type) channels. Sections of both channels were subjected to past woody debris channel clearing activities, channel modifications and riparian timber harvest in addition to major flood events in the 1960s and 1970s.

For the upper 4.1 miles of the Landers Fork (mile 3.15-7.25), the lack of large instream wood has reduced pool frequency and complexity. In 1999, this section supported very low densities of juvenile bull trout ranging from 0.4-0.5 fish/100' in 1999 (Pierce and Podner). Below Silver King Falls, the Landers Fork once supported concentrations of adult bull trout use according to historical accounts (FWP files). Downstream of Copper Creek habitat complexity and pool quality increase. Channel stability appears to be improving in this area with early-successional woody species now establishing in areas of past channel disturbance.

The upper Blackfoot River downstream of the Landers Fork also lacks instream wood and pool complexity in the area of perennial flow. In the upper portion of the perennial reach, pools are deeper but less frequent and less complex. In the downstream direction, however both complexity and frequency increase in areas of declining flows. Further down stream into the intermittent reach, complex scour holes with large amounts instream wood become increasingly abundant.

The relationship of increasing habitat complexity in the downstream direction, probably influences bull trout in at least two ways. First, habitat simplification as a limiting-factor would contribute to reduced bull trout use and numbers in the upper perennial reach, and possibly displace bull trout to areas of more complex habitat. Secondly, high concentrations of instream wood in lower reaches would likely attract bull trout and other species to those locations during higher flow periods. 
According to the USFS fisheries biologist, by September of every year as flows decline and intermittent channels extends up-and downstream, an unknown segment of the bull trout population and five additional fish species are trapped in intermittent scour holes formed of large woody debris (Laura Burns, personal communication). Several "rescue" efforts have been undertaken in both the losing and gaining sections of the intermittent reach of the Blackfoot River. Because of public concern over fish kills, an annual rescue program is being considered by the USFS to reduce these losses in the intermittent reach. Fish losses however appear symptomatic of a larger problem that includes loss of habitat complexity in upstream perennial reaches. This habitat loss affects bull trout at multiple life-stages.

Habitat problems partly relate to past riparian timber harvest, channel alterations undertaken throughout the upper Blackfoot River and Landers Fork beginning in the 1960 s, channel scouring during major floods and the loss of instream wood. During our surveys, we found additional channel alterations caused by recent heavy equipment in the channel of the Blackfoot River upstream of Lincoln.

A history of adverse channel modifications, combined with current habitat limitations, suggest that restoring habitat complexity may be appropriate and beneficial to bull trout recovery. Restoration may or may not moderate direct fish losses in intermittent reaches; however, restoration would likely address other limiting factors related to reduced habitat complexity in rearing, staging and over-wintering areas and foster population recovery. Restoration should also be considered sections of the Blackfoot River upstream of the Landers Fork in areas of past channel alterations and/or low habitat complexity. A restoration pilot project, which includes population monitoring, would easily test the potential benefits of restoring wood to channels with low habitat complexity.

Our 2000 electrofishing survey results for an irrigation ditch near the lower portion of the perennial section were inconclusive for bull trout. We found no bull trout but did find entrained juvenile WSCT.

\section{North Fork Blackfoot River Riparian Inventories}

By M. Marler

In order to prioritize project sites and work effectively with landowners in the area, agencies need an assessment of riparian health and discussion of current problems. This inventory prepared at the request of Montana Fish, Wildlife and Parks (FWP) and the Bureau of Land Management in order to identify existing problems on the North Fork of the Blackfoot River.

The North Fork of the Blackfoot River is an important spawning tributary for bull trout (Salvelinus confluentus) and westslope cutthroat trout (Oncorhynchus clarki lewisi; Pierce and Schmetterling 1999), both species of special concern in Montana. Health of this river benefits not only resident fish, but also migratory populations of these species throughout the Blackfoot River drainage.

\section{Project Area}

This riparian inventory and health assessment covers private land along 9.6 miles of the North Fork of the Blackfoot River from the U.S. Forest Service Lolo National 
Forest boundary to the confluence with the Blackfoot River. Most of land along this section is privately owned.

\section{Results}

\section{Vegetation}

The dominant riparian plant community was black cottonwood/spruce (Populus trichocarpa/Picea engelmanii), intermixed with block cottonwood/Ponderosa pine (Pinus ponderosa). Below the Highway 200 bridge, black cottonwood intermixed with Rocky Mountain juniper (Juniperus scopularum) was common. Patches of sandbar willow/dogwood communities (Salix exigua/Cornus stolonifera) were very common along the entire section. These are the same dominant plant communities that occur throughout the Blackfoot drainage (Marler and Schmetterling 1999).

Several species of noxious weeds were present. Spotted knapweed (Centaurea maculosa) and ox eye daisy (Chrysanthemum leucanthemum) were the most common, and were spread almost continuously along the study area. Canada thistle (Cirsium arvense) and musk thistle (Carduus nutans) were also common, occurring in small patches $(<1$ acre $)$ at many locations throughout the project area. Hound's tongue (Cynoglossum officinale) and yellow toadflax (Linaria vulgaris) were also present, but were more restricted in their distribution.

Hound's tongue and yellow toadflax should be prioritized for control since they are currently the least abundant, and thus have the best chance for eradication. They are also very difficult to control once established.

\section{Erosion}

Eroded banks were identified as either naturally occurring or anthropogenic (Figure 1 and 2). Many times it was unclear whether the erosion was natural or anthropogenic; in such situations it was classified as natural in order to be conservative (as in Marler 1998).

\section{Health ratings}

Most of the study section was healthy (Figures 1,2, and 3 Table 1). A portion upstream of the county bridge was unhealthy, due to high densities of noxious weeds, actively eroding banks, and lack of deep-rooted vegetation. A few sections were ranked as at risk. Eroding banks caused by grazing and roads near the stream were a common factor resulting in this ranking, as was the presence of noxious weeds.

A section of the river just downstream of the county bridge is extensively shallow and braided. This section rated as "healthy" due to the presence of healthy riparian vegetation and the type of streambanks (coarse gravels). However, a geomorphology expert should be consulted to determine whether the channel structure is natural and appropriate for the river at that point, or if it is undergoing adverse adjustments in response to some anthropogenic activities up- or downstream. This section was an anomaly on the North Fork; however I encountered a similar reach on the Blackfoot mainstem just downstream of the Landers Fork (Marler and Schmetterling 1999).

Table 1. Length of study area in each health rating category.

\begin{tabular}{|l|l|}
\hline Health rating & Length of river (\%) \\
\hline
\end{tabular}




\begin{tabular}{|l|l|}
\hline Healthy & 6.6 miles $(69 \%)$ \\
\hline At risk & 2.4 miles $(24 \%)$ \\
\hline Unhealthy & 0.6 miles $(7 \%)$ \\
\hline
\end{tabular}

\section{Summary}

Most of the project area was healthy. Noxious weeds and streambank erosion were the primary factors contributing to lower health ratings.

Noxious weed control should be the highest priority for agencies and landowners involved with this area. The presence of noxious weeds in riparian areas is problematic because they can eliminate native species that provide essential ecological functions for the stream. These include binding soil to prevent erosion, providing shade to moderate stream temperatures, providing organic detritus to the aquatic food web, and woody debris for aquatic habitat (Hansen et al. 1995). As noxious weeds increase on a site, recruitment of native shrubs can be suppressed, overall botanical diversity decreases and the functions described above will eventually be lost (Olsen 1999). The species that are least widespread in the area (common toadflax and hound's tongue) should be prioritized for control (Sheley et al. 1999). If they have not already done so, landowners in the study section are encouraged to contact the Powell County Weed District to participate in a cooperative weed management area for planning and financial assistance. Funding is available to landowners for weed control from the Montana State Noxious Weed Trust Fund.

This mapping project will allow FWP and other agencies to identify problem areas on the North Fork of the Blackfoot River, and to work with private landowners to address these problems. 


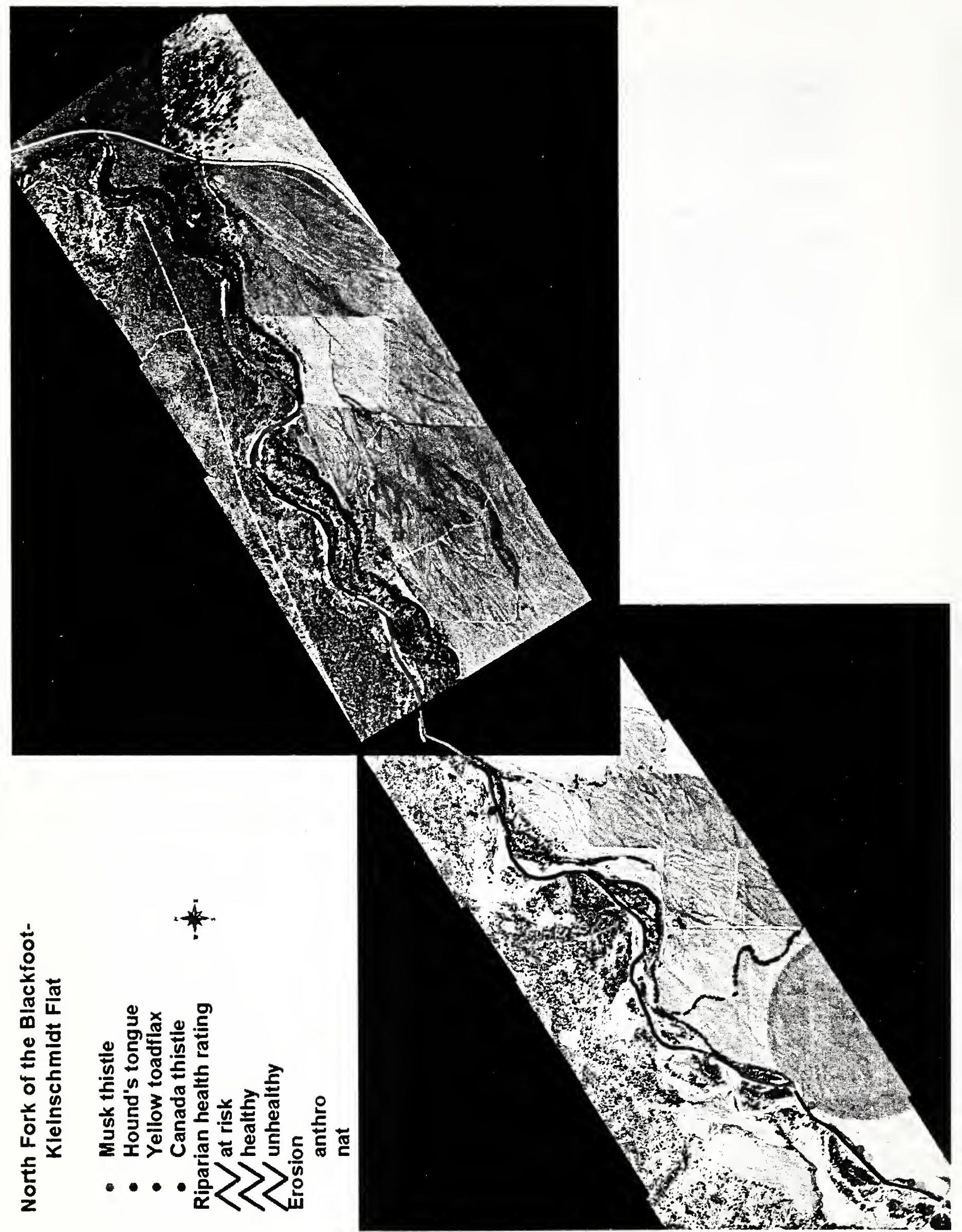




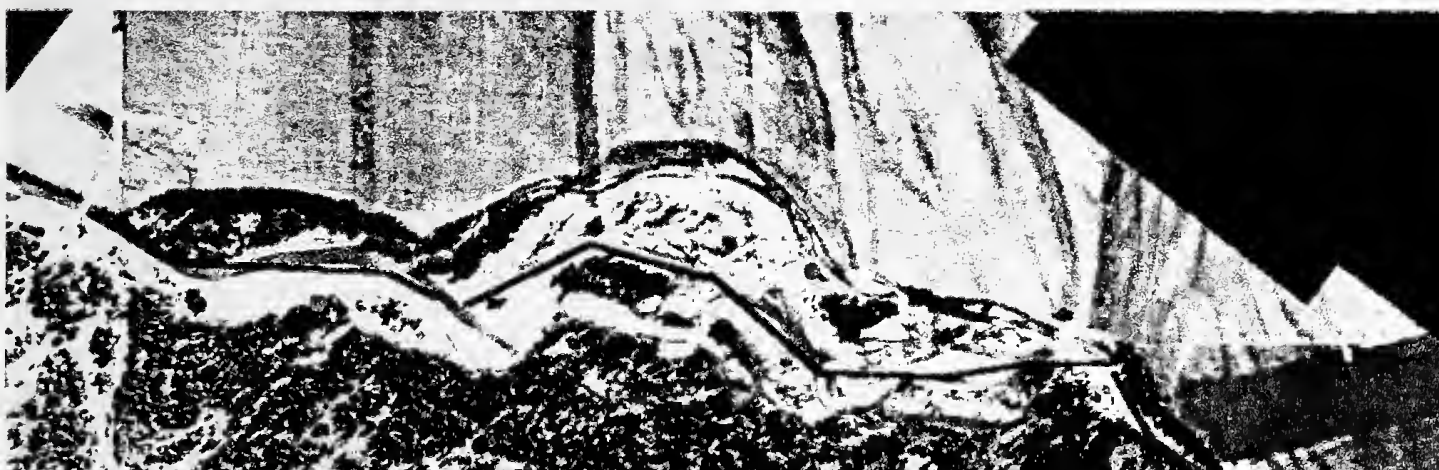

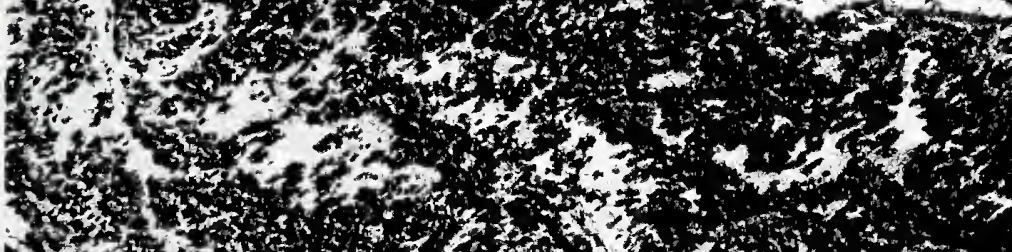

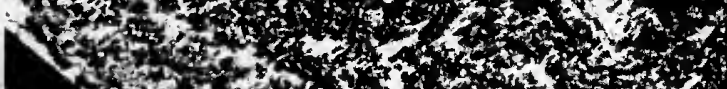
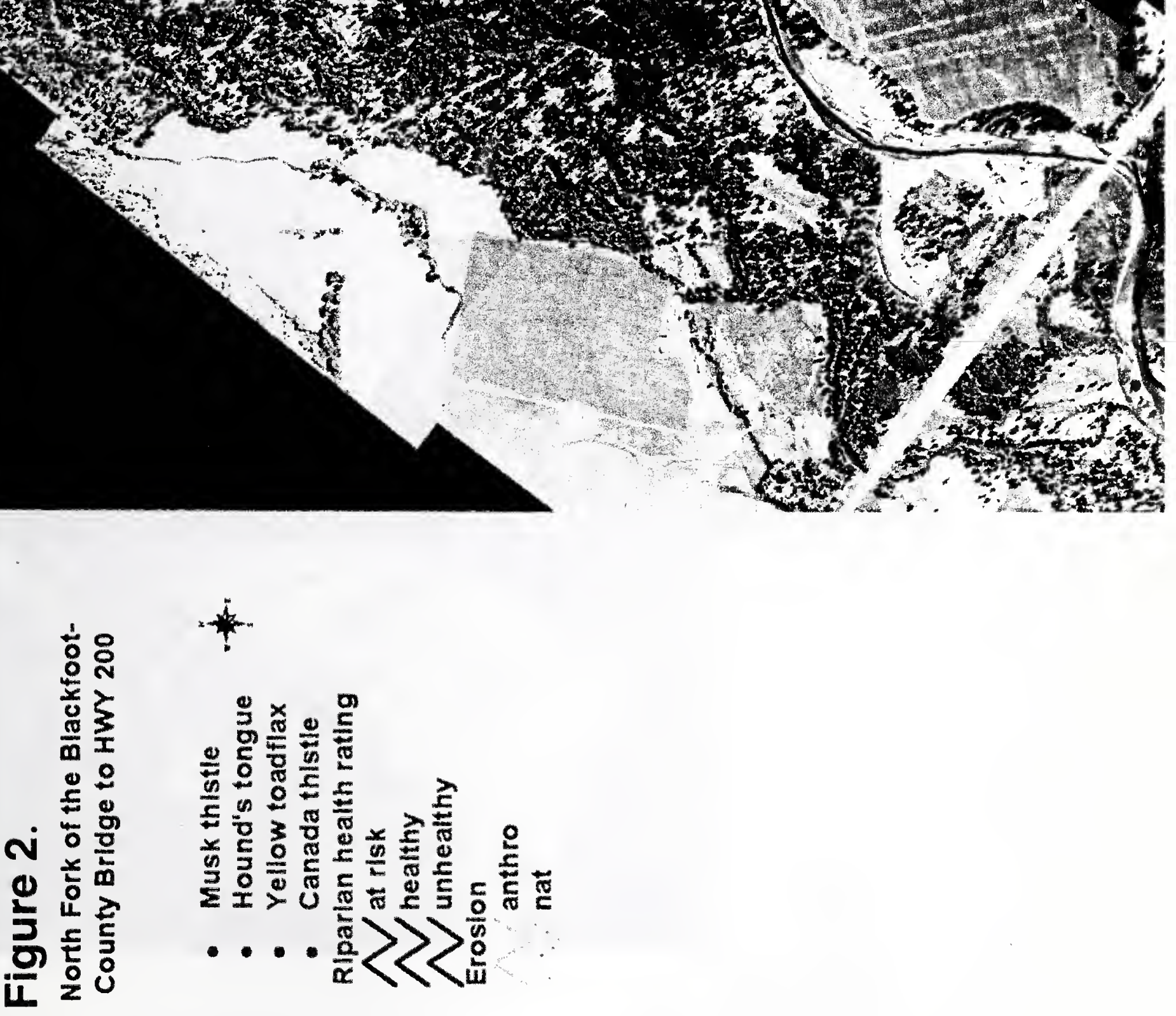


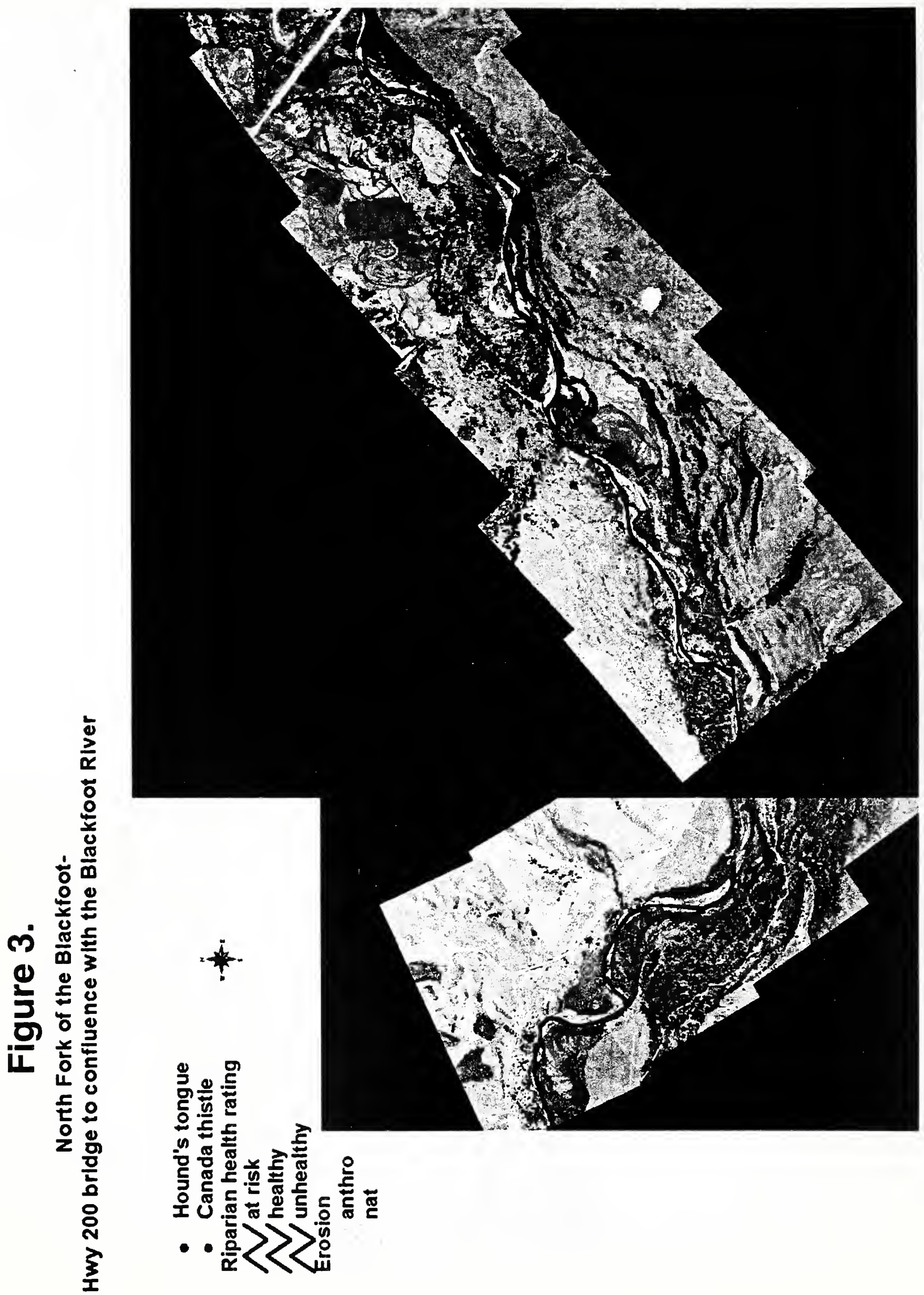




\section{Conclusions}

The Blackfoot River Restoration Program is largely a private land fisheries initiative, focusing on the recovery of native fish species. This initiative relies on the ability of agencies, watershed groups and landowners to meet multiple resource objectives. As such, this voluntary and cooperative initiative has gained broad support among landowners, land managers and the general public. Fish population monitoring continues to show positive gains in restoration streams. These gains include increased WSCT and bull trout densities in the lower Blackfoot River. Several project tributaries to the lower Blackfoot River (Johnson, Bear, East and West Twin, Belmont, Gold, sections of Cottonwood and Shanley, Chamberlain and Pearson, sections of Monture, Dunham and McCabe, sections of the North Fork, Rock and Kleinschmidt, and Grentier creeks) are complete or approaching latter phases of restoration.

Although restoration completion on project streams remains a priority, over the past two years, we have completed baseline and related special studies necessary to expand the program. Fisheries investigations indicate several streams (Poorman, Sauerkraut, Beaver, lower Willow, McElwain, Nevada, Nevada Spring, Yourname and Elk Creeks) have excellent restoration opportunities; all have potential to directly benefit Blackfoot River fish populations. Furthermore, populations of WSCT have basin-wide potential for significant improvement by incorporating riparian land management practices more sensitive to ecosystem health, particularly along the foothills of the Garnet Mountains.

Improving ecosystem health, incorporating proven yet practical restoration methods and operating within the socio-economic context of traditional Blackfoot Valley land-use, remains key to successful long-term native fish conservation. By working jointly with the agricultural community and other land managers, and by focusing on identified limiting factors, tributary populations and the resiliency of river populations should continue to improve despite cycles of low flow, river warming, wildfire, ice flows and other environmental disturbance.

In addition to expanding the restoration initiative, emerging challenges to wild trout conservation further include: 1) the recent introduction of several exotic and invasive aquatic species; 2) the remediation of Milltown Dam impacts to Blackfoot River fish populations; and 3) upward trends in recreational river use in critical native trout recovery areas. The long-term conservation of native fish requires commitment to these emerging issues, some of which present formidable challenges. 


\section{Program Recommendations}

- Continue the effort by the Montana Fish, Wildlife and Parks and UFWS Partners of Fish and Wildlife Program on the Blackfoot Restoration Project. This effort relies on personnel with primary responsibilities of coordinating restoration and land management changes that are sensitive the fish and wildlife. This effort further requires increased fisheries personnel to cover basic fieldwork and other program needs. Support and additional efforts should be provided through watershed groups including the Big Blackfoot Chapter of Trout Unlimited, the North Powell Conservation District, the Blackfoot Challenge as well as other supporting agencies and organizations.

-Begin to shift program direction from inventory and problem identification to more restoration. Complete restoration projects in all core area and current restoration streams. Expand restoration as staff and funds become available.

-Continue fish populations monitoring at the Johnsrud and Scotty Brown Bridge section of the Blackfoot River, and tributary restoration projects.

-Address fish passage and northern pike issues at Milltown Dam and continue to mitigate for Milltown Dam within the geographic range of fish population impacts.

-Focus restoration and protection on migration corridors, spawning and rearing areas, and tributaries which have high proportion of their stream length in higher elevation and basin-fed stream with steeper gradients, which have been found to be less susceptible to $T$. tubifex and whirling disease.

-Continue to monitor the spread and impacts of whirling disease and the results of restoration on infection rates and incorporate pertinent results into the restoration program.

-Increase landscape protection efforts through conservation easements on critical fish and wildlife habitat in cooperation with the Montana Land Reliance, Nature Conservancy, US Fish and Wildlife Service and Montana Fish, Wildlife and Parks.

- The downward trend in the upper Blackfoot River westslope WSCT population underscores the need for a thorough and timely cleanup of the Mike Horse mine and associated public lands.

-Adopt a conservative approach to recreational planning in native fish recovery areas. These include the lower mainstem Blackfoot River below the confluence of the North Fork, Monture Creek and North Fork downstream of the North Fork Falls.

-Develop an effective fish identification program directed toward non-resident anglers.

-Investigate possible range expansion of brown trout. 


\section{Acknowledgements}

The Big Blackfoot Chapter of Trout Unlimited (BBCTU), U.S. Fish and Wildlife Service, Chutney Foundation, North Powell Conservation District, Montana Power Company and Bureau of Land Management made the 2000 fisheries program possible by funding two seasonal fisheries technicians. These technicians complete the Garnet Mountain data collections, assisted in project monitoring and made much of the restoration work possible. The Fish and Habitat Committee of the BBCTU reviewed and administered projects, resolved social conflicts, assisted in project maintenance and sponsored the Rosgen training sessions. This continued commitment of BBCTU is the key to long-term river restoration. The USFWS Partners for Fish and Wildlife Program continued to support of the native fish initiative. Dave Rosgen provided insight, training and helped develop our restoration methods. Regional FWP fisheries staff included contributions of David Schmetterling, Ladd Knotek, Mark Bohnemann and Brad Liermann. Glen Phillips and Mark Lere and the Future Fisheries Committee supported the effort though funding, administration and environmental permitting. Other key agency cooperators included: 1) the Natural Resources Conservation Service for their contributions in the Nevada Creek watershed; 2) the Bureau of Land Management for funding whirling disease and riparian inventory studies; 3 ) the U.S. Forest Service for their efforts on Dunham Creek; 4) the Montana Department of Transportation for funding the Kleinschmidt Creek project; 5) the Department of Natural Resources and Conservation for assisting in drought mitigation and for evaluating ditch efficiencies on Kleinschmidt Flat; and 6) the Bureau of Reclaimation for providing engineering assistance on several projects. Montana Power Company and Plum Creek Timber Company supported several restoration projects. We also thank the interns, high school teachers and students, consultants, contractors and all the landowners that cooperated on restoration projects and allowed us access to streams during the 2000 field season. Finally, the comments of David Schmetterling improved the quality of this report. 


\section{Literature Cited}

Allendorf, F. W., and R. F. Leary. 1988. Conservation and distribution of genetic variation in polytypic species, the cutthroat trout. Conservation Biology 2:170-184.

Cooksey, D. and R. Sheley. 1998. Mapping noxious weeds in Montana. Montana State University Extension Service Publication EB 148. Bozeman, Montana, USA.

Hansen, P., R. Pfister, K. Boggs, B. Cook, J. Joy, and D. Hinckley. 1995. Classification and management of Montana's riparian and wetland sites. Miscellaneous Publication 54, Montana Forest and Conservation Experiment Station, School of Forestry, The University of Montana, Missoula, Montana.

Hillman T. W. and D.W. Chapman. 1996. Assessment of fish populations in the upper Blackfoot River basin. A report to the Seven-up Pete Joint Venture. BioAnalysts Boise Idaho.

Fitzgerald, G. 1996. Inventory and analysis of riparian vegetation along lower Nevada Creek. A report to the Montana Fish, Wildlife and Parks, Missoula, Montana

Fitzgerald, G. 1997. Analysis and inventory of riparian vegetation along Nevada Creek and Monture Creek, using ADAR imagery. MS Thesis, University of Montana, Missoula, Montana.

Fredenberg, F. 1992. Evaluation of electrofishing -induced spinal injuries resulting from field electrofishing surveys in Montana. Montana Department of Fish, Wildlife and Parks, Bozeman, Montana

Kerans, B. L., M, M. Gangloff and E. R. Vincent. 1999. Spatial relations between whirling disease severity and tibuficids. Proceedings of the Fifth Anmual Whirling Disease Symposium, Research and Management Perspectives, Missoula, MT. Whirling Disease Foundation, Bozeman, Montana.

Ingman, G, L., M.A. Kerr and D.L. McGuire 1990. Water quality investigations in the Blackfoot River drainage, Montana. Department of Health and Environmental Services, Helena, Montana.

Liknes, G. A. 1984. The present status and distribution of the westslope cutthroat trout (Salmon Clarki lewisi) east and west of the continental divide in Montana. Report to the Montana Department of Fish, Wildlife and Parks, Helena, Montana.

Liknes, G. A. and P. J. Graham. 1998. Westslope cutthroat trout in Montana: life history, status and management. Pages 53-60 in R.E. Gresswell, editor. Status and management of westslope cutthroat trout: American Fisheries Society, Symposium 4, Bethesda, Maryland.

Marler, M. 1997. Riparian health and inventory of the Blackfoot River between Nevada Creek and the North Fork Confluence: A GIS mapping project. Report to Montana Fish, Wildlife and Parks, Missoula, MT. 
Marler, M. 2000. Distribution of leafy spurge (Euphorbia esula) along the Blackfoot River: River Junction to Corrick River Bend. Report to BLM Garner Resource Area, Missoula, MT.

Marler, M., and D. A. Schmetterling. 1999. Riparian health and inventory of selected reaches of the Blackfoot River. Final Report to the BLM Garnet Resource Area and Montana Fish, Wildlife and Parks, Missoula, MT.

MBTSG (Montana Bull trout Scientific Group). 1995. Blackfoot River drainage bull trout status report. Unpubl. Report prepared for the Montana Bull Trout Restoration Team. Montana Fish, Wildlife and Parks.

McGuire, D. 1989. Blackfoot River aquatic macroinvertebrate survey. Prepared for the Montana Water Quality Bureau and Oakbrook Chapter of Trout Unlimited.

McGuire, D. 1991. Aquatic macroinvertebrate survey of the Blackfoot River, Montana, August, 1988 and 1989. Prepared for the Montana Department of Health and Environmental Sciences Water Quality Bureau, Helena, Montana.

McIntyre, J. D., and B. E. Reiman, 1995. Westslope WSCT. Pages 1-15 in M. K. Young, editor. Conservation assessment for inland WSCT. U. S. Forest Service General Technical Report. RM-256.

Montana Fish, Wildlife and Parks. 1989, 1991, 1993, 1995, 1997, 1999. Statewide fishing pressure estimates. Bozeman, Montana.

Montana Fish, Wildlife and Parks. 1999. Statewide angler satisfaction surveys. Bozeman, Montana.

Montana Fish, Wildlife and Parks. 2000. Unpublished fisheries and recreational conflict data.

Montana Bull Trout Restoration Team. 2000. Restoration plan for bull trout in the Clark Fork River Basin and Kootenai River Basin Montana. A report to Governor Marc Racicot c/o Montana Fish, Wildlife and Parks, Helena, Montana.

Olsen, B. 1999. Impacts of noxious weeds on ecologic and economic systems. Pages4-18 in R. Sheley and J. Petroff, eds. Biology and Management of Noxious Rangeland Weeds. Oregon State University Press, Corvallis, OR.

Peters, D. 1985. Current status of bull trout in the headwaters of the Clark Fork River, Montana. Page 37 in D. D. MacDonald, editor, Proceedings of the Flathead River basin bull trout biology and population dynamics modeling Information exchange Fisheries Branch, Brithish Columbia Ministry of Environmental. Cranbrook, British Columbia.

Peters, D. and R. Spoon. 1989. Preliminary fisheries inventory of the Big Blackfoot River. Montana Department of Fish, Wildlife and Parks, Missoula, Montana.

Peters, D. 1990. Inventory of fishery resources in the Blackfoot River and major tributaries to the Blackfoot River. Montana Department of Fish, Wildlife and Parks, Missoula, Montana.

Pierce R. and D. Peters, 1990. Aquatic investigations in the middle Blackfoot River, Nevada Creek and Nevada Spring Creek corridors. Montana Department of Fish, Wildlife and 
Parks, Missoula.

Pierce, R, 1991. A stream habitat and fisheries analysis for six tributaries to the Blackfoot River. Montana Department of Fish, Wildlife and Parks, Missoula, Montana.

Pierce, R., D. Peters and T. Swanberg. 1997. Blackfoot River restoration progress report. Montana Fish Wildlife and Parks, Missoula, Montana.

Pierce, R., and D. Schmetterling. 1999. Blackfoot River restoration project monitoring and progress report 1997-1998. Montana Fish, Wildife and Parks, Missoula, Montana.

Pierce, R. and C. Podner. 2000. Blackfoot River fisheries, inventory, monitoring and restoration report. Montana Fish, Wildlife and Parks, Missoula, Montana.

Ricker, W.E. 1975. Computation and interpretation of biological statistics of fish populations. Bulletin of the Fisheries Research Board of Canada, Bulletin 191. Ottawa Canada.

Rosgen, D. 1996. Applied Fluvial Geomorphology. Wildland Hydrology, Pagosa Springs Colorado.

Schmetterling D. and M. Long. 1999. Montana anglers inability to identify bull trout and other salmonids. Fisheries Vol. 24 No. 7, pp. 24-27.

Schmetterling D. A, and R. W. Pierce. 1999. Success of instream habitat structures after a 50year flood in Gold Creek, Montana. Restoration Ecology 7(4), pp. 369-375.

Schmetterling, D. A. 2001. Seasonal movement of westslope cutthroat trout in the Blackfoot drainage, Montana. North American Journal of Fisheries Management, in press.

Schmetterling, D. A. and M. J. Bohnemann. 2001. The 1999 Blackfoot River creel survey. Montana Fish, Wildlife and Parks, Missoula, Montana.

Schmetterling, D. A. and B. W. Lieremann. 2000. Milltown Dam fish trapping and transport 2000. Final report to Montana Power Company and the Bureau of Land Management, Missoula Field Office.

Schmetterling, D. A., R. W. Pierce and B. W. Lieremann. In-prep. Efficacy of three Denil fish ladders for low flow fish passage in two tributaries to the Blackfoot River.

Sheley, R., S. Kedzie-Webb, and B. Maxwell. 1999. Integrated weed management on rangeland. Pages 57-68 in R. Sheley and J. Petroff, eds. Biology and Management of Noxious Rangeland Weeds. Oregon State University Press, Corvallis, OR.

Shepard, B. B., B. Sanborn, L. Ulmer, and D.C. Lee. 1997. Status and risk of extinction for westslope cutthroat trout in the upper Missouri River basin, Montana. North American Journal of Fisheries Management 17:1158-1172.

Smith. L., 1998. Study on the distribution and abundance of Tubifex tubifex within Cottonwood Creek in the Blackfoot Drainage. MS Thesis, University of Missoula, Missoula, Montana. 
Swanberg, T. R. 1997. Movements of and habitat use by fluvial bull trout in Blackfoot River. Transactions of the American Fisheries Society 126:735-746.

Swanberg, T. and L. Burns. 1997. Movement and habitat use of radioed tagged bull trout in the upper Blackfoot River drainage, Special report Region 2 Fisheries. Montana Fish, Wildlife and Parks, Missoula, Montana.

Thomas, G. 1992. Status report: bull trout in Montana. Unpubl. Report prepared for Montana Fish, Wildlife and Parks, Helena, Montana. 


\section{Appendix}

Exhibit A: Summary of catch and size statistics Blackfoot River tributaries, 2000.

Exhibit B: Summary of two pass population estimates for tributaries, 2000.

Exhibit C: Mark and recapture estimates in the Blackfoot River drainage, 2000.

Exhibit D: Summary of stream discharge measurements, 2000.

Exhibit E: Restoration stream and table of activities through 2000.

Exhibit F: Conceptual restoration process for private land.

Exhibit G: Table of potential restoration projects in the Blackfoot Drainage.

Exhibit H: Table of restoration streams and cooperators.

Exhibit I: Summary of water temperature monitoring in the Blackfoot Drainage, 2000.

Exhibit K: Westslope WSCT genetic sampling results. 


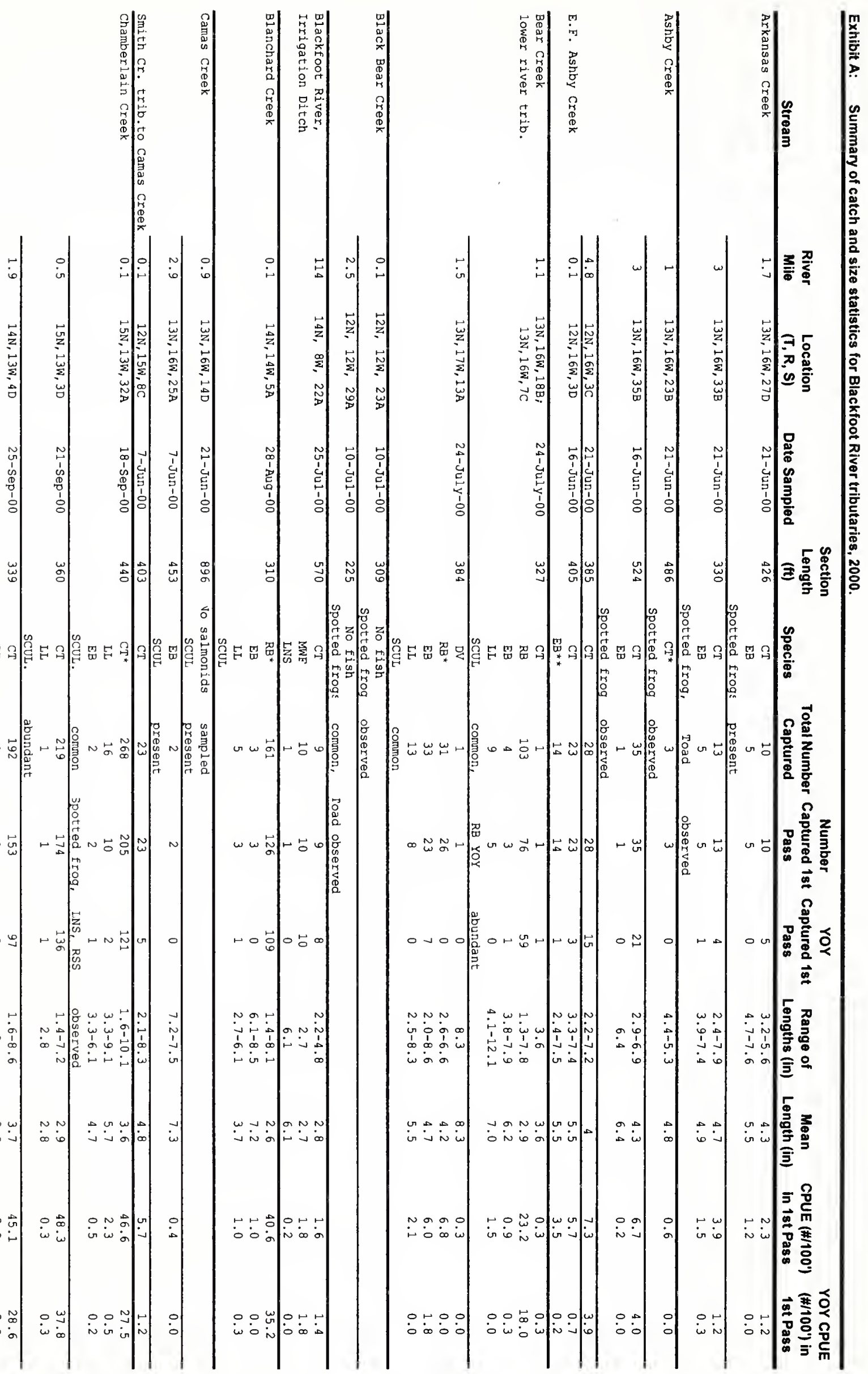




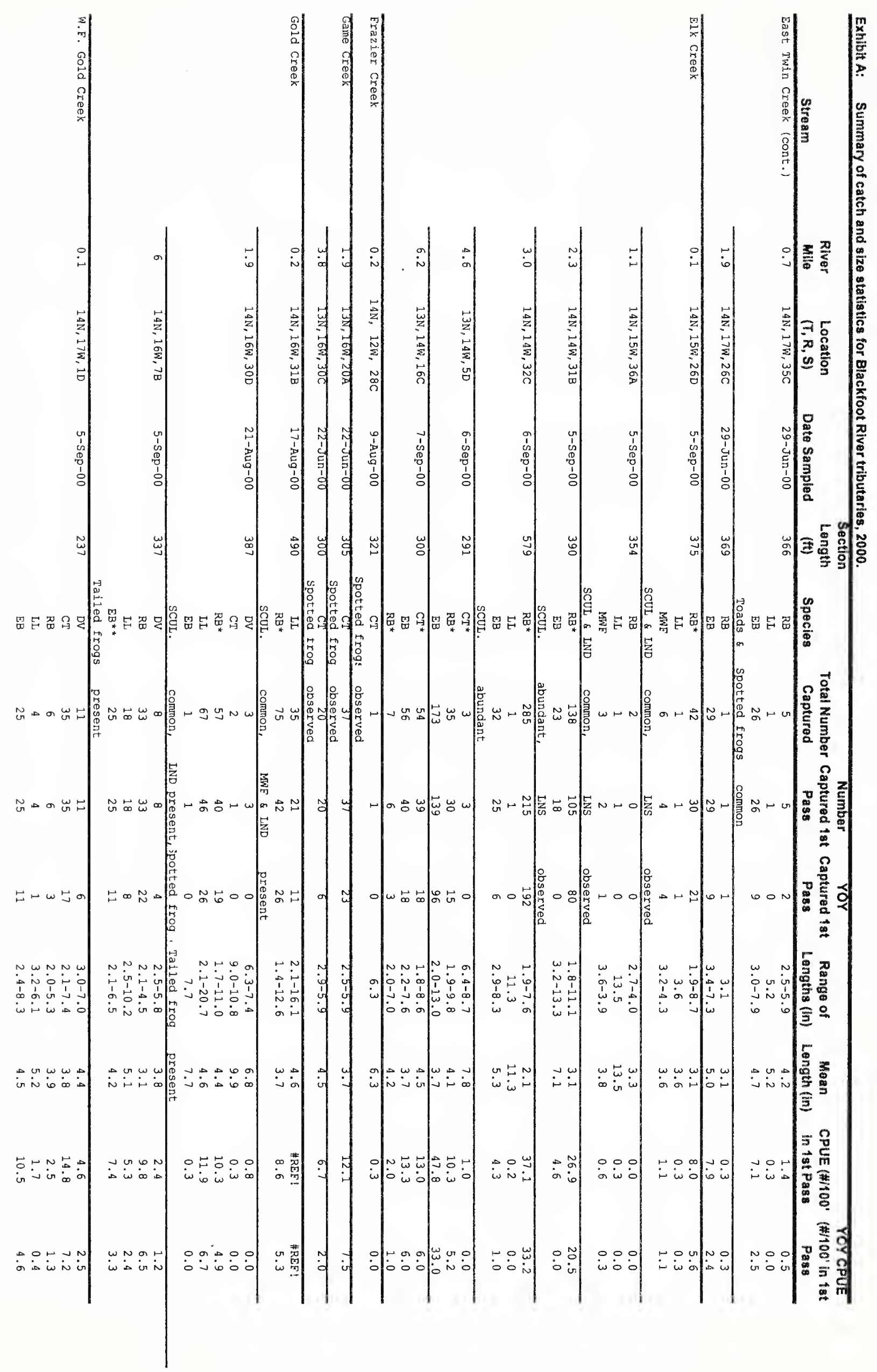




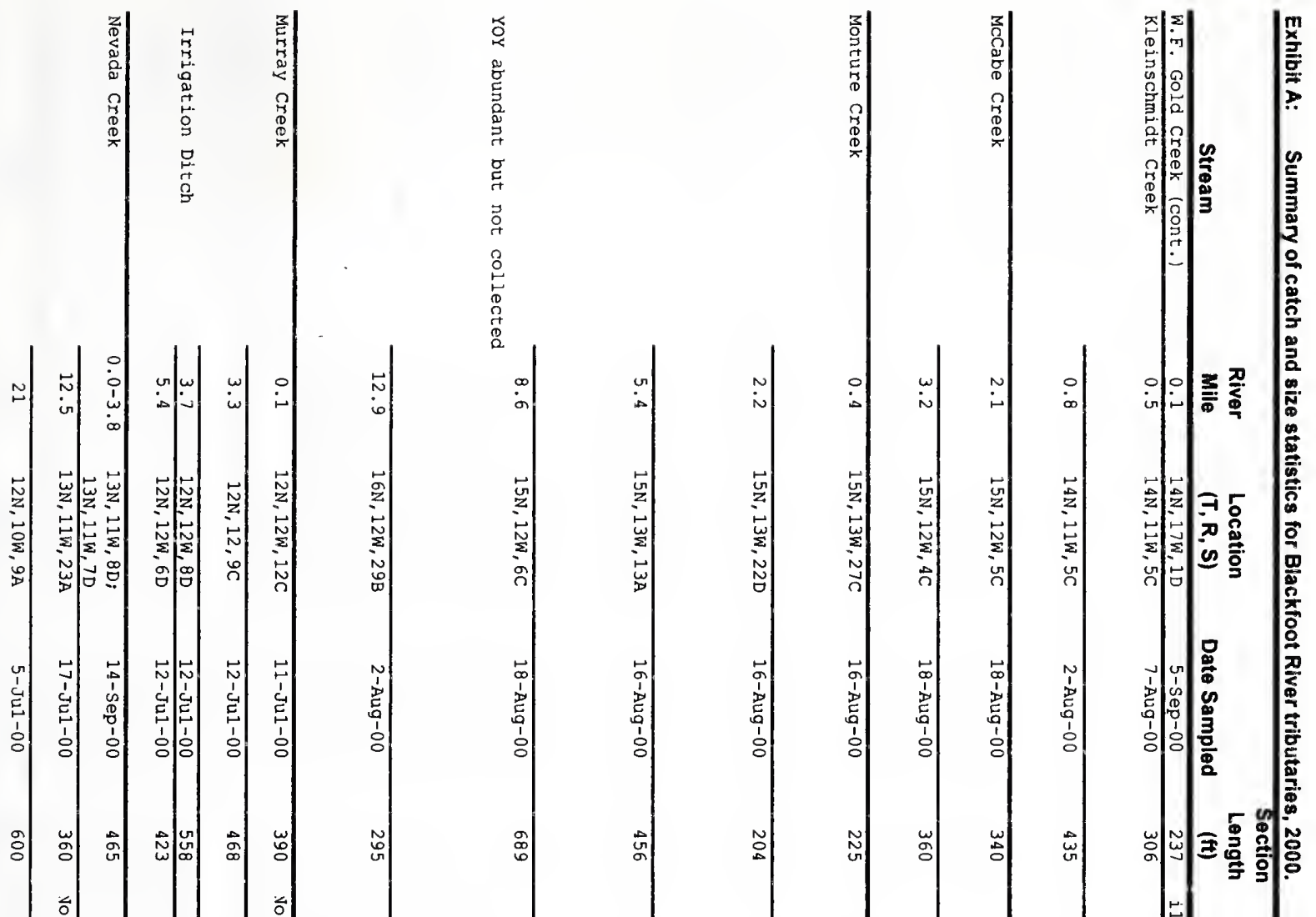

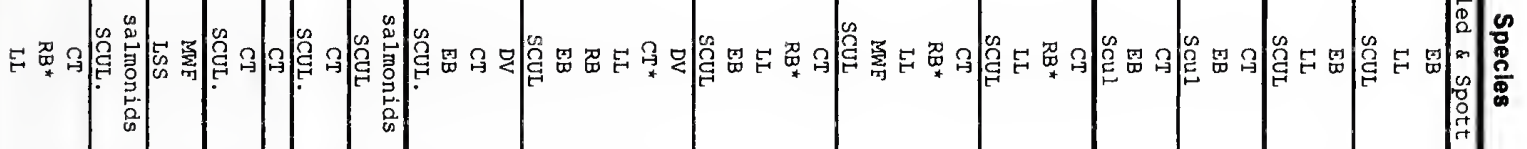

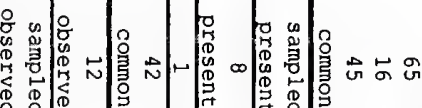

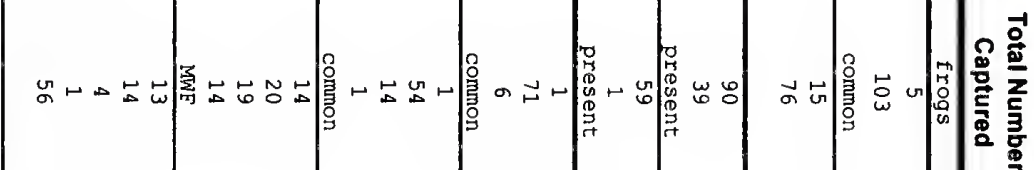

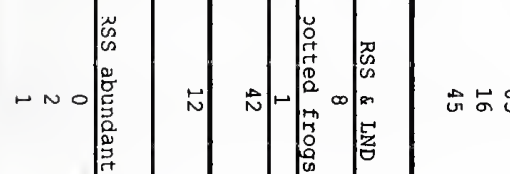

-

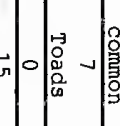

نे

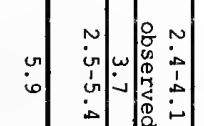

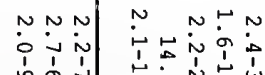

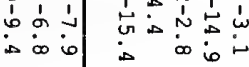

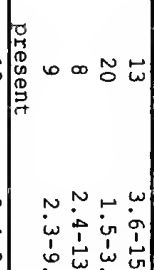

年

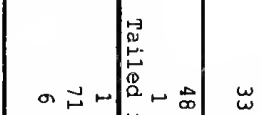

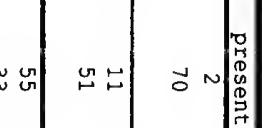

क्ष

$\rightarrow G$

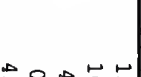

하나

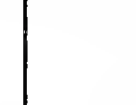

as is iv

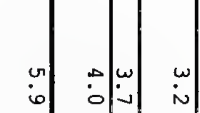

$\Delta \omega N$

ด.

$\rightarrow \operatorname{man} \omega \omega \div 0$

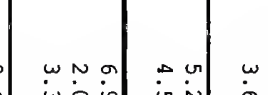

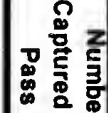

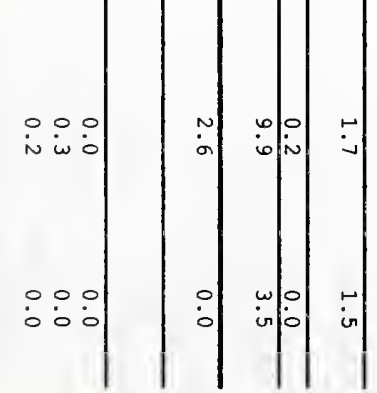
is

जั) (1) 


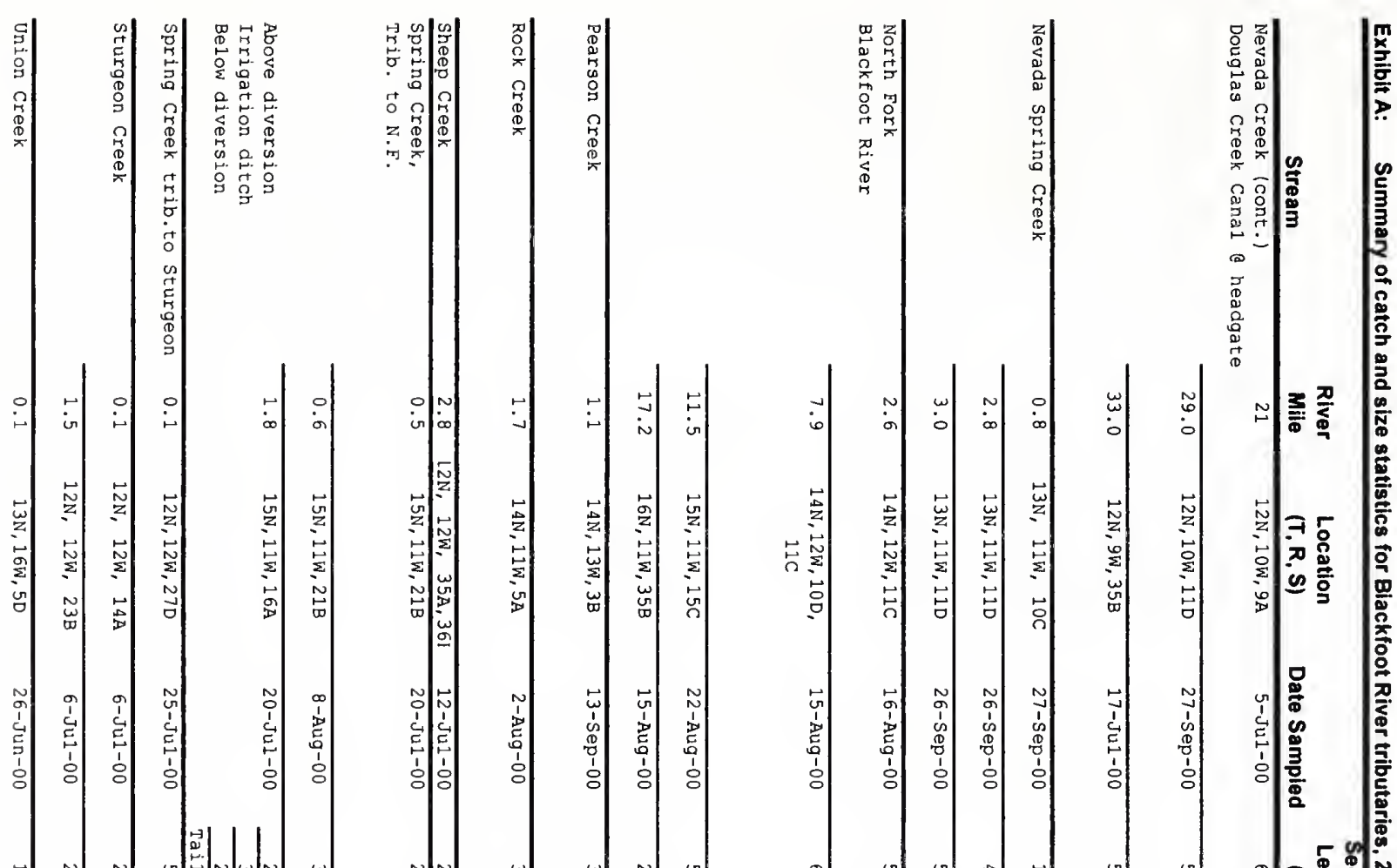

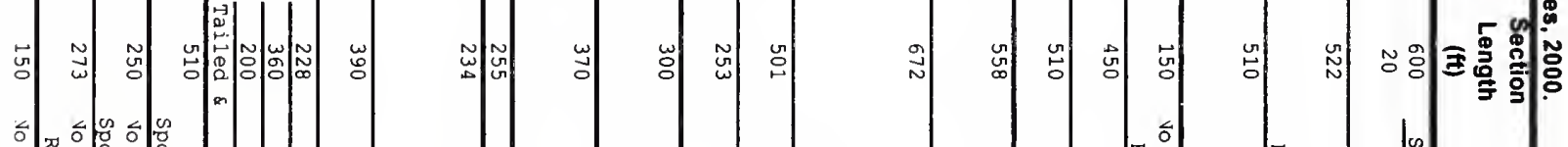

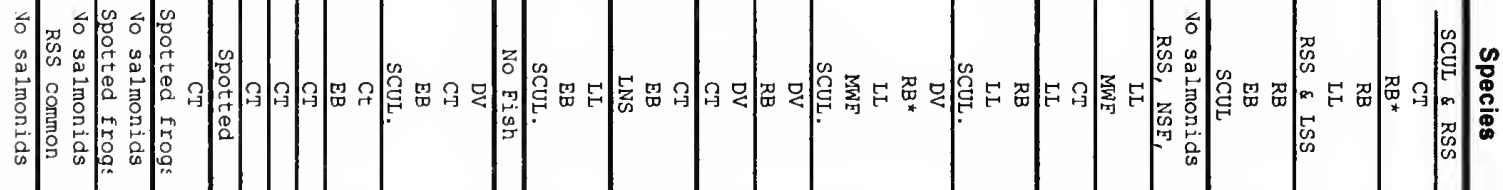

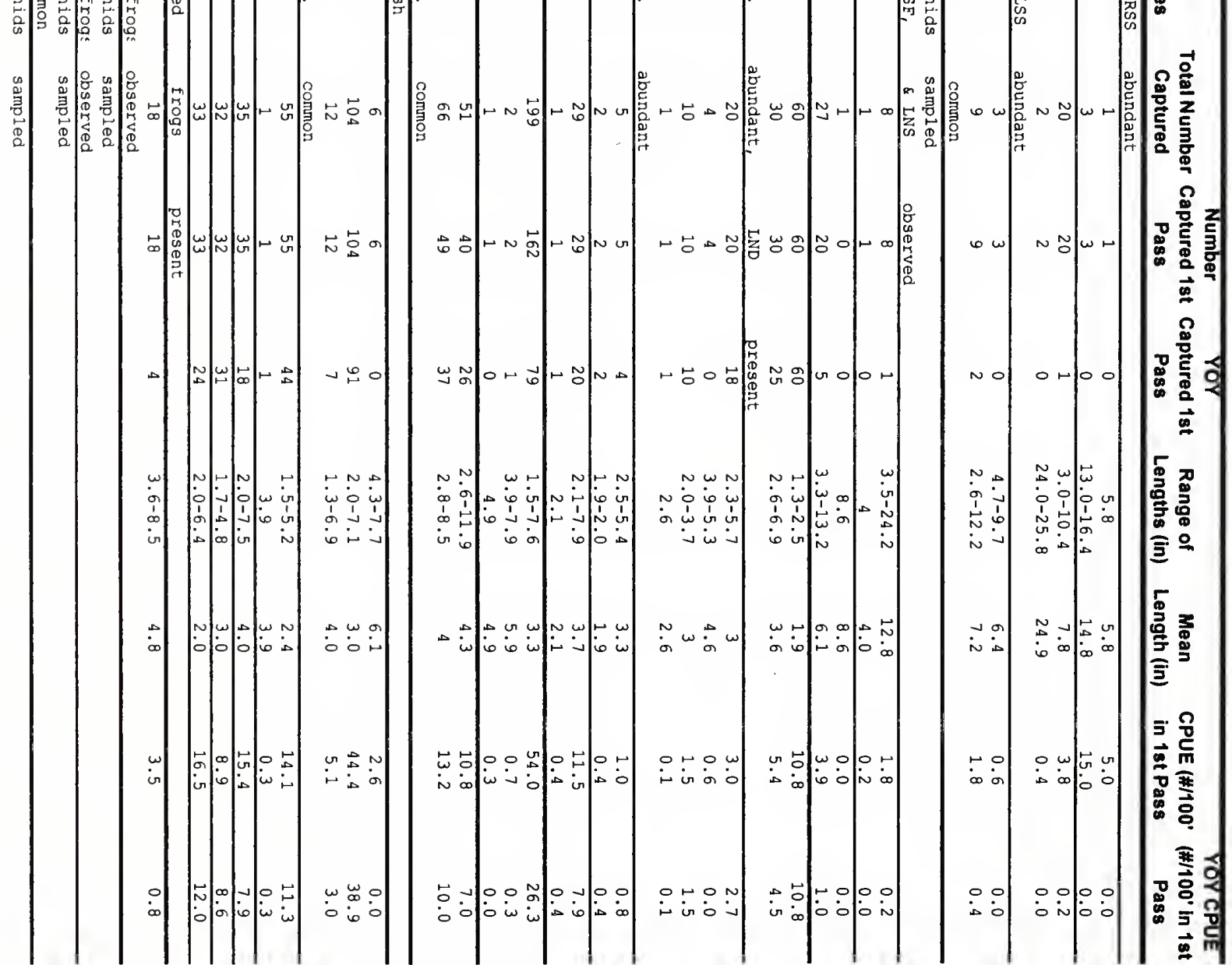




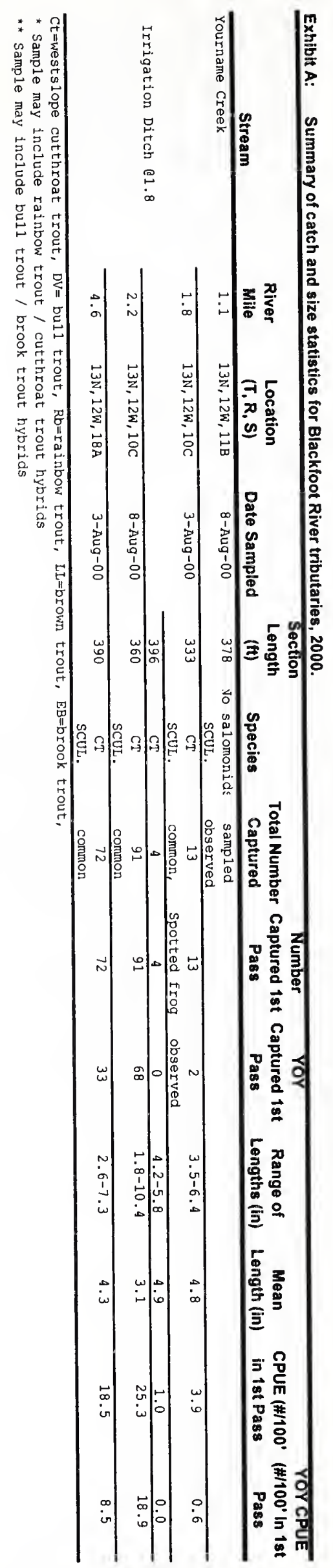




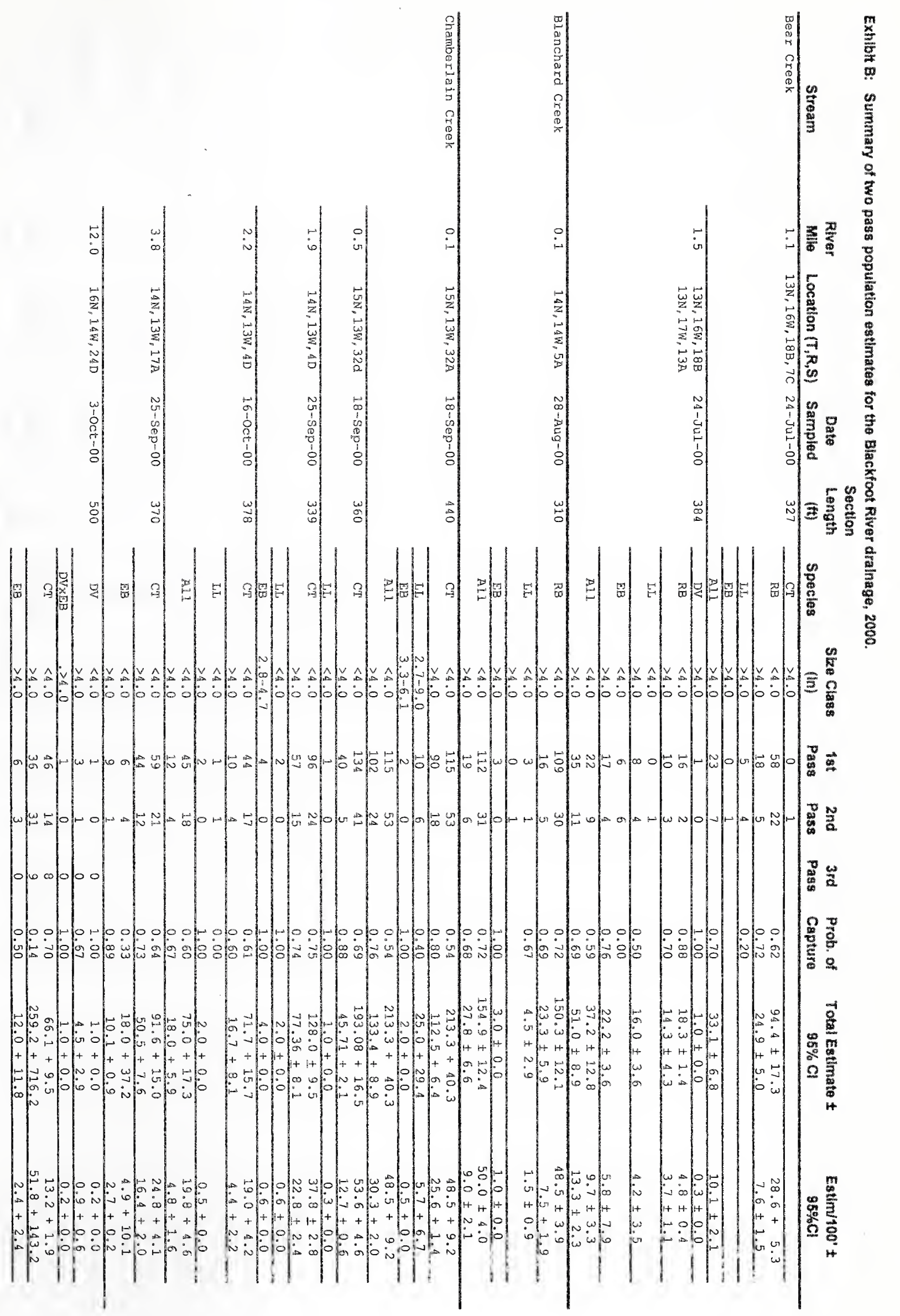




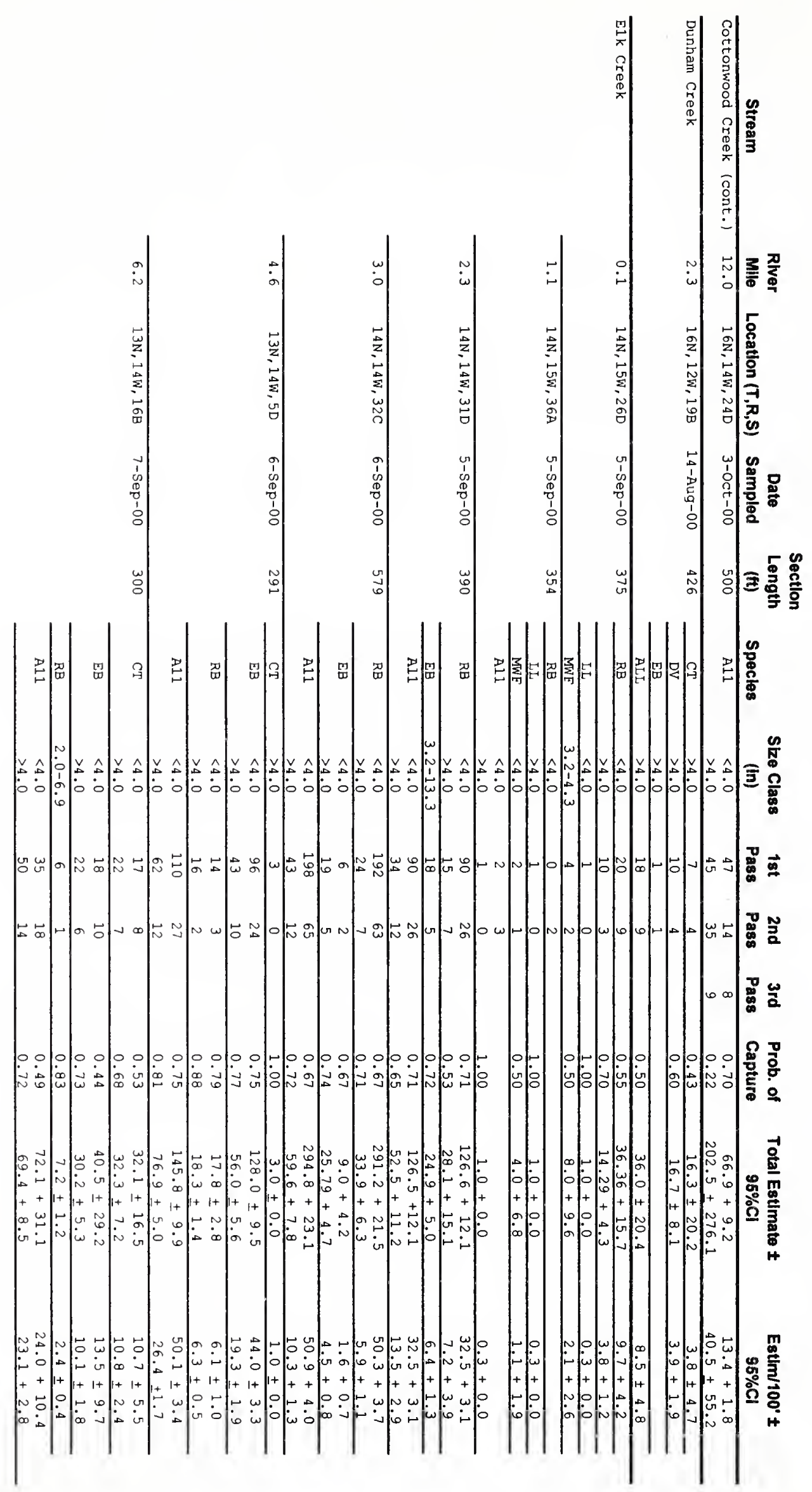




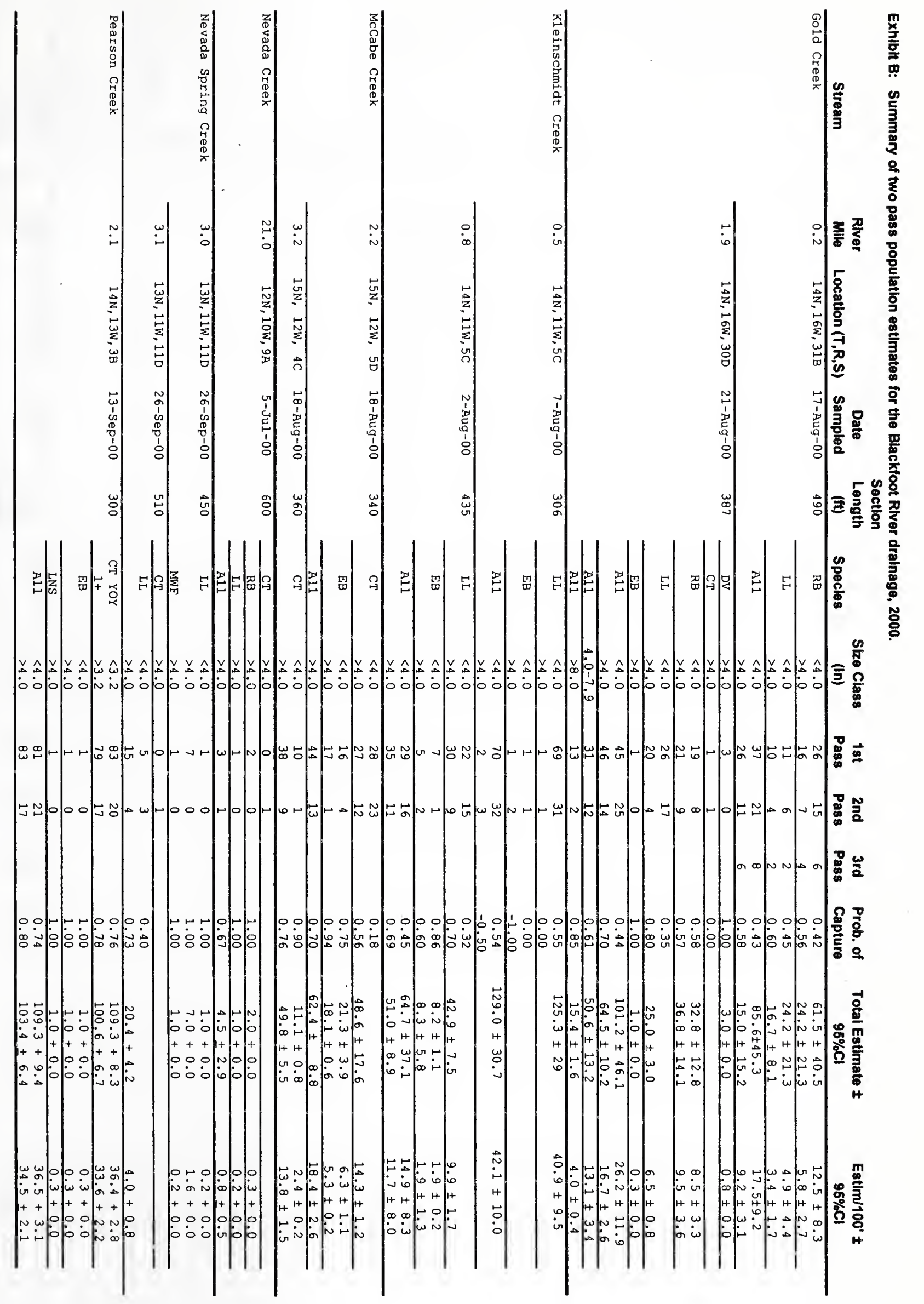




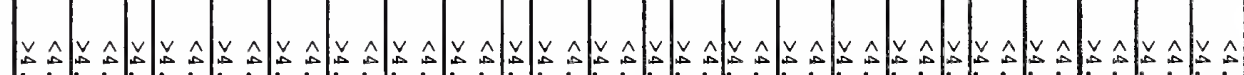
$\therefore 0$

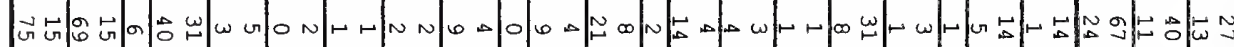

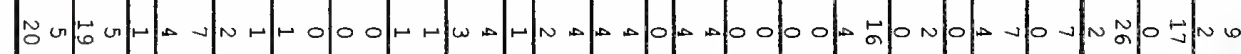

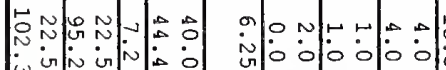

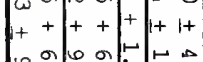

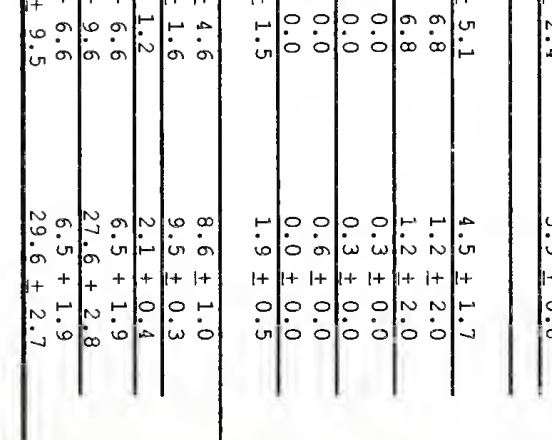
8 o

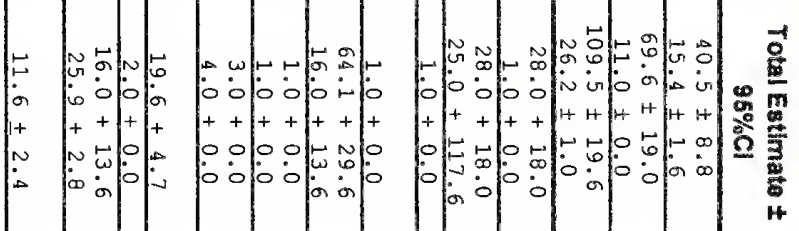

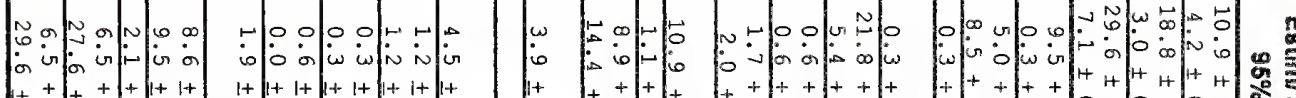

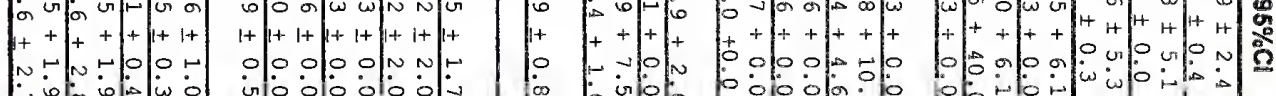

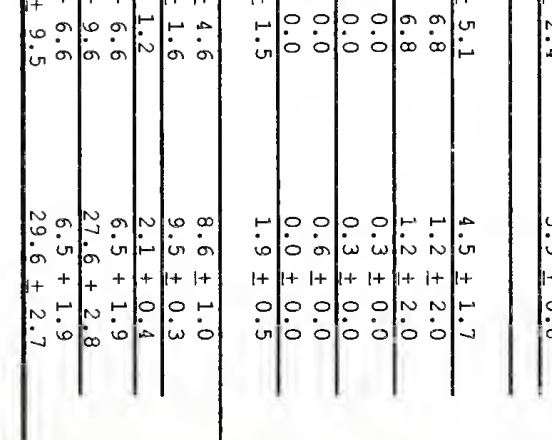

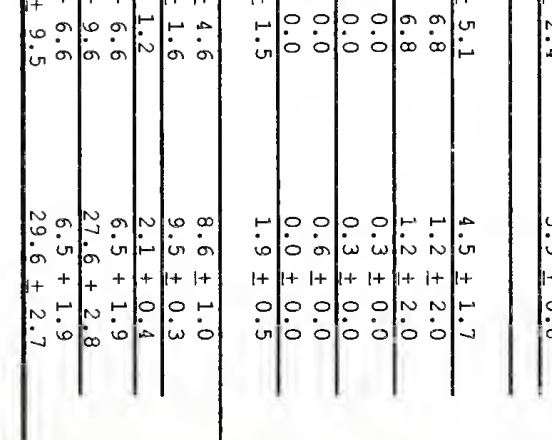

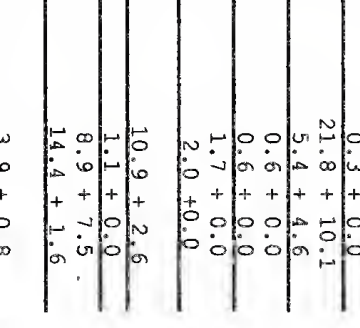

$\left.1\left|0^{0}\right|^{2}\right|^{2}$ 
Exhibit C: Mark-recapture

population estimatas for the

Blackfoot Rivar 2000

\begin{tabular}{|c|c|c|c|c|c|c|c|c|c|c|c|c|}
\hline stream & $\begin{array}{l}\text { River Mile } \\
\text { Mid-point }\end{array}$ & $\begin{array}{l}\text { Location } \\
(T, R, S)\end{array}$ & $\begin{array}{c}\text { Date } \\
\text { Sampled }\end{array}$ & $\begin{array}{l}\text { Section } \\
\text { Length }\end{array}$ & $\begin{array}{c}\text { Specie } \\
\mathrm{s}\end{array}$ & $\begin{array}{l}\text { Size } \\
\text { Class }\end{array}$ & Marked & $\begin{array}{c}\text { Capture } \\
\mathrm{d}\end{array}$ & $\begin{array}{c}\text { Recapture } \\
d\end{array}$ & $\begin{array}{l}\text { Efficien } \\
\text { cy (R/C) }\end{array}$ & $\begin{array}{l}\text { Total Estim } \\
\pm 95 \mathrm{CI}\end{array}$ & $\begin{array}{l}\text { Estim/1000' } \\
\pm 958 \mathrm{CI}\end{array}$ \\
\hline \multirow[t]{4}{*}{$\begin{array}{l}\text { Blackfoot } \\
\text { River } \\
\text { Johnsrud }\end{array}$} & \multirow[t]{4}{*}{13.5} & \multirow[t]{4}{*}{$\begin{array}{l}13 \mathrm{~N}, 16 \mathrm{~W}, \\
\operatorname{Sec} 6\end{array}$} & \multirow[t]{4}{*}{$11-\mathrm{Mav}-00$} & \multirow[t]{4}{*}{18700} & $\mathrm{CT}$ & $\begin{array}{c}6.0-11.9 \\
>12.0 \\
\end{array}$ & $\begin{array}{l}57 \\
15 \\
\end{array}$ & $\begin{array}{l}77 \\
16 \\
\end{array}$ & $\begin{array}{c}17 \\
3 \\
\end{array}$ & $\begin{array}{l}0.22 \\
0.19 \\
\end{array}$ & $\begin{array}{l}250 \pm 101 \\
67 \pm 52\end{array}$ & $\begin{array}{l}13.4 \pm 5.3 \\
3.6 \pm 2.7 \\
\end{array}$ \\
\hline & & & & & DV & $>6.0$ & 18 & 12 & 2 & 0.17 & $81 \pm 71$ & $4.3 \pm 3.7$ \\
\hline & & & & & LI & $>6.0$ & 81 & 82 & 18 & 0.22 & $357 \pm 140$ & $19.1 \pm 7.4$ \\
\hline & & & & & RB & $\begin{array}{c}5.0-10.0 \\
10.0- \\
11.9 \\
>12.0 \\
\end{array}$ & $\begin{array}{l}291 \\
81 \\
77 \\
\end{array}$ & $\begin{array}{l}374 \\
73 \\
55 \\
\end{array}$ & $\begin{array}{l}58 \\
11 \\
12 \\
\end{array}$ & $\begin{array}{l}0.16 \\
0.15 \\
0.22 \\
\end{array}$ & $\begin{array}{c}1855 \pm 440 \\
505 \pm 256 \\
355 \pm 157 \\
\end{array}$ & $\begin{array}{l}99.2 \pm 22.3 \\
27 \pm 13.4 \\
17.9 \pm 8.2 \\
\end{array}$ \\
\hline $\begin{array}{l}\text { Scotty Brown } \\
\text { Bridge }\end{array}$ & 43.9 & $\begin{array}{c}15 \mathrm{~N}, 13 \mathrm{~W}, 3 \\
2\end{array}$ & 12-Mav-00 & 20064 & $\mathrm{CT}$ & $6.0-11.9$ & 48 & 76 & 23 & 0.30 & $156 \pm 52$ & $7.8 \pm 2.5$ \\
\hline \multirow[t]{4}{*}{ Section } & & & & & & $>12.0$ & 94 & 44 & 12 & 0.27 & $238+148$ & $16.3 \pm 7.2$ \\
\hline & & & & & DV & $>6.0$ & 30 & 19 & 3 & 0.16 & $154 \pm 123$ & $7.7 \pm 6.0$ \\
\hline & & & & & LI & $\begin{array}{c}6.0-11.9 \\
>12.0 \\
\end{array}$ & $\begin{array}{l}50 \\
65 \\
\end{array}$ & $\begin{array}{l}68 \\
73 \\
\end{array}$ & $\begin{array}{l}13 \\
20 \\
\end{array}$ & $\begin{array}{l}0.19 \\
0.27 \\
\end{array}$ & $\begin{array}{c}250 \pm 115 \\
232 \pm 84 \\
\end{array}$ & $\begin{array}{l}12.5 \pm 5.6 \\
11.5 \pm 4.1 \\
\end{array}$ \\
\hline & & & & & $\mathrm{RB}$ & $\begin{array}{c}4.0-10.9 \\
11.0- \\
13.9 \\
>14.0\end{array}$ & $\begin{array}{l}95 \\
43 \\
46\end{array}$ & $\begin{array}{l}104 \\
33 \\
66\end{array}$ & $\begin{array}{c}19 \\
8 \\
16\end{array}$ & $\begin{array}{l}0.18 \\
0.24 \\
0.24 \\
\end{array}$ & $\begin{array}{l}503 \pm 198 \\
165 \pm 90 \\
184 \pm 75\end{array}$ & $\begin{array}{l}25.1 \pm 9.6 \\
8.2 \pm 4.4 \\
9.2 \pm 3.7 \\
\end{array}$ \\
\hline
\end{tabular}


Exhibit D: Summary of stream discharge measurements for 2000.

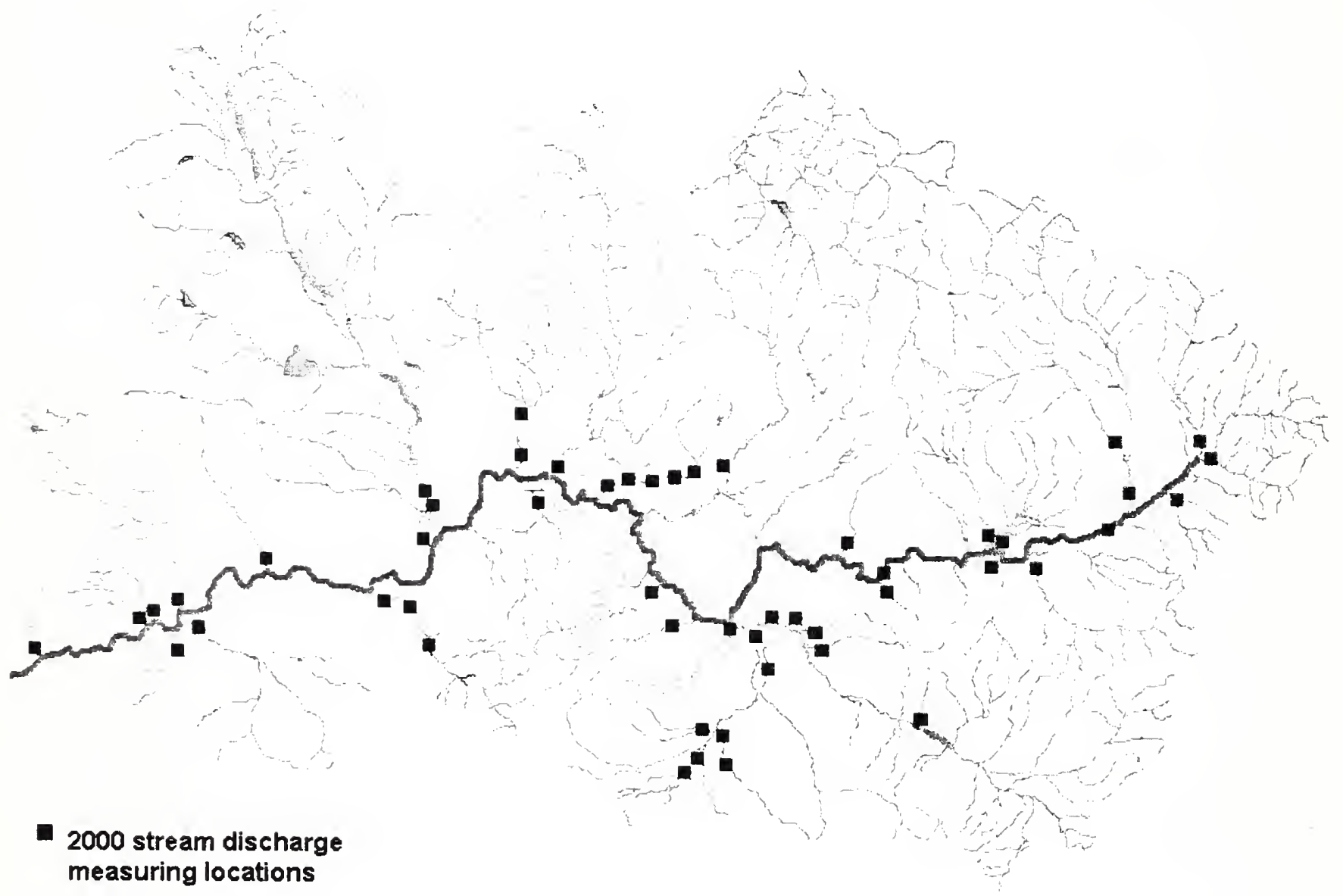


Exhibit D (continued):Summary of Stream Discharge Measurements for 2000.

Stream
Alice Creek
Arrastra Creek
Bear Creek
Belmont Creek
Beaver Creek
Black Bear Creek
Blackfoot River
Blackfoot River
Blackfoot River

Boyd Irrigation Ditch

Chamberlain Creek

Chicken Creek

Chimney Cr. trib. to Douglas Cr.

Chimney Cr. trib. to Douglas $\mathrm{Cr}$.

Cleanwater River

Clearwater Irrrigation Ditch

Clearwater River

Copper Creek

Cottonwood Creek

Cottonwood Cr.trib.to Nevada Cr.

Douglas Creek

Elk Creek

Elk Creek

Elk Creek

Elk Creek

Gold Creek

Hogum Creek

Johnson Creek

Keep Cool Creek

Landers Fork

Monture Creek

Moose Creek

Murray Creek

Murphy Diversion Ditch

Nevada Creek

Nevada Spring Crek

Nevada Spring Creek

Poorman Creek

Spring Cr. trib to North Fork

Sturgeon Creek

Twin Creek, West

Twin Creek, East

Twin Creek, East

Union Creek

Wales Creek

Warren Creek

Warren Creek

Warren Creek

Warren Creek

Warren Creek

Wasson Creek

Willow Creek

Wilson Creek

Youmame Creek
Legal Discription

$15 N, 7 W, 27 C D$

14N, 10W, 30A

$13 \mathrm{~N}, 16 \mathrm{~W}, 7 \mathrm{C}$

$14 \mathrm{~N}, 16 \mathrm{~W}, 24 \mathrm{C}$

14N, 9W, 22A

$12 \mathrm{~N}, 12 \mathrm{~W}, 23 \mathrm{~B}$

$14 \mathrm{~N}, 10 \mathrm{~W}, 34 \mathrm{~B}$

$14 \mathrm{~N}, 8 \mathrm{~W}, 22 \mathrm{~A}$

$15 \mathrm{~N}, 7 \mathrm{~W}, 35 \mathrm{~B}$

15N, 13W, 17A

$14 \mathrm{~N}, 13 \mathrm{~W}, 4 \mathrm{D}$

$12 \mathrm{~N}, 10 \mathrm{~W}, 11 \mathrm{D}$

$12 \mathrm{~N}, 12 \mathrm{~W}, 12 \mathrm{~A}$

$12 \mathrm{~N}, 12 \mathrm{~W}, 24 \mathrm{~A}$

$14 \mathrm{~N}, 14 \mathrm{~W}, 16 \mathrm{C}$

$15 \mathrm{~N}, 14 \mathrm{~W}, 4 \mathrm{~B}$

$15 \mathrm{~N}, 14 \mathrm{~W}, 4 \mathrm{~B}$

$15 \mathrm{~N}, 8 \mathrm{~W}, 25 \mathrm{C}$

$15 \mathrm{~N}, 13 \mathrm{~W}, 29 \mathrm{~B}$

$13 \mathrm{~N}, 11 \mathrm{~W}, 28 \mathrm{~A}$

$13 \mathrm{~N}, 11 \mathrm{~W}, 16 \mathrm{~B}$

$14 \mathrm{~N}, 15 \mathrm{~W}, 36 \mathrm{~A}$

$14 \mathrm{~N}, 15 \mathrm{~W}, 36 \mathrm{~A}$

$14 \mathrm{~N}, 14 \mathrm{~W}, 32 \mathrm{C}$

$13 \mathrm{~N}, 14 \mathrm{~W}, 16 \mathrm{~B}$

14N, 16W, 30D

$14 \mathrm{~N}, 7 \mathrm{~W}, 8 \mathrm{~A}$

$13 \mathrm{~N}, 18 \mathrm{~W}, 14 \mathrm{~B}$

$14 \mathrm{~N}, 9 \mathrm{~W}, 23 \mathrm{~A}$

$14 \mathrm{~N}, 8 \mathrm{~W}, 12 \mathrm{C}$

$15 \mathrm{~N}, 13 \mathrm{~W}, 27 \mathrm{C}$

$14 \mathrm{~N}, 10 \mathrm{~W}, 34 \mathrm{C}$

$12 \mathrm{~N}, 12 \mathrm{~W}, 12 \mathrm{C}$

$15 \mathrm{~N}, 11 \mathrm{~W}, 16 \mathrm{~A}$

$13 \mathrm{~N}, 11 \mathrm{~W}, 7 \mathrm{C}$

$13 \mathrm{~N}, 11 \mathrm{~W}, 10 \mathrm{C}$

$13 \mathrm{~N}, 11 \mathrm{~W}, 11 \mathrm{~B}$

$14 \mathrm{~N}, 9 \mathrm{~W}, 22 \mathrm{C}$

$15 \mathrm{~N}, 11 \mathrm{~W}, 16 \mathrm{~A}$

$12 \mathrm{~N}, 12 \mathrm{~W}, 14 \mathrm{~A}$

$13 \mathrm{~N}, 17 \mathrm{~W}, 2 \mathrm{C}$

$13 \mathrm{~N}, 17 \mathrm{~W}, 2 \mathrm{~A}$

$13 \mathrm{~N}, 17 \mathrm{~W}, 2 \mathrm{~A}$

$13 \mathrm{~N}, 16 \mathrm{~W}, 6 \mathrm{D}$

$14 \mathrm{~N}, 12 \mathrm{~W}, 34 \mathrm{~B}$

$15 \mathrm{~N}, 12 \mathrm{~W}, 31 \mathrm{C}$

$15 \mathrm{~N}, 12 \mathrm{~W}, 31 \mathrm{AD}$

$15 \mathrm{~N}, 12 \mathrm{~W}, 32 \mathrm{~A}$

$15 \mathrm{~N}, 12 \mathrm{~W}, 33 \mathrm{~B}$

$15 \mathrm{~N}, 12 \mathrm{~W}, 35 \mathrm{~A}$

$13 \mathrm{~N}, 11 \mathrm{~W}, 13 \mathrm{~B}$

14N, 9W, 28D

$13 \mathrm{~N}, 11 \mathrm{~W}, 24 \mathrm{~A}$

$13 \mathrm{~N}, 12 \mathrm{~W}, 11 \mathrm{~B}$
Stream mlle

0.1

0.3

1.1

0.1

0.2

0.1

94.5

114.5

124.2

4.9

1.9

0.1

0.1

2.5

0.1

3.5

3.5

1.1

1.1

2.4

0.5

1.1

1.1

3

6.2

0.1

0.4

0.1

1.2

1.1

0.1

0.4

0.1

1.8

0.3

0.8

2.8

0.1

1.8

0.1

0.1

0.1

0.1

0.8

0.1

1.1

2.1

3.6

4.3

7.4

0.6

1.5

0.2

1.2

\section{Date}

23-Aug-00

23-Aug-00

24-Aug-00

24-Aug-00

23-Aug- 00

10-Jul-00

23-Aug-00

23-Aug-00

23-Aug- 00

26-Jul-00

22-Aug-00

17-Jul-00

11-Jul-00

11-Jut-00

22-Aug-00

22-Aug-00

22-Aug- 00

23-Aug-00

22-Aug-00

2-Aug-00

2-Aug- 00

24-Aug-00

7-Sep-00

7-Sер-00

7-Sep-00

21-Aug-00

23-Aug-00

24-Aug-00

23-Aug-00

23-Aug-00

22-Aug-00

23-Aug-00

11-Jul-00

20-Jul-00

24-Aug-00

26-Sep-00

26-Sep-00

29-Aug-00

20-Jul-00

6-Jul-00

24-Aug-00

7-Jul-00

24-Aug-00

24-Aug-00

08-Aug-00

30-Aug-00

30-Aug-00

30-Aug-00

22-Aug-00

30-Aug-00

19-Jul-00

23-Aug-00

19-Jul-00

08-Aug-00

$\begin{array}{cc}\text { Discharge } \mathrm{ft}^{3} / \mathrm{s} & \text { Location } \\ 4.9 & \text { Hwy 200 } \\ 10.4 & \text { Hwy 200 } \\ 2.02 & \text { Restortion site } \\ 6.37 & \text { Mouth } \\ 4.51 & \text { Hwy 200 }\end{array}$

Mouth, confluence with Sturgeon $\mathrm{Cr}$.

Ogden Mtn. Rd.

4X4 Rd. above Lincoln

Flesher Pass Rd.

Bandy Ranch, below fish screen

Chamberlain $\mathrm{Cr}$. Rd. xing culvert

Mouth

Mouth

In canyon on Manley Ranch

Mouth

Clearwater campground

Above Hwy 200, behind campground

Sucker Cr. Rd. bridge Huy 200

Orvando-Helmville Rd. xing

Mouth

Hwy 200

Hwy 200

Sunset Hill Rd. xing

1 mile upstm. of Cap Wallace Rd. Mouth

PC bridge xing

Mouth

Huy 200

Huy 200

Mouth

Forest Sevice Rd. 1163 xing

Mouth

In ditch

Upstm of mouth, Coughlin bridge

Bridge behind old homestead

Dwnstrm. of Coughlin's upper fence Mouth

Upstm. of Murphy diversion

Mouth, confluence with Douglas $\mathrm{Cr}$.

Mouth

Mouth

Mouth

Bear Cr. Rd. xing culvert Mouth

Upstm. of lower bridge

Upstm. of middle bridge

Dwnstm. of north entrance rd. xing

Orvando-Helmville Rd. xing Hwy 200

Dwnstm. of Hwy 141 culvert Dalton Mtn. Rd. xing

Dwnstm. of Hwy 141 culvert

Dwnstm. of fence, Myers Ranch Co. 


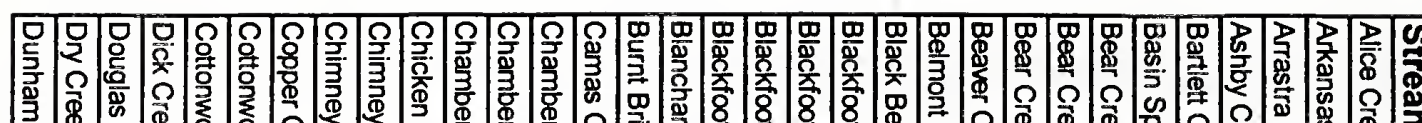

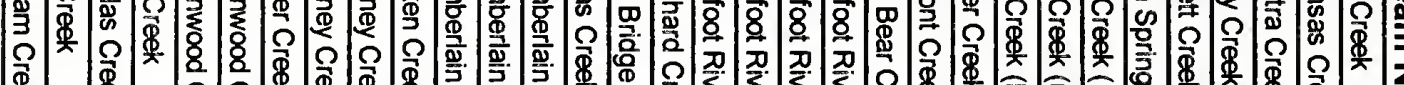

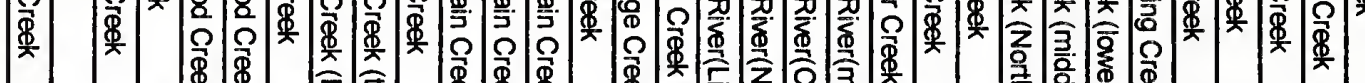

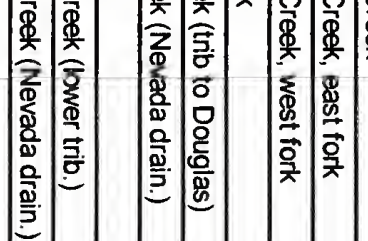

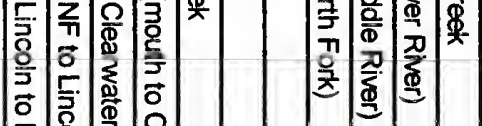

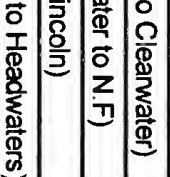

$\frac{3}{3}$

$x \times x$

$x$

$x \times$

$x|x| x$

$x \mid x$

$\times$

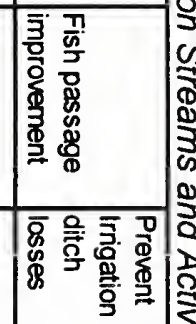

$\times$

$\times$

总总高

$x \quad x$

$x$

$x \mid x$

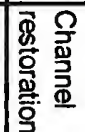

$x$

$\times$

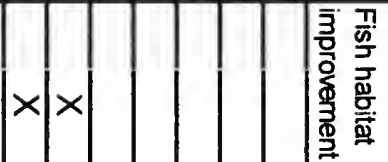

$x|x| x \mid x$

$\times$

$x$

$x \times$

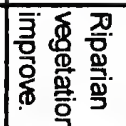

$x$

$x \quad x \quad x$

$x \times$

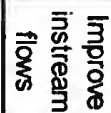

$x$

$x \mid x$

$x$

产

흥

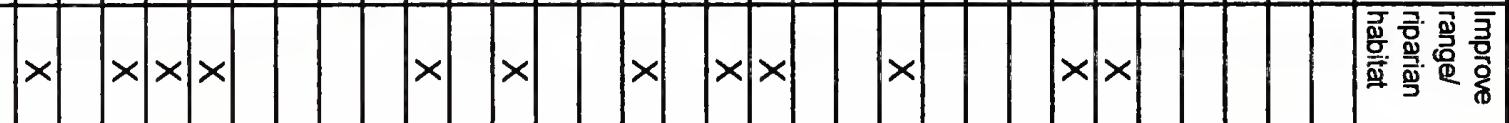

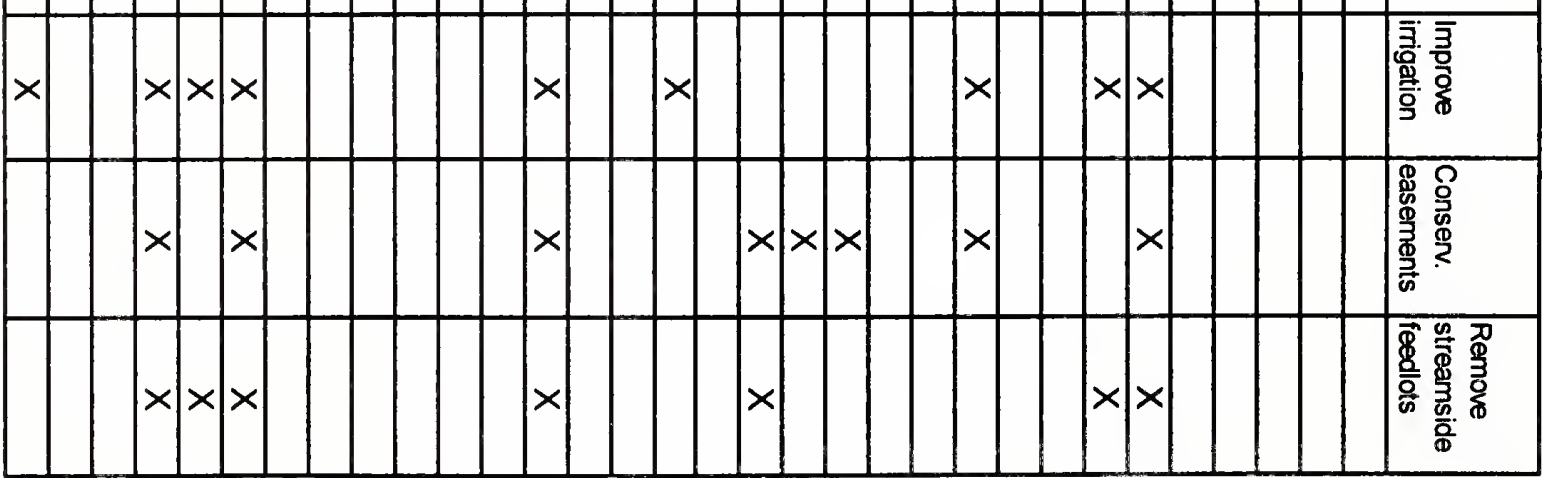




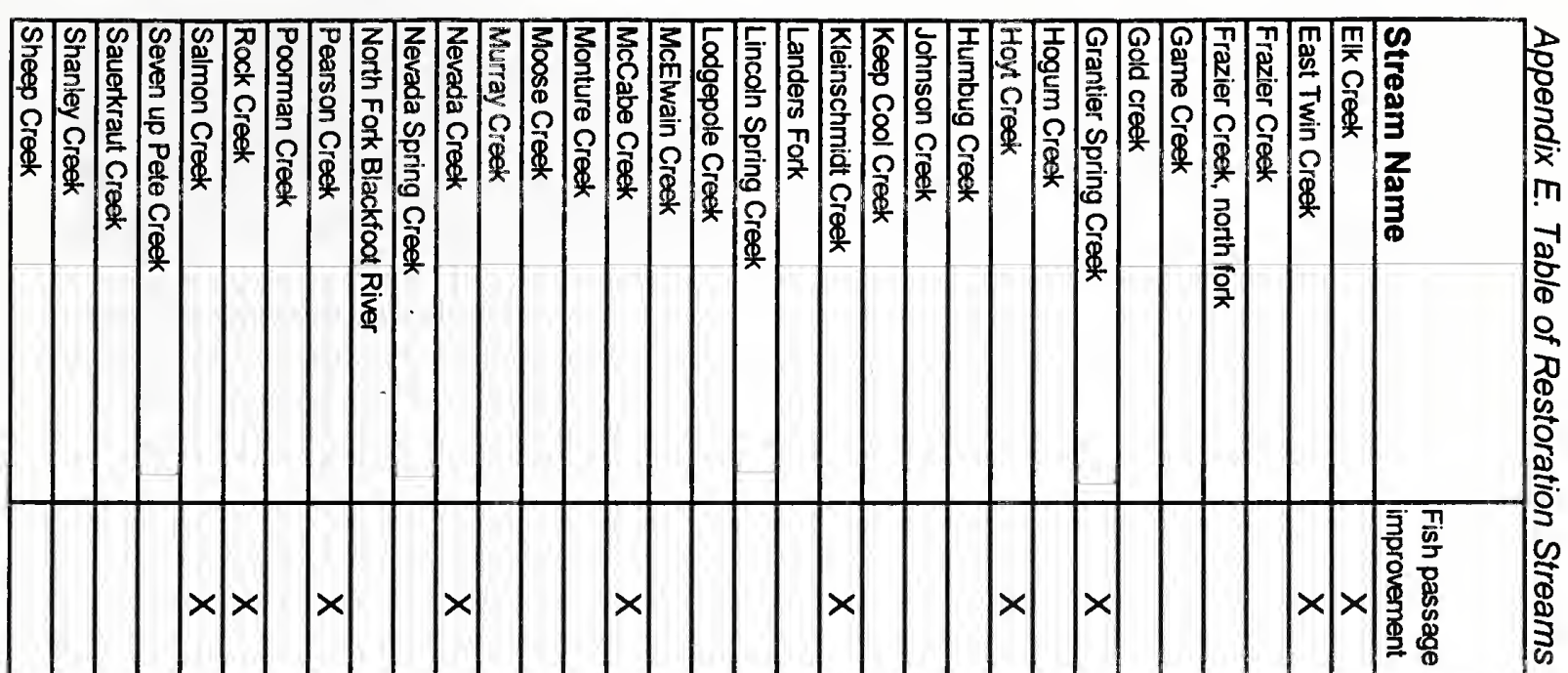

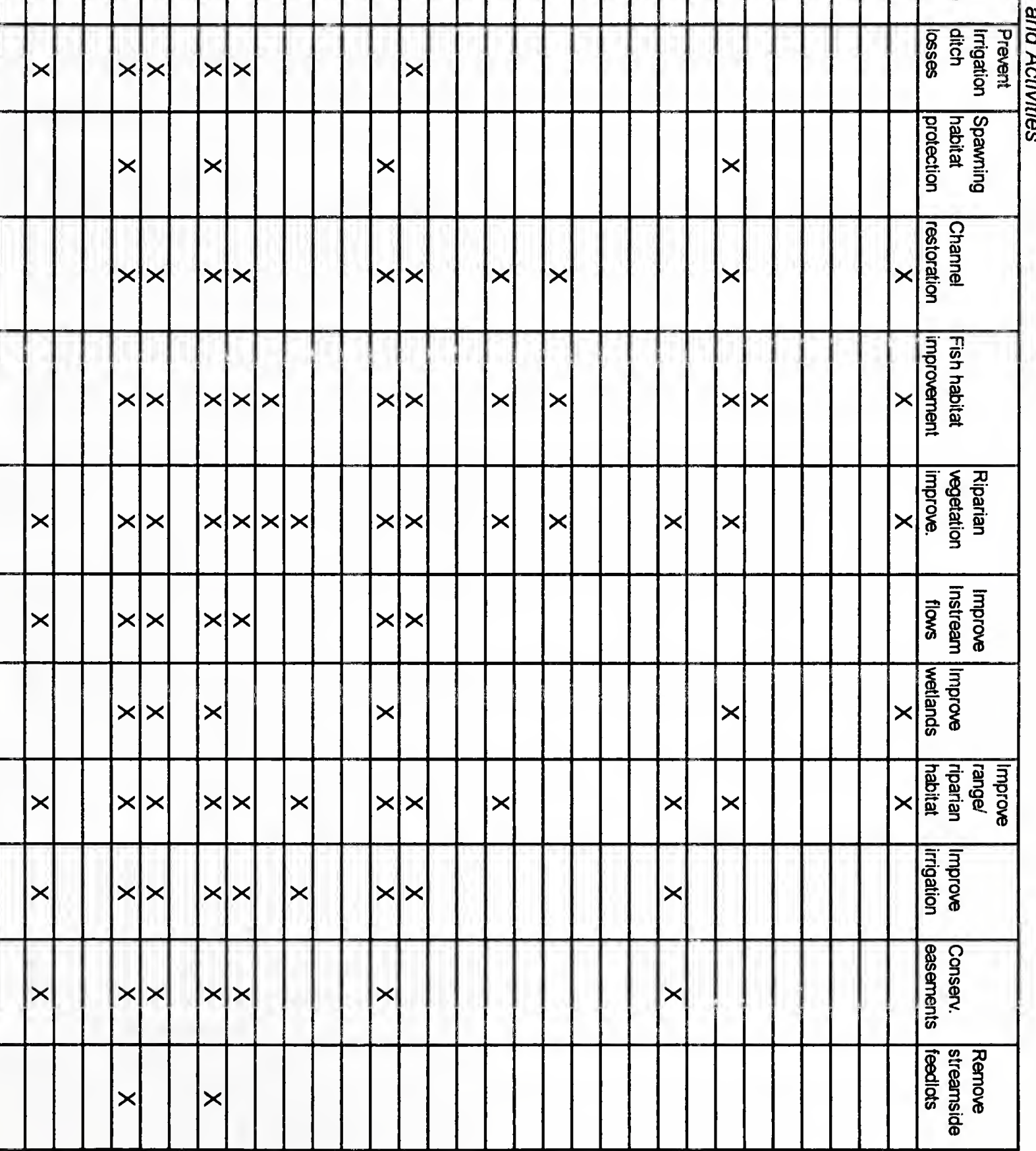




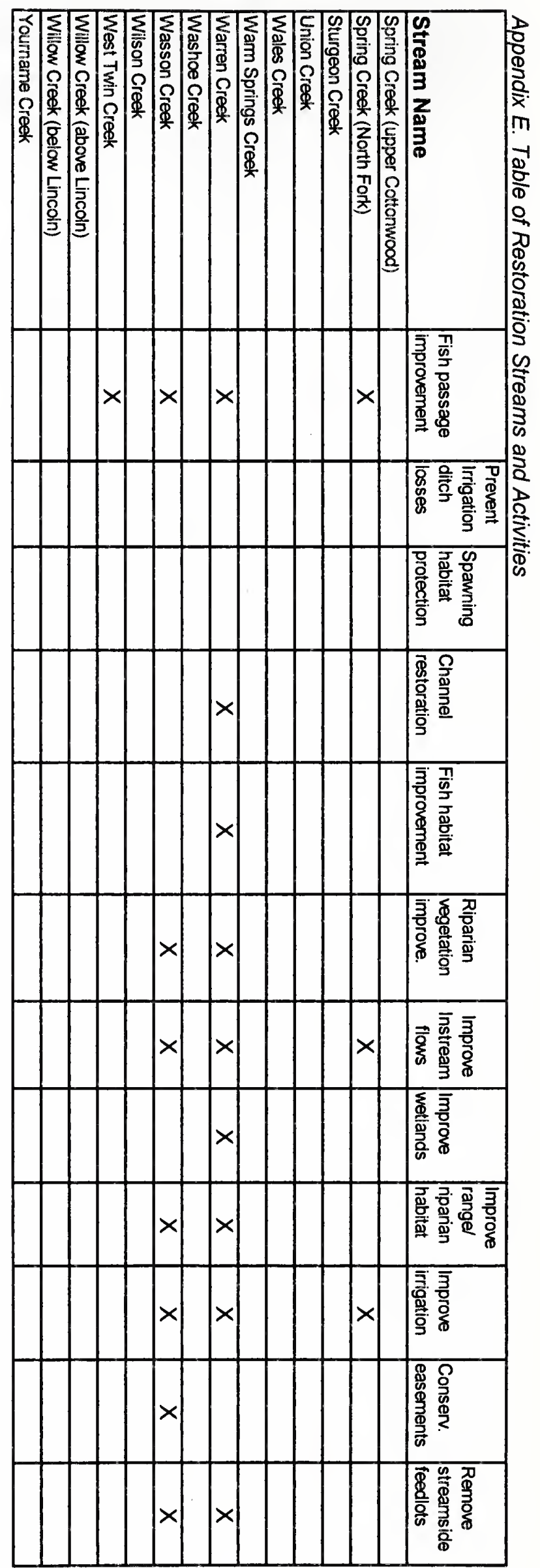


Exhibit F: Conceptual restoration process for private land.

\section{1) Fish Population Evaluation}

Gain access to private land and invite landowners to participate in evaluation.

-Inventory fish populations.

-Species composition (native species presence), population densities, lifehistory characteristics.

-Evaluate habitat conditions (and possible disease status of stream).

-Identify limiting factors (i.e. flow problems, habitat condition, etc.).

-Identify cause of limiting factors (i.e. over-grazing, irrigation practices).

-Present results and interpretation of surveys to landowner.

-Introduce restoration concept.

-Evaluate initial landowner interest in possible project.

Report summary resource findings to watershed groups and in bi-annual report.

\section{2) Pre-Project Phase}

If fish population problems and limiting factors are identified, if a restoration priority exists, and if initial landowner interest in restoration is positive.

-Identify restoration options that meet fish population restoration objective.

-Communicate range of restoration options and objectives to landowner

-Identify landowner objectives (eg. increase hay production, improve water quality).

-Identify options for meeting landowner objectives (i.e. improve irrigation efficiency, develop riparian grazing system).

-Enlist agency specialists (water rights, range con. engineer, etc.) as needed to develop options.

-Identify costs and benefits of possible project.

-Develop conceptual design.

Report pre-project status to watershed groups.

\section{3) Project development Phase}

If resource and landowner objectives can reasonably be met, and if the cooperators commit to a restoration project.

-Complete final project design.

-Usually require outside funding

-Enlist consultants, agency specialists.

-Determine final project costs.

-Identify cost-share options and write grants.

-Future Fishery Grant.

-U.S. Fish and Wildlife.

-Private foundations.

-Landowner contributions.

-Complete final designs and secure final funding.

-Obtain agency clearance/permitting .

-Write Environmental Assessment.

-address comments

-notice of decision 
-Obtain Cultural Survey Clearance (SHIPPO) Permit.

-Streambank Protection Permit (124 or 310).

-Exemption of Surface Water Quality Standards (3a permit).

-Army Corps of Engineers (404) Permit or Nationwide Permit 27.

-Endangered Species (Section 7 bull trout) Permit.

-Obtain additional permits and authorization as needed.

-Enter into Landowner Agreement(s).

-Outline obligations of cooperating parties.

\section{4) Project Implementation Phase}

-Hire consultants and contractors (follow State and Federal procurement policies).

- obtain consultant contract, obtain bid/contract for equipment operator.

-Final project "walk-through" with landowner, consultants, contractors, watershed group and agency representatives.

-Mobilize equipment and personnel to project.

-Ensure contractors and consultants adhere to special permit requirements.

-Coordinate efforts and communicate with all players during this process.

-Unforeseen needs and problems (social and project) will arise during this phase.

-Address unforeseen issues.

-Track project progress and budgets and send invoices to appropriate party.

-Ensure final project meets landowner and resource objectives.

-Report on project to agencies and watershed group.

5) Project Maintenance and Monitoring Phase

-Monitor fish population response in project area over several years.

-Continue to communicate with landowner.

-Address special maintenance needs.

-Report monitoring findings to watershed group and in bi-annual fisheries report.

-Modify restoration philosophies and methods as needed based on monitoring results. 


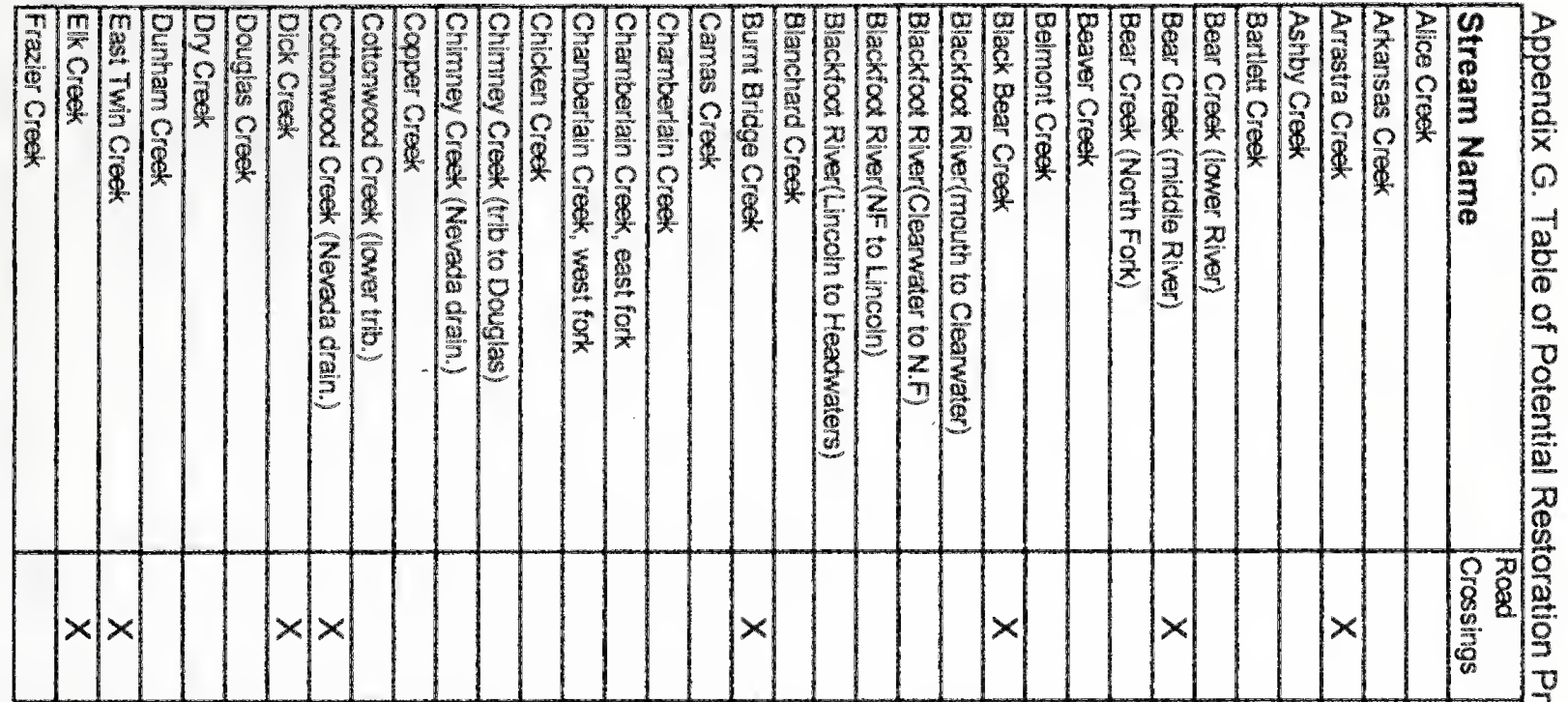

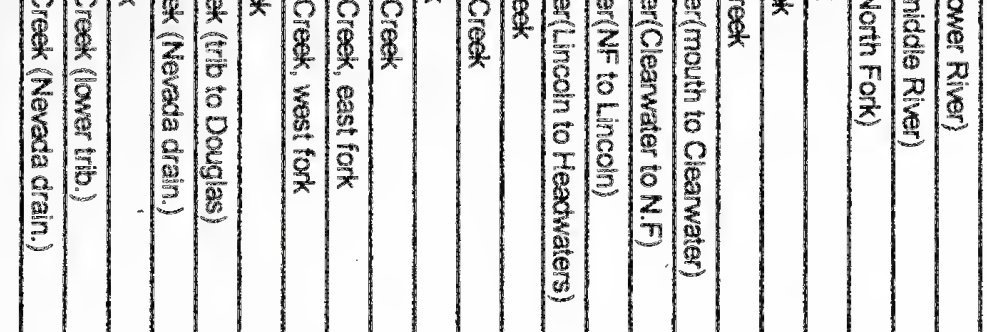

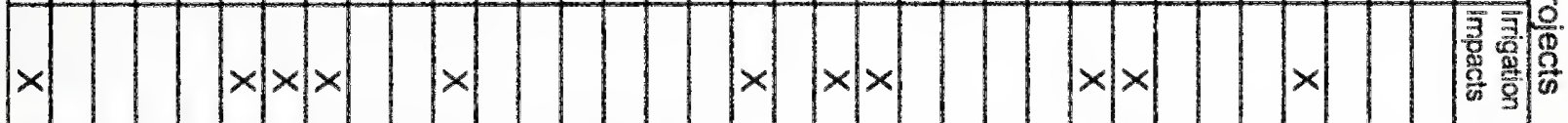

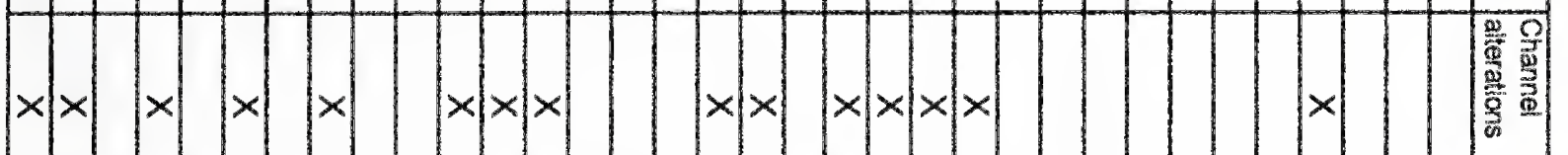

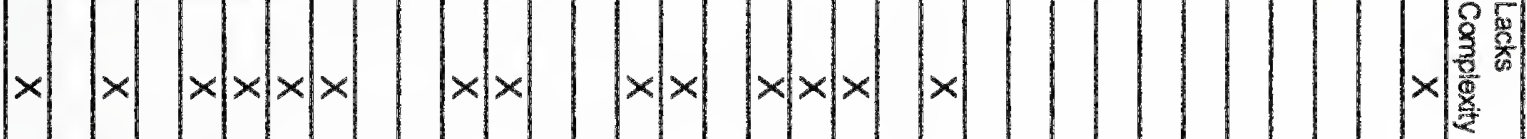

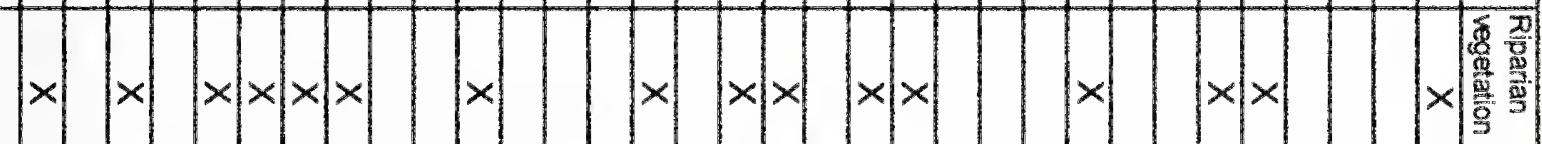

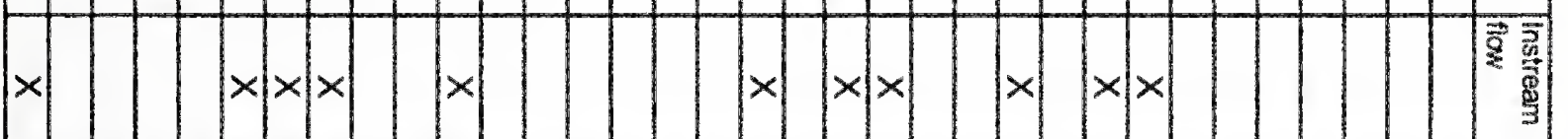

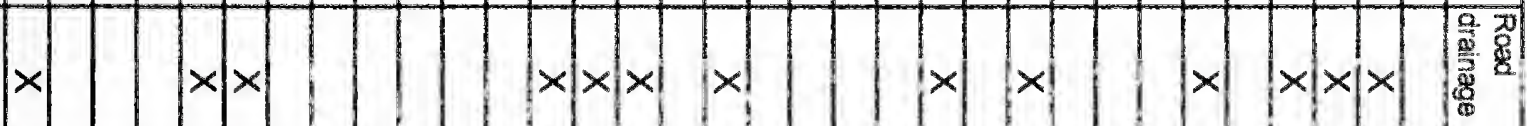

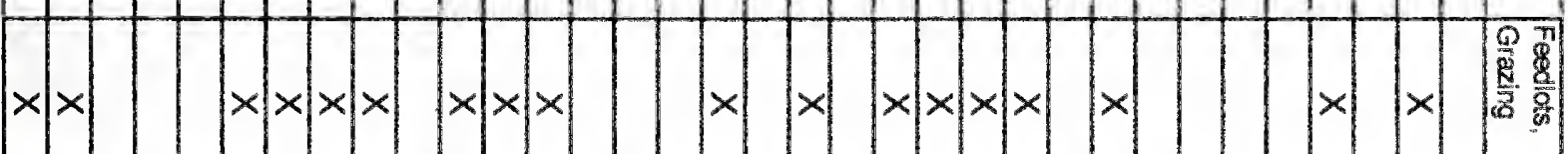

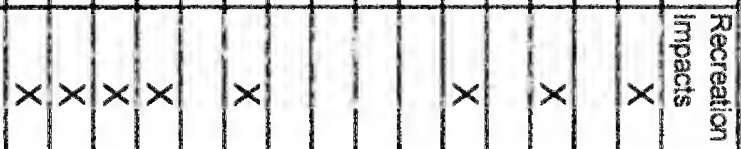

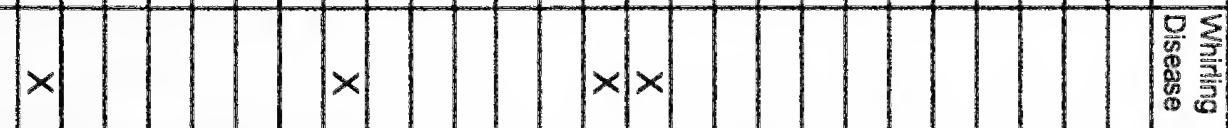




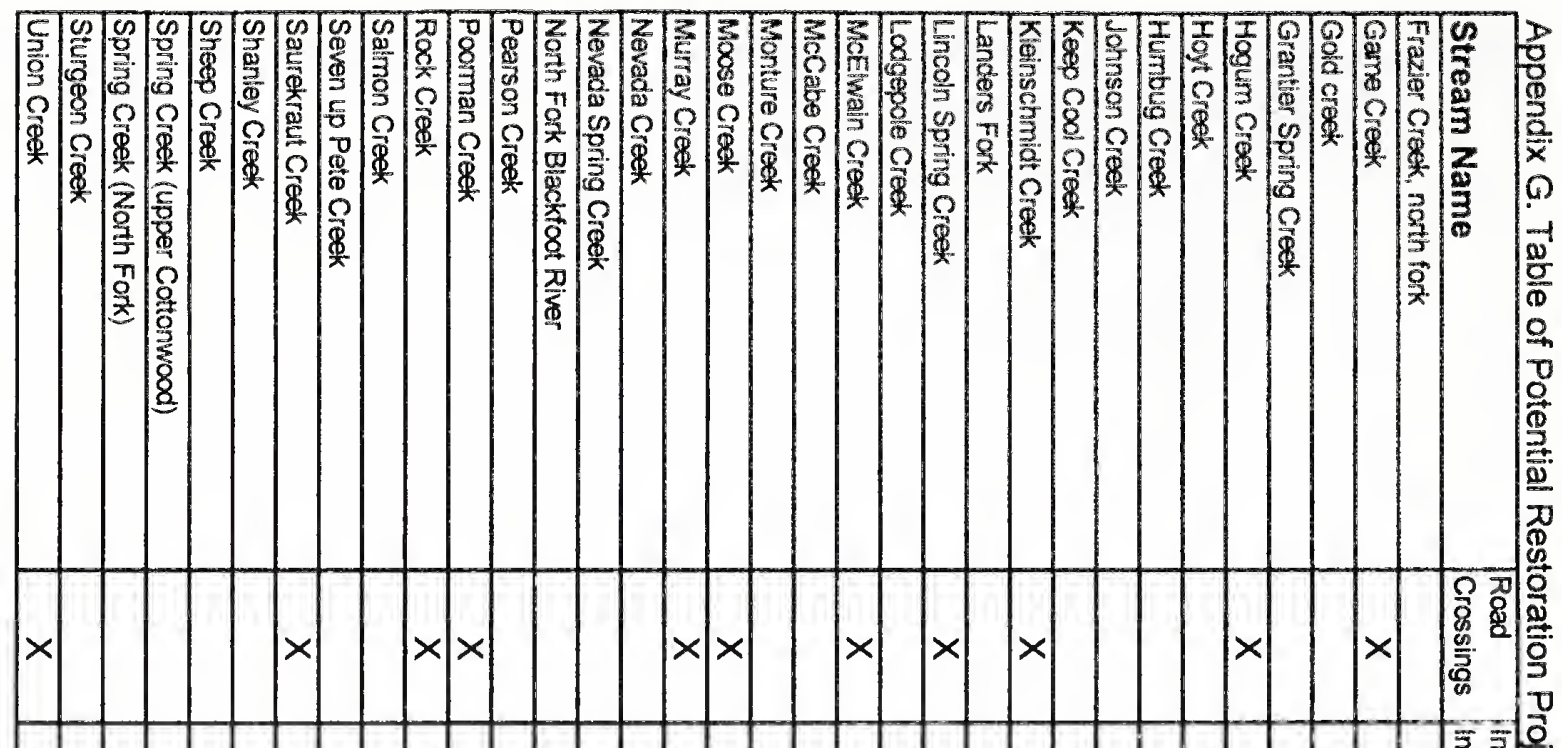

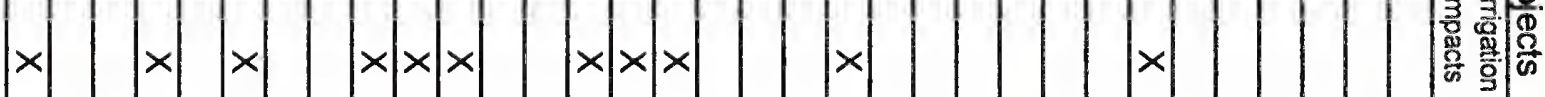

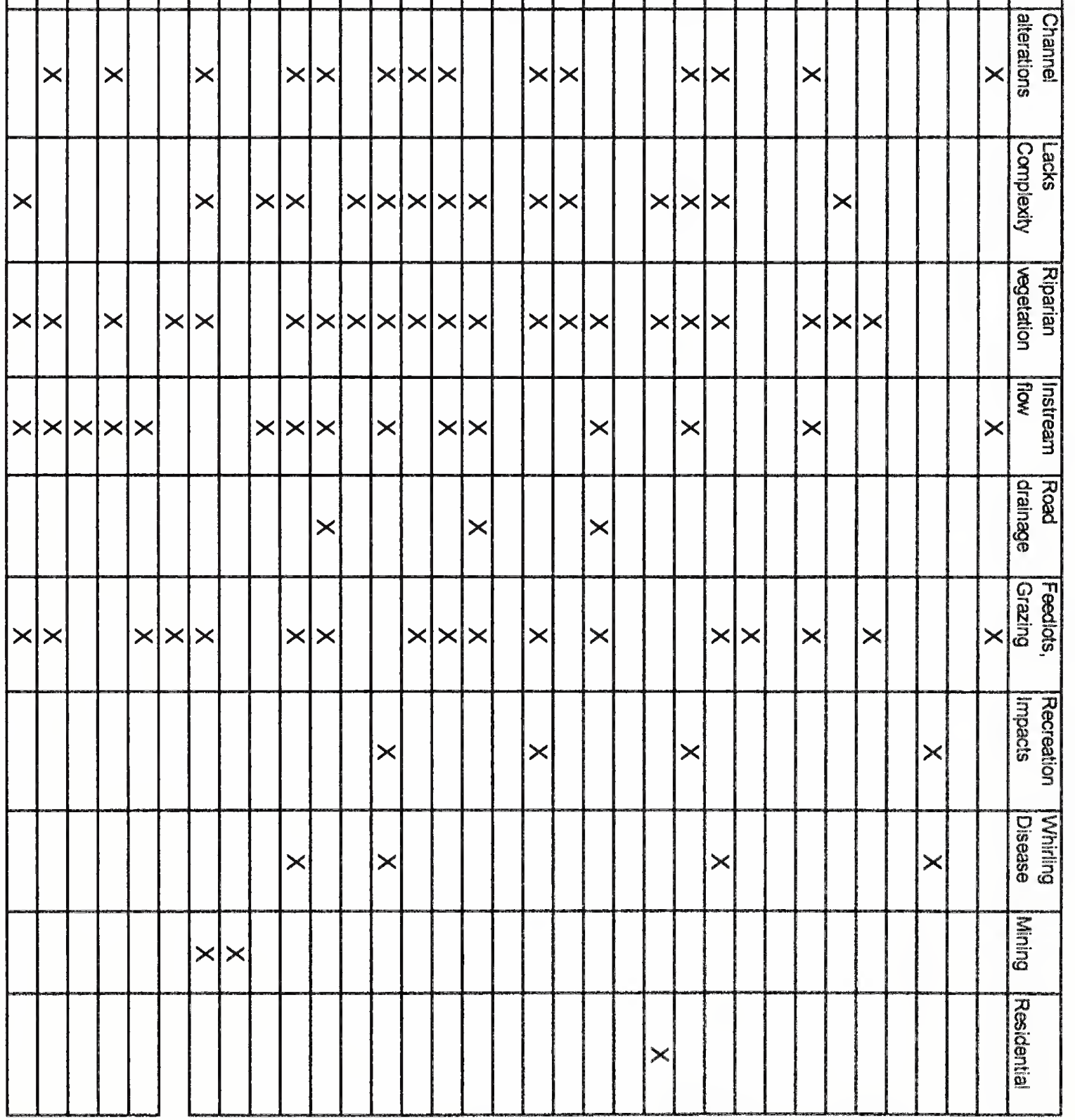




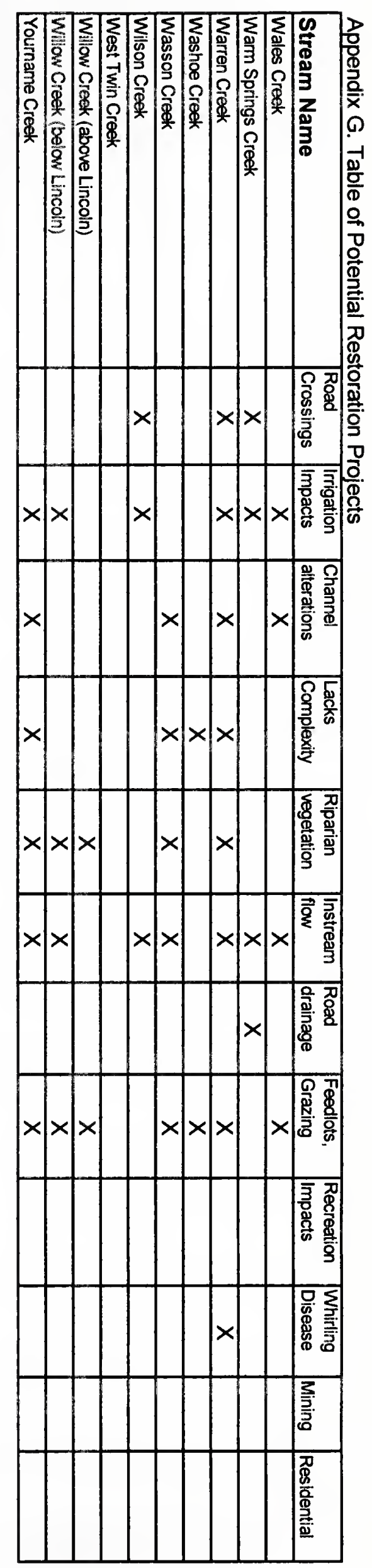




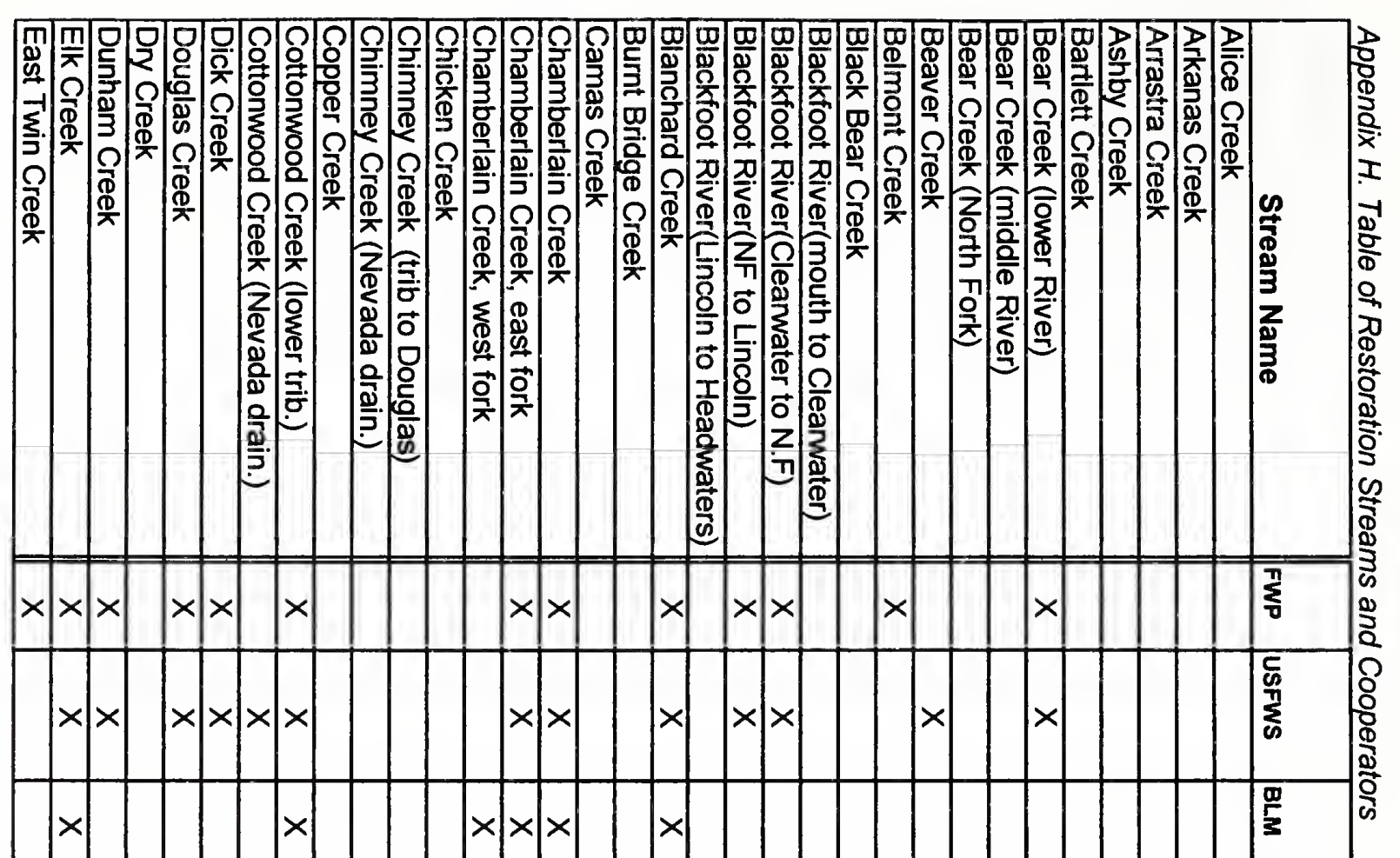

$x \times$

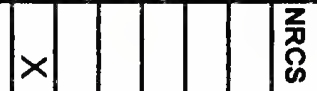

$\times$

点

$\times$

족

$\times$

$\times$

$\times$

超

$x$

疍

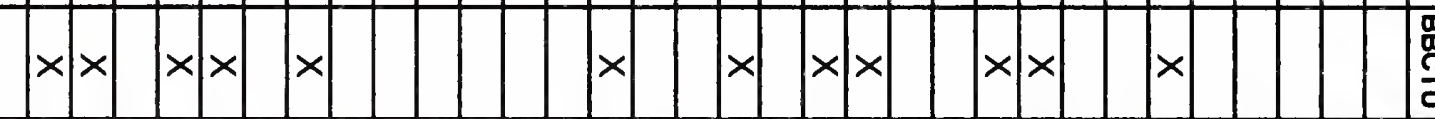

$x \times x \times$

$x \quad x$

$\times$

$x$

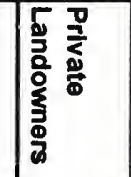

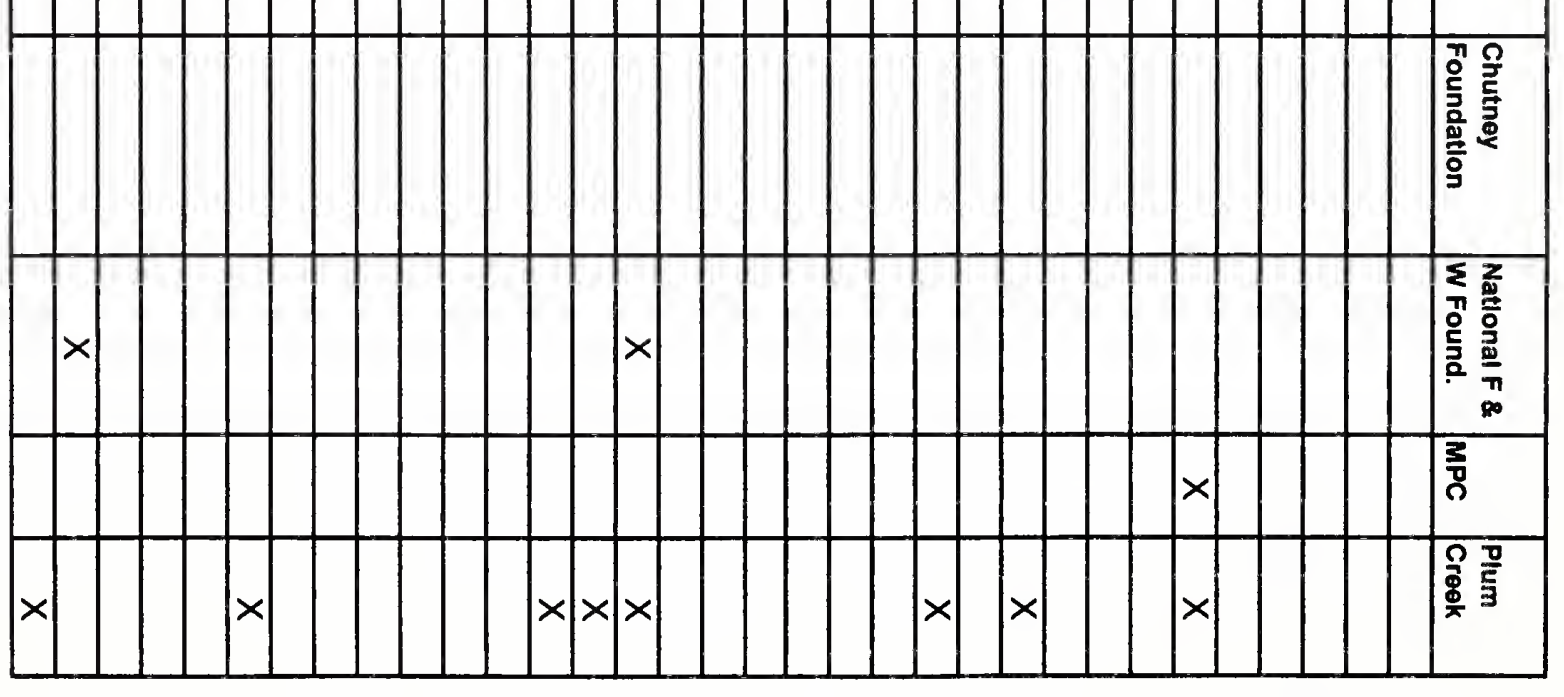




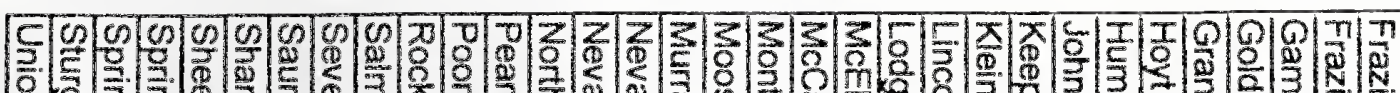

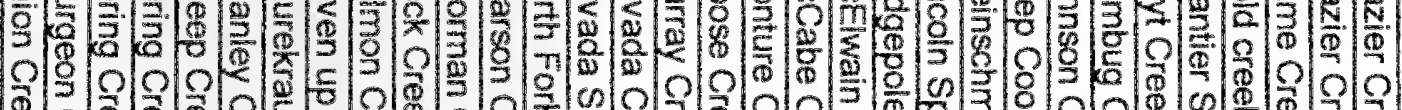

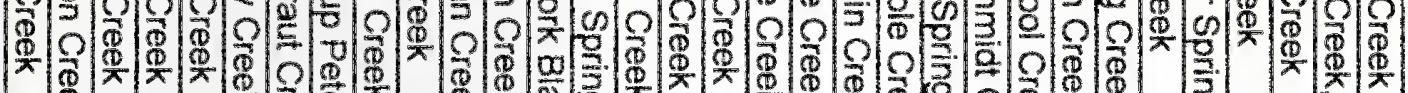

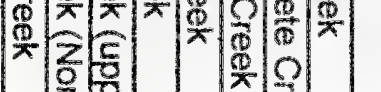

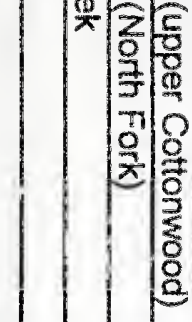
잇

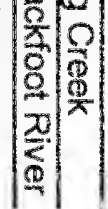

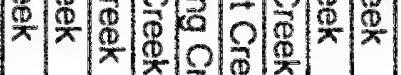
急

言

|

12

要

$\frac{2}{x}$

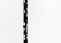

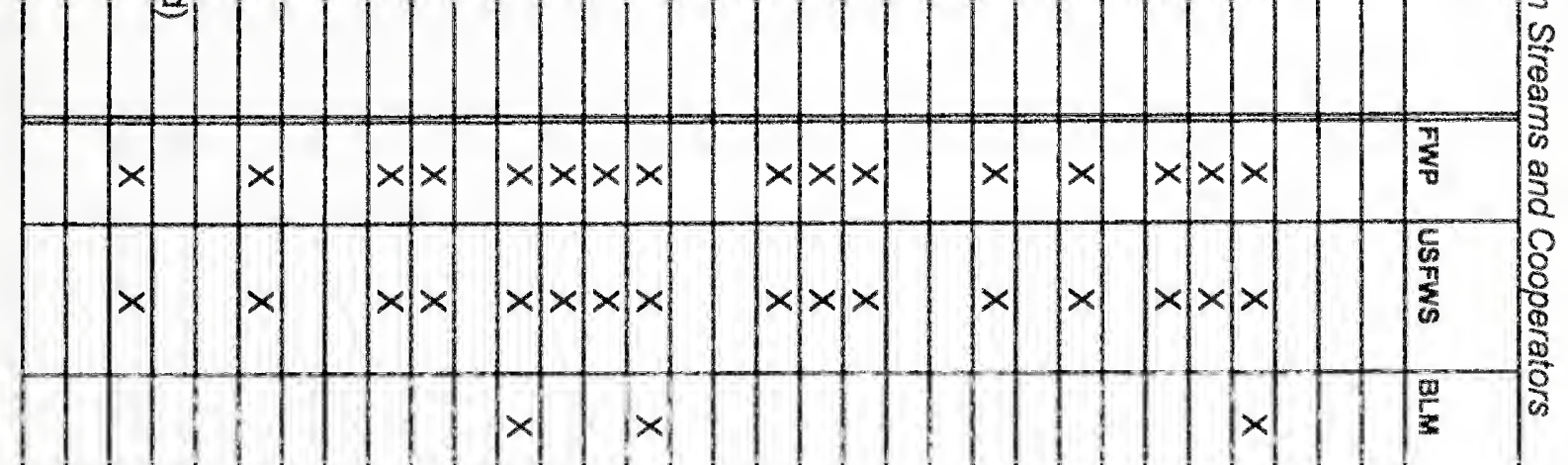

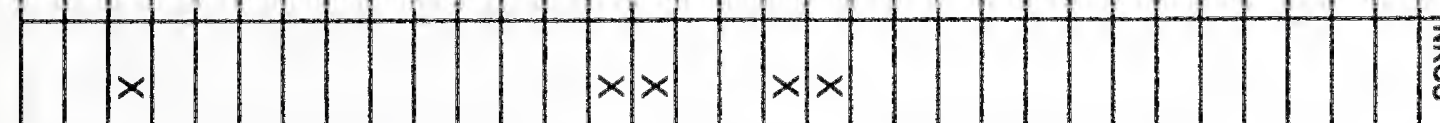

$\times \times$

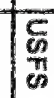

$\times$

$\times$

$\times$

$\frac{x}{9}$

$\times$

$x^{x} x_{x}^{x}$

$\times$

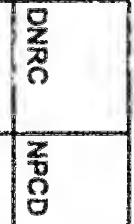

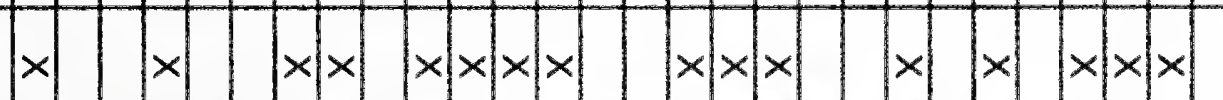

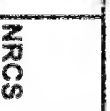

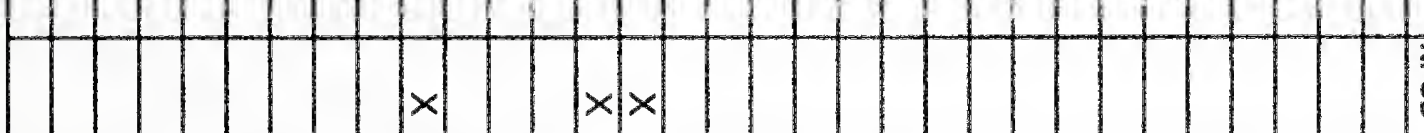

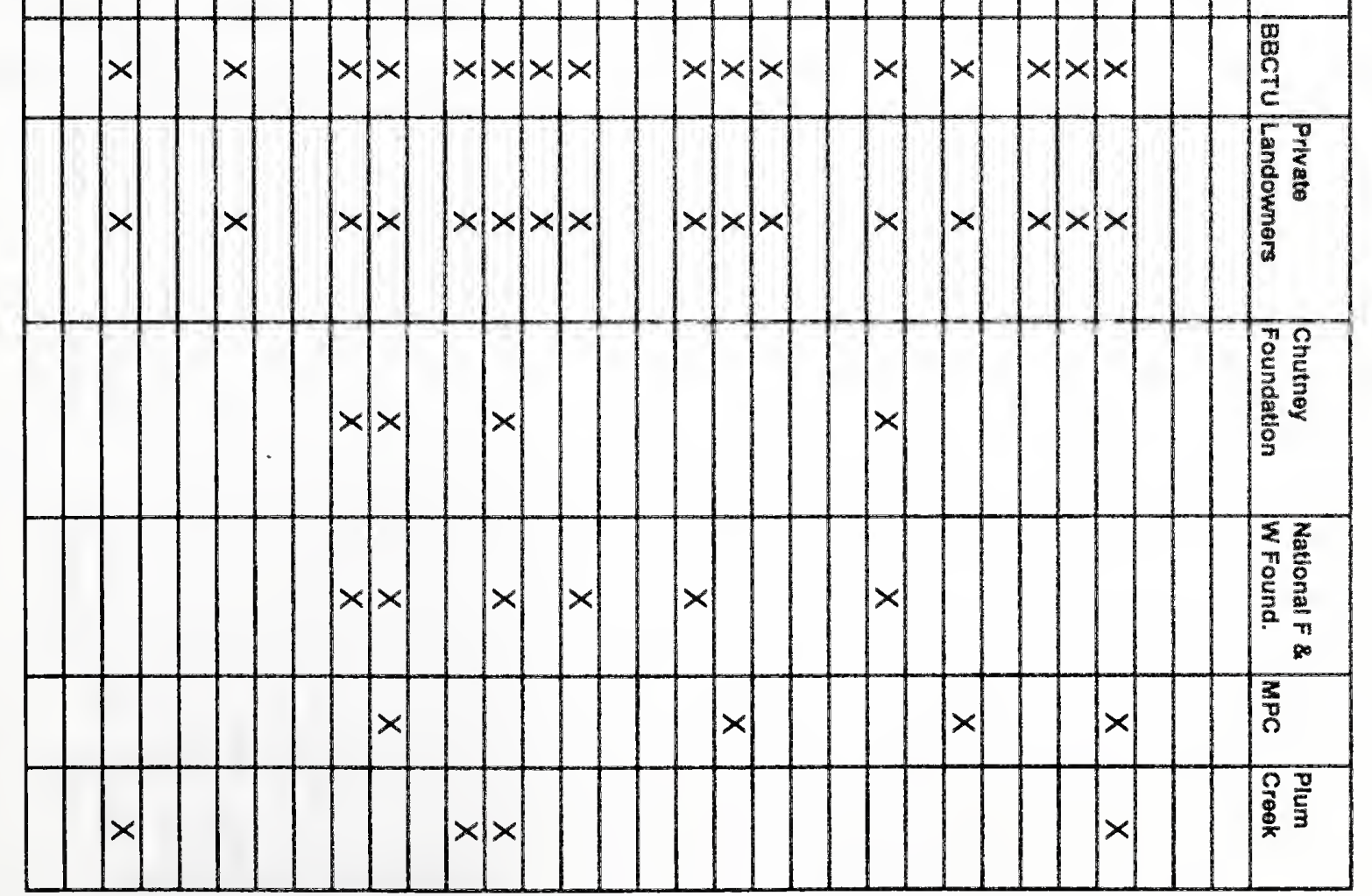


Exhibit I: Summary of water temperature monitoring in the Blackfoot Drainage, 2000.

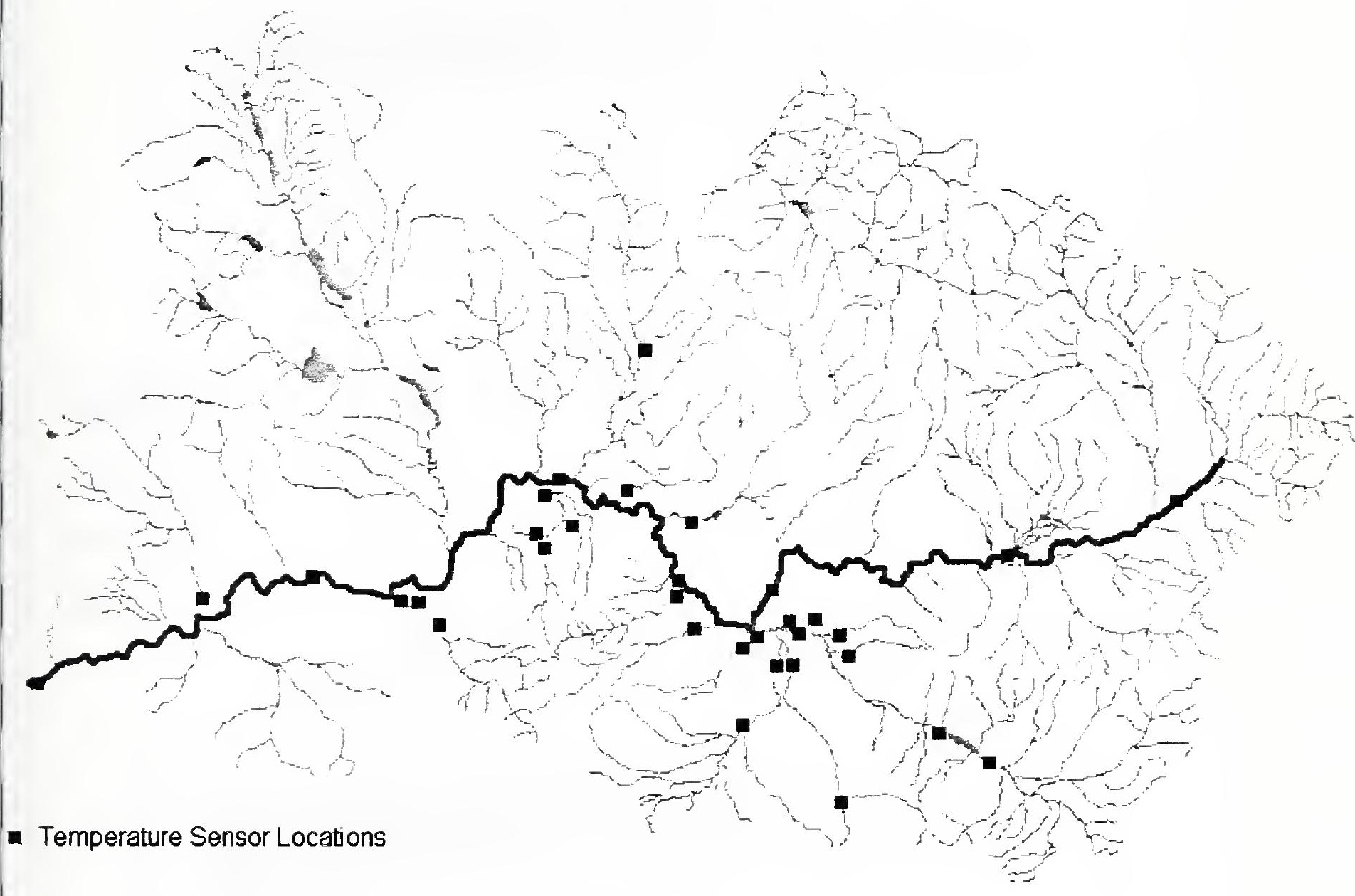




\section{Blackfoot River Below Lincoln}

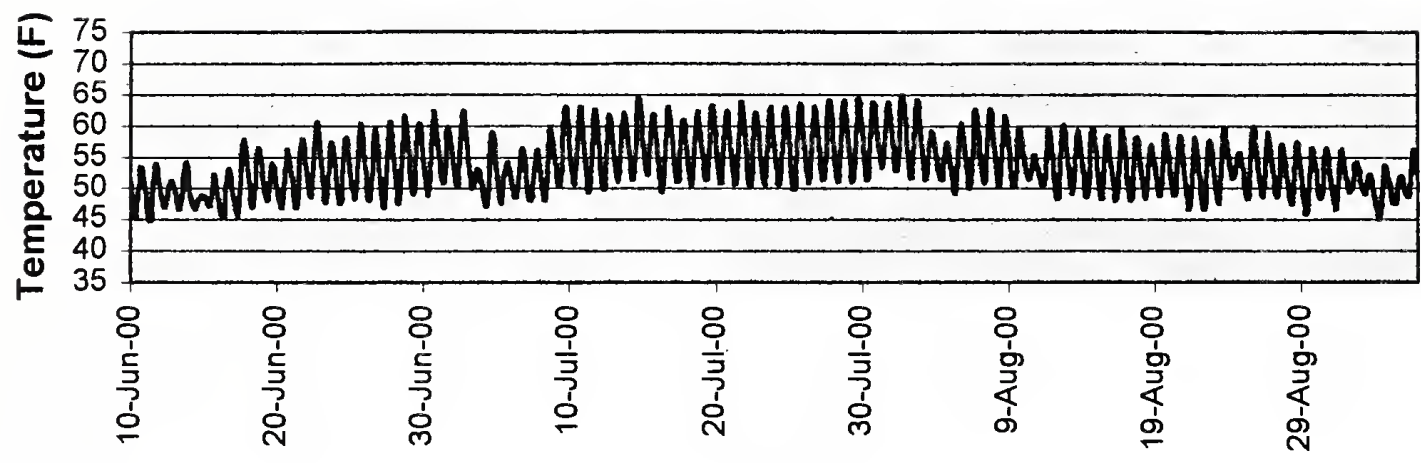

Date

\begin{tabular}{lcccc} 
Month & June & July & August & September \\
\hline Monthly Mean & 51.8 & 55.8 & 53.9 & 50.5 \\
Monthly Max & 62.4 & 64.4 & 65 & 56.1 \\
Monthly Min & 44.7 & 47.2 & 45.8 & 45 \\
Stdev & 4.1 & 4.4 & 3.9 & 2.4
\end{tabular}

\section{Blackfoot Above Landers Fork}

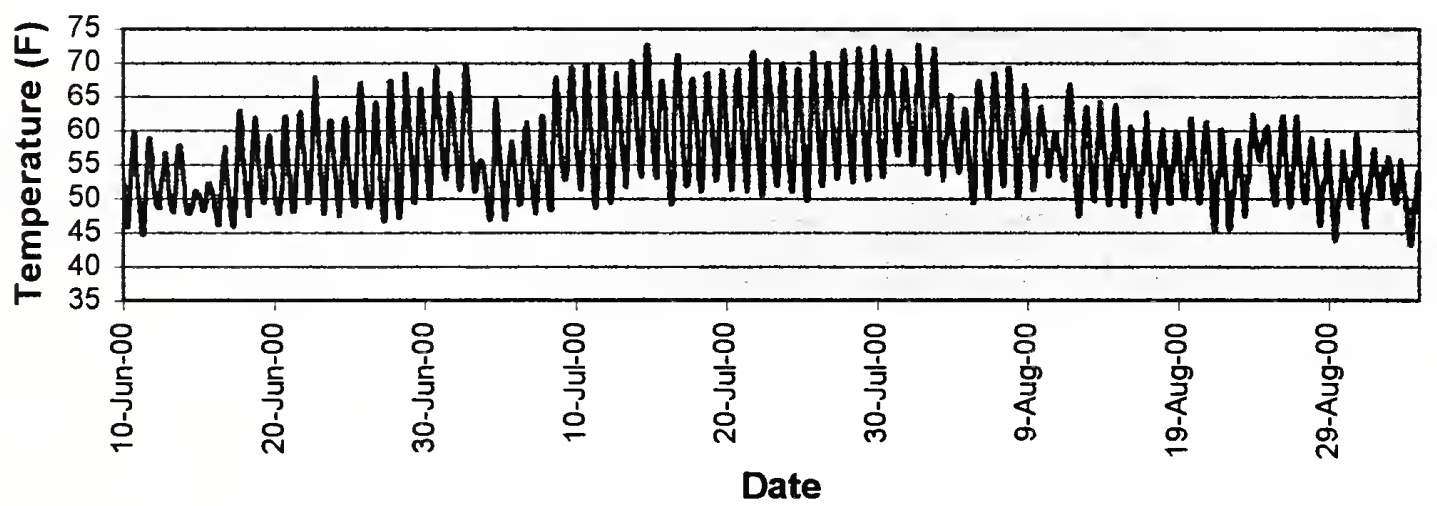

\begin{tabular}{lcccc} 
Month & June & July & August & September \\
\hline Monthly Mean & 54.2 & 59.5 & 56.1 & 51.3 \\
Monthly Max & 69.3 & 72.6 & 72.6 & 56.7 \\
Monthly Min & 44.7 & 46.9 & 43.9 & 43.3 \\
Stdev & 5.6 & 6.5 & 5.4 & 3.3
\end{tabular}




\section{Blackfoot River at Raymond Bridge}

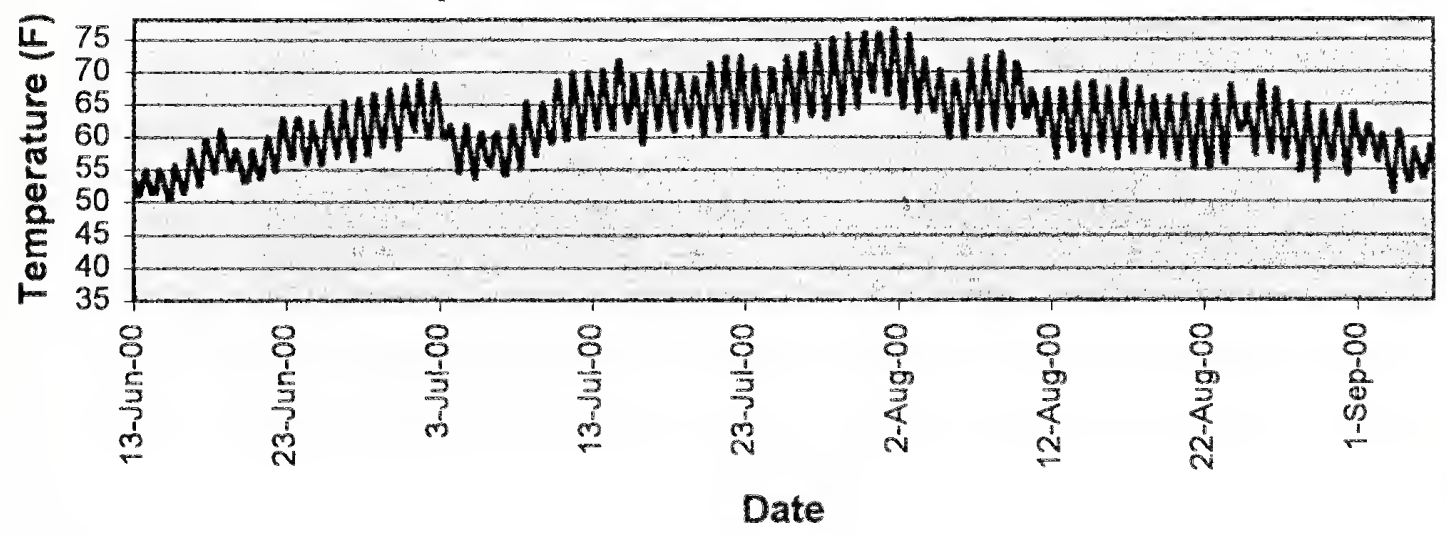

\begin{tabular}{lrrrc} 
Month & June & July & August & September \\
\hline Monthly Mean & 58 & 64.8 & 63.4 & 56.7 \\
Monthly Max & 67.9 & $1994 \sqrt{76}$ & 76.6 & 61.8 \\
& & $5.0^{\circ}$ & 5.5 & \\
Monthly Min & 50.3 & 53.6 & 53.1 & 51.4 \\
Stdev & 4.1 & 4.9 & 4.5 & 2.7
\end{tabular}

Blackfoot River at Cutoff Bridge

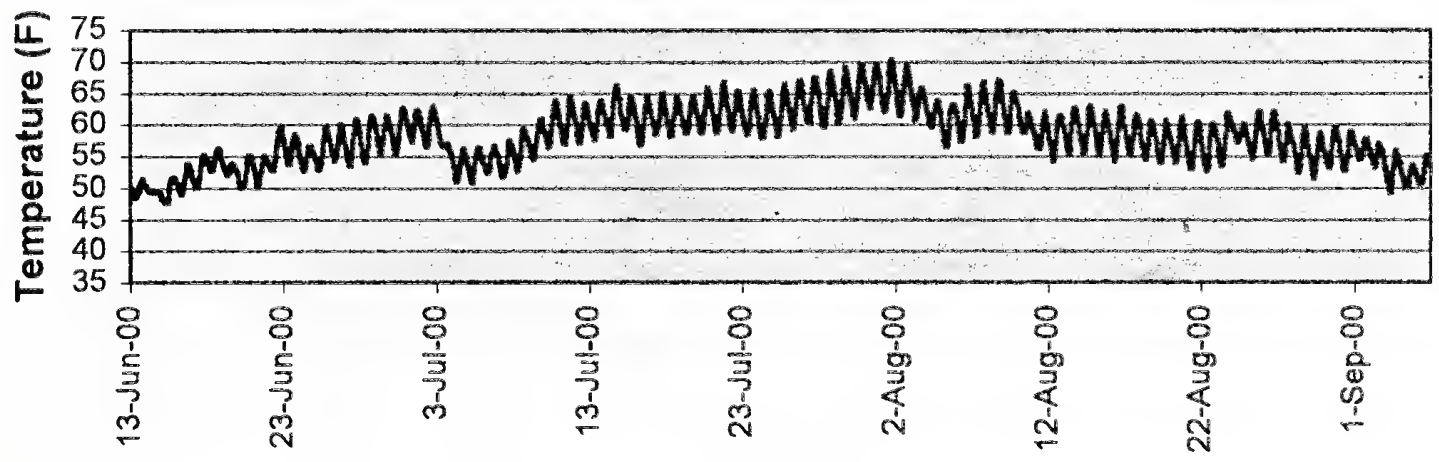

Date

\begin{tabular}{|c|c|c|c|c|c|}
\hline Month & June & & July & August & September \\
\hline Monthly Mean & 54.3 & & 60.5 & 59.3 & 53.4 \\
\hline Monthly Max & 62.7 & $\underset{19 G 9}{J}$ & $\begin{array}{l}69.7 \\
5.3\end{array}$ & $\begin{array}{l}70.3 \\
5 . ?\end{array}$ & 57.9 \\
\hline Monthly Min & 47.5 & & 50.6 & 51.4 & 49.2 \\
\hline Stdev & 3.6 & & 4 & 3.6 & 2.3 \\
\hline
\end{tabular}




\section{Blackfoot River at Corrick River Bend}

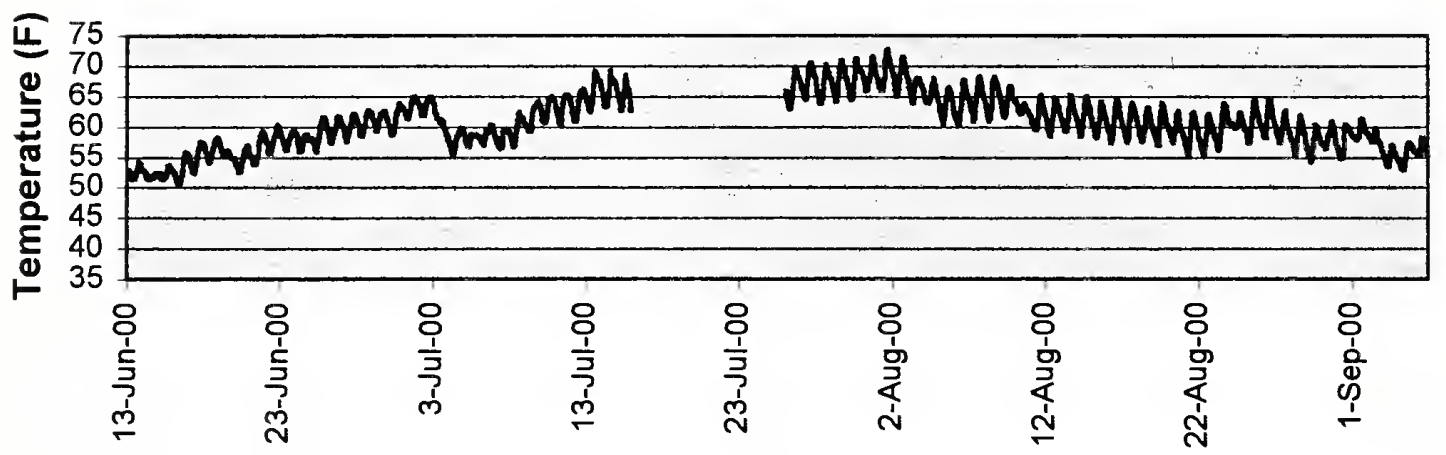

Date

\begin{tabular}{lcccc} 
Month & June & July & August & September \\
\hline Monthly Mean & 56.8 & 63.5 & 61.8 & 56.5 \\
Monthly Max & 63.8 & 71.5 & 72.7 & 61.3 \\
Monthly Min & 50.6 & 55.3 & 54.2 & 52.9 \\
Stdev & 3.4 & 3.9 & 3.5 & 2.1
\end{tabular}

Blackfoot River at Scotty Brown Bridge

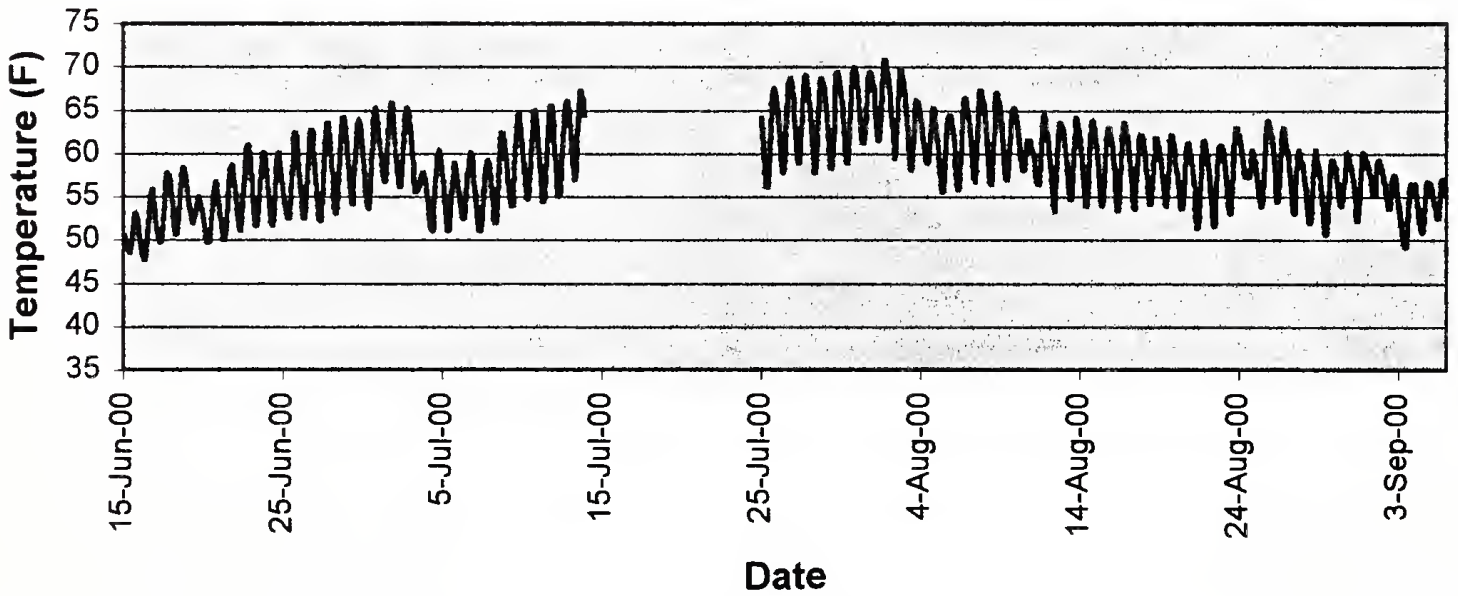

\begin{tabular}{lcccc}
\multicolumn{1}{c}{ Month } & June & July & August & September \\
\hline Monthly Mean & 55.6 & 60.5 & 59.6 & 54.8 \\
Monthly Max & 65.3 & 69.9 & 70.8 & 59.2 \\
Monthly Min & 47.8 & 51.1 & 50.6 & 49.2 \\
Stdev & 4.1 & 4.8 & 3.9 & 2.5
\end{tabular}




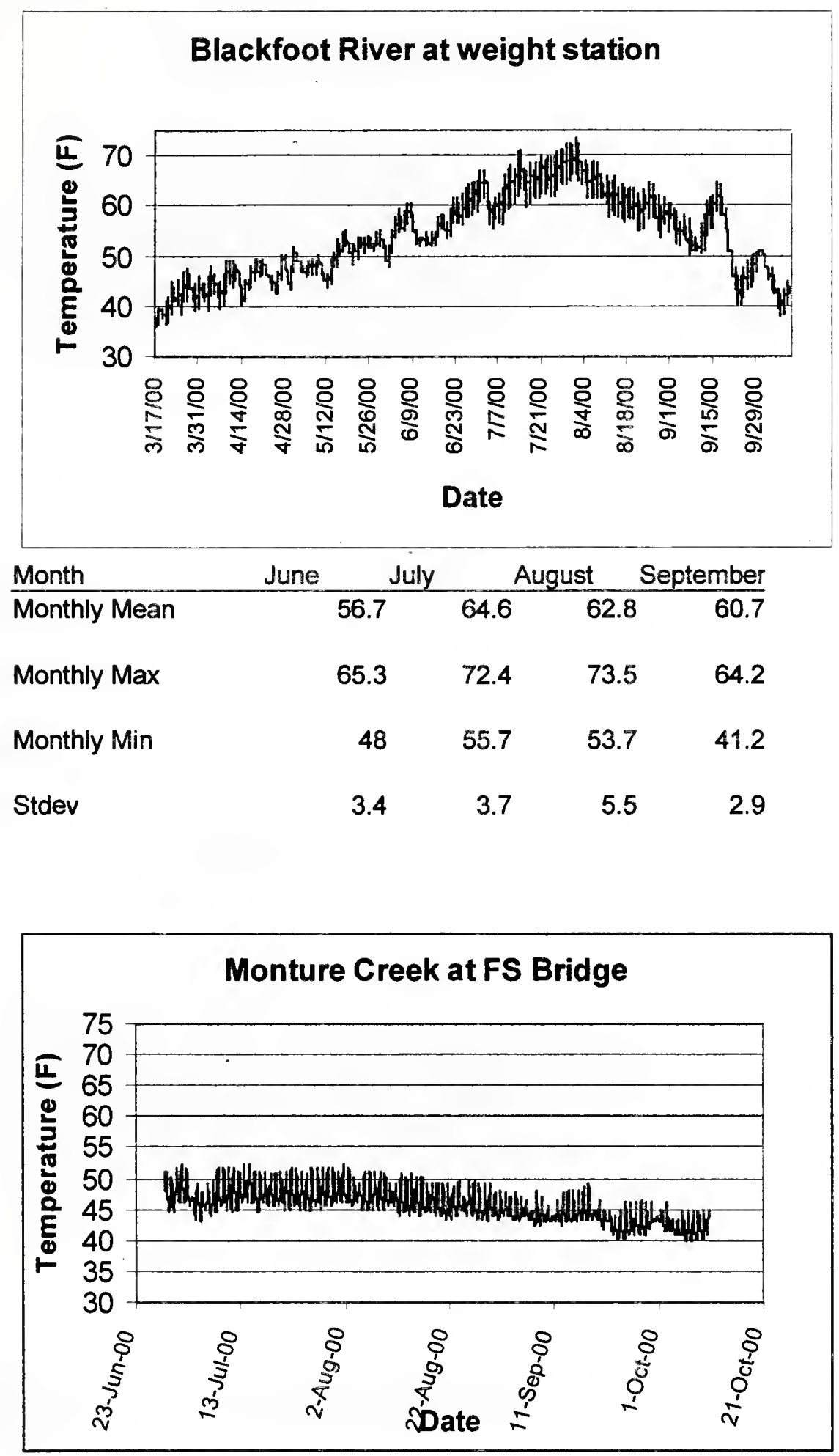




\section{Belmont Creek near Mouth}

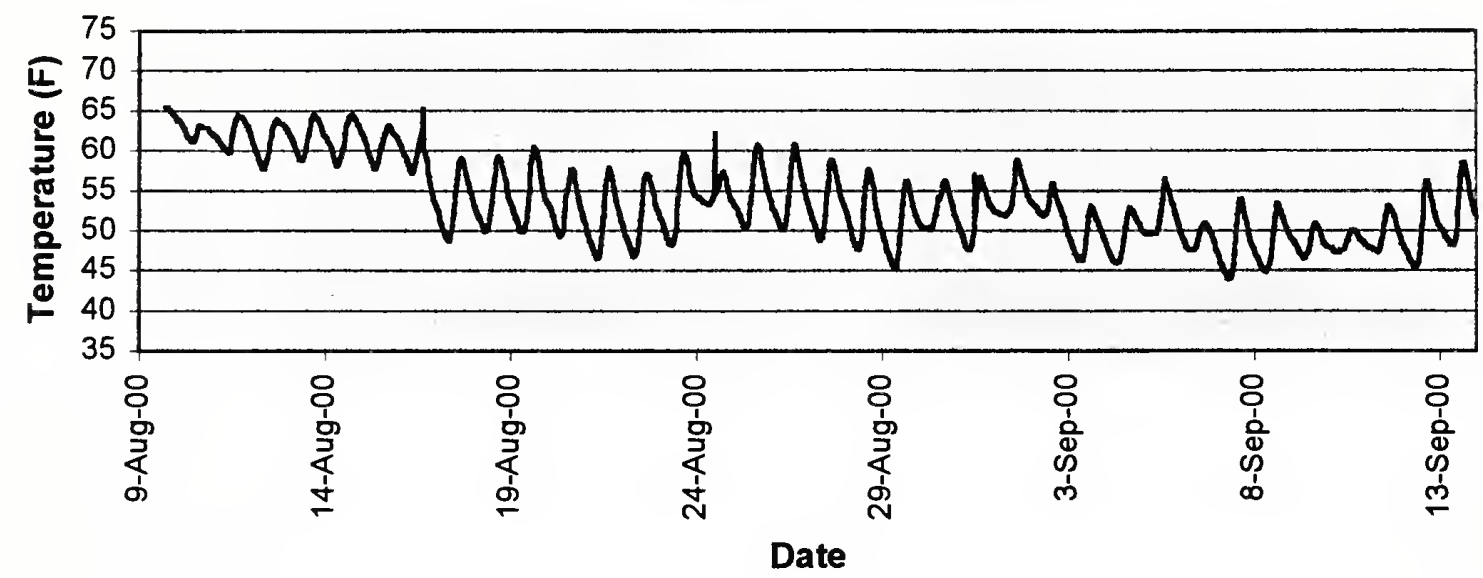

\begin{tabular}{|c|c|c|c|c|}
\hline Month & June & July & August & September \\
\hline Monthly Mean & & & 55.9 & 50.2 \\
\hline Monthly Max & & & 65.5 & 58.8 \\
\hline Monthly Min & & & 45.5 & 44 \\
\hline Stdev & & & 5 & 3.1 \\
\hline
\end{tabular}

\section{Monture Creek Below Fishing Access Site}

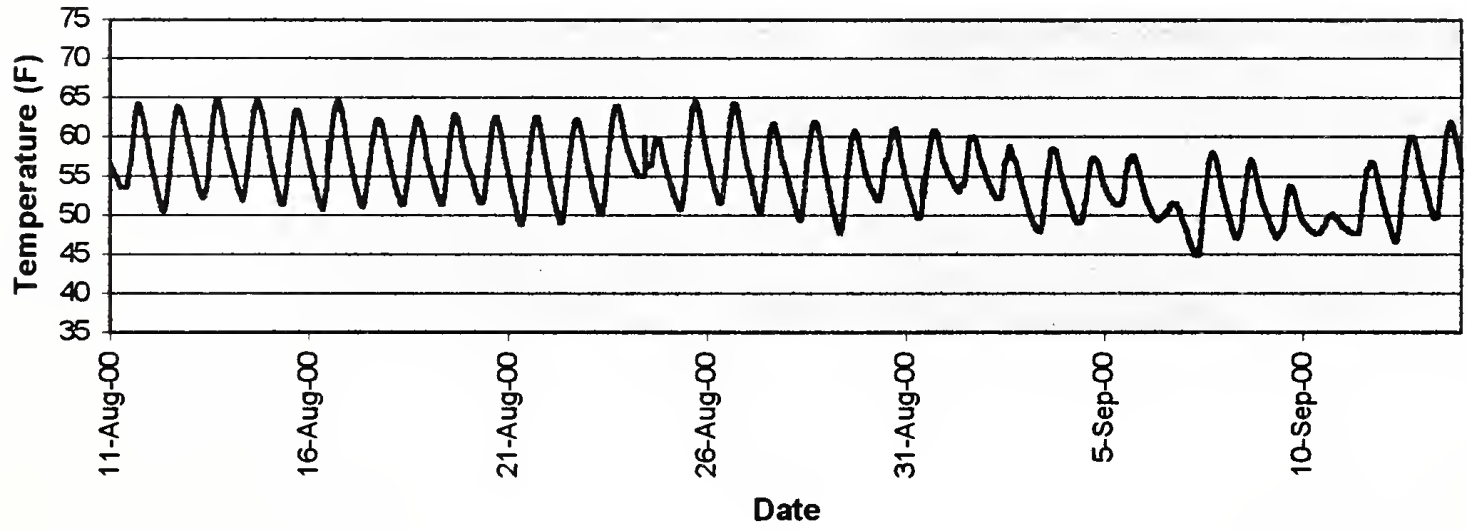

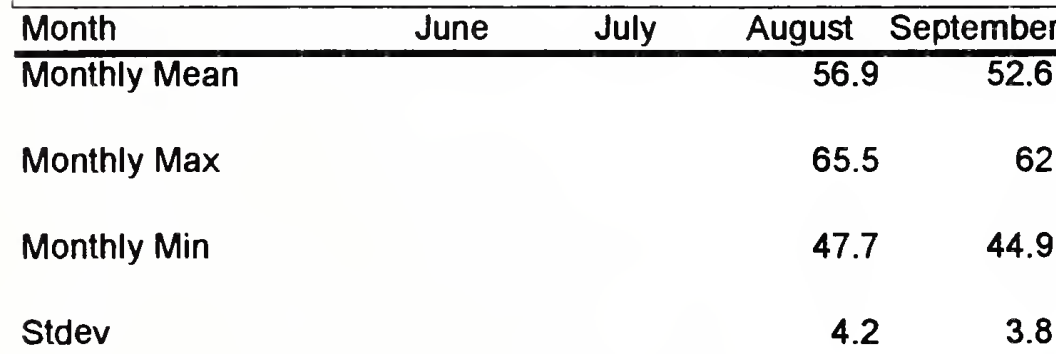




\section{Chamberlain Creek near Mouth}

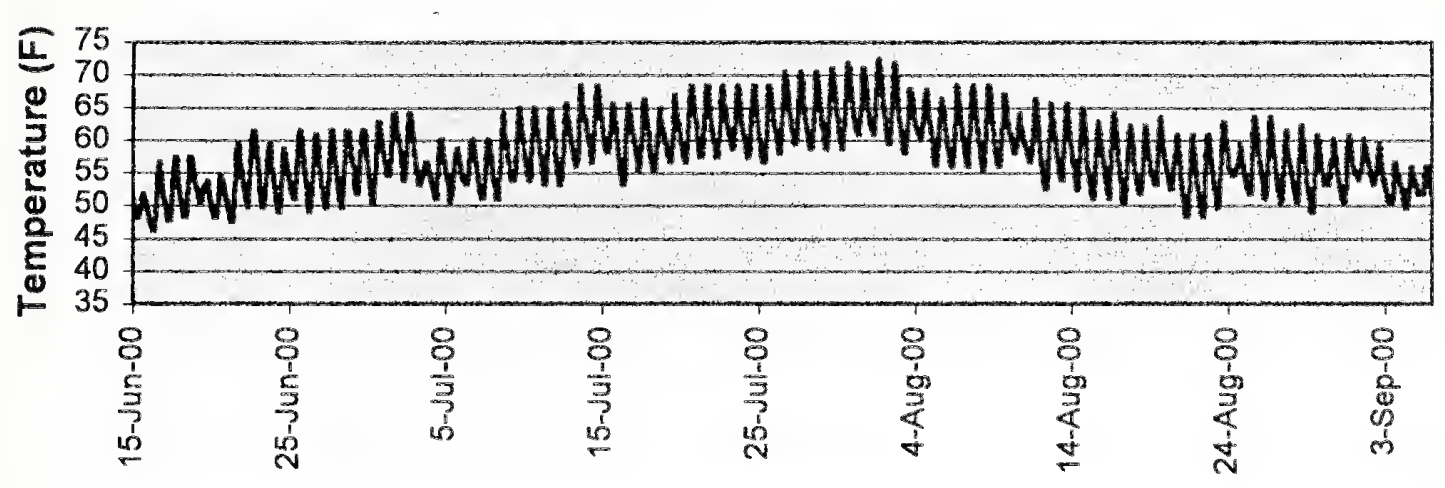

Date

\begin{tabular}{lcccc} 
Month & June & July & August & September \\
\hline Monthly Mean & 53.8 & 60.4 & 58.3 & 53.8 \\
Monthly Max & 62.8 & 71.8 & 72.5 & 60.1 \\
Monthly Min & 46.1 & 50.4 & 48.3 & 49.7 \\
Stdev & 4.1 & 4.7 & 4.8 & 2.5
\end{tabular}

\section{East Fork of Chamberlain Creek}

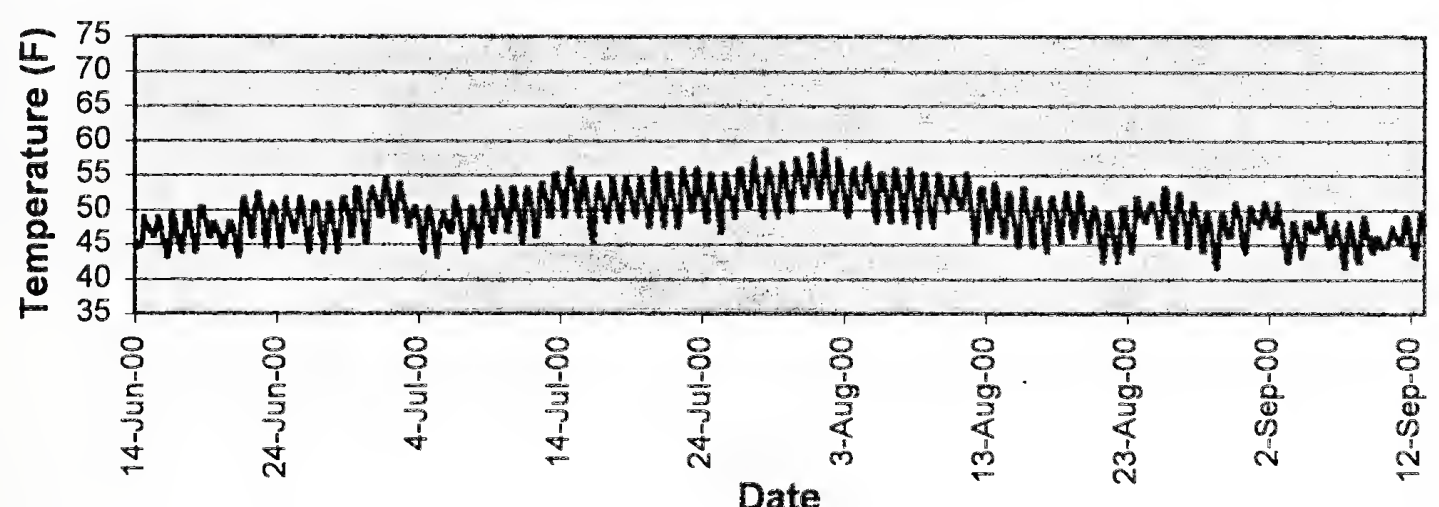

\begin{tabular}{lcccc} 
Month & June & July & August & September \\
\hline Monthly Mean & 47.9 & 51.1 & 50 & 46.6 \\
Monthly Max & 53.2 & 58 & 58.7 & 51.1 \\
Monthly Min & 43.2 & 43.2 & 41.7 & 41.7 \\
Stdev & 2.4 & 3 & 3.3 & 2.1
\end{tabular}




\section{West Fork Of Chamberlain Creek}

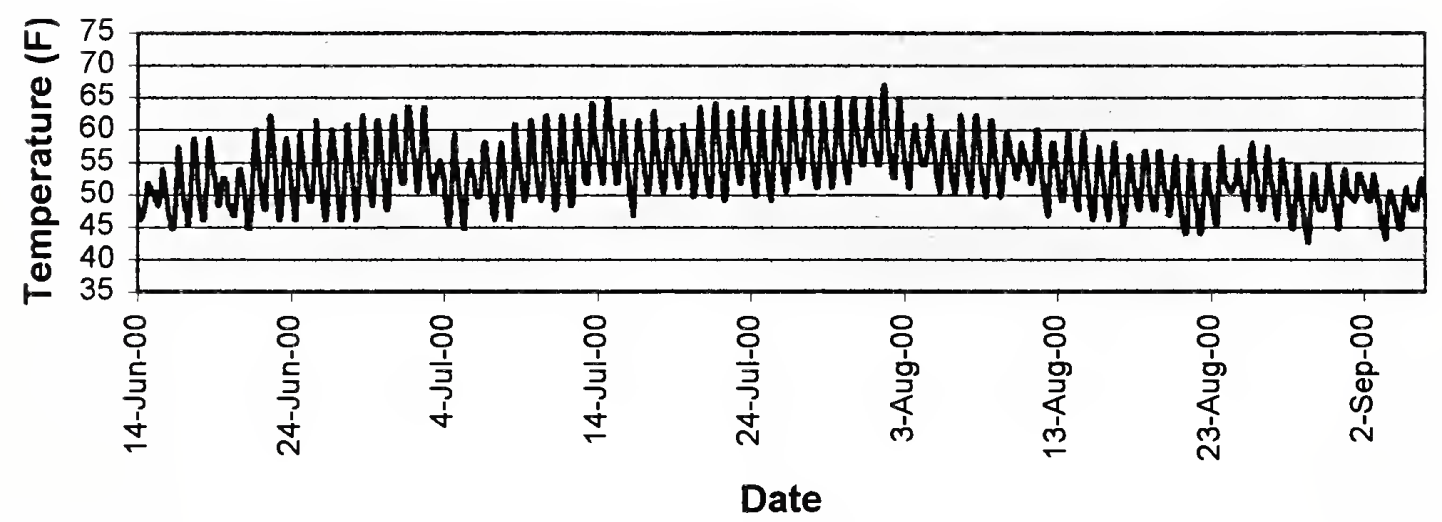

\begin{tabular}{lcccc} 
Month & June & July & August & September \\
\hline Monthly Mean & 52.2 & 55.4 & 52.8 & 48.9 \\
Monthly Max & 62.2 & 64.9 & 67 & 53.2 \\
Monthly Min & 44.7 & 44.7 & 42.5 & 43.2 \\
Stdev & 4.6 & 4.6 & 4.4 & 2.3
\end{tabular}

\section{Chamberlain Creek above West Fork}

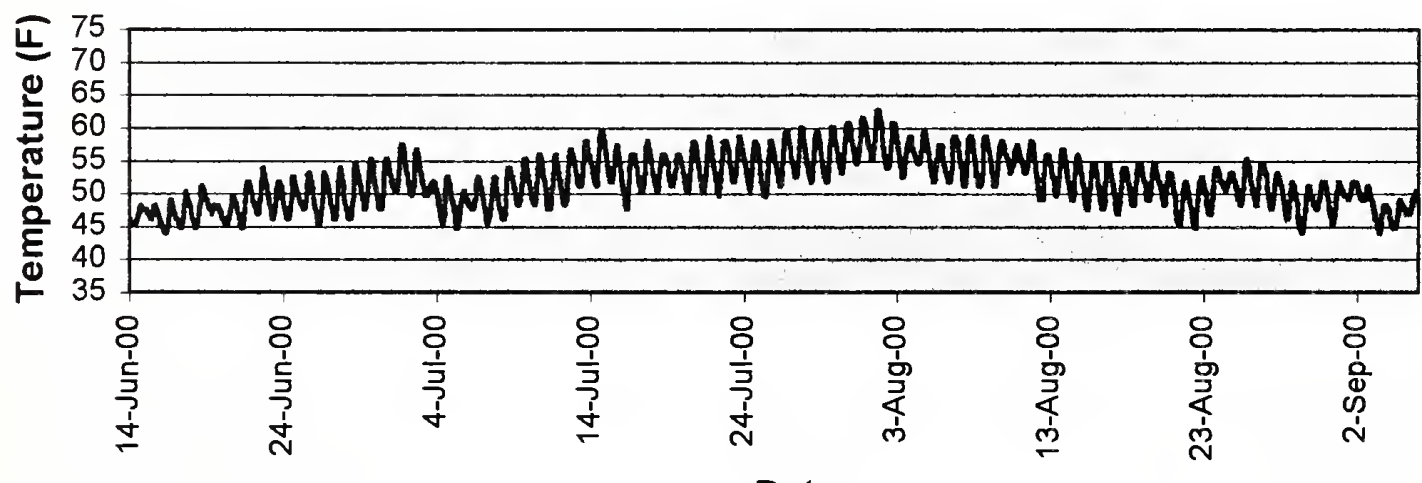

Date

\begin{tabular}{lcccc} 
Month & June & July & August & September \\
\hline Monthly Mean & 48.6 & 53.3 & 52.6 & 48.2 \\
Monthly Max & 55.3 & 61.5 & 62.8 & 51.8 \\
Monthly Min & 43.9 & 44.7 & 43.9 & 43.9 \\
Stdev & 2.6 & 3.5 & 3.6 & 2
\end{tabular}




\section{Clearwater River above Hwy. 200}

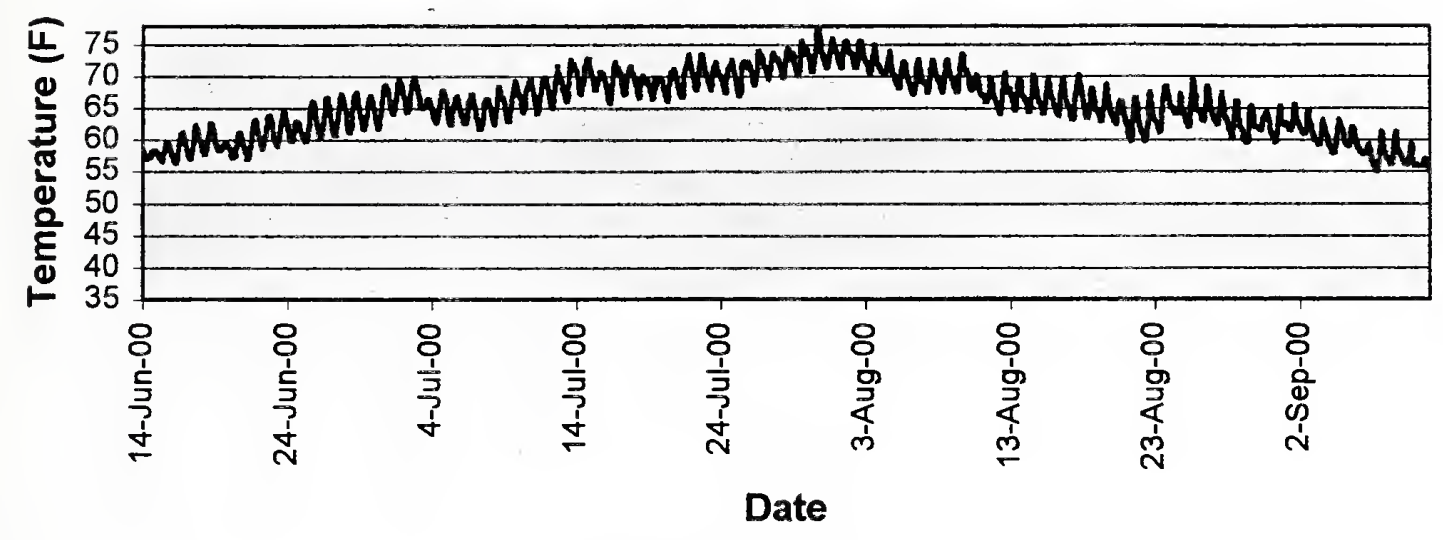

\begin{tabular}{lcrrc} 
Month & June & July & August & September \\
\hline Monthly Mean & 61.2 & 68.9 & 66.8 & 59.1 \\
Monthly Max & 68.7 & 77.6 & 75.7 & 65.5 \\
Monthly Min & 56.4 & 61.8 & 59.5 & 54.7 \\
Stdev & 3 & 3.2 & 3.7 & 2.6
\end{tabular}

Cottonwood Creek above Douglas $\mathrm{Cr}$.

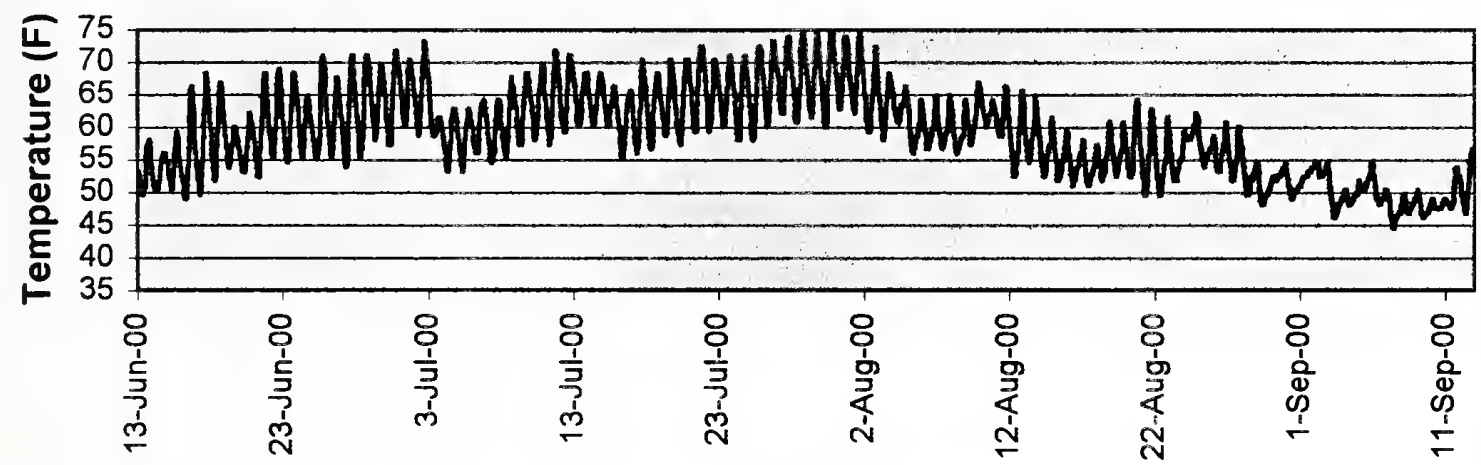

Date

\begin{tabular}{lcccc} 
Month & June & July & August & September \\
\hline Monthly Mean & 59.5 & 64.1 & 57.6 & 50.2 \\
Monthly Max & 71.8 & 74.5 & 74.5 & 58.7 \\
Monthly Min & 49 & 53.2 & 48.3 & 44.7 \\
Stdev & 5.8 & 4.9 & 4.9 & 2.9
\end{tabular}




\section{Cottonwood Creek above Pole Cr.}

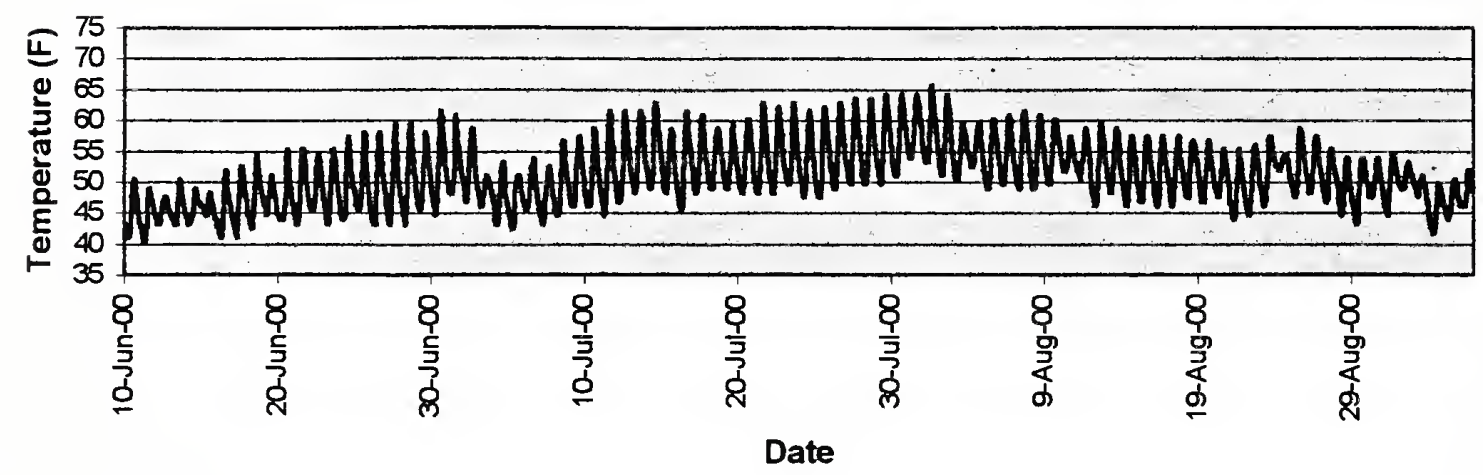

\begin{tabular}{lcccc} 
Month & June & July & August & September \\
\hline Monthly Mean & 47.9 & 52.8 & 52.6 & 48.2 \\
Monthly Max & 61.5 & 64.2 & 65.6 & 53.2 \\
Monthly Min & 40.2 & 42.5 & 43.2 & 41.7 \\
Stdev & 4.4 & 5 & 4.1 & 2.7
\end{tabular}

\section{Douglas Creek above Cottonwood Cr.}

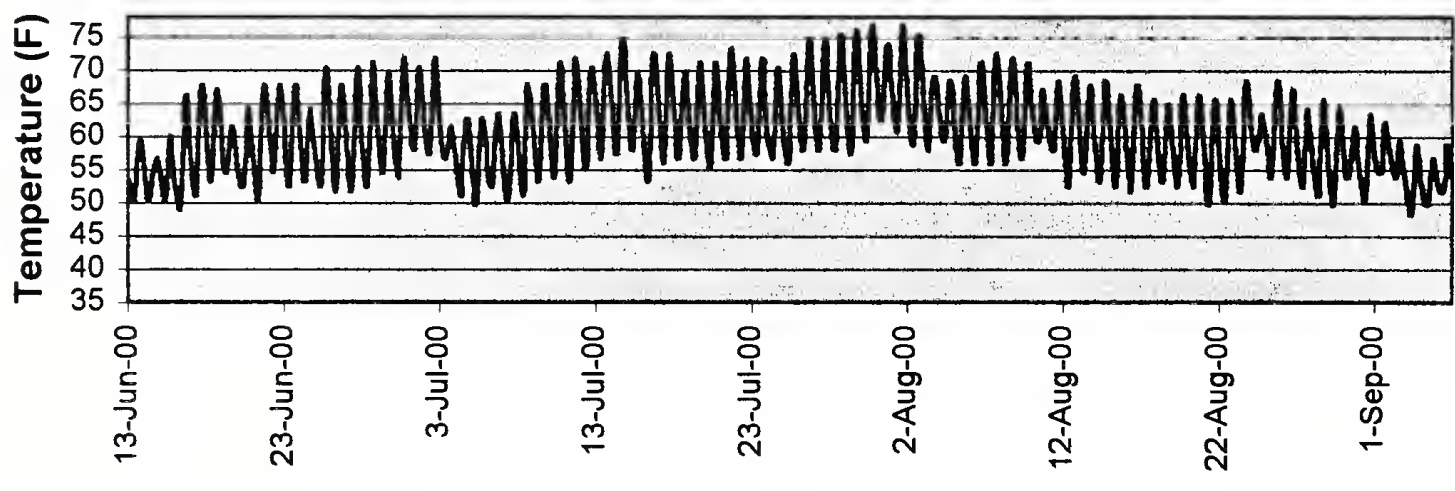

Date

\begin{tabular}{lcccc} 
Month & June & July & August & September \\
\hline Monthly Mean & 58.9 & 62.9 & 60.8 & 54.3 \\
Monthly Max & 71.8 & 76.7 & 76.7 & 62.2 \\
Monthly Min & 49 & 49.7 & 49.7 & 48.3 \\
Stdev & 5.7 & 6 & 5.5 & 3.2
\end{tabular}




\section{Douglas Creek at Mouth of Chimney Creek}

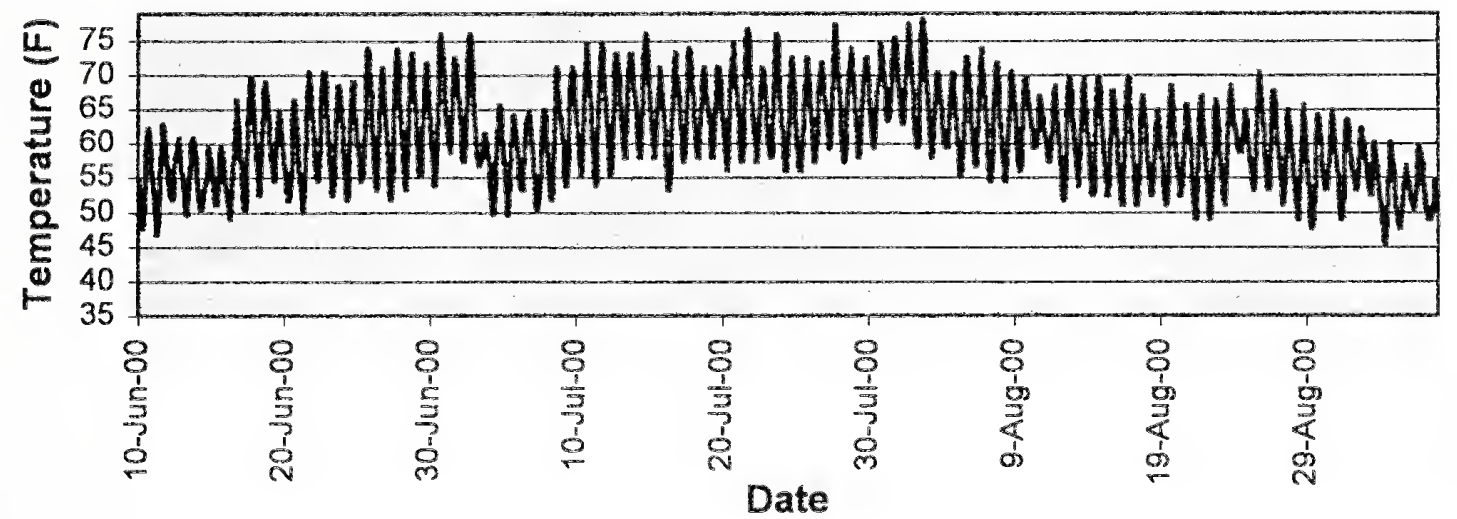

\begin{tabular}{lcccc} 
Month & June & July & August & September \\
\hline Monthly Mean & 59.5 & 64 & 60.9 & 53.6 \\
Monthly Max & 76 & 77.4 & 78.1 & 62.2 \\
Monthly Min & 46.8 & 49.7 & 47.6 & 44.7 \\
Stdev & 6.5 & 6.2 & 6.1 & 4.1
\end{tabular}

\section{Elk Creek near Mouth}

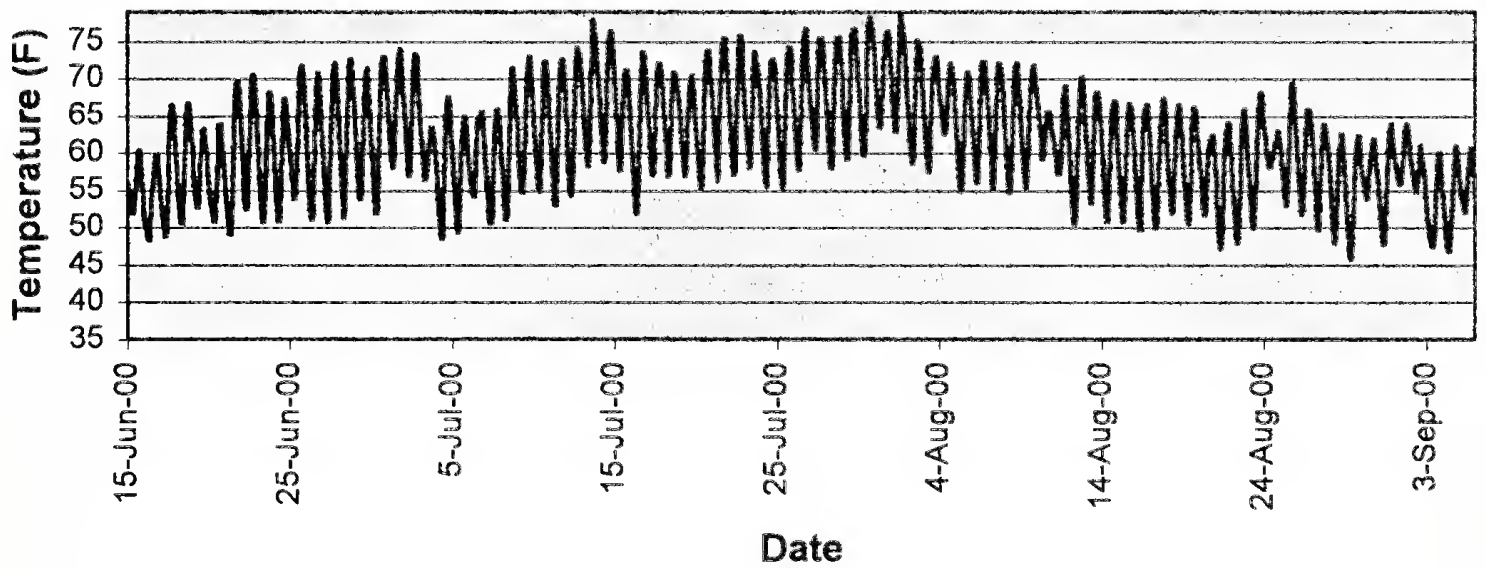

\begin{tabular}{lcccc} 
Month & June & July & August & September \\
\hline Monthly Mean & 59.7 & 65 & 61.1 & 55.3 \\
Monthly Max & 72.9 & 78.2 & 78.5 & 63.8 \\
Monthly Min & 48.3 & 48.6 & 45.8 & 46.9 \\
Stdev & 6.7 & 6.8 & 6.5 & 4.5
\end{tabular}




\section{Elk Creek at Hwy. 200}

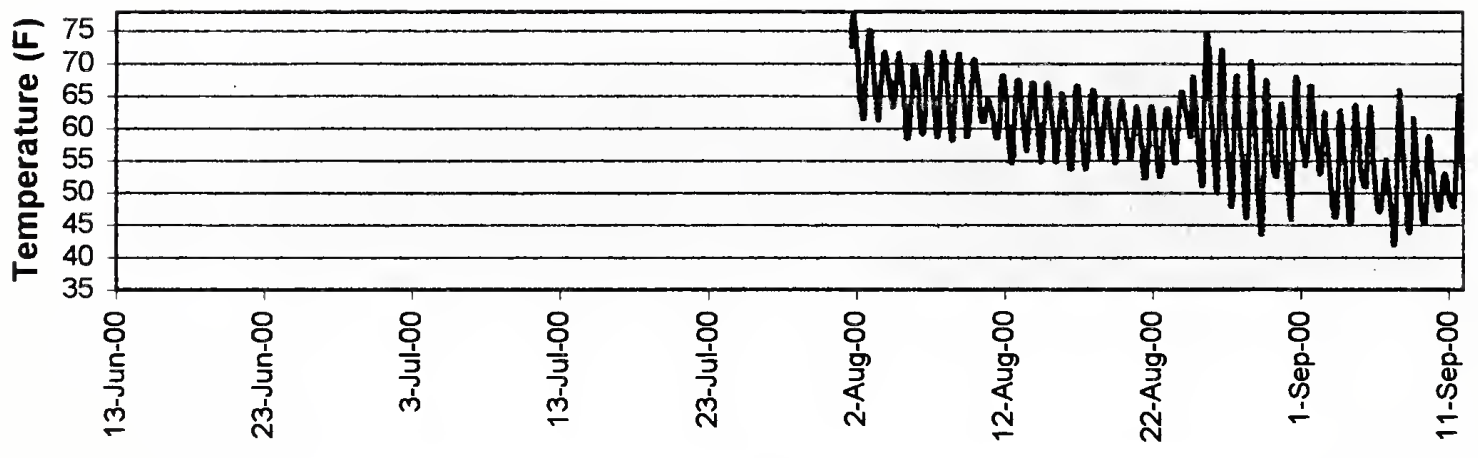

Date

\begin{tabular}{|c|c|c|c|}
\hline Month & July & August & September \\
\hline Monthly Mean & & 61.8 & 53.7 \\
\hline Monthly Max & & 77.6 & 67.6 \\
\hline Monthly Min & & 43.6 & 42 \\
\hline Stdev & & 6 & 6.1 \\
\hline
\end{tabular}

Elk Creek at Sunset Hill Road

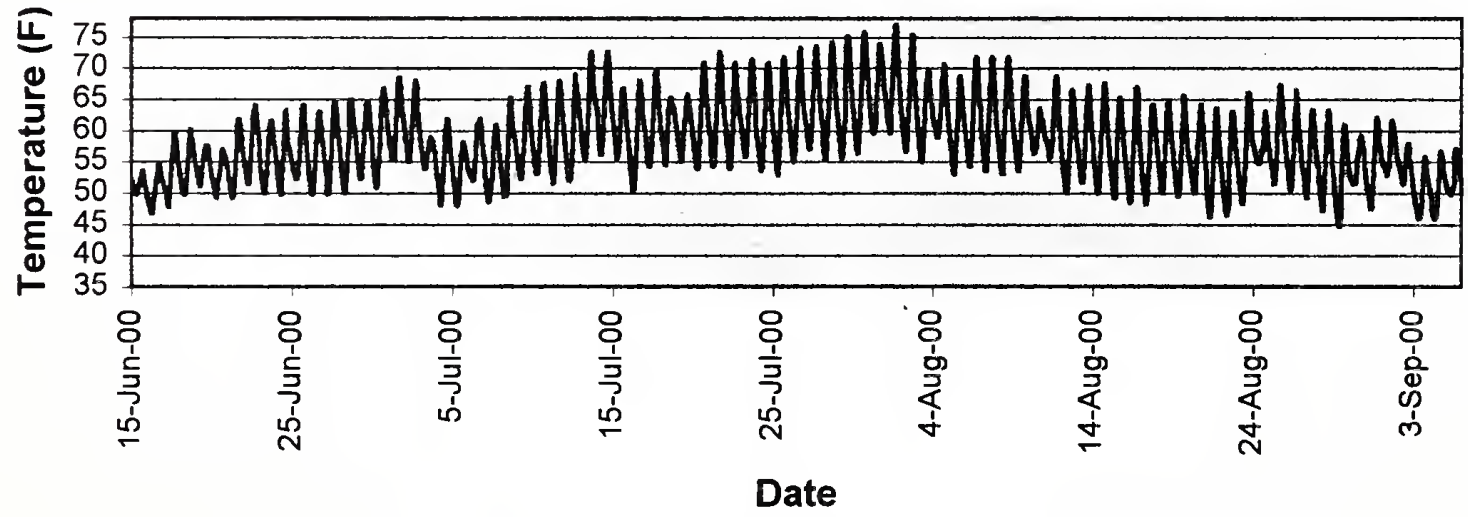

\begin{tabular}{lcccc} 
Month & June & July & August & September \\
\hline Monthly Mean & 55.1 & 60.6 & 58.4 & 52.4 \\
Monthly Max & 66.7 & 75.7 & 76.9 & 61.5 \\
Monthly Min & 46.7 & 48 & 44.7 & 45.8 \\
Stdev & 4.6 & 6 & 6.1 & 3.7
\end{tabular}


Lower Gold Creek

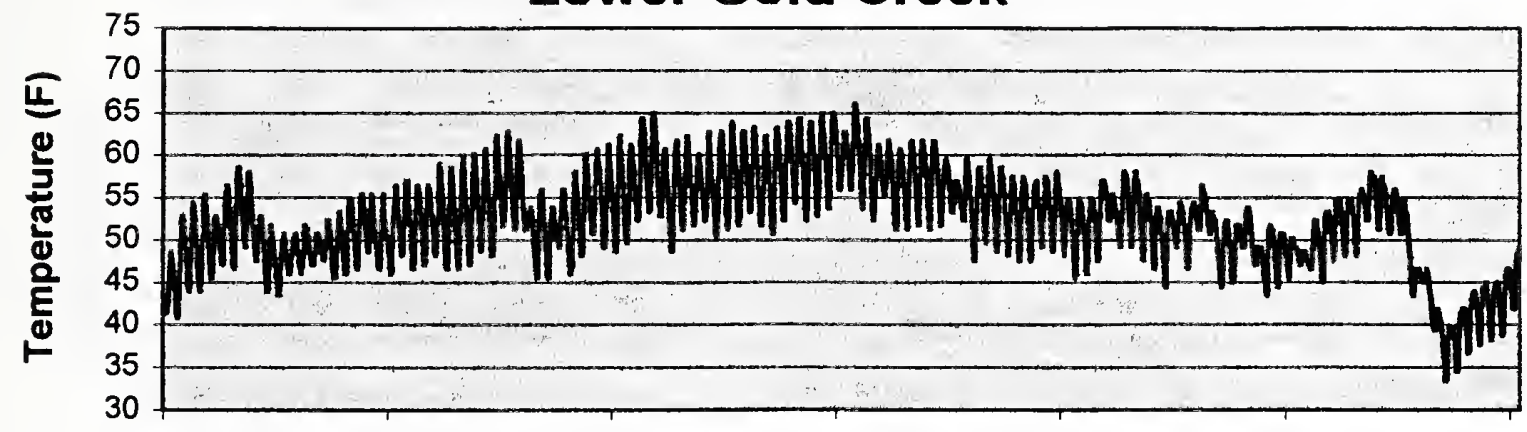

\section{Date}

\begin{tabular}{lcccc} 
Month & June & July & August & September \\
\hline Monthly Mean & 50.7 & 56.3 & 54.5 & 48 \\
Monthly Max & 62.3 & 64.9 & 66 & 58 \\
Monthly Min & 40.9 & 45.6 & 44.5 & 33.4 \\
Stdev & 4.1 & 4.5 & 4 & 2.3
\end{tabular}




\section{McElwain Creek at Ovando-Helmville Road}
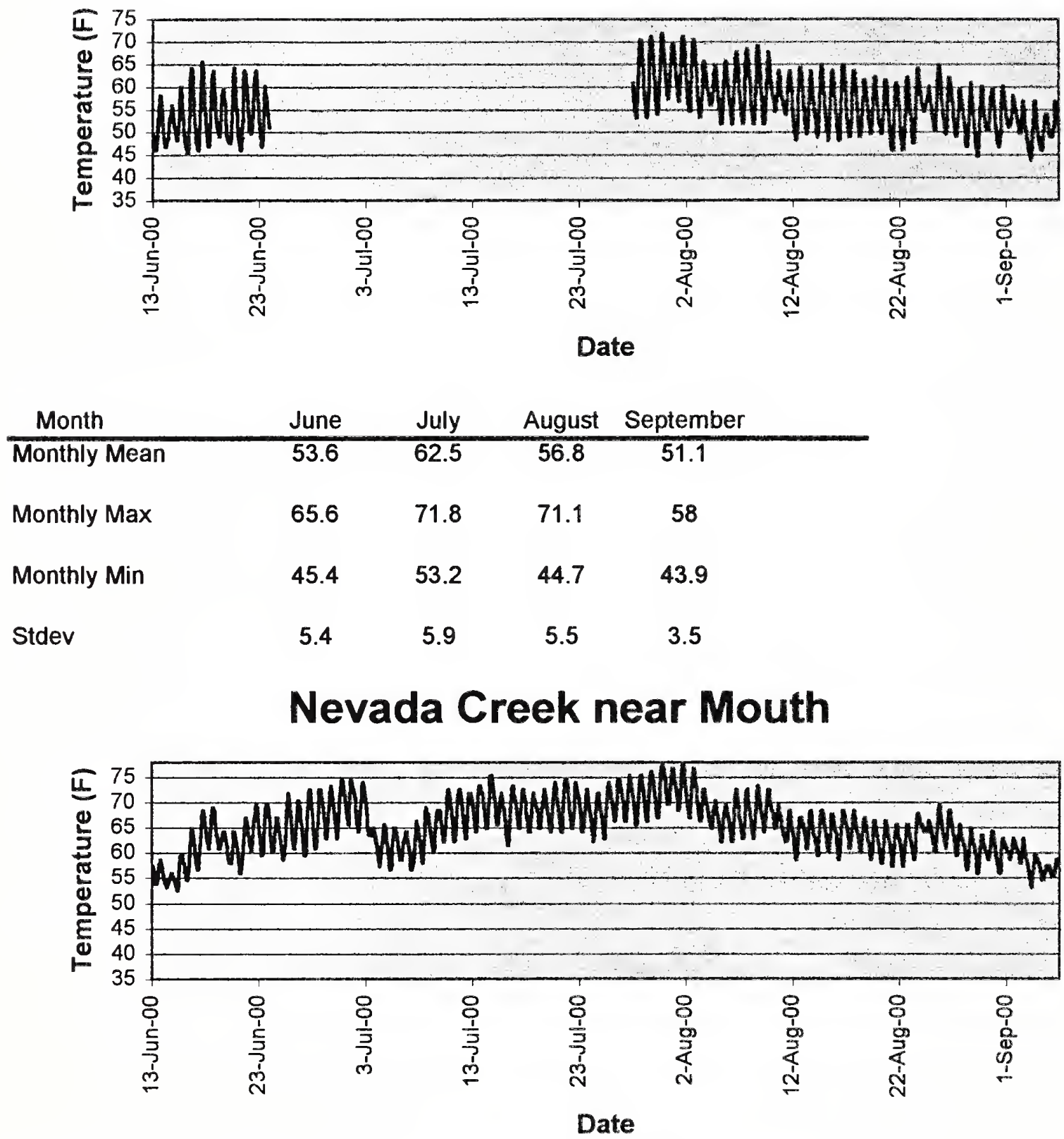

\begin{tabular}{lcccc} 
Month & June & July & August & September \\
\hline Monthly Mean & 63 & 67.9 & 64.8 & 57.8 \\
Monthly Max & 74.6 & 77.4 & 77.4 & 62.8 \\
Monthly Min & 52.5 & 56.7 & 56 & 53.2 \\
Stdev & 5.3 & 4.5 & 4.1 & 2.5
\end{tabular}




\section{Nevada Creek above Nevada Spring Cr.}

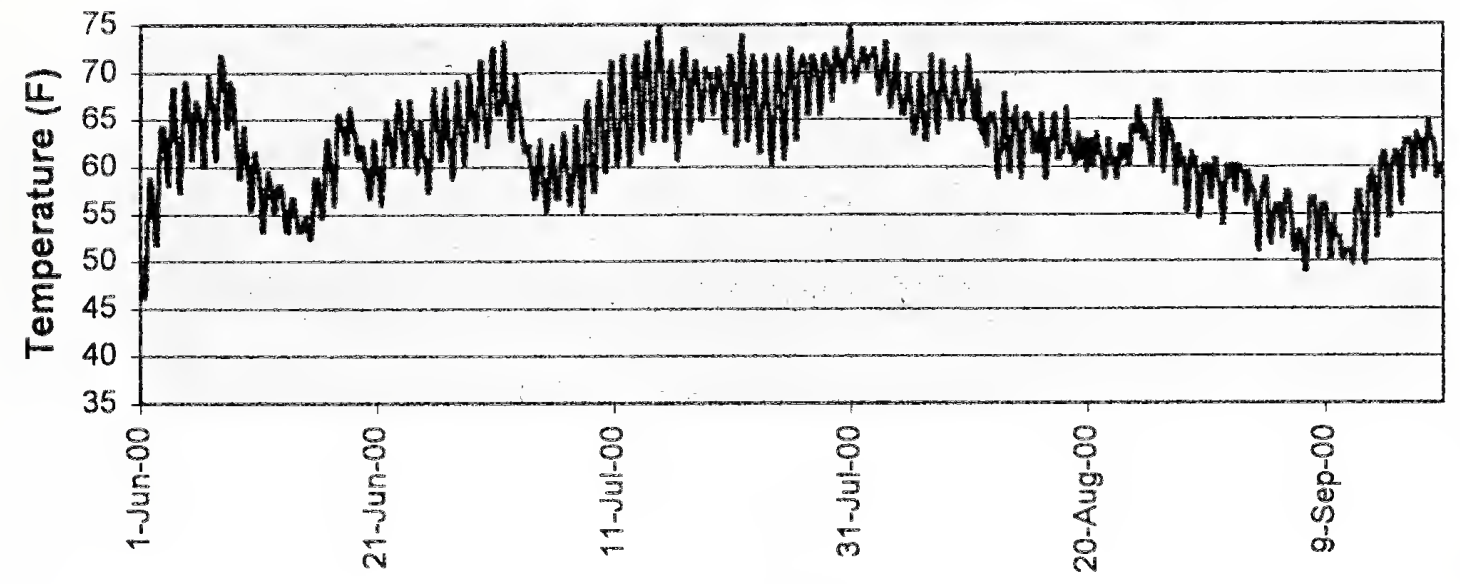

Date

\begin{tabular}{lcccc} 
Month & June & July & August & September \\
\hline Monthly Mean & 61.4 & 66.3 & 63.8 & 56.6 \\
Monthly Max & 72.5 & 74.5 & 73.2 & 64.9 \\
Monthly Min & 46.1 & 55.3 & 53.9 & 49 \\
Stdev & 4.9 & 4.6 & 3.9 & 3.8
\end{tabular}

\section{Nevada Creek below Reservoir}

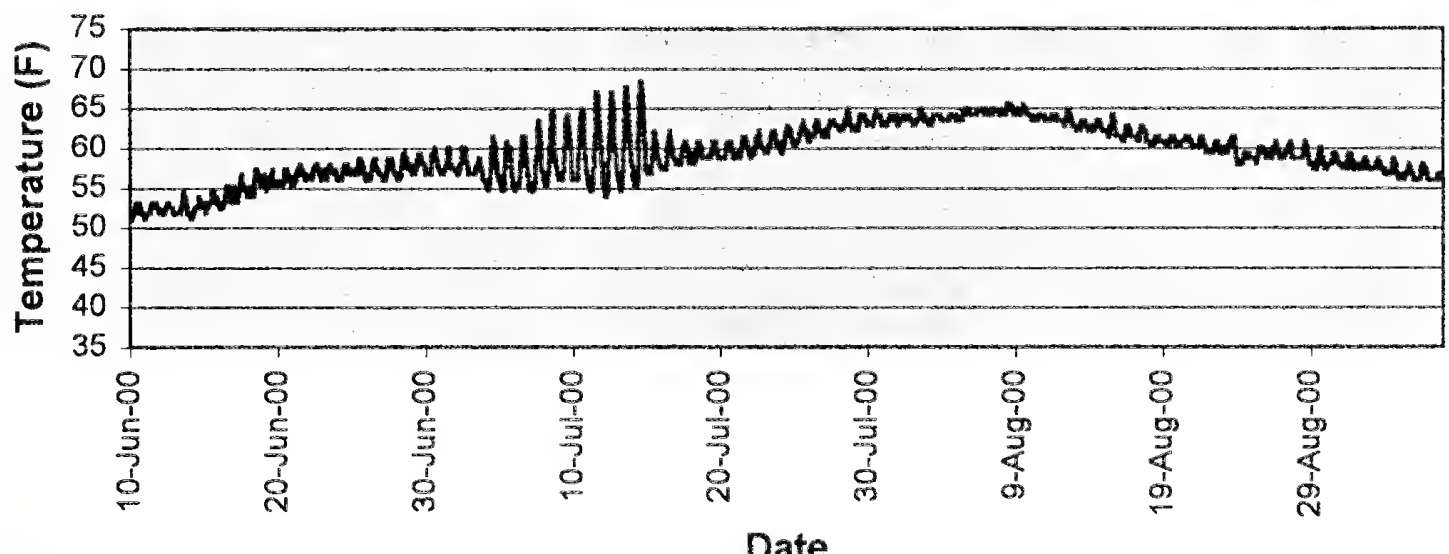

Date

\begin{tabular}{lcccc} 
Month & June & July & August & September \\
\hline Monthly Mean & 55.4 & 59.9 & 61.7 & 56.9 \\
Monthly Max & 60.1 & 68.4 & 65.6 & 58.7 \\
Monthly Min & 51.1 & 53.9 & 57.4 & 55.3 \\
Stdev & 2.3 & 2.9 & 2.3 & 0.9
\end{tabular}




\section{Nevada Creek above Reservoir}

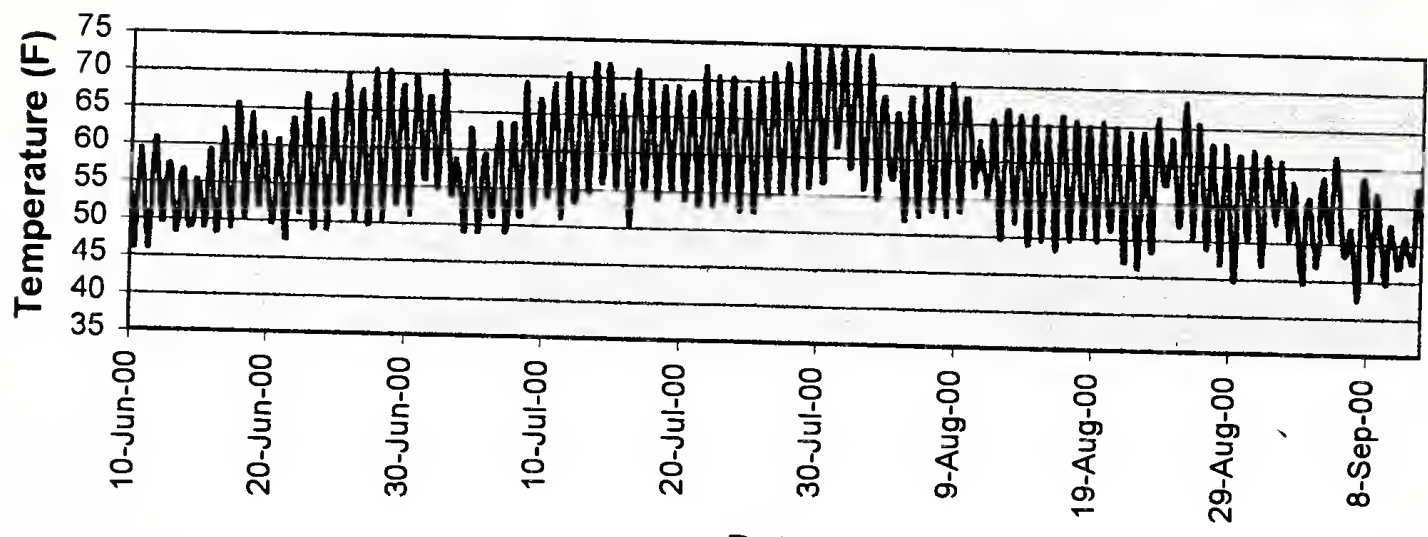

Date

\begin{tabular}{lcccc} 
Month & June & July & August & September \\
\hline Monthly Mean & 56.7 & 61.4 & 59 & 52.1 \\
Monthly Max & 70.4 & 74.5 & 74.5 & 61.5 \\
Monthly Min & 46.1 & 49 & 44.7 & 42.5 \\
Stdev & 5.9 & 6.1 & 5.9 & 4.3
\end{tabular}

Nevada Spring Creek near Mouth

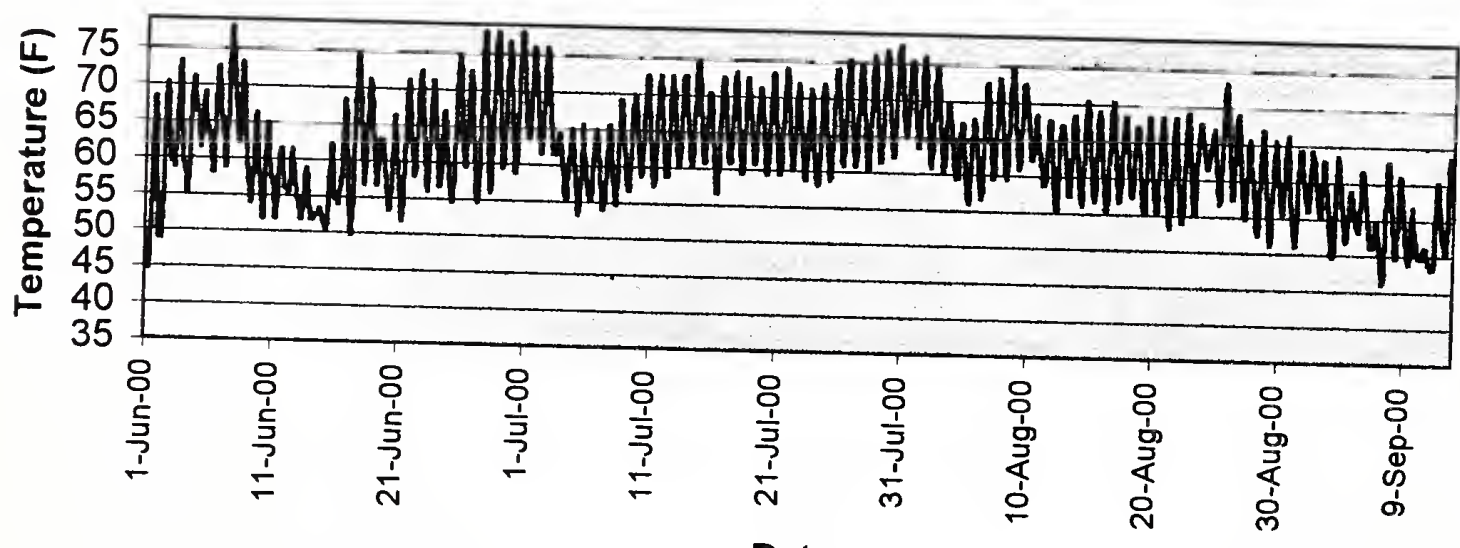

\section{Date}

\begin{tabular}{lcccc} 
Month & June & July & August & Septemb \\
\hline Monthly Mean & 61.7 & 65.3 & 62.9 & 55.4 \\
Monthly Max & 78 & 77.3 & 75.9 & 66.3 \\
Monthly Min & 44.7 & 53.2 & 51.1 & 46.1 \\
Stdev & 7 & 5.3 & 5 & 4.5
\end{tabular}




\section{Nevada Spring Creek at Coughlin's}

Fence

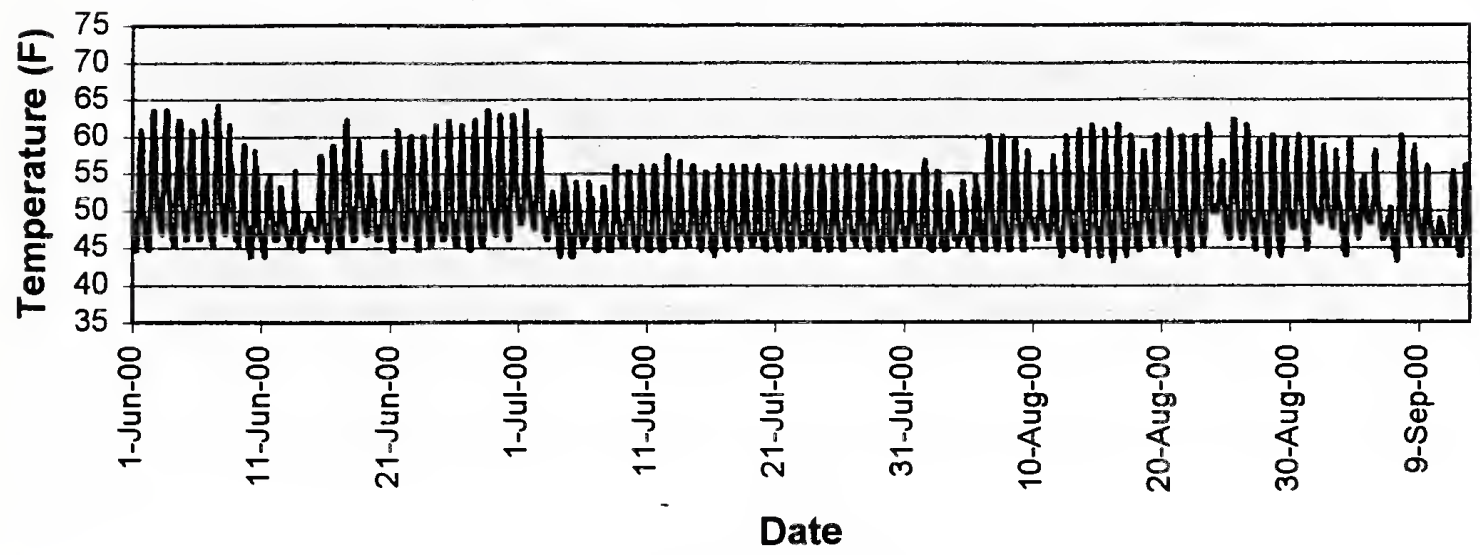

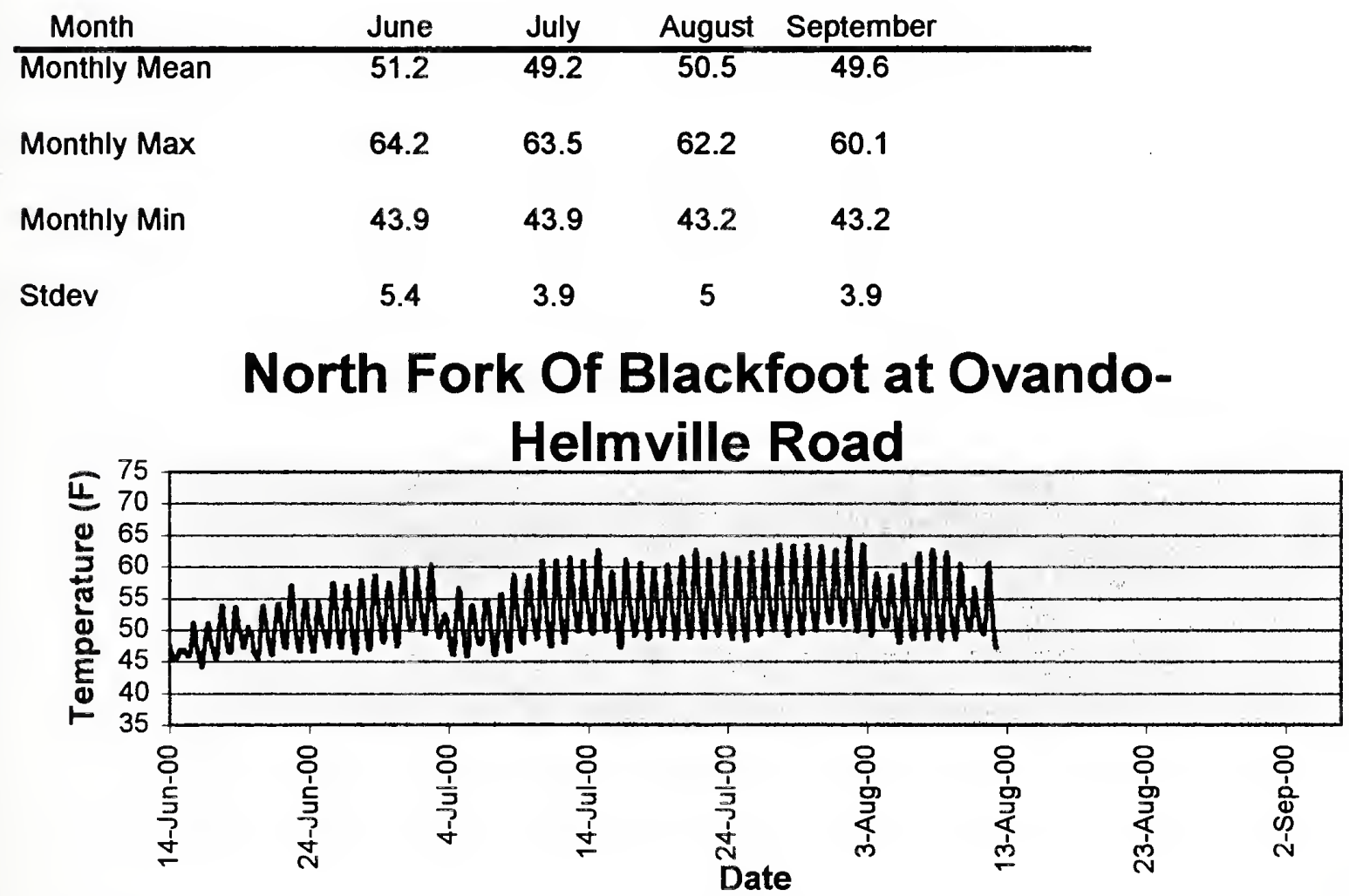

\begin{tabular}{|c|c|c|c|}
\hline Month & June & July & August \\
\hline Monthly Mean & 50.3 & 53.8 & 54.2 \\
\hline Monthly Max & 59.8 & 63.5 & 64.4 \\
\hline Monthly Min & 44.2 & 45.8 & 47.2 \\
\hline Stdev & 3.6 & 4.4 & 4.2 \\
\hline
\end{tabular}




\section{Wales Creek near Mouth}

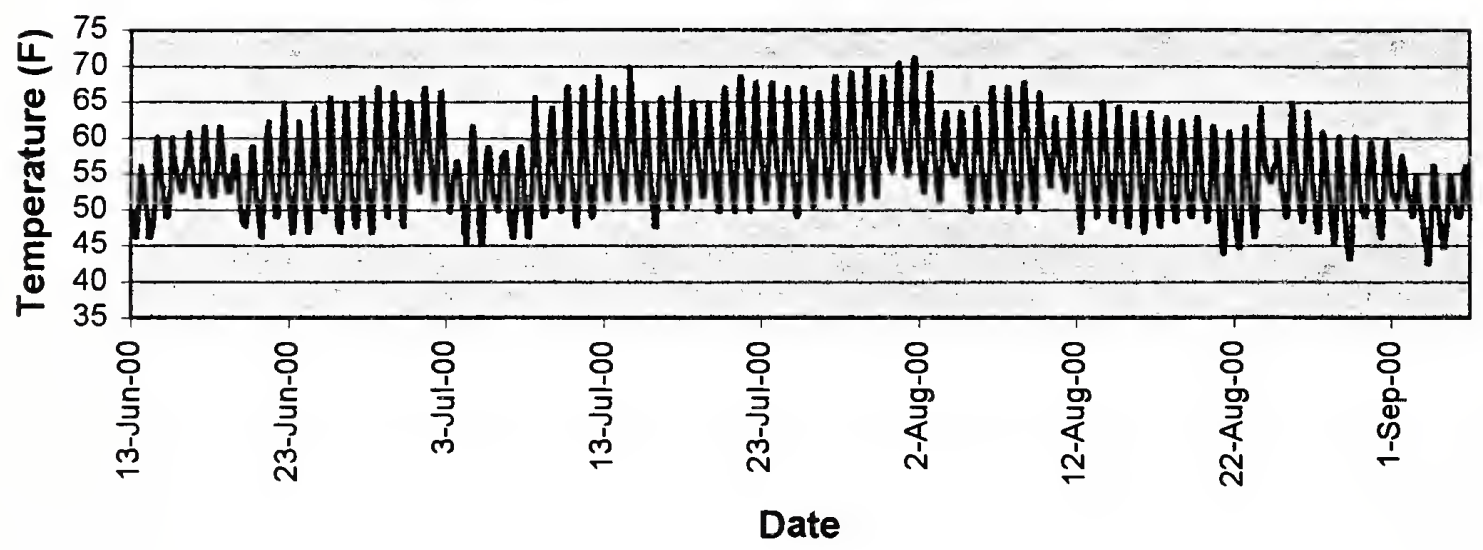

\begin{tabular}{lcccc} 
Month & June & July & August & September \\
\hline Monthly Mean & 54.6 & 57 & 55.6 & 50.4 \\
Monthly Max & 67 & 70.4 & 71.1 & 57.4 \\
Monthly Min & 46.1 & 45.4 & 43.2 & 42.5 \\
Stdev & 5.2 & 5.9 & 5.6 & 3.4
\end{tabular}

\section{Warren Creek near Mouth}

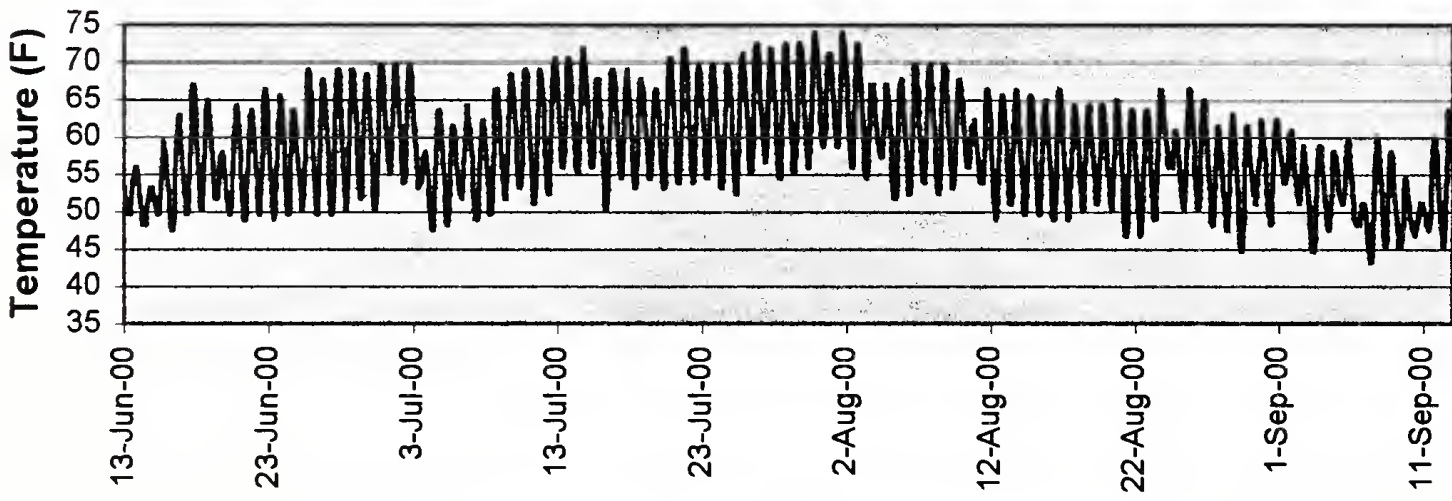

Date

\begin{tabular}{lcccc} 
Month & June & July & August & September \\
\hline Monthly Mean & 57 & 61.2 & 58.5 & 52.8 \\
Monthly Max & 69.7 & 73.8 & 73.8 & 65.6 \\
Monthly Min & 47.5 & 47.5 & 44.7 & 43.2 \\
Stdev & 6 & 6.1 & 5.8 & 4.8
\end{tabular}




\section{Wasson Creek at Hwy. 141}

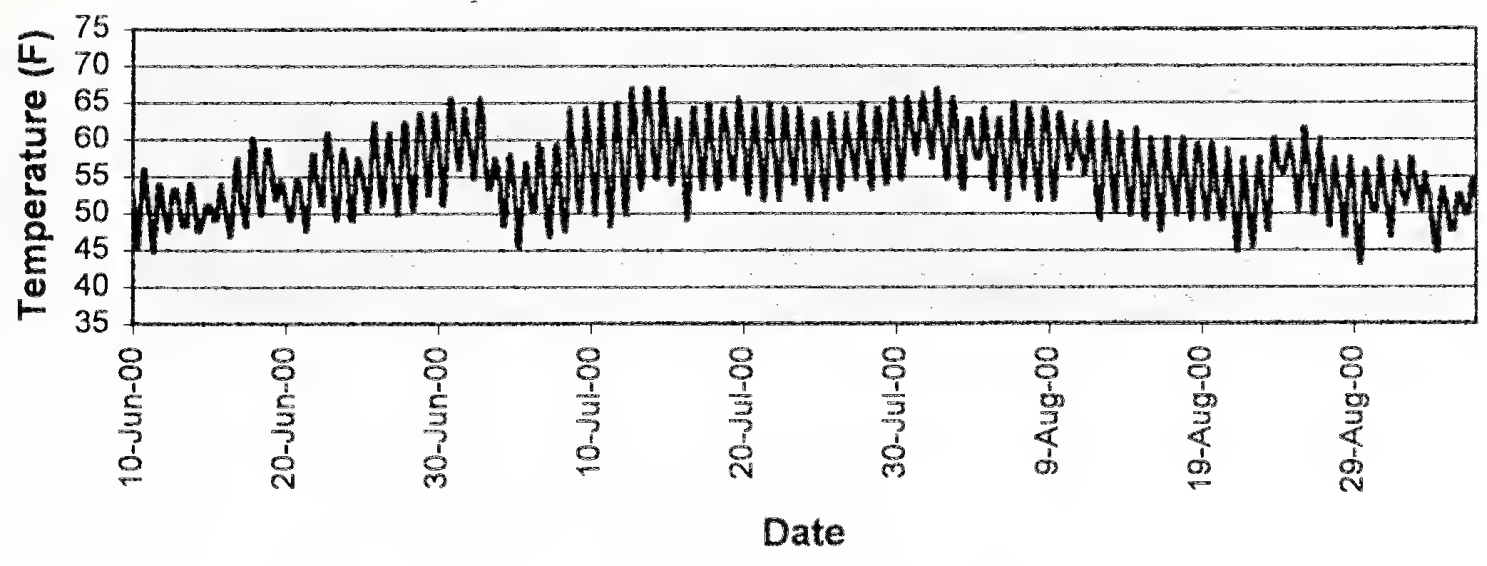

\begin{tabular}{lcccc} 
Month & June & July & August & September \\
\hline Monthly Mean & 53.6 & 57.8 & 55.7 & 51.3 \\
Monthly Max & 65.6 & 67 & 67 & 57.4 \\
Monthly Min & 44.7 & 45.4 & 43.2 & 44.7 \\
Stdev & 4.3 & 4.7 & 4.7 & 2.8
\end{tabular}

\section{Wilson Creek at Hwy. 141}

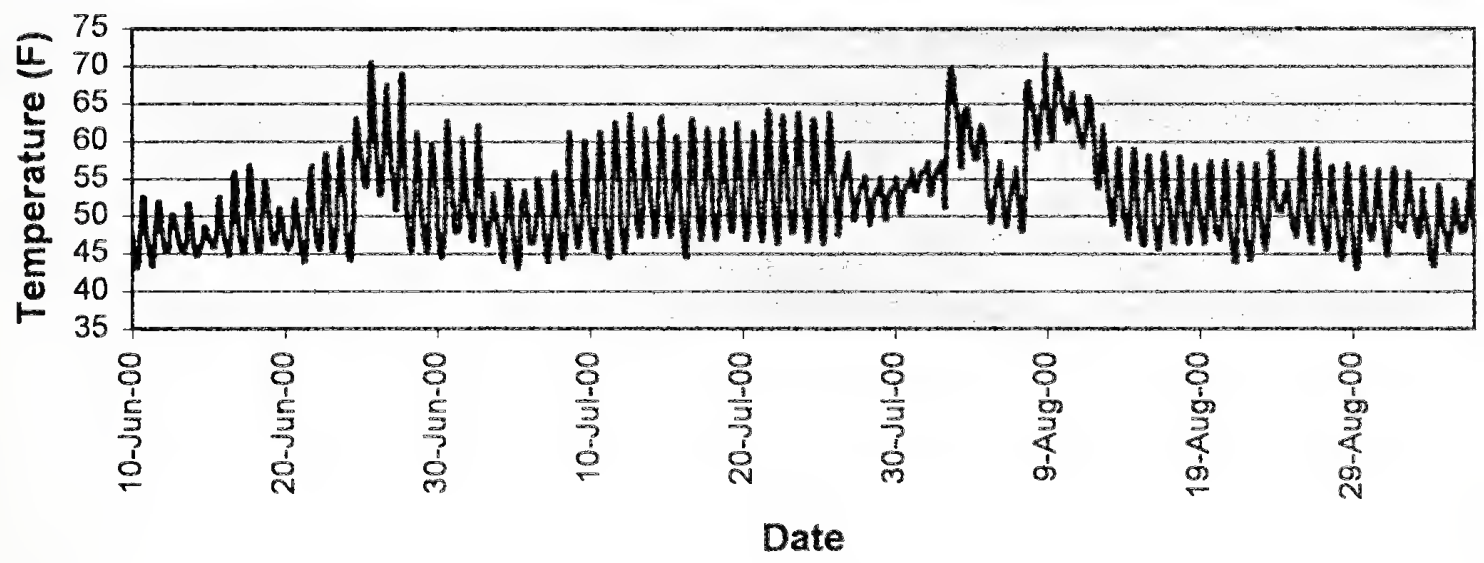

\begin{tabular}{lcccc} 
Month & June & July & August & September \\
\hline Monthly Mean & 50.8 & 52.5 & 54.3 & 49.2 \\
Monthly Max & 70.5 & 64.1 & 71.4 & 55.9 \\
Monthly Min & 43 & 43 & 43 & 43.3 \\
Stdev & 5.7 & 5 & 6.3 & 2.8
\end{tabular}




\section{Yourname Creek at Wales Cr. Road}

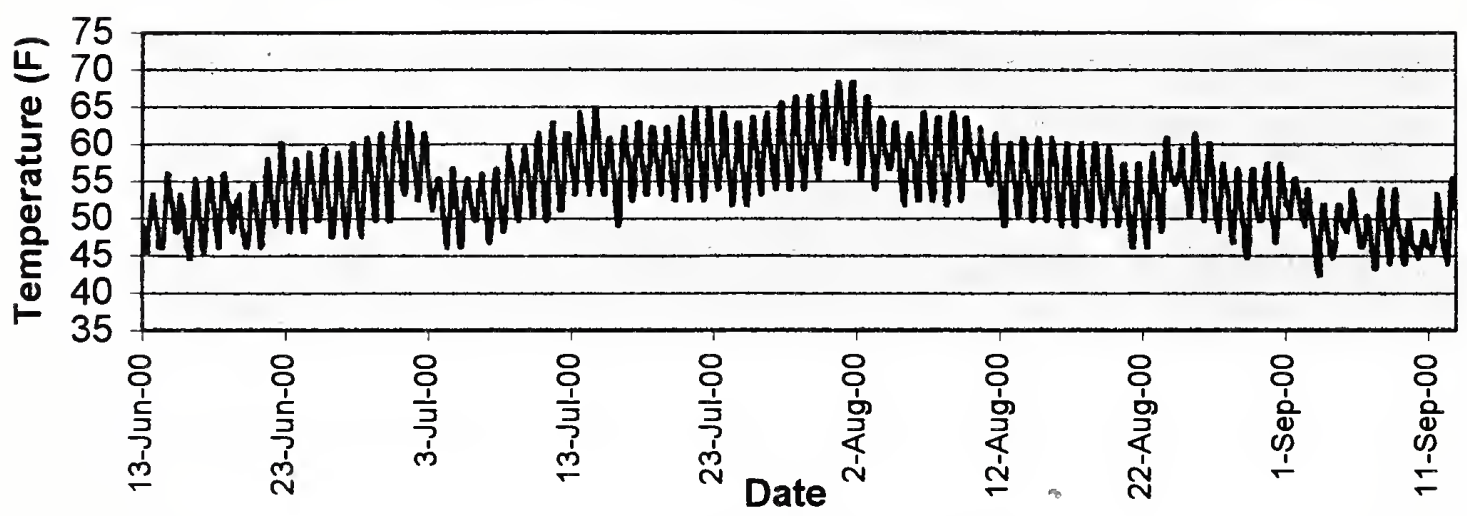

\begin{tabular}{lcccc} 
Month & June & July & August & Septemb \\
\hline Monthly Mean & 52.3 & 57 & 55.6 & 49.1 \\
Monthly Max & 62.9 & 68.3 & 68.3 & 58 \\
Monthly Min & 44.7 & 46.1 & 44.7 & 42.5 \\
Stdev & 4.2 & 4.6 & 4.6 & 3.3
\end{tabular}


2000 Granet Mountain Range Genetic Sample Summary

Exhibit K. Westslope cutthroat trout genetic sampling results

\begin{tabular}{|c|c|c|c|c|c|c|}
\hline Stream Name & Date & $\begin{array}{c}\text { Location } \\
\text { (stream mile) }\end{array}$ & $\begin{array}{l}\text { Township, Range, } \\
\text { Section }\end{array}$ & $\begin{array}{l}\text { \# Fish per } \\
\text { Sampie }\end{array}$ & \% Purity & Introgression \\
\hline Arkansas Creek & 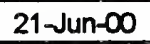 & 1.7 & $13 N, 16 W, 27 D$ & 8 & & \\
\hline Arkansas Creek & $21-J u n-\infty$ & 3 & $13 \mathrm{~N}, 16 \mathrm{~W}, 33 \mathrm{~B}$ & 13 & & \\
\hline Ashby Creek & $21-J u n-\infty$ & 1 & $13 \mathrm{~N}, 16 \mathrm{~W}, 23 \mathrm{~B}$ & 3 & & \\
\hline Ashby Creek & $16-J u n-\infty$ & 3 & $13 \mathrm{~N}, 16 \mathrm{~W}, 35 \mathrm{~B}$ & 25 & & \\
\hline Ashby Creek & $21-J u n-\infty$ & 4.8 & $12 \mathrm{~N}, 16 \mathrm{~W}, 3 \mathrm{C}$ & 8 & & \\
\hline E.F. Ashby Creek & $16-J u n-\infty$ & 0.1 & $12 N, 16 \mathrm{~W}, 3 \mathrm{D}$ & 8 & & \\
\hline Chicken Creek & $17-J u l-\infty$ & 1.2 & $12 \mathrm{~N}, 10 \mathrm{~W}, 11 \mathrm{~A}$ & 8 & & \\
\hline $\begin{array}{c}\text { Chimney Creek } \\
\text { (trib.to Douglas Cr.) }\end{array}$ & $11-J u l-\infty$ & 2.5 & $12 \mathrm{~N}, 12 \mathrm{~W}, 24 \mathrm{~A}$ & 3 & & \\
\hline $\begin{array}{c}\text { Chimney Creek } \\
\text { (trib.to Douglas } \mathrm{Cr} \text {.) }\end{array}$ & $11-J u t-\infty$ & 3.5 & $12 \mathrm{~N}, 11 \mathrm{~W}, 30 \mathrm{~B}$ & 8 & & \\
\hline $\begin{array}{c}\text { Chimney Creek } \\
\text { (trib.to Nevada Cr.) }\end{array}$ & $1-$ Aug-o & 2.2 & $13 \mathrm{~N}, 10 \mathrm{~W}, 32 \mathrm{~A}$ & 17 & & \\
\hline $\begin{array}{l}\text { Cottonwood Creek } \\
\text { (trib.to Nevada Cr.) }\end{array}$ & 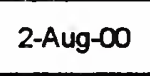 & 10.2 & $12 \mathrm{~N}, 11 \mathrm{~W}, 26 \mathrm{~A}$ & 25 & & \\
\hline Game Creek & $22-J u n-\infty$ & 1.9 & $13 \mathrm{~N}, 16 \mathrm{~W}, 20 \mathrm{~A}$ & 11 & & \\
\hline Game Creek & 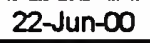 & 3.8 & $13 \mathrm{~N}, 16 \mathrm{~W}, 30 \mathrm{C}$ & 16 & & \\
\hline Murray Creek & $12-$ Jul- $\infty$ & 3.3 & $12 \mathrm{~N}, 12 \mathrm{~W}, 9 \mathrm{C}$ & 3 & $100 \%$ & \\
\hline Murray Creek & $12-J u l-\infty$ & 5.4 & $12 \mathrm{~N}, 12 \mathrm{~W}, 6 \mathrm{D}$ & 22 & $100 \%$ & \\
\hline $\begin{array}{c}\text { Smith Creek } \\
\text { (trib.to Camas } \mathrm{Cr} \text {.) }\end{array}$ & 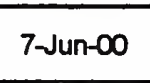 & 0.1 & $12 \mathrm{~N}, 15 \mathrm{~W}, 8 \mathrm{C}$ & 18 & & \\
\hline $\begin{array}{l}\text { Darr's Spring Creek } \\
\text { (trib.to Sturgeon Cr.) }\end{array}$ & 25-Jul-00 & 0.1 & $12 \mathrm{~N}, 12 \mathrm{~W}, 270$ & 18 & & \\
\hline Union Creek & 26-Jun- $\infty$ & 7.2 & $13 N, 16 W, 14 D$ & 9 & & \\
\hline Union Creek & $7-$ Jun- $\infty$ & 9.1 & $13 N, 16 W 13 C$ & 1 & & \\
\hline Union Creek & 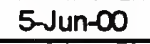 & 16.5 & $12 N, 15 W, 3 A \& D$ & 25 & & \\
\hline Wales Creek & 8-Aug-00 & 0.1 & $14 \mathrm{~N}, 12 \mathrm{~W}, 34 \mathrm{~B}$ & 3 & $100 \%$ & \\
\hline Wales Creek & 9 Aug- $\infty$ & 1.9 & $13 \mathrm{~N}, 12 \mathrm{~W}, 5 \mathrm{~B}$ & 5 & $100 \%$ & \\
\hline Wales Creek & 9-Aug-00 & 2.6 & $13 \mathrm{~N}, 12 \mathrm{~W}, 5 \mathrm{~B}$ & 17 & $100 \%$ & \\
\hline Washoe Creek & 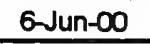 & 0.2 & $13 \mathrm{~N}, 15 \mathrm{~W}, 27 \mathrm{~B}$ & 8 & & \\
\hline Washoe Creek & 5-Jun-00 & 0.6 & $13 N, 15 W, 27 A$ & 4 & & \\
\hline Wasson Creek & $18-J u t-\infty$ & 5.2 & $13 \mathrm{~N}, 10 \mathrm{~W}, 90$ & 12 & & \\
\hline Wilson Creek & 8-Jul-00 & 2.9 & $13 \mathrm{~N}, 10 \mathrm{~W}, 16 \mathrm{C}$ & 25 & & \\
\hline Youmame Creek & 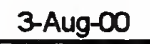 & 1.8 & $13 \mathrm{~N}, 12 \mathrm{~W}, 10 \mathrm{C}$ & 12 & $100 \%$ & \\
\hline $\begin{array}{c}\text { Company Irrigation Ditch } \\
\text { (trib.toYoumame Cr.) }\end{array}$ & 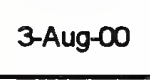 & 1.8 & $13 N, 12 W, 10 C$ & 4 & $100 \%$ & \\
\hline Youmame Creek & 3-Aug-00 & 4.6 & $13 \mathrm{~N}, 12 \mathrm{~W}, 18 \mathrm{~A}$ & 9 & $100 \%$ & \\
\hline
\end{tabular}


March 20, 2001

Ladd Knotek

Genetics Contact, Region 2

Montana Fish, Wildlife \& Parks

3201 Spurgin Road

Missoula, MT 59801

Ladd:

We have completed analysis of the following samples:

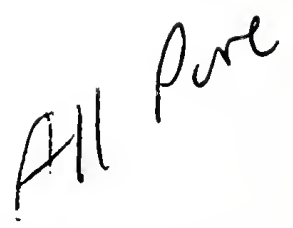

Table 1 . Summary of results.

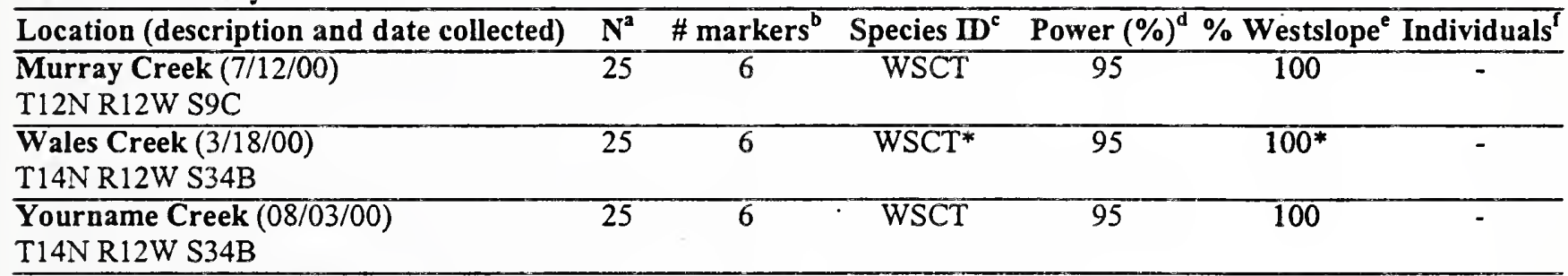

"Number of samples analyzed; if combined with previous sample (indicated in "Location" column), number indicates the combined sample size; if present, the number in 0 is the average number successfully analyzed per locus (some individuals do not amplify for all marker loci).

${ }^{b}$ Number of markers analyzed that are diagnostic for the non-native species.

${ }^{\circ}$ Codes: WSCT $=$ westslope cutthroat trout (Oncorhynchus clarki lewisi); RBT= rainbow trout $(O$. mykiss); YSCT= Yellowstone cutthroat trout $(O$. clarki bouvieri). Only one species code is listed when the entire sample possessed alleles from that species only. However, it must be noted that in such cases we cannot definitively rule out the possibility that some or all of the individuals are hybrids; we merely have not detected any non-native alleles at the limited number of loci examined (see Power \% column). Species codes separated by " $x$ " indicate hybridization between those species.

${ }^{d}$ Number corresponds to the percent chance we have to detect $1 \%$ hybridization given the number of individuals successfully analyzed and the number of diagnostic markers used (e.g., 25 individuals are required to yield a $95 \%$ chance to detect $1 \%$ hybridization of rainbow or Yellowstone cutthroat trout into a westslope trout population using the 6 available markers). Not reported when hybridization is detected.

'Indicates the genetic contribution of westslope cutthroat trout to the sample assuming Hardy-Weinberg proportions. This number is reported only if samples appear to come from a randomly mating population and can be analyzed at the population level. 'Indicates number of individuals with genotypes corresponding to the species code column when the sample can be analyzed on the individual level only; this occurs when alleles are not randomly distributed and hybridization appears to be recent and/or if the sample appears to consist of an admixture of populations.

"See the "Sample Details" section below. 


\section{Brief Description of Methods:}

Polymerase chain reaction (PCR) amplification of paired interspersed nuclear DNA elements (PINEs) was used to determine each fish's genetic characteristics at multiple regions of the nuclear DNA. This method produces DNA fragments that can be used to distinguish between various cutthroat trout subspecies (Oncorhynchus clarki spp.), rainbow trout (O. mykiss) and their hybrids, and between bull trout (Salvelinus confluentus), brook trout ( $S$. fontinalis), and their hybrids. The presence of a PINE marker is dominant to absence. First-generation $\left(F_{1}\right)$ hybrids will have all the diagnostic markers characteristic of the two hybridizing species. Backcrossed individuals will possess some, but not all, markers characteristic of both parental species. The appearance of a marker indicates the individual is either heterozygous or homozygous for that marker, which precludes us from directly calculating allele frequencies.

Unless the distribution of markers dictates otherwise, we assume the samples conform to random mating expectations in order to estimate the average genetic contribution from each species. In these cases, we report the percent genetic contribution from each species present in the population. When hybridization is present in these situations, the population is considered a hybrid swarm. Regardless of the percent contribution from the non-native species, in hybrid swarms, all individuals are of hybrid origin, even those that appear "pure" at our diagnostic loci. It is not possible to rescue pure individuals from these populations, as they likely do not exist. Due to the random reshuffling of alleles during sexual reproduction, many individuals will appear pure for one or the other parental species due to the limited number of marker loci used. It has been shown that 6 markers are adequate to provide coarse classification of hybridization, but upwards of 70 markers are required to discriminate between pure individuals, if they exist, and backcrossed individuals in hybrid swarms (Boecklen and Howard 1997).

However, when the distribution of non-native markers appears to be non-random, it is not valid to report genetic contributions of the component species at the population level, as they do not come from a randomly mating population. It is likely that the individuals in these samples either come from populations where hybridization is recent or are from admixtures of populations. Samples can be analyzed at the individual level only. These samples are not considered to come from hybrid swarms and some pure individuals may exist. In these cases, we report the number of individuals with genotypes corresponding to each species and/or the types of hybrids detected and do not report genetic contribution percentages.

Literature Cited:

Boecklen WJ, and Howard DJ (1997) Genetic analysis of hybrid zones: numbers of markers and power of resolution. Ecology 78 (8) pp. 2611-2616. 


\section{Sample Details:}

Murray Creek: The 25 individuals in this collection exhibited PINE markers indicative of westslope cutthroat trout (Oncorhynchus clarki lewisi) only. With a sample size of 25 , we had a $95 \%$ chance to detect as little as $1 \%$ hybridization. This collection appeared to come from a pure westslope cutthroat trout population.

Wales Creek: Twenty-four of the 25 individuals in this collection exhibited PINE markers indicative of westslope cutthroat trout (Oncorhynchus clarki lewisi) only. One individual exhibited one marker indicative of rainbow trout (O. mykiss). However, regional variation at this marker within pure westslope cutthroat trout populations is sometimes indistinguishable electrophoretically from that exhibited by rainbow trout. Furthermore, given that this was the only potential rainbow marker exhibited in this entire sample, we cautiously conclude that this collection was from a pure westslope cutthroat trout population. With a sample size of 25 , we had a $95 \%$ chance to detect as little as $1 \%$ hybridization.

Yourname Creek: The 25 individuals in this collection exhibited PINE markers indicative of westslope cutthroat trout (Oncorhynchus clarki lewisi) only. With a sample size of 25 , we had a $95 \%$ chance to detect as little as $1 \%$ hybridization. This collection appeared to come from a pure westslope cutthroat trout population.

Sincerely,

John K. Wenburg

Cc: Steve Carson (electronic version) 


